$\Psi$ Universidade de Brasília

Departamento de Design

Programa de Pós-Graduação em Design

MARJORIE AMY YAMADA

FALANDO EM QUADRINHOS:

A influência do letreiramento nas histórias em quadrinhos 
MARJORIE AMY YAMADA

FALANDO EM QUADRINHOS:

A influência do letreiramento nas histórias em quadrinhos

Dissertação de mestrado apresentada ao programa de Pós-Graduação em Design da Universidade de Brasília para obtenção do título Mestra em Design, na área de concentração de Design, Tecnologia e Sociedade, sob orientação do Prof. Dr. Luiz Fernando Luzzi Las-Casas.

Brasília 
Ficha catalográfica

Biblioteca Central da Universidade de Brasília

Yamada, Marjorie

Y11f Falando em quadrinhos: a influência do

letreiramento nas histórias em quadrinhos / Marjorie

Yamada; orientador Luiz Fernando Las-Casas. --

Brasilia, 2015.

$190 \mathrm{p}$.

Dissertação (Mestrado - Mestrado em Design) - Universidade de Brasilia, 2015.

1. história em quadrinhos. 2. letreiramento. 3. diagramação. 4. design gráfico. I. Las-Casas, Luiz Fernando, orient. II. Título. 


\title{
FALANDO EM QUADRINHOS: A INFLUÊNCIA DO LETREIRAMENTO NAS HISTÓRIAS EM QUADRINHOS
}

\author{
Marjorie Amy Yamada
}

Dissertação submetida ao Programa de Pós-Graduação em Design do Instituto de - Artes da Universidade de Brasília como parte dos requisitos para a obtenção do grau de Mestre em Design.

Aprovada por:

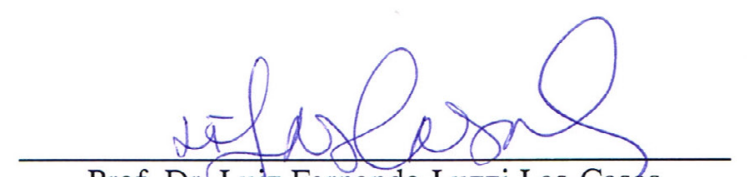

Prof. Dr. Luiz Fernando Luzzi Las-Casás

$\mathrm{IdA} / \mathrm{DIn} / \mathrm{UnB}$
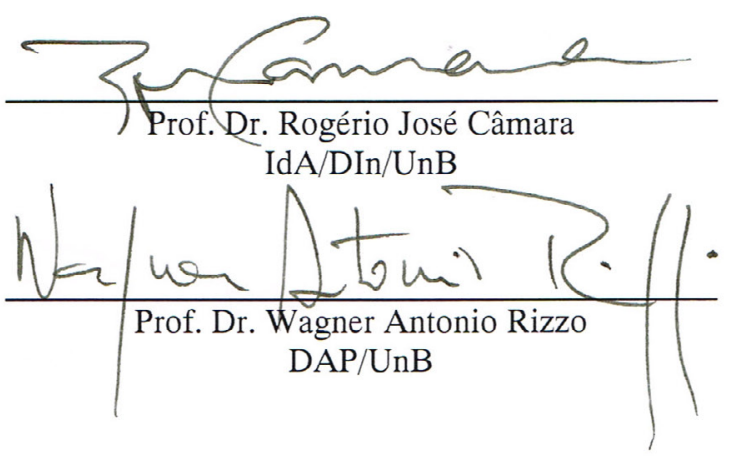

Brasília-DF, 15 de Julho de 2015

Coordenação de Pós-Graduação em Design do Departamento de Desenho Industrial Instituto de Artes /UnB 


\section{AGRADECIMENTOS}

Primeiramente, à minha família, que, durante todo o processo, me apoiou, confiou em mim e me ajudou a manter tranquilidade e segurança.

Ao orientador Luiz Fernando Las-Casas, ou Nanche, de quem recebi válidos puxões de orelha, com quem troquei histórias e discussões sobre HQs.

À professora Claudete Ruas, pela compreensão e por me orientar informalmente a respeito das análises estatísticas.

Ao professor Rogério Camara e ao professor Wagner Rizzo, por participarem da minha qualificação e da minha defesa e trazerem complementação pertinente para a pesquisa.

Ao André Reis, ao Vinícius de Azevedo e ao Rafael Benjamin, que contribuíram com a elaboração da pesquisa e fizeram com que, independente do letreiramento, a maioria dos participantes tivesse opiniões positivas sobre a história fictícia.

Ao Troy Peteri, ao Todd Klein, à Lilian Mitsunaga, ao Nate Piekos, ao Ron Marz e ao Sidney Gusman, que, apesar de suas agendas atribuladas, dedicaram tempo para responder às questões enviadas e enriqueceram meu trabalho.

Ao Cássio Filho, por acompanhar cada passo desse trajeto, por me lembrar das horas das refeições e por me encorajar quando o computador subitamente apagava sem salvar meus arquivos.

Aos meus amigos, que me deram suporte, emprestaram quadrinhos e opiniões, divulgaram a pesquisa, me mostraram todo artigo que julgavam importante e fizeram valer o "se precisar, é só falar".

A todos que responderam o questionário.

Muito obrigada! 
"This was the year I discovered the excitement of 'marrying' words to pictures. I began to get it through my skull that words and pictures were Yin and Yang. I began thinking that words and pictures, married, might possibly produce a progeny more interesting than either parent."

(Theodor Seuss Geisel) 


\section{RESUMO}

Possuidora de uma linguagem própria, a história em quadrinhos é uma mídia que integra o mundo das palavras e o mundo das imagens. Uma particularidades que contribui para reforçar essa relação é a exploração de propriedades gráficas das letras para a inserção harmoniosa na ilustração e para sugerir a transmissão de sons de forma mais precisa. O objeto de estudo deste trabalho consiste no planejamento e no emprego do texto nos quadrinhos, etapa chamada de letreiramento. Para contextualizar o processo, é apresentado um panorama histórico da evolução da diagramação textual no universo dos quadrinhos, acompanhando desde as obras precursoras das primeiras tiras cômicas até os preceitos atuais para a produção da nona arte. Em seguida, por meio de revisão de literatura e estudos de caso, descreve-se cada uma das incumbências dessa etapa, com explicação das diretrizes normalmente utilizadas. A fim de esclarecer aspectos da profissão do letreirista, alguns profissionais envolvidos na produção de histórias em quadrinhos responderam cerca de dez questões sobre o assunto. As respostas são apresentadas separadamente e, para os casos de diferentes pontos de vista, são analisadas em conjunto. Por fim, para compreender a percepção do leitor, apresenta-se a pesquisa realizada com o nicho de compradores de $\mathrm{HQs}$, na qual os participantes foram divididos em dois grupos, sendo que apenas um foi exposto a erros amadores de letreiramento e ambos responderam às mesmas questões. Por meio de análise descritiva e testes estatísticos de correlação, avalia-se as discrepâncias existentes e a intensidade da associação com a variável letreiramento, com a conclusão de que existe influência sobre a maneira que o leitor percebe a história.

Palavras-chave: história em quadrinhos, letreiramento, diagramação, design gráfico 


\begin{abstract}
With its own language, comics are a medium that integrates the world of words and the world of images. A feature that helps to strengthen this relationship is the exploration of text graphic properties for harmonious insertion in the illustration and to suggest the transmission of sounds more precisely. The study object of this work consists in planning and inserting text in comics, a step called comic lettering. To contextualize the process, a historical overview of the evolution of textual layout in the world of comics is presented, following from the precursor works of the first comic strips to current concepts for the ninth art production. Then, through literature review and case studies, it is described each of the tasks of this phase, with an explanation of the guidelines commonly used. In order to clarify aspects of comic letterer profession, some professionals involved in the production of comics responded about ten questions on the subject. The answers are presented separately and, for cases of different points of view, they are analyzed together. Finally, to understand the perception of the reader, it is showed the survey conducted among the niche of comic book buyers, in which participants were divided into two groups: only one of which was exposed to lettering amateurs error and both were asked the same questions. Through descriptive analysis and statistical correlation tests, the discrepancies are evaluated and so is the intensity of association with variable of comic lettering, with the conclusion that there is influence over the way that the reader perceives the story.
\end{abstract}

Keywords: comics, comic lettering, layout, graphic design 


\section{LISTA DE FIGURAS}

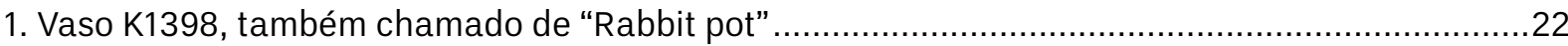

2. Bois Protat, a xilografia mais antiga remanescente do Ocidente, criada entre 1370 e $1380 \ldots \ldots . . .23$

3. Osterspiel, de cerca de 1500, retrata uma peça de teatro medieval com o personagem segu-

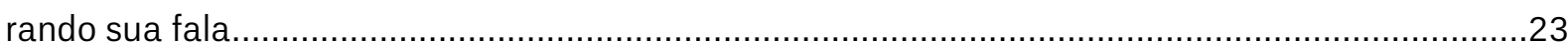

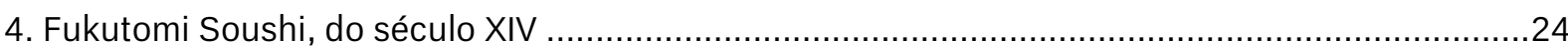

5. A true narrative of the horrid hellish Popish Plot, de Francis Barlow, 1682 …...............................25

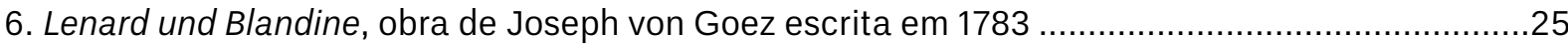

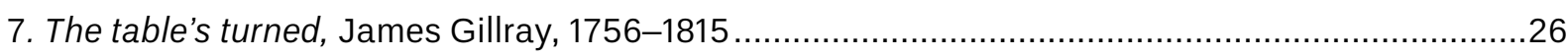

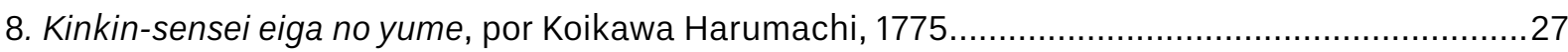

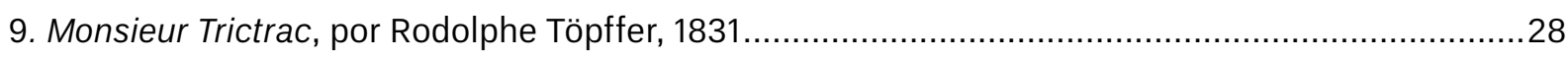

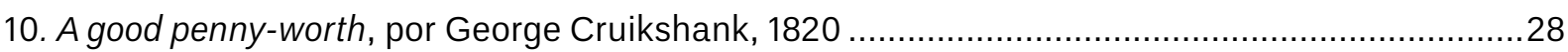

11. Quadro de McLean's monthly sheet of caricatures No. 14 - or The Original Looking Glass, por

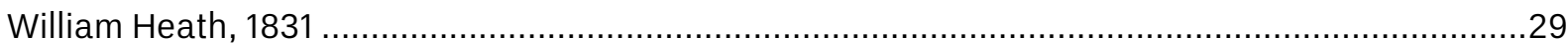

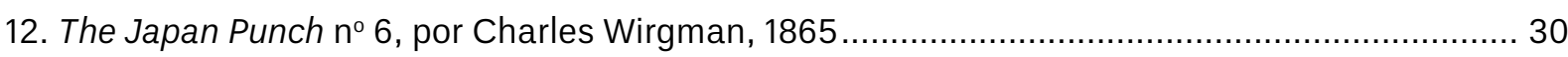

13. As aventuras de Nhô Quim, por Angelo Agostini, 1869......................................................... 31

14. The Yellow Kid and his new phonograph, por Richard Outcault, 1896 ......................................32

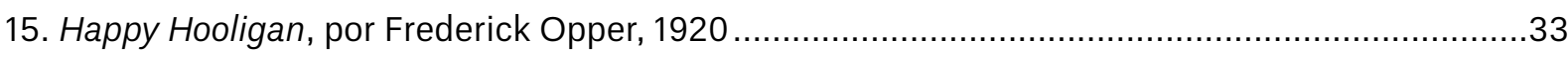

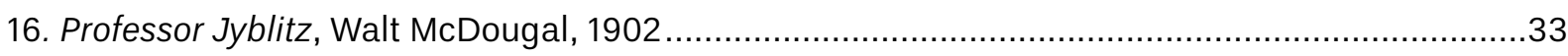

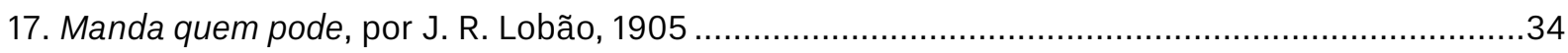

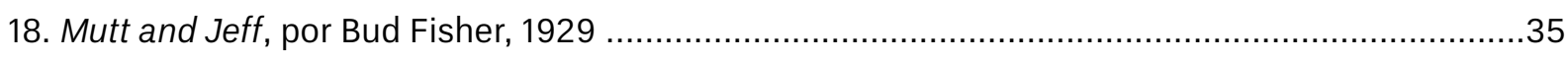

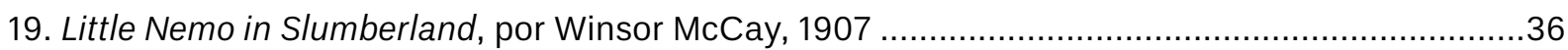

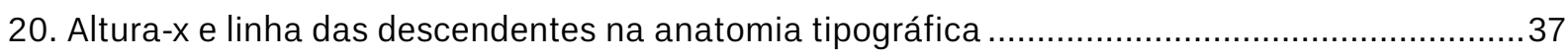

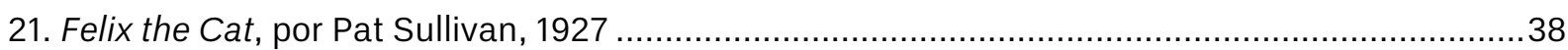

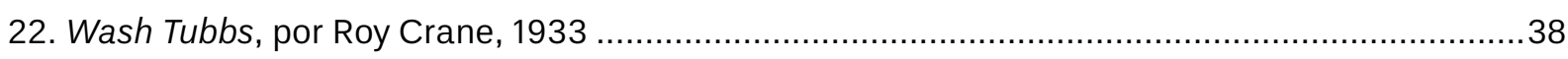

23. O camondongo Mickey, por Walt Disney, editado por O Tico-Tico, 1937 ......................................39

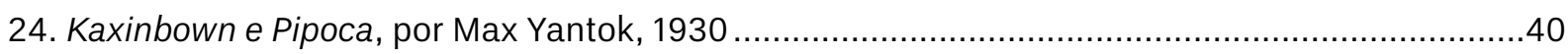

25. Versão light da fonte tipográfica Cartoon, criada por Howard Trafton, 1936 ............................. 41

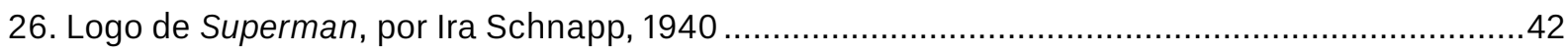

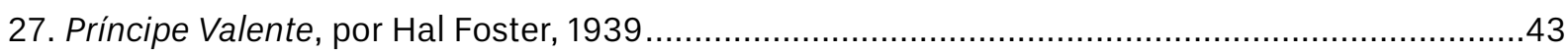

28. Representações de pensamento em Superman, em 1943 .........................................................44

29. Suspiro ladeado por traços curtos em Wildman, por Bill Finger e Irwin Hasen, em 1942 ...........44

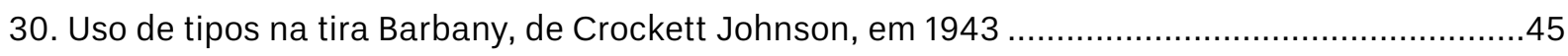

31. Página de abertura de The Spirit, por Will Eisner, 1950.............................................................46

32. Uso de balão em Shin Takarajima, por Osamu Tezuka, 1946 .....................................................48

33. Uso de onomatopeia em Shin Takarajima, por Osamu Tezuka, 1946 ........................................49

34. Adaptação de O Guarani, por André LeBlanc, 1950 ............................................................ 50

35. Exemplo da fala de P. T. Bridgeport, personagem de Pogo, por Walt Kelly, 1948-1975............... 50

36. Uso do letreiramento Leroy em Wonder Woman, escrito por Charles Moulton, 1944.................. 51

37. Títulos inseridos por Typositor e créditos à esquerda para "A. Machine" .....................................52

38. Uso de máquina fotocompositora para textos em balões .......................................................53 
39. Jesse James após revisão do Código, por Everett Raymond Kinstler, 1955 ...............................54

40. Sequência de cenas do episódio The Bird's Last Jest da série Batman, 1966 ...............................55

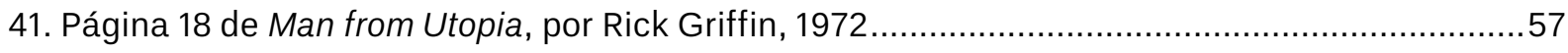

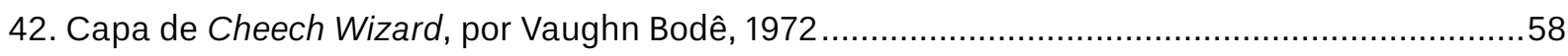

43. A contract with God and other tenement stories, por Will Eisner, 1978 .....................................59

44. Blackmark, ilustrado por Gil Kane e escrito por Archie Goodwin ...........................................60

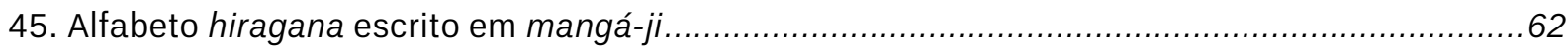

46. Primeira página de Batman: Digital Justice, por Pepe Moreno, 1990 .......................................63

47. Fonte Comics Sans, desenvolvida em 1994 por Vincent Connare ............................................64

48. Tirinha produzida pelo aplicativo Bitstrips, pela usuária Nolimity ...........................................65

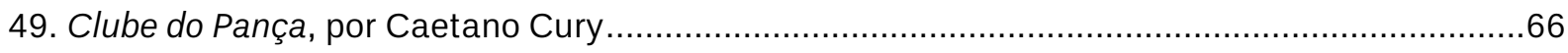

50. Tirinha com balões tradicionais no primeiro quadro e o segundo apenas com o rabicho............ 71

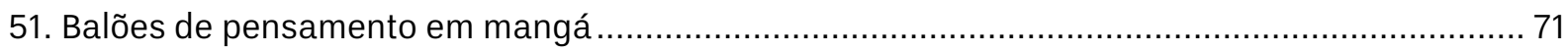

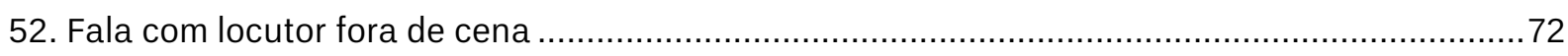

53. Uso de balão de susssuros, balão de grito e balão de pensamento ………...............................73

54. Desenho do balão salientando a frieza do personagem …….............................................

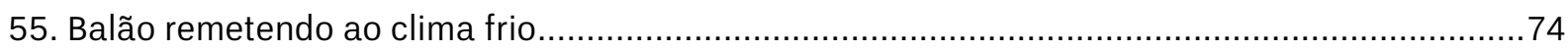

56. Uso de diferentes balões para acrescentar humor à história................................................74

57. O personagem Sonho ganha voz diferenciada através do balão de fala ....................................75

58. Uso de balão diferenciado para distinguir emissores............................................................

59. Balão de fala tratado como balão de látex, por Brian McLachlan, 2012 …..................................76

60. Parte de tira usando metaquadrinhos, por Alex Norris, 2013 .................................................77

61. Balão parcialmente oculto em Daredevil n 26, por Mark Waid e Chris Samnee, 2013 …............77

62. Diferentes tipos de anúncios: retangular, dentado e com sombra. ..........................................78

63. Anúncio em história em quadrinhos, por Ira Schnapp, 1962 .................................................78

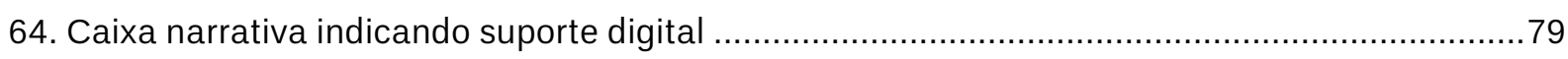

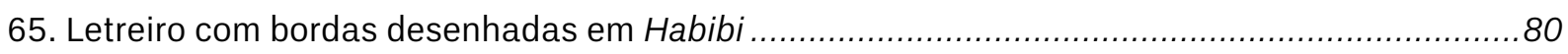

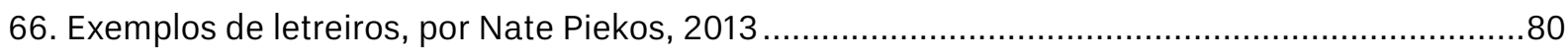

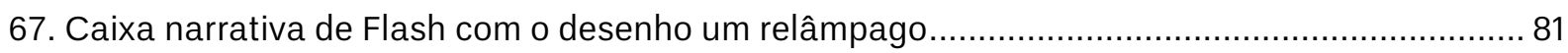

68. Texto posto por cima da ilustração em Rurouni Kenshin, por Nobuhiro Watsuki, 1994 ...............82

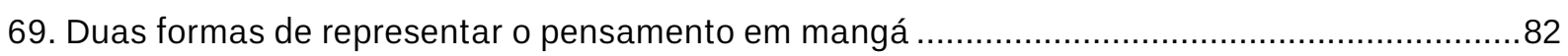

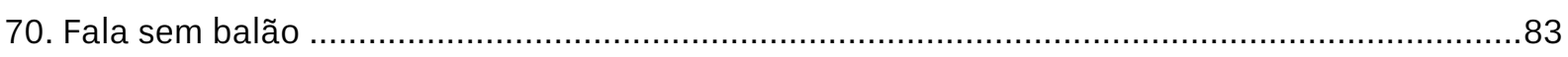

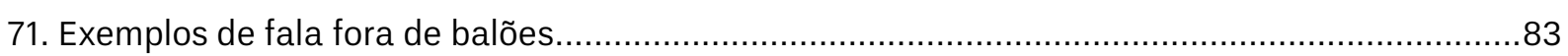

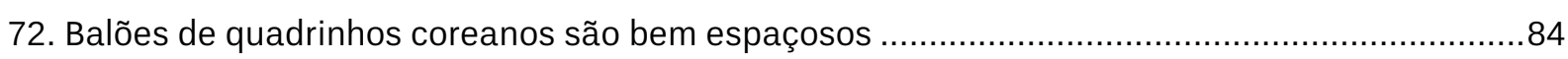

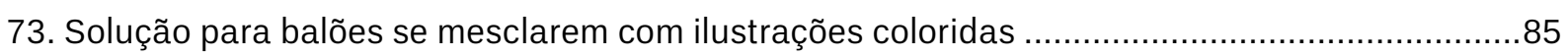

74. Representação da passagem do tempo como uma corda pelos balões de fala ...........................86

75. Comparação das tiras em quadrinhos com outras formas de expressão....................................87

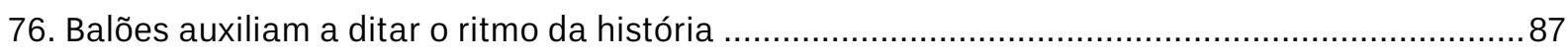

77. Exemplo de orientação de leitura através dos balões ................................................................ 88

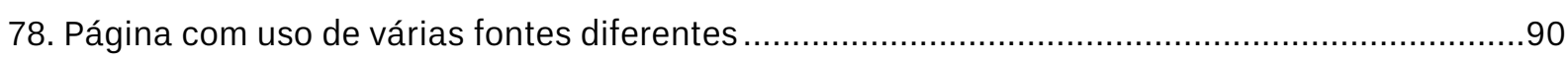

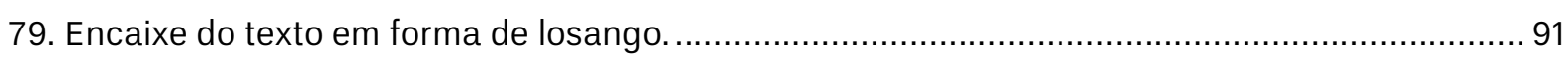

80. A escrita coreana é em linhas horizontais, da esquerda para a direita, com espaço entre pa- 


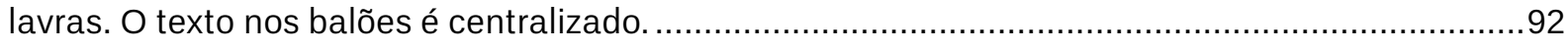

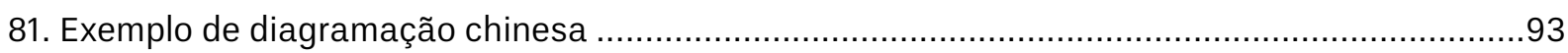

82. Formatação do texto em balões nos quadrinhos japoneses ..................................................94

83. Justificativa de Stan Lee para o nome de Spider-Man, 2010 ..................................................95

84. Espacejamento maior para demarcar estrofes em Romeo and Juliet ......................................95

85. Escrita em hiragana, kanji e furigana para a mesma palavra, "mangá" ...................................96

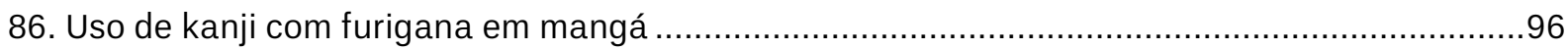

87. Grito pulando para fora do balão causam impacto de exaltação e angústia ...............................97

88. No letreiro, a interjeição de soluço, “hic”, aparece em itálico....................................................98

89. Letreiramento realça a personalidade de Delírio.....................................................................99

90. Fonte de tema tecnológico usada para a fala do Homem de Ferro ....................................... 100

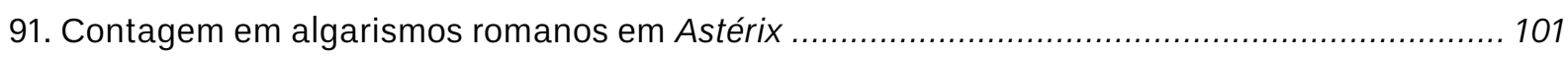

92. Shroeder cantando a Sinfonia ${ }^{\circ} 9$ de Beethoven, em letras góticas ......................................101

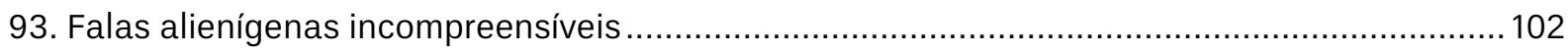

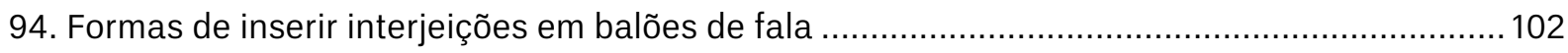

95. Interferência estática representada por arte abstrata ............................................................... 103

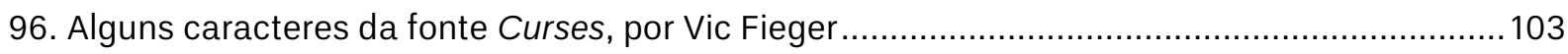

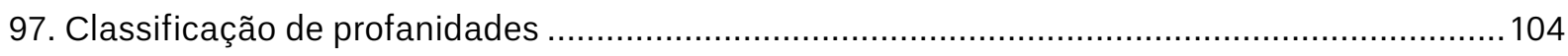

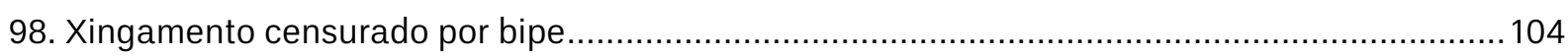

99. A perspectiva da onomatopeia colabora para dar profundidade ao ambiente. ....................... 105

100. Disposição das letras podem reforçar a ideia de movimento. ................................................. 106

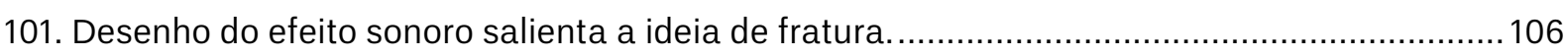

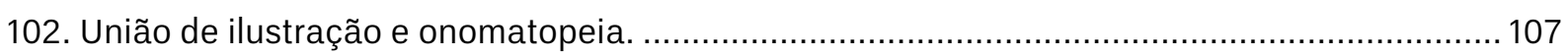

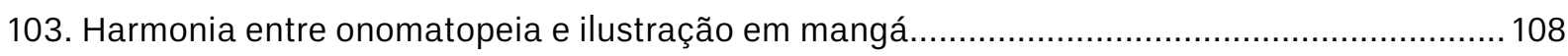

104. Quadros delimitados pela forma de onomatopeia ............................................................. 109

105. Barulho da chuva se manifesta com tanta persistência que possui até sombra......................110

106. Título em concreto, desenhado por Jim Steranko em 1968................................................... 111

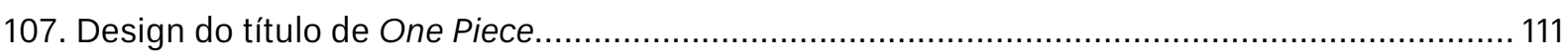

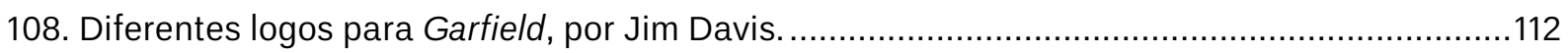

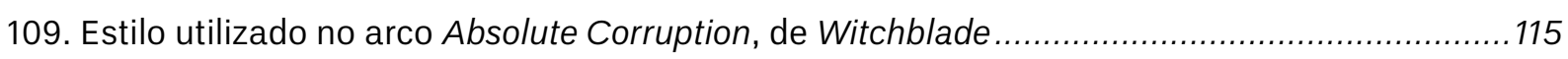

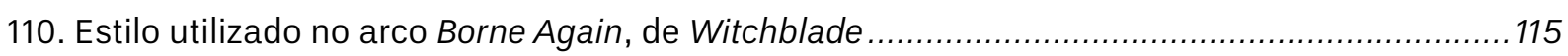

111. Letreiramento feito em papel vegetal sobre fotocópia da arte .................................................117

112. Letreiramento para o(a) personagem Desejo, em Estação das Brumas......................................118

113. Nome da letreirista Lilian junto aos criadores gringos, em Batman ....................................... 120

114. Página em que foi necessário desenhar letras em programa digital........................................ 122

115. Letreiramento por Lilian Mitsunaga em obra traduzida de Will Eisner ...................................... 123

116. Versão original da obra de Will Eisner ............................................................................. 123

117. Trecho do roteiro para a parte um de Brain Boy \#1: PSY vs. PSY, escrito por Fred Van Lente,

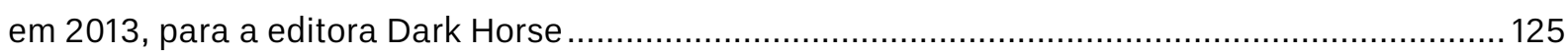

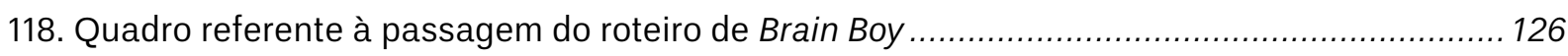

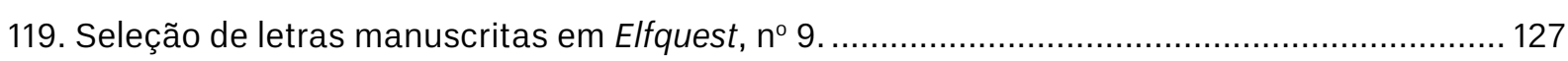

120. Trecho do roteiro de Shinku, número 7, página 2, escrito por Ron Marz.................................. 129 
121. Versão original e versão traduzida de Zap Comix.

122. Cinco erros comuns cometidos por letreiristas amadores .................................................... 133

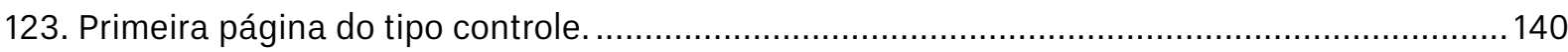

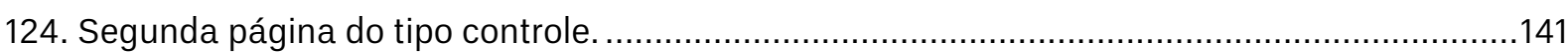

125. Fonte Clairvoyant, escolhida para as narrações em primeira pessoa........................................ 142

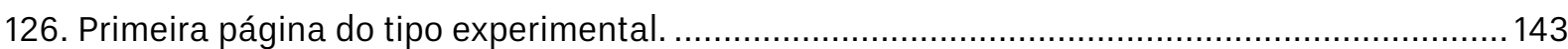

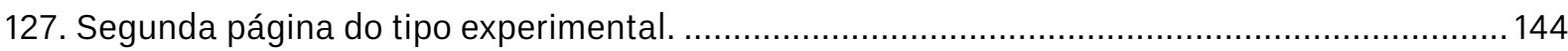

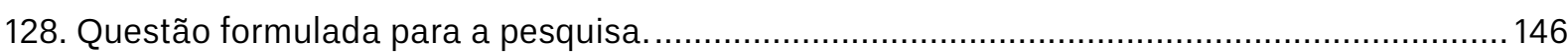

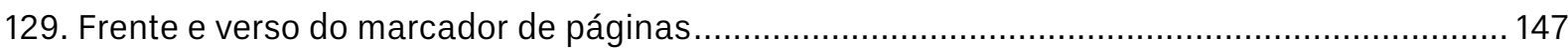

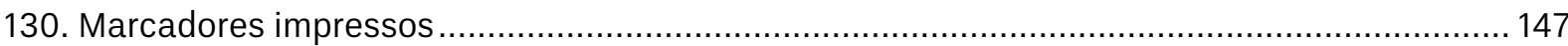




\section{LISTA DE TABELAS}

131. Distribuição conjunta das proporções de participantes segundo o grupo e o grau de concordância para a afirmação "Eu gostaria de continuar lendo".

132. Distribuição simplificada das proporções de participantes segundo o grupo e a concordância para a afirmação "Eu gostaria de continuar lendo"

133. Distribuição conjunta das proporções de participantes segundo o grupo e o grau de concordância para a afirmação "O personagem principal é interessante".

134. Distribuição simplificada das proporções de participantes segundo o grupo e a concordância para a afirmação "O personagem principal é interessante"

135. Distribuição conjunta das proporções de participantes segundo o grupo e o grau de concordância para a afirmação "A leitura é agradável"

136. Distribuição simplificada das proporções de participantes segundo o grupo e a concordância para a afirmação "A leitura é agradável"

137. Distribuição conjunta das proporções de participantes segundo o grupo e o grau de concordância para a afirmação "O texto tem boa leiturabilidade, ou seja, não exige esforço para ler".... 155 138. Distribuição simplificada das proporções de participantes segundo o grupo e a concordância para a afirmação "O texto tem boa leiturabilidade, ou seja, não exige esforço para ler". 156 139. Distribuição conjunta das proporções de participantes segundo o grupo e o grau de concordância para a afirmação "A história é confusa"

140. Distribuição simplificada das proporções de participantes segundo o grupo e a concordância para a afirmação "A história é confusa" 158

141. Distribuição conjunta das proporções de participantes segundo o grupo e o grau de concordância para a afirmação "O ritmo da narrativa é lento". 158

142. Distribuição simplificada das proporções de participantes segundo o grupo e a concordância para a afirmação "O ritmo da narrativa é lento". 159

143. Distribuição conjunta das proporções de participantes segundo o grupo e o grau de concordância para a afirmação "A equipe que fez essa história parece profissional". 160 144. Distribuição simplificada das proporções de participantes segundo o grupo e a concordância para a afirmação "A equipe que fez essa história parece profissional" 


\section{SUMÁRIO}

1 INTRODUÇÃO .......................................................................................... 15

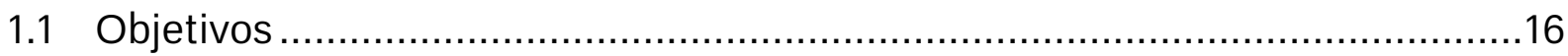

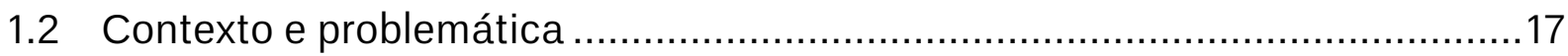

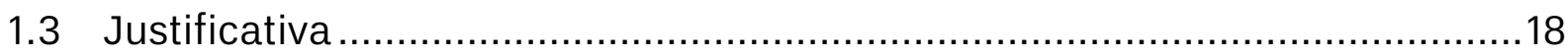

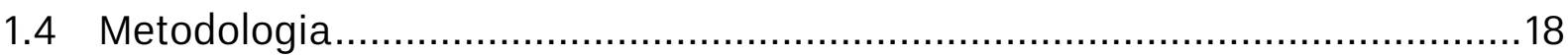

2 A TRAJETÓRIA DO LETREIRAMENTO.................................................... 21

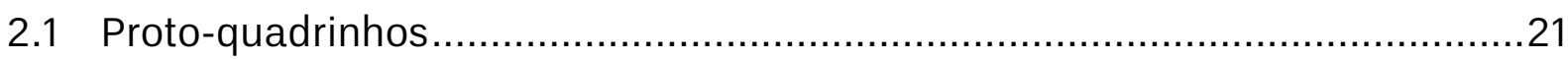

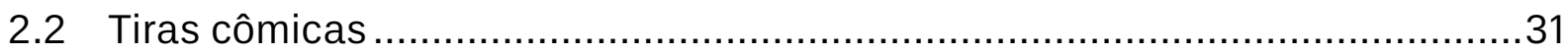

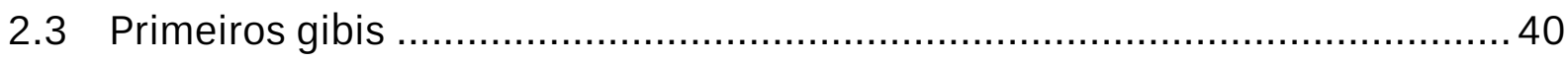

2.4 Boom mundial dos quadrinhos...................................................... 48

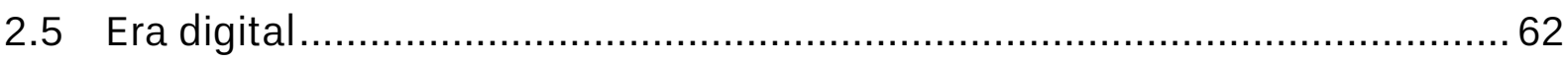

3 LETREIRANDO .....................................................................................68

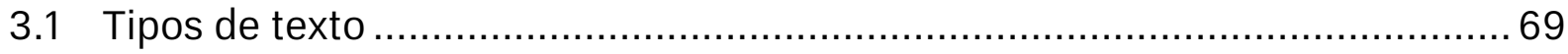

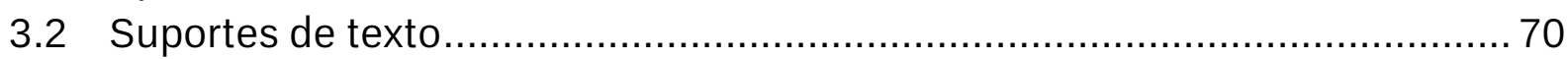

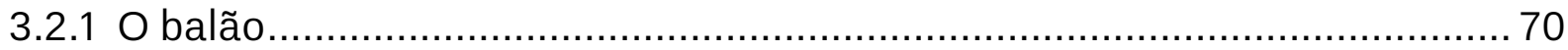

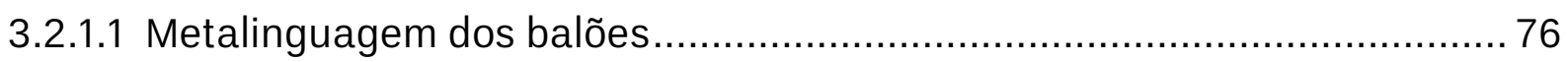

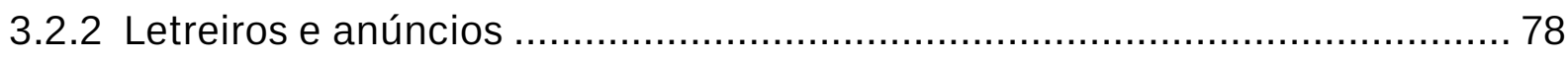

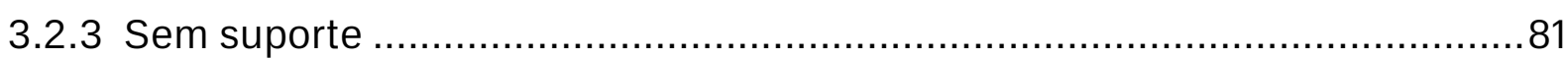

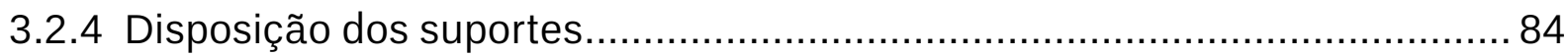

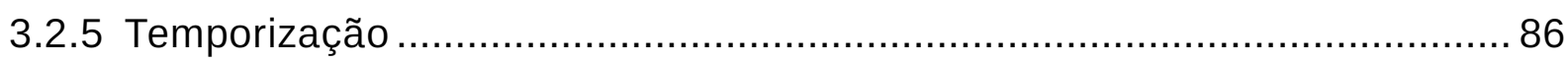

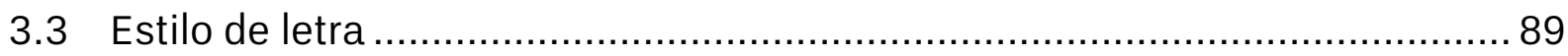

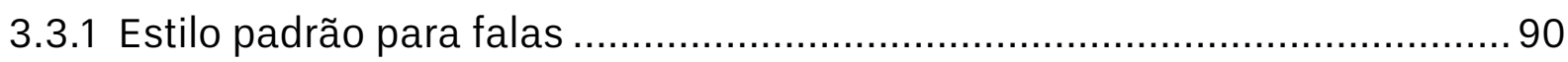

3.3.1.1 Formatação do texto................................................................ 91

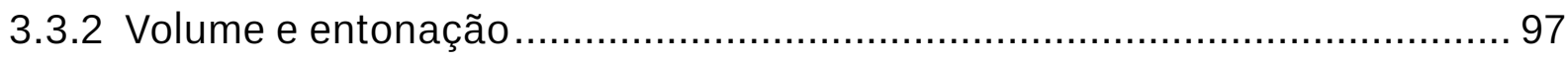

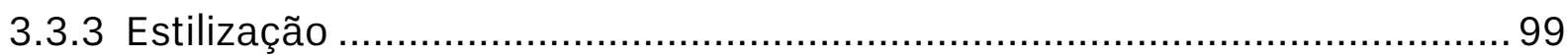

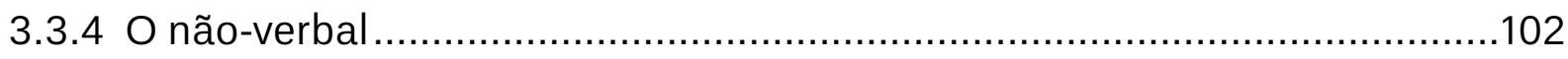

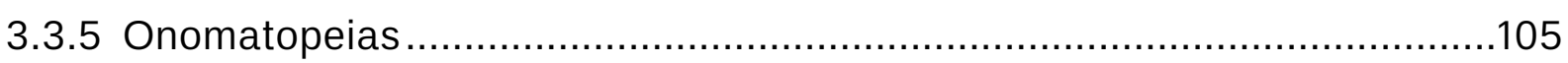

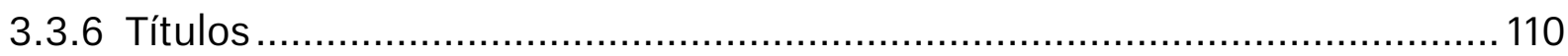

4 LETREIRAMENTO DE ACORDO COM OS PROFISSIONAIS ......................113

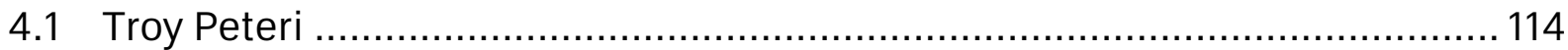

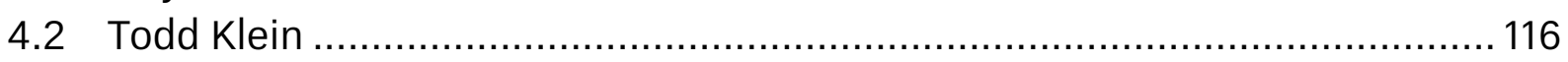

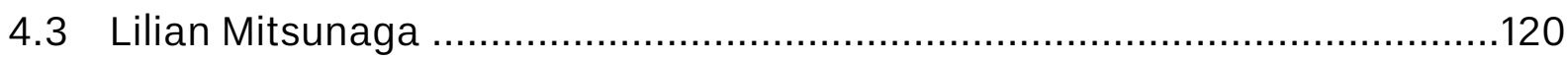

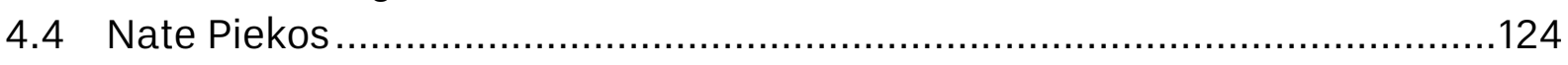

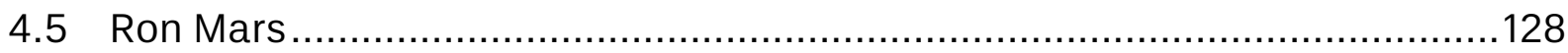

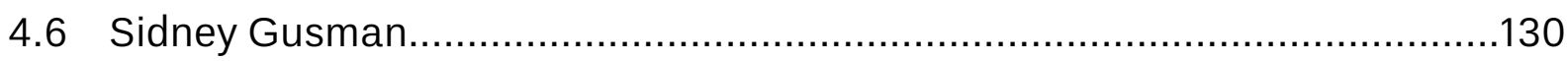

4.7 Letreiramento eficiente $\times$ Letreiramento amador .................................132

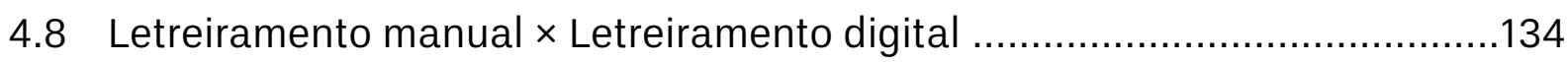




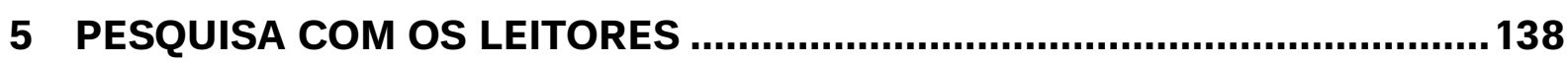

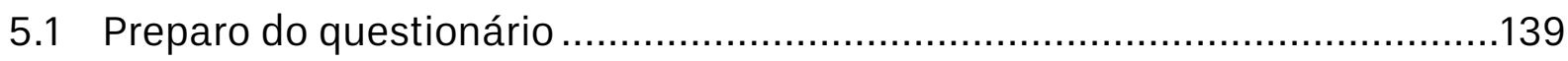

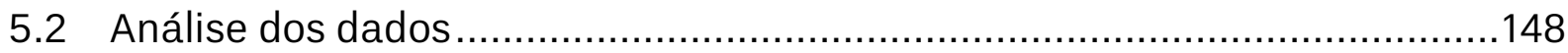

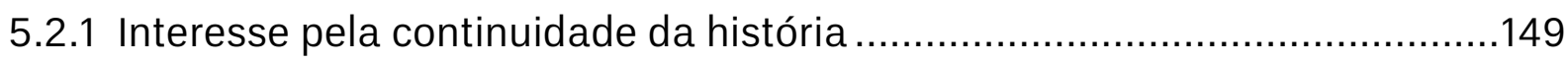

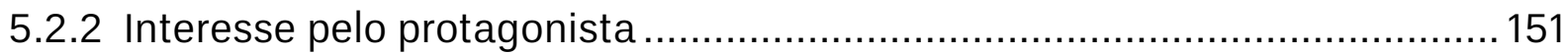

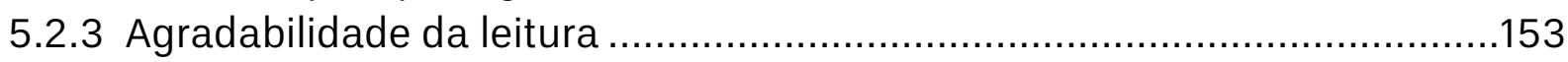

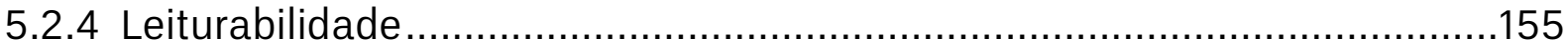

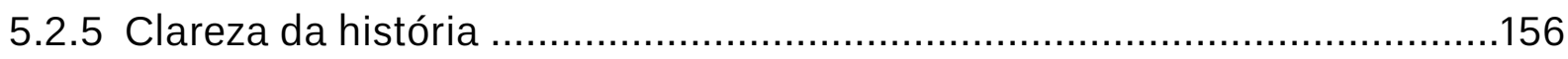

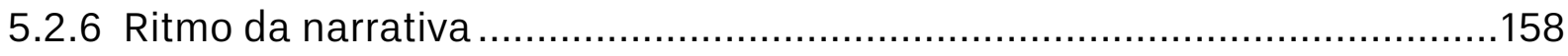

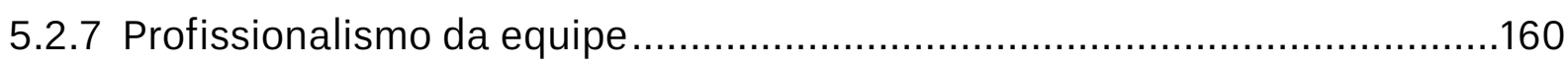

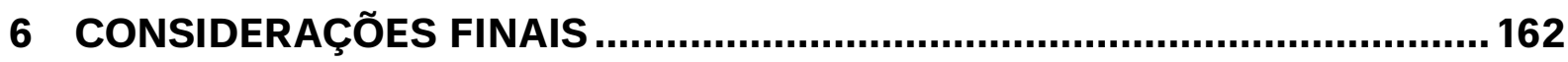

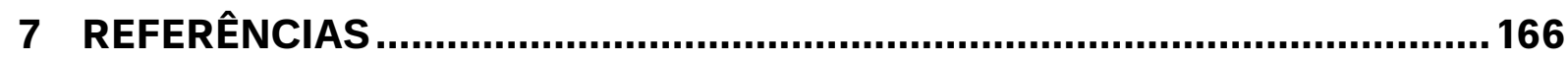

APÊNDICE A - Questionário respondido por Troy Peteri ............................ 176

APÊNDICE B - Questionário respondido por Todd Klein .............................. 179

APÊNDICE C - Questionário respondido por Lilian Mitsunaga ......................180

APÊNDICE D - Questionário respondido por Nate Piekos ..............................184

APÊNDICE E - Questionário respondido por Ron Marz ................................. 186

APÊNDICE F - Questionário respondido por Sidney Gusman ........................ 188 


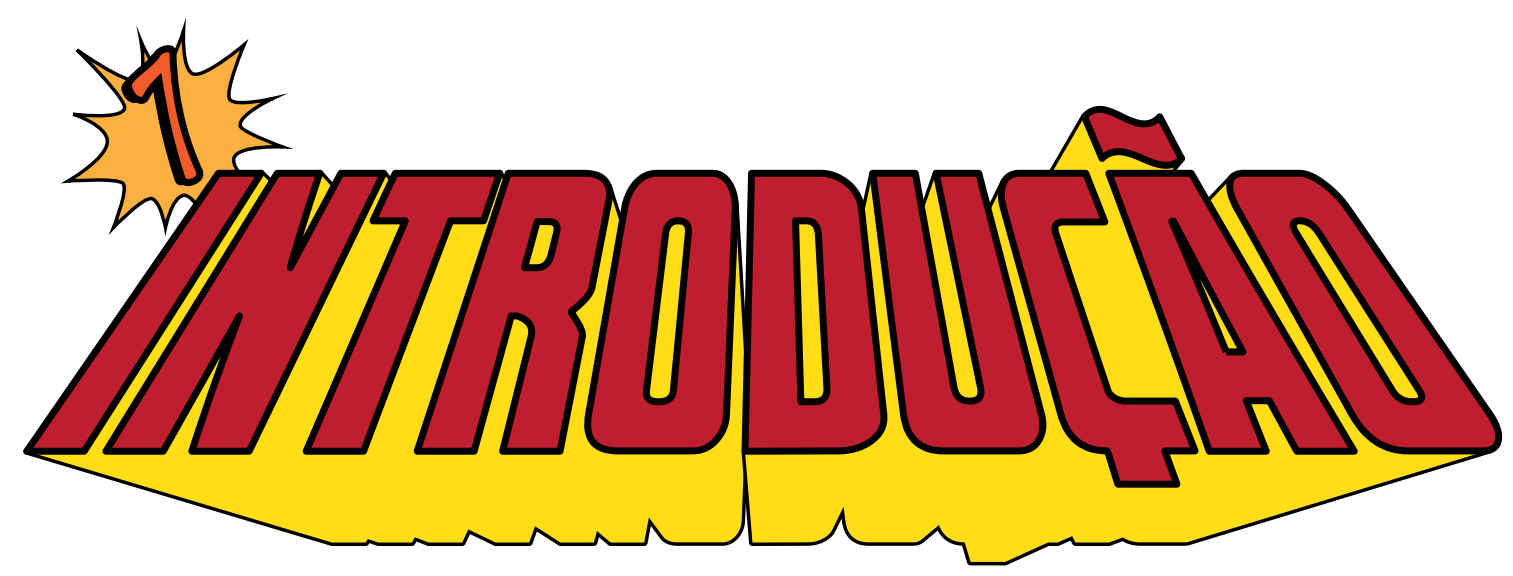

Após mais de um século entretendo o público, as histórias em quadrinhos deixaram de ser apenas uma atividade de lazer e passaram a ser consideradas como demonstração da arte e criatividade humanas. Trata-se de uma expressão gráfico-visual que tenta aprimorar a interação texto-imagem para contar histórias desde 1896, quando foi publicada a primeira tira de quadrinhos. Esta relação tornou-se mais harmoniosa com o surgimento do balão de diálogo por volta de 1900 juntamente aos primeiros ruídos onomatopaicos (Cirne, 1977, p.19), ambos considerados como particularidades marcantes da arte sequencial.

Com a popularização dos quadrinhos no decorrer dos anos 30 e 40, teve início a busca por especializações que agilizassem o lançamento das histórias. Por consequência, nasceram diferentes profissões para atender a essa nova procura, como é o caso dos letreiristas, que passaram a compor o processo de produção (Roshell; Starkings, 2003, p. 6). Responsável pela tarefa de desenhar os balões e acrescentar o conteúdo textual nas páginas, o ofício do letreiramento era inicialmente fixo em estúdios, mas a crescente demanda possibilitou o lançamento no mercado de profissionais autônomos (freelancers), que podiam trabalhar em casa, para artistas e títulos variados, sem necessidade de um segundo emprego.

Apesar de muitos cartunistas e desenhistas continuarem a traçar suas próprias letras em seus trabalhos, a chegada de especialistas em letreiramento ${ }^{1}$ acentuou a importância dessa etapa no resultado final. Percebeu-se que saber escolher o tipo de letra poderia tornar os títulos mais cativantes e que uma boa diagramação trazia mais clareza aos eventos retratados.

A exploração de todas as virtualidades gráficas fornece cada vez mais recursos que provocam diferentes sensações, intensificando a comunicação sonora nos meios visuais. Pode-se constatar isso com o posicionamento dos balões, o qual

1. A atividade de inserção dos textos nos quadrinhos é também encontrada sob os nomes "letreirização", "letreirismo" e "letrismo", sendo o terceiro o mais conhecido. No entanto, essa alcunha é também utilizada para a composição de letras de música e, por isso, optou-se por utilizar "letreiramento" em todo o projeto. De forma similar, o profissional é aqui chamado de "letreirista", pois o outro termo, "letrista", é adotado também pelos escritores de letras musicais. 
determina a cronologia do fluxo de ações, a duração do diálogo e da postura dos personagens falantes (Eisner, 2005, p. 63). Outro fator contribuinte é o estilo da tipografia empregada, que pode simular entonação, volume e emoção: as letras em maior tamanho e em negrito sugerem gritos, enquanto letras de tamanho menor expressam receio, timidez ou submissão. Assim, trabalha-se com uma extensa gama de estilos tipográficos para expressar as variações de tons e de ruídos, mostrando a função do letreiramento como a ferramenta de sonoplastia dos quadrinhos.

Sabe-se, então, que os enredos dos quadrinhos são transmitidos basicamente por meio das imagens, mas a disposição dos textos e o desenho das letras são recursos que, se bem utilizados, orientam a interpretação dos leitores para os fins do artista e/ou do escritor. No entanto, é dito por Starkings (2003, p. 11) que "o paradoxo de um bom lettering é que, quanto melhor ela for, menos o leitor nota-a" (nossa tradução). De acordo com ele, isso se explica porque quanto melhor for o trabalho feito, mais facilmente os leitores usufruirão da história e menos conseguirão perceber os detalhes que conduziram a essa facilidade. Ou seja, apesar de o setor de quadrinhos ter crescido vertiginosamente na última década, o letreiramento ainda é uma etapa oculta e pouco compreendida.

A proposta do presente projeto é apresentar um estudo aprofundado sobre o letreiramento, trazendo maior entendimento sobre o enriquecimento que as letras podem causar para a percepção da história e, assim, conduzir a uma maior visibilidade desse ofício.

\section{OBJETIVOS}

\section{Objetivo geral:}

Apresentar a importância do letreiramento para as histórias em quadrinhos.

\section{Objetivos específicos:}

a) Descrever o processo histórico do letreiramento, verificando o surgimento das tradições e a interferência de outros movimentos históricos;

b) Apresentar os aspectos trabalhados nessa etapa e assimilar os efeitos gerados na leitura e na percepção;

c) Apontar as principais diretrizes para o letreiramento eficiente e os erros comumente cometidos por iniciantes;

d) Discernir as incumbências e dificuldades do letreirista;

e) Encontrar elementos afetados nas histórias em quadrinhos pela qualidade do letreiramento. 


\section{CONTEXTO E PROBLEMÁTICA}

No campo dos quadrinhos, os Estados Unidos representam os líderes que promoveram essa mídia em 1934, e hoje são o país que mais exporta essa cultura. Nesse cenário, é natural que seja o local onde os letreiristas são mais valorizados. Os profissionais são regularmente convidados para entrevistas em convenções de quadrinhos ou para sites especializados. Ademais, o ramo é incentivado por compor uma categoria dos Prêmios Eisner, Prêmios Harvey Prêmios Eagle, principais premiações na indústria de quadrinhos norteamericanos. Ainda assim, os letreiristas alegam que seu trabalho continua invisível ao público (Starkings, 2003, p. 11).

Existem alguns guias publicados sobre formas de letreirar, como os de autoria de Roshell \& Starkings (2003) e Chiarello \& Klein (2004), porém, o conteúdo é principalmente técnico. As práticas convencionais são apresentadas sem que haja uma explicação de por que utilizá-las ou como surgiram, com exceção da tradição do uso de caixa alta. A atuação do profissional é esclarecida apenas no âmbito de seu trabalho individual, mas não são abordadas questões sobre mercado ou comunicação com a equipe.

No Japão, embora os autores prefiram que eles mesmos façam as letras de suas obras, muitos quadrinistas contratam assistentes para fazer o arranjo dos textos. As onomatopeias são bastante exploradas, a ponto de serem consideradas como um dos elementos de maior força expressiva nos mangás.

Assim como nos Estados Unidos, o estilo das letras é visto no Japão como um meio de acrescentar mais vivacidade à história, portanto, dicas de letreiramento são ensinadas nos cursos de quadrinhos. Infelizmente, este recurso ainda é tratado de maneira superficial, sob forma de pequenos tópicos, devido à bibliografia restrita sobre o assunto.

No Brasil, é possível ver o cuidado voltado para esse serviço em algumas editoras. O maior exemplo é o estúdio Maurício de Sousa Produções, o qual dispõe de especialistas em lettering para executar manualmente a parte escrita de seus gibis. No entanto, os estudos voltados para este tema e o ensino de lettering nos cursos de quadrinhos são precários, então boa parte dos letreiristas nacionais aprendem os vários efeitos provocados pelas letras através de experimentação por conta própria. 
Com o surgimento da profissão de letreirista e a inclusão dessa tarefa como categoria das maiores premiações da arte sequencial, a influência da letreiramento vem sendo evidenciada, mas o material de consulta permanece insuficiente. Publicações a respeito da criação de quadrinhos demonstram reconhecer a importância dessa etapa, contudo, transmitem apenas uma noção básica de como realizá-la.

Ainda faz-se necessário um estudo que esclareça como se consolidaram as convenções hoje conhecidas, assim como a funcionalidade de cada passo desse ofício, tal qual a balonização e a diagramação de textos, explicitando como esses recursos podem enriquecer o contar histórias. Essa carência de pesquisas faz com que o uso desses fatores não se dê de forma eficiente ou seja negligenciado na criação de quadrinhos.

A fatia do mercado referente à produção nacional está em expansão. Incentivos vêm de várias partes, desde divulgação de gibis nas escolas pelo governo até concursos para publicação pelas editoras. Nas instâncias políticas, circula também o Projeto de Lei 6060/09, que propõe a criação de uma reserva de mercado para as revistas em quadrinhos brasileiras. Porém, para enfrentar a competitivade no mercado estrangeiro, é necessário que o letreiramento seja aprimorado, pois, como se pretende mostrar neste projeto, é um processo que tem muito a acrescentar na fluidez com que se conta a história.

Propõe-se neste projeto contribuir a suprir a falta de referências sobre o assunto, apresentando conceitos relacionados e demonstrando diferentes formas de explorar os elementos da letreiramento.

\section{METODOLOGIA}

Para a execução deste projeto, foram utilizadas diferentes modalidades de método: bibliográfica, descritiva, experimental e exploratória, aplicadas em conjunto ou não, segundo a necessidade avaliada para cada seção. Embora a sequência de etapas pareça linear, o trabalho foi na verdade continuamente realimentado, complementando seu conteúdo a cada nova revisão ou descobertas posteriores.

A base teórica do projeto abrange uma pesquisa bibliográfica acerca do histórico dos quadrinhos com foco na evolução cronológica do uso do lettering. A trajetória foi montada a partir de textos sobre a história das HQs, com recortes específicos sobre eventos vinculados ao objeto de estudo. Procurou-se também fazer ligações com acontecimentos históricos marcantes, como guerras e movimentos artísticos. Todas as informações foram devidamente conferidas nas obras relacionadas antes de serem inseridas no trabalho. 
A atividade do letreiramento foi conceituada por pesquisa exploratória, dado que o tema não é muito conhecido. Devido à escassez de materiais impressos, recorreu-se principalmente a tutoriais online publicados por profissionais e análises de obras diversificadas. Com isso, foram levantados os fatores trabalhados nessa etapa (suportes de texto, tipografia, disposição do texto) e estes foram investigados em relação às suas principais características e as situações em que são utilizados.

Para traçar o perfil daqueles que se dedicam profissionalmente à área, foram feitos questionários abertos para profissionais da área visando a delinear o conceito de letreirista, suas incumbências e o referido mercado. Os questionários foram enviados por e-mail, compostos por 5 a 10 perguntas. Foi esclarecido que os respondentes poderiam responder apenas as questões que desejassem, mas nenhuma das perguntas foi deixada em branco.

Em seguida, alguns letreiristas foram contactados e todos aceitaram colaborar com o projeto, além de concederem permissão prévia para a publicação de suas respostas na dissertação. Estabelecendo perguntas claras e apropriadas, buscou-se definir a atividade de letreiramento, as etapas envolvidas, os desafios e o mercado de trabalho. Foram contactados também um escritor, Ron Marz, e um editor-chefe, Sidney Gusman, para preencher as lacunas referentes aos demandantes e compreender os critérios que buscam em um letreirista.

Os questionários aplicados foram constituídos de perguntas gerais a respeito da carreira e perguntas personalizadas para o entendimento de detalhes relacionados à atuação de cada profissional.

A partir das respostas e dos resultados obtidos ao examinar gibis variados, foram elaboradas diretrizes para um bom letreiramento. A qualidade do lettering foi usada como variável em um experimento social, onde foram procuradas as diferenças causadas na leitura dos quadrinhos pela forma como são letreirados.

O experimento foi composto por grupo controle e grupo experimental. A variável independente foi a qualidade do letreiramento. Já as variáveis dependentes trabalhadas foram a leiturabilidade, a clareza da história, o interesse do leitor em continuar lendo, o interesse pelo protagonista, o ritmo percebido da narrativa e a percepção do nível de profissionalismo da equipe.

Os participantes do grupo controle foram expostos a duas páginas de quadrinhos com alguns erros amadores de diagramação, porém mantendo a legibilidade do texto, enquanto o grupo experimental leu as mesmas páginas com o texto inserido e formatado segundo as diretrizes encontradas ao longo da pesquisa para um letreiramento eficiente.

Após a leitura, todos os participantes tiveram de responder às mesmas perguntas. O questionário foi feito em plataforma online, de maneira que cada participante respondeu individualmente com sigilo de identidade, sem conhecimento da divisão de grupos nem do real objeto de estudo.

As questões foram montadas em escala Likert, onde cada item consiste em uma afirmação e o partipante deveria marcar sua resposta entre cinco níveis de 
concordância ("discordo totalmente; discordo em parte; indiferente; concordo em parte; concordo totalmente").

Para atrair os participantes, foram criados marcadores de página magnéticos com um breve pedido de colaboração e com o endereço virtual para o questionário. A fim de delimitar a abordagem, os marcadores foram distribuídos apenas um pontos de concentração de fãs de quadrinhos, como eventos temáticos e prateleiras de gibis em bancas de revistas.

Após a coleta das respostas, foram aplicados testes de correlação para definir a interferência das variáveis dependentes entre si. Em seguida, as diferenças encontradas entre os dados foram mensuradas e comparadas conforme o tipo do questionário respondido. Mais testes foram realizados para verificar a intensidade de associação entre o letreiramento e as demais variáveis.

A existência de disparidade apresentada nas respostas entre os dois grupos já comprova que os elementos de lettering têm influência na leitura do produto final, portanto, trata-se de um objeto passível de mais estudos e mais experimentações para aperfeiçoar o contar histórias.

Espera-se que as conclusões neste projeto possibilitem maior compreensão da atividade e ampliem a notabilidade do ofício, que normalmente só obtém reconhecimento quando a legibilidade ou a leiturabilidade fica comprometida. 


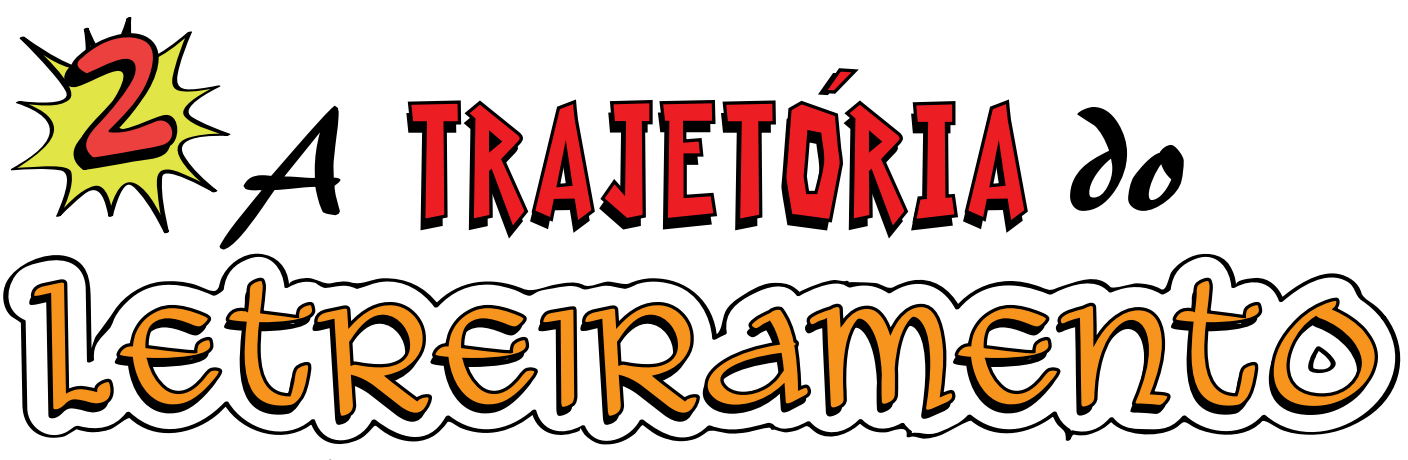

- HISTÓRIA DAS HQS FOCADA NO LETTERING •

conjunto de recursos utilizados pelas histórias em quadrinhos para integrar texto e imagem é amplamente difundido, de forma que o uso de balões já é um símbolo representativo da comunicação e as mudanças de tipos de letra são facilmente entendidas como variações tonais. Para chegar a esse patamar de reconhecimento, o letreiramento passou por um longo percurso de experimentações, aprimoramentos e rejeições. Esse trajeto foi composto por colaborações e obstáculos de diferentes países e de variados eventos históricos. Este capítulo apresenta a história da arte dos quadrinhos com foco na evolução dos elementos do letreiramento, desde o século XIV até a contemporaneidade.

A busca pela interação entre texto e imagem resultou na criação de novas formas para narrar histórias, como as charges e os livros ilustrados. Essa exploração de recursos gráficos deu origem às histórias em quadrinhos, cuja inserção das palavras escritas se dá principalmente por meio dos balões, chamados assim por seu caráter flutuante e formato normalmente arredondado. Dada a popularidade dessa mídia, os balões de fala ficaram conhecidos como elementos pertencentes às histórias em quadrinhos, mas seu surgimento se deu em outros suportes, décadas antes de aparecer a primeira tira em sua forma convencional.

Para entender como foi concebida a ideia ao balão, devemos voltar à Era Clássica, onde estão os mais antigos registros do rabicho ou apontador - a parte do balão que indica o emissor da mensagem. A Figura 1 mostra uma das cenas pintadas no vaso de cerâmica K1398, peça de arte mesoamericana que possui explicações textuais e citações diretas dos personagens. 
Figura 1. Vaso K1398, também chamado de "Rabbit pot"

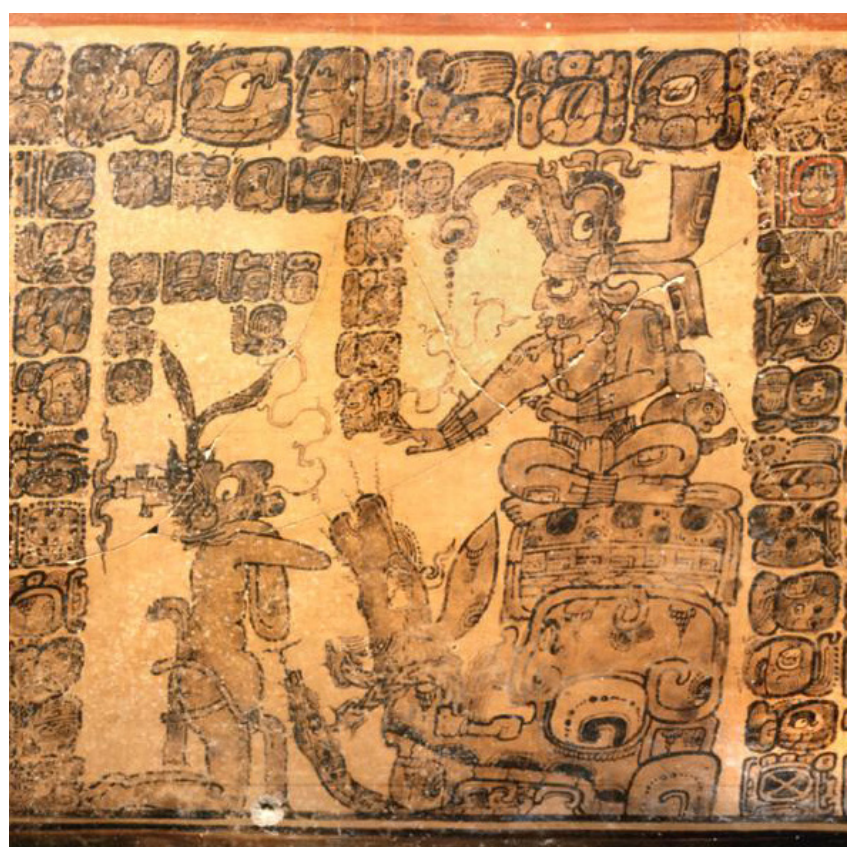

Fonte: http://research.mayavase.com/kerrmaya_hires.php?vase=1398 (2014); @Justin Kerr

A figura representa a conversação entre um vassalo e o Deus L. O texto narrativo encontra-se margeando o desenho, enquanto o diálogo é empregado em caracteres menores. É possível ver uma linha fina e ondulosa ligando o último caractere de cada fala à boca do respectivo locutor, indicando a quem os dizeres são atribuídos. Segundo Hull (2003, p. 216), dezenas de documentos e monumentos do Vale do México produzidos no mesmo período apresentam essa mesma linha de ligação, podendo indicar canção em vez de fala.

No século XIII, constata-se outra experimentação de juntar o texto à imagem: o pergaminho, também chamado de filactério. A fala era escrita em uma faixa que pairava oscilante no ar, de forma a intervir o mínimo possível na arte, e desenrolava-se até a boca do falante (Figura 2) ou o pergaminho era segurado por ele (Figura 3). Apesar de o encaixe bamboleante do texto comprometer sua legibilidade, essa solução foi estabelecida como um padrão na arte ocidental que durou até o século XVIII. (Marsden, 2013) 
Figura 2. Bois Protat, a xilografia mais antiga remanescente do Ocidente, criada entre 1370 e 1380

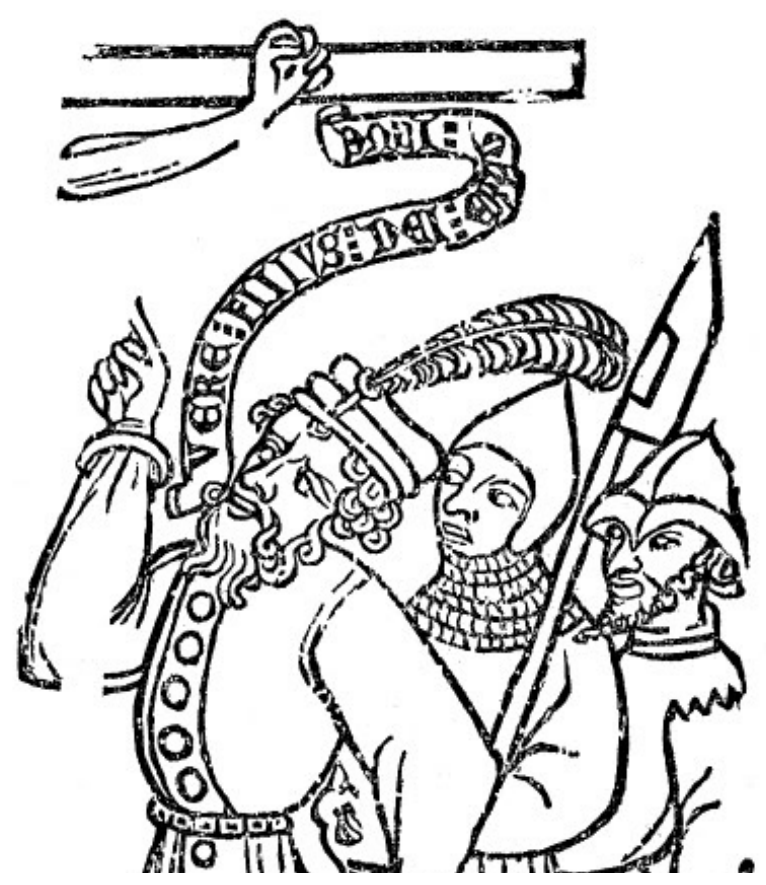

Fonte: http://sainttail.com/miloindex.htm (2014)

Figura 3. Osterspiel, de cerca de 1500, retrata uma peça de teatro medieval com o personagem segurando sua fala

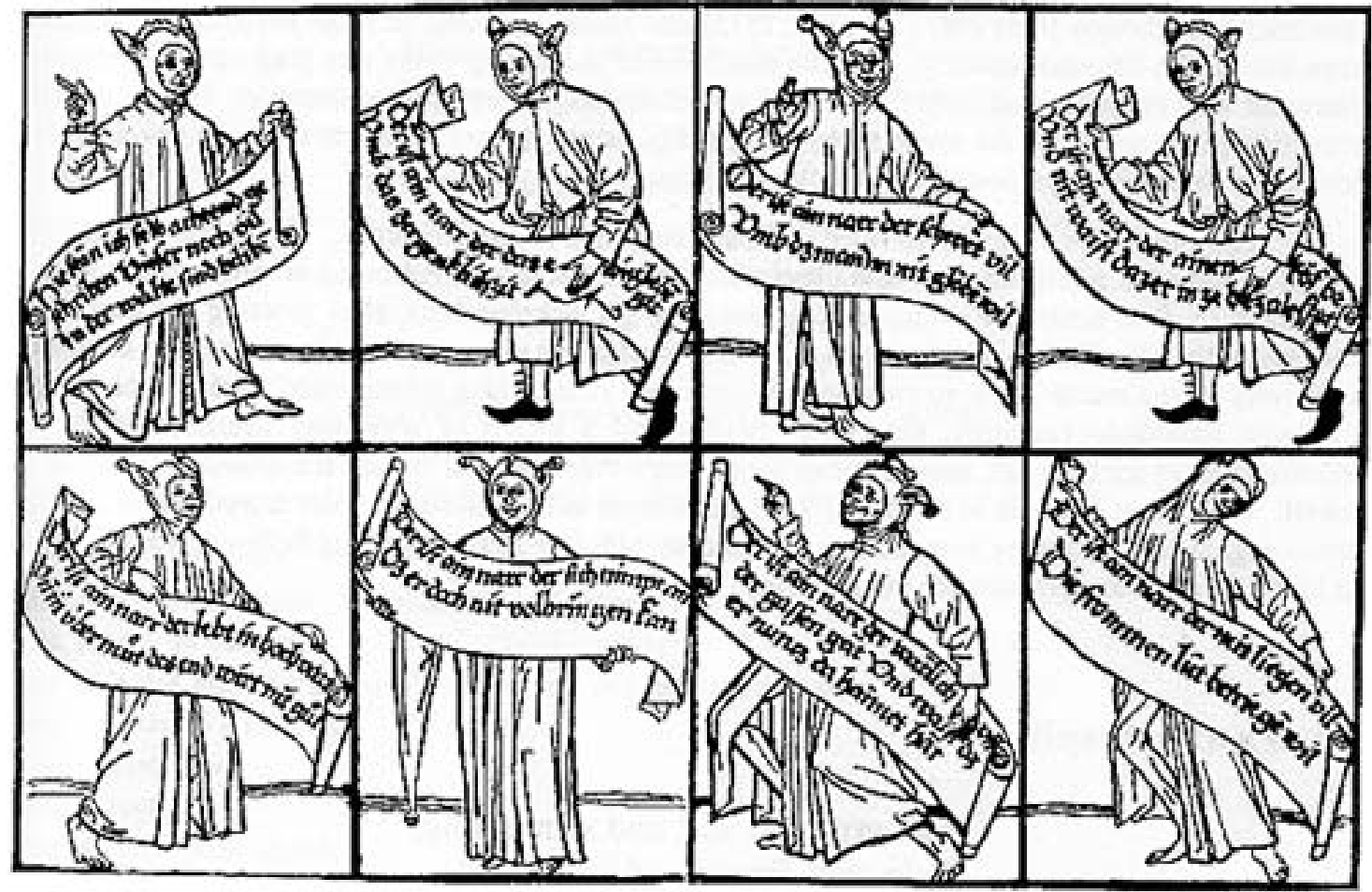

Fonte: http://bugpowder.com/andy/ (2013) 
Já no Oriente, os filactérios foram dispensados. Como mostra a obra Fukutomi Soushi (Figura 4), do século XIV, a representação da fala no Japão tinha um desenrolar mais livre, onde o texto era escrito em posição próxima aos personagens emissores.

Figura 4. Fukutomi Soushi, do século XIV

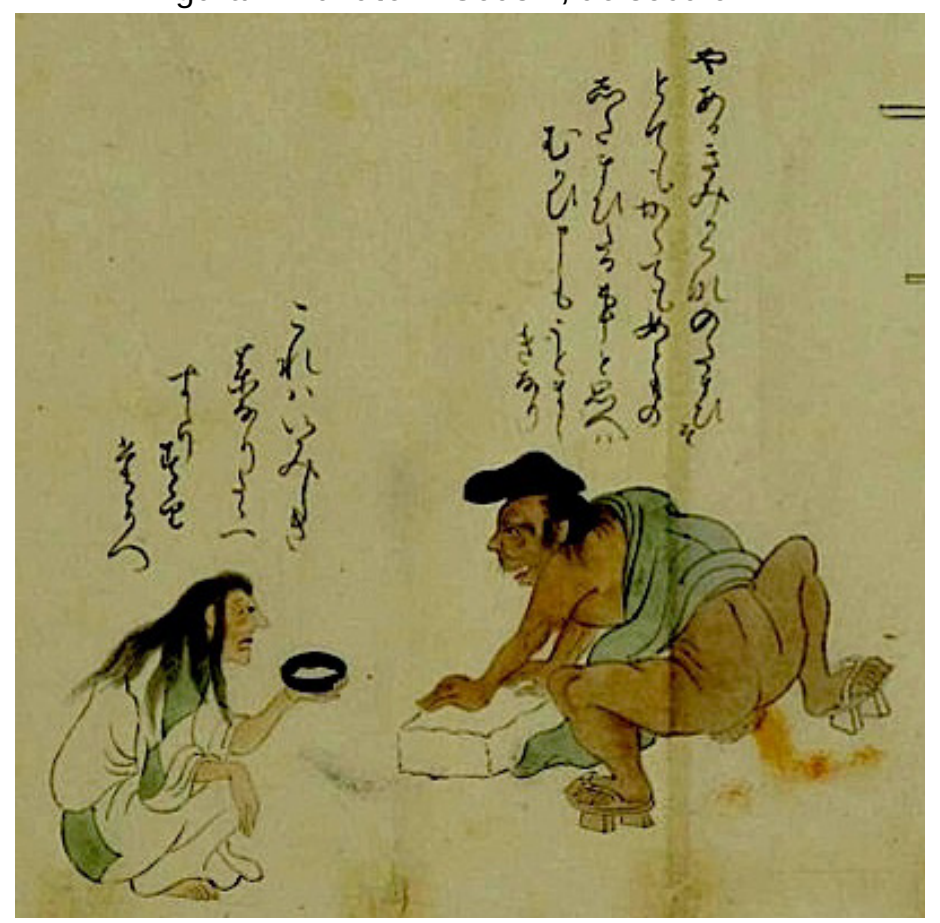

Fonte: http://logusoku.com (2014)

A invenção da imprensa no Ocidente dificultou a inserção do texto sobre as imagens, já que ambos requeriam diferentes métodos para serem reproduzidos. Os textos voltaram a aparecer apenas abaixo das ilustrações e a coexistência das duas linguagens se enrareceram. (McCloud, 2005, pp. 143-144)

Os tipos móveis apareceram no Japão por volta de 1600, mas como o sistema de escrita japonesa requeria muitas peças tipográficas, os métodos manuais ainda eram mais eficientes, portanto, a imprensa não teve influência significativa na forma como o diálogo era disposto. O estilo do Ukiyo-e ${ }^{2}$ começou a florescer e as falas continuavam a ser representadas sem suporte específico, apenas escritas perto de seu emissor.

Os pergaminhos tiveram novo destaque em 1682, na Inglaterra, quando Francis Barlow fez uso consistente deles em seu folheto The Horrid Hellish Popish Plot (Figura 5). Seus trabalhos exibiam uma forma simplificada de filactério, tornando-o mais parecido com os balões de fala.

2 Técnica de pintura executada com o auxílio de blocos de madeira, desenvolvida no Japão durante o período Edo. 
Figura 5. A true narrative of the horrid hellish Popish Plot, de Francis Barlow, 1682

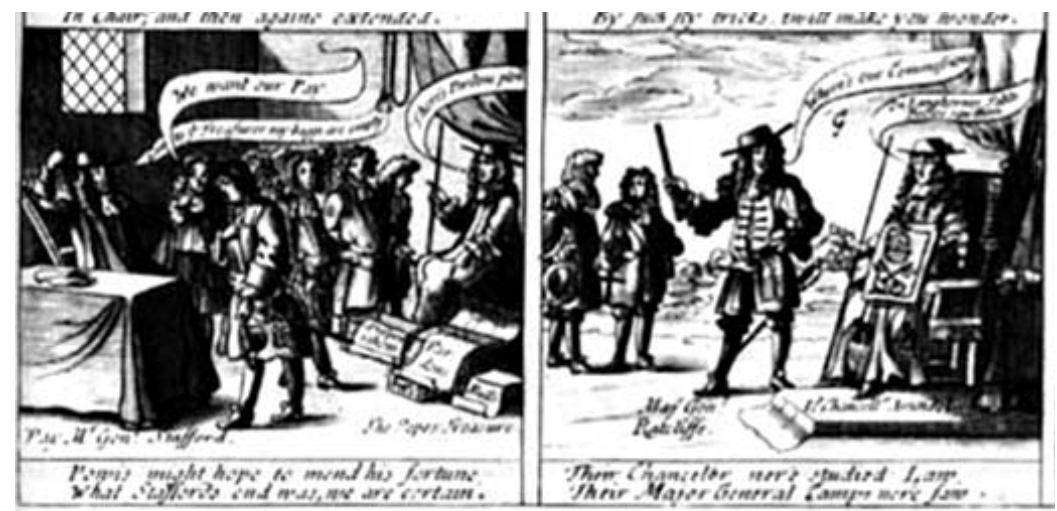

Fonte: http://bugpowder.com/andy/ (2013)

Embora trabalhos semelhantes ao de Barlow, tais como A Rake's Progress, de William Hogarth (1726), estabeleçam uma narrativa através de uma sequência de imagens, os elementos utilizados por eles só iriam se cristalizar em uma história em quadrinhos no século XIX. (Gravett, 2005) Mesmo assim, os pergaminhos sofreram uma evolução quanto à função desempenhada: se antes eles serviam apenas para citações diretas, agora eles ajudavam a contar a história.

O uso de bandeirolas e filactérios decaiu mais uma vez em prol do método dos livros ilustrados, alternando blocos de texto e painéis, pois era mais fácil identificar quem era o personagem falante. (Figura 6) (Bradley, 2014) Além disso, os artistas começaram a perceber que os pergaminhos volantes não incorporavam valores realistas e passaram a abandoná-los. (Marsden, 2013)

Figura 6. Lenard und Blandine, obra de Joseph von Goez escrita em 1783

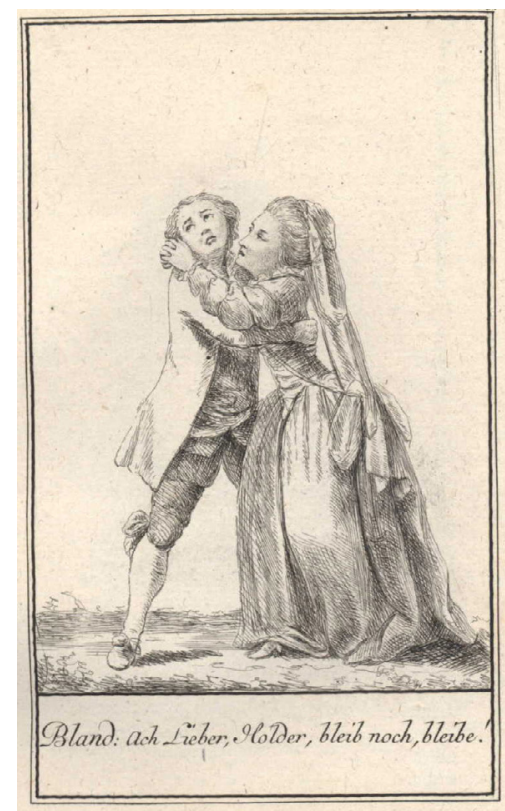

Fonte: http://bugpowder.com/andy/ (2013) 
Os antecedentes do balão não haviam sido bem aceitos para narrativas, mas ainda eram frequentes em charges políticas britânicas. Algumas dessas chegavam a usar duas ou mais imagens interdependentes para narrar a situação, como mostra a Figura 7. Konkycru (2011) aponta esse fato como um progresso, pois as bandeirolas utilizadas desenvolveram-se como um meio de atribuição de diálogo.

Figura 7. The table's turned, James Gillray, 1756-1815

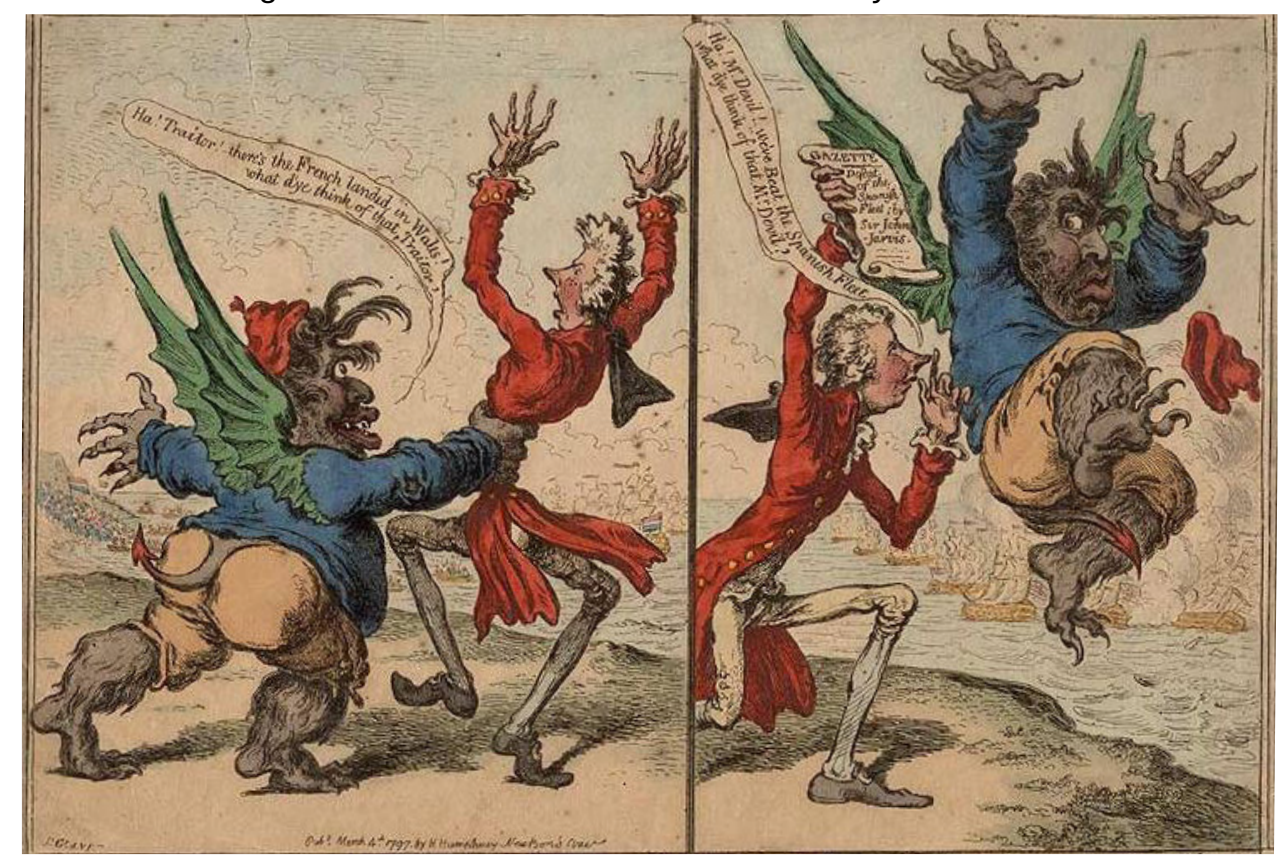

Fonte: http://bugpowder.com/andy/ (2013)

Os caricaturistas do século XVIII também usavam comumente esse recurso e mestres da caricatura, como James Gillway e George Cruikshank, adotaram formas gráficas mais circulares para atribuir falas a Napoleão e a outros políticos proeminentes da época. (Marsden, 2013) As bandeirolas e os filactérios estavam finalmente cedendo lugar aos balões rechonchudos, (Konkycru, 2003) entretanto, eles se mantiveram exclusivos aos cartuns políticos por muitas décadas.

No mesmo século, as pinturas em estilo Toba-e ganhavam popularidade no Japão. Apesar de ser considerado precursor do mangá moderno por ter uma sucessão de imagens que progrediam em tempo e espaço, o Toba-e exibia pouco ou nenhum texto. (Van Lente; Dunlavey, 2012, p. 188)

A novidade que surgiu nesse tempo que favoreceu o lettering foi o advento dos kinbyōshi, livros de capa amarela que continham longas histórias contadas principalmente através de imagens, mas a presença de textos integrados era usual. (Danziger-Russell, 2013, p. 132) A obra Kinkin-sensei eiga no yume, publicada em 1775 e de autoria de Koikawa Harumachi, é considerada uma das primeiras da categoria. Em uma das ilustrações presentes na história, (Figura 8) é possível ver uma das primeiras aparições de um modelo similar a um balão no Oriente, onde linhas circundam uma narração e levam-na à cabeça do homem, simulando um sonho. 
Figura 8. Kinkin-sensei eiga no yume, por Koikawa Harumachi, 1775

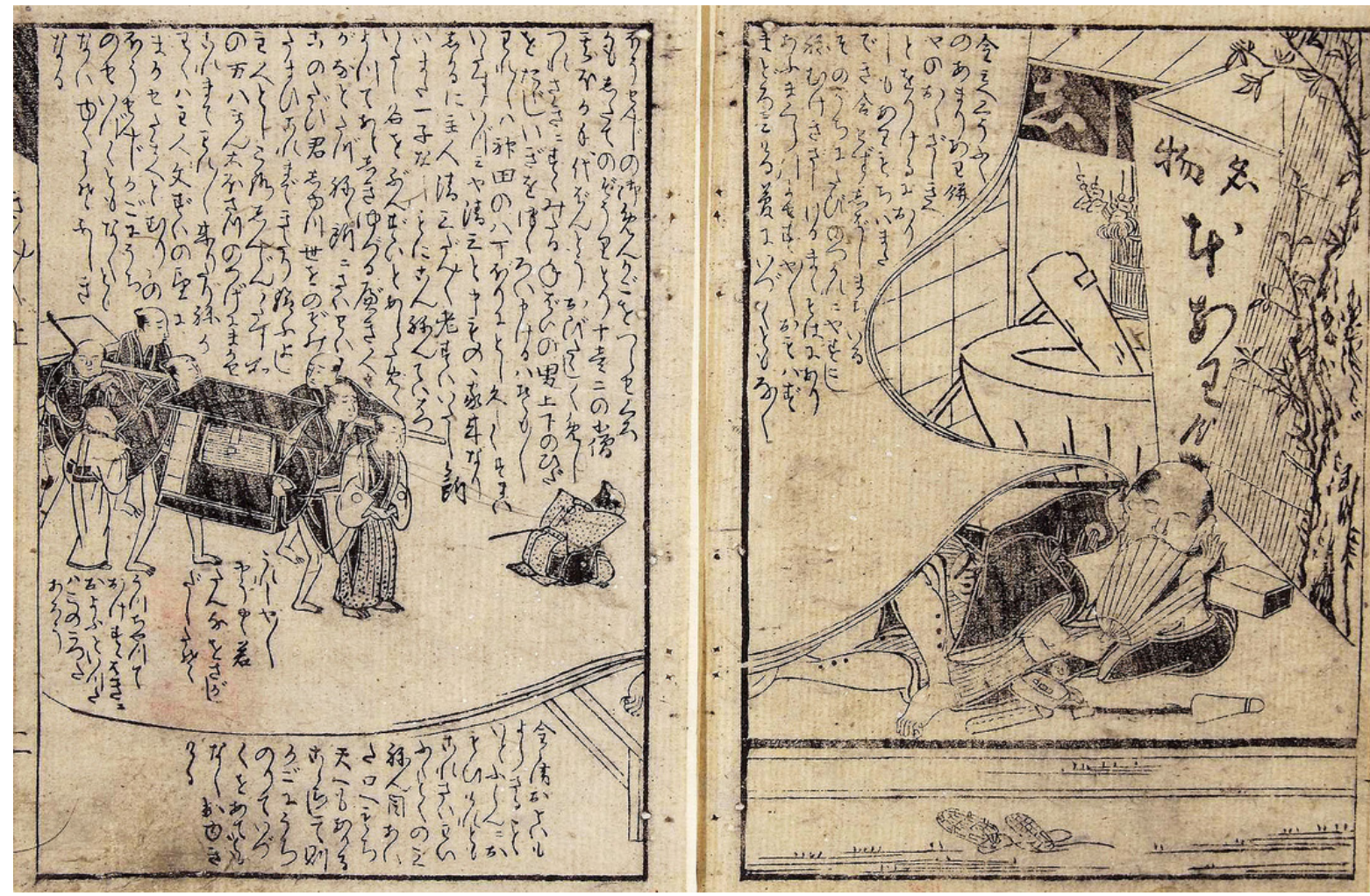

Fonte: http://alvinmurphy1.weebly.com/history-of-manga.html (2014)

Danziger-Russell $(2013$, p.132) destaca que o uso dos balões inicialmente copiava a ideia chinesa de representar sonhos, lembranças, visões e fantasias com formas que remetiam a nuvens, as quais serviam para emoldurar cenas à parte do cenário principal. Com exceção da inauguração dos balões, a evolução da diagramação gráfica textual acompanhada de imagens se manteve estagnada no continente asiático. Em 1814, o termo "mangá" foi criado por Katsushika Hokusai, (Van Lente; Dunlavey, 2012, p.187) mas os 15 livros que ele publicou sob essa alcunha não possuíam narrativa escrita nem diálogo.

Também no Ocidente, palavra e imagem encontravam-se distanciadas no âmbito da literatura, sendo combinadas esporadicamente nos impressos europeus. Foi Rodolphe Töpffer quem tornou a aproximá-las no início do século XIX (McCloud, 2005, p. 149) ao relatar histórias usando ilustrações sequenciais, com um pedaço da narração compartimentalizado abaixo de cada uma. (Figura 9) Seus trabalhos foram impressos nos Estados Unidos e por toda a Europa, incentivando a reaproximação das duas linguagens. 
Figura 9. Monsieur Trictrac, por Rodolphe Töpffer, 1831

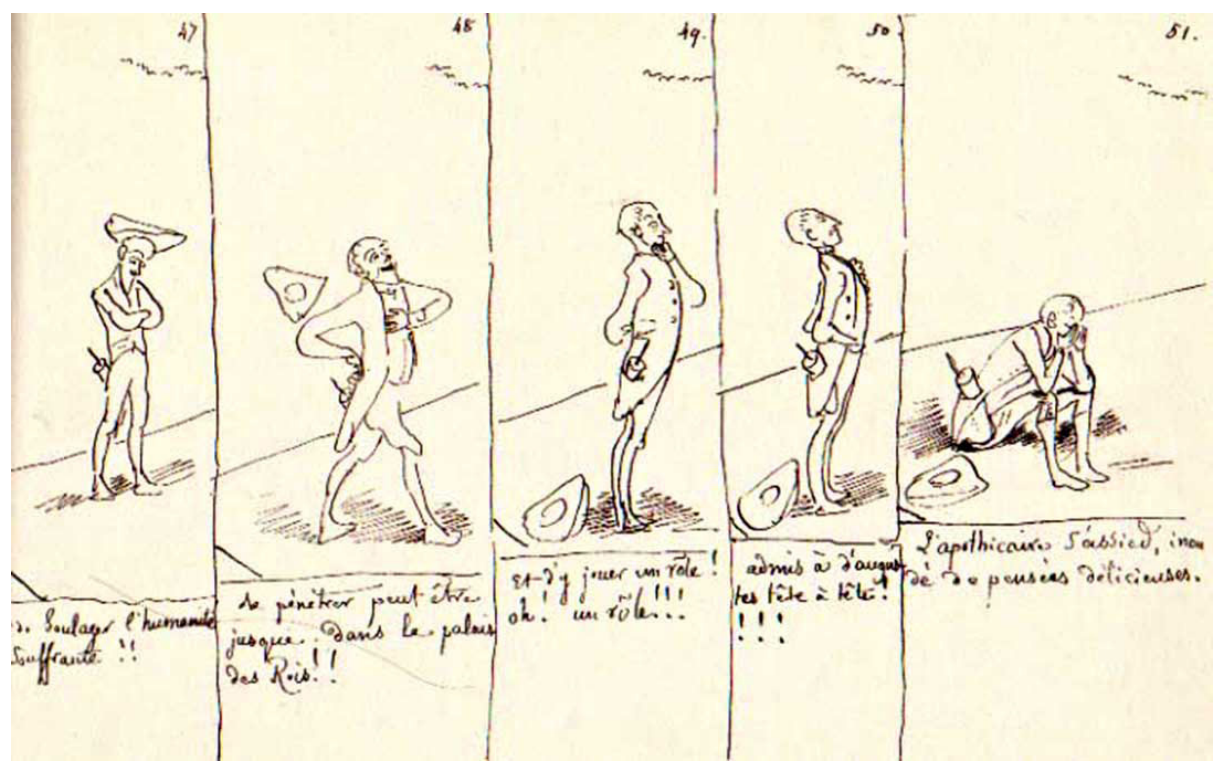

Fonte: http://bugpowder.com/andy/earlycomics1827.html (2013)

Alguns chargistas persistiam no uso dos balões, como é o caso de George Cruikshank. Este é o responsável por um dos exemplares mais antigos que exploram o encadeamento gráfico de falas. (Figura 10) A alternância de perguntas e respostas revela a eficácia do recurso para controlar ritmo, cronologia e sequência visuais.

Figura 10. A good penny-worth, por George Cruikshank, 1820

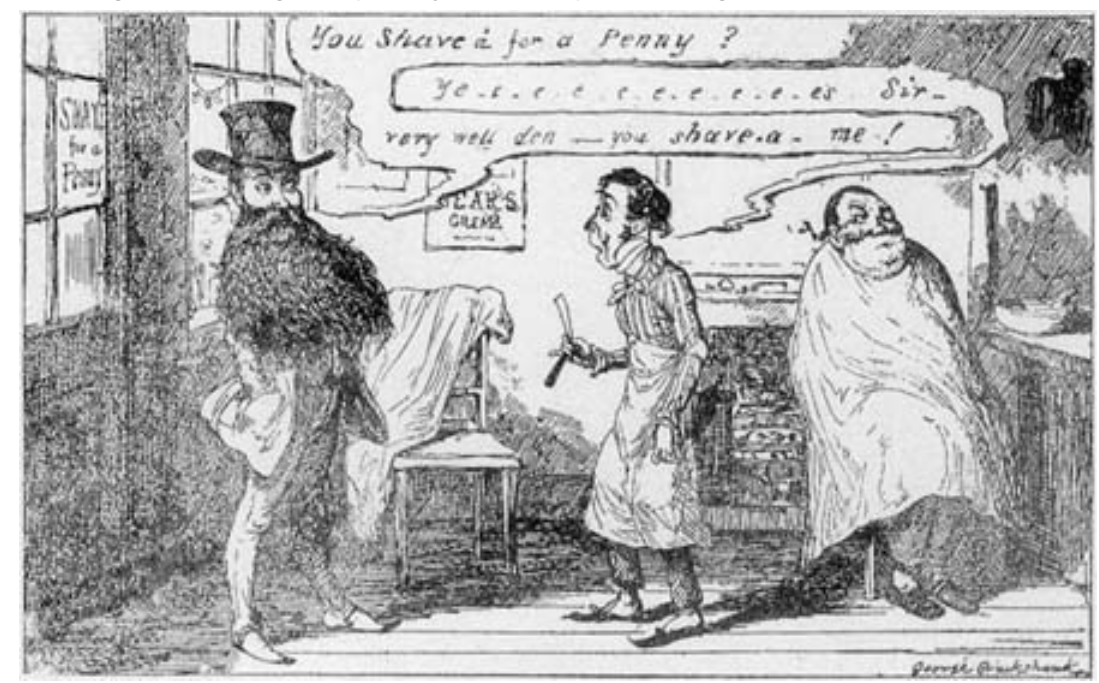

Fonte: http://bugpowder.com/andy/ (2013)

No Reino Unido, um grande passo foi dado em 1826, quando William Heath desenhou a primeira edição de The Glasgow Looking Glass (posteriormente conhecido como The Northern Looking Glass). Heath retomou o uso dos balões de fala no cânone literário (Figura 11) e, para isso, ele buscou resolver a questão da irrealidade do balão tornando-o mais difuso no cenário, parecendo mais uma fumaça do 
que uma base sólida. Ademais, por possuir muitos dos elementos que caracterizam os quadrinhos modernos, como a caricatura, as legendas contando a narrativa em partes e até o uso do "Continua", muitos estudiosos sugerem que foi essa obra que guiou o caminho das histórias em quadrinhos de humor. (Stewart-Robertson, 2013)

Figura 11. Quadro de McLean's monthly sheet of caricatures No. 14 - or The Original Looking Glass, por William Heath, 1831

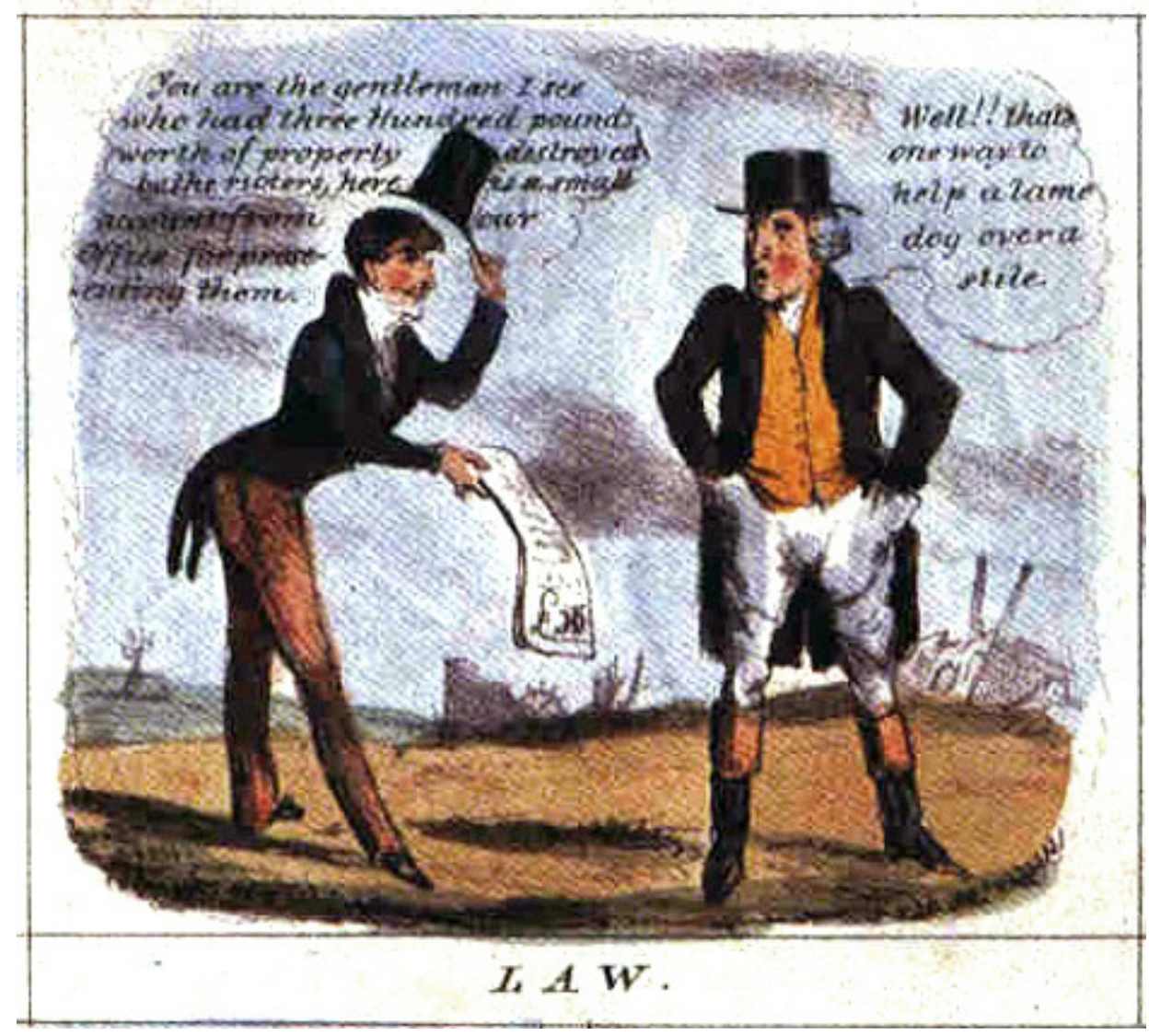

Fonte: http://britishgoldenagecomics.blogspot.com.br/2014/06/defining-british-ages-of-comics-again.html (2014)

O inglês Charles Wingman expandiu o alcance do balão ao levá-lo até Yokohama, em 1862, através de sua publicação The Japan Punch, a qual era recheada de sátiras ao estilo britânico. Assim, mais uma mudança foi acrescentada à lista de transformações por que o Japão estava passando na modernização da era Meiji. (Luyten, 2001-2002, p. 178)(Danziger-Russell, 2013, p. 133) 
Figura 12. The Japan Punch $n^{\circ}$ 6, por Charles Wirgman, 1865

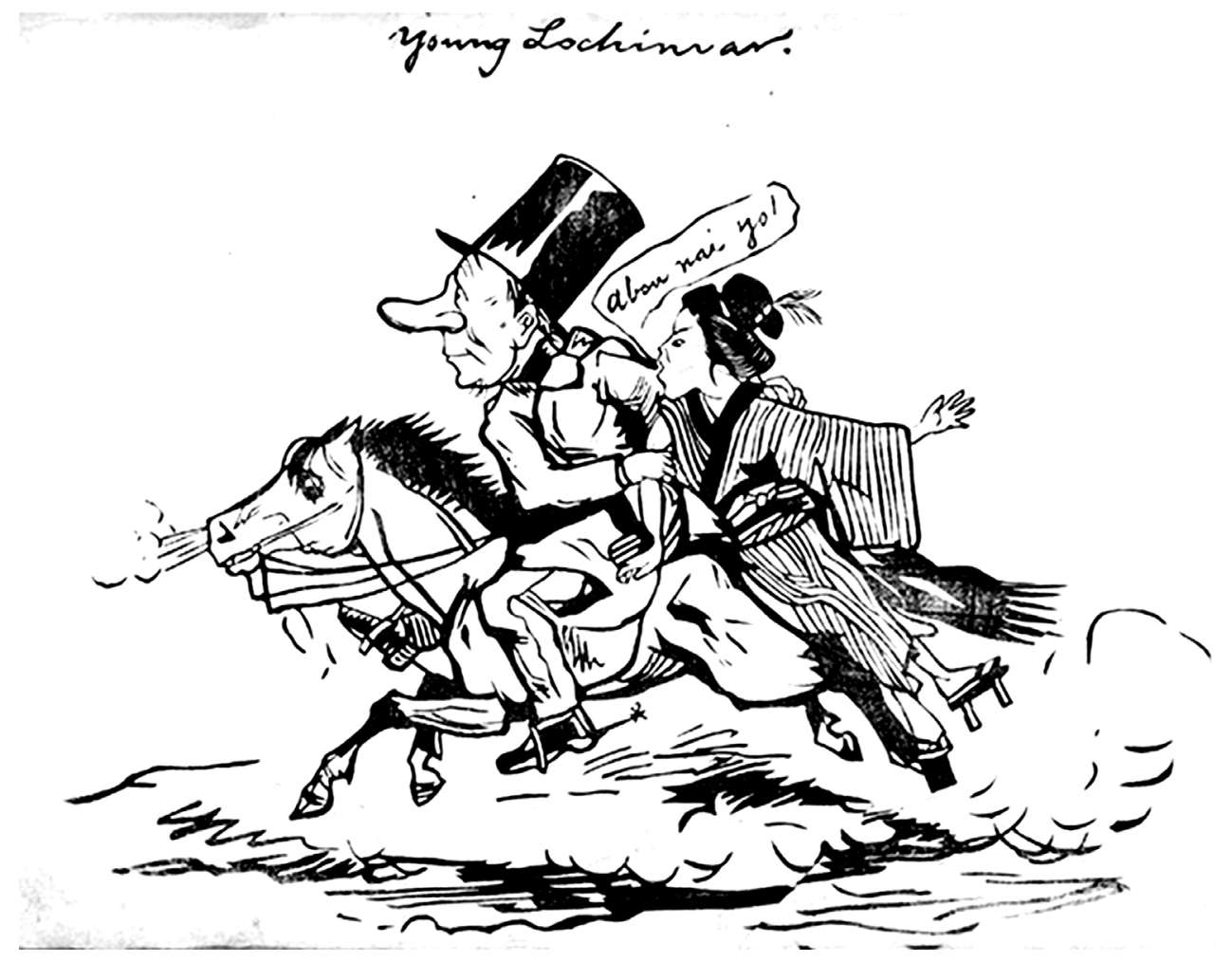

Fonte: http://www.peterharrington.co.uk/rare-books/asia/the-japan-punch-1865-6/ (2014)

O Japão logo começou a absorção desse novo molde. Kobayashi Kiyoshita foi um dos primeiros a incorporar a técnica, com o uso de balões nos cartuns políticos que publicou em Maru Maru Chinbun, em 1886, (Luyten, 2012, p. 130). Graças ao preço baixo da revista, o estilo rapidamente alcançou as massas.

No Ocidente, por volta de 1870, os trabalhos que utilizavam sequência de paineis aderiam ao formato familiar da época: exibiam o bloco de narração abaixo de cada cena e raras vezes utilizavam o balão. No Brasil, a receita foi a mesma para a primeira história em quadrinhos de que se tem notícia, As aventuras de Nhô Quim, produzida pelo italiano Angelo Agostini. (Figura 13) Segundo Patati e Braga (2006, p. 20), "o talento único de Agostini o tornou precursor não só das HQs como da charge política e do cartum brasileiros". 
Figura 13. As aventuras de Nhô Quim, por Angelo Agostini, 1869

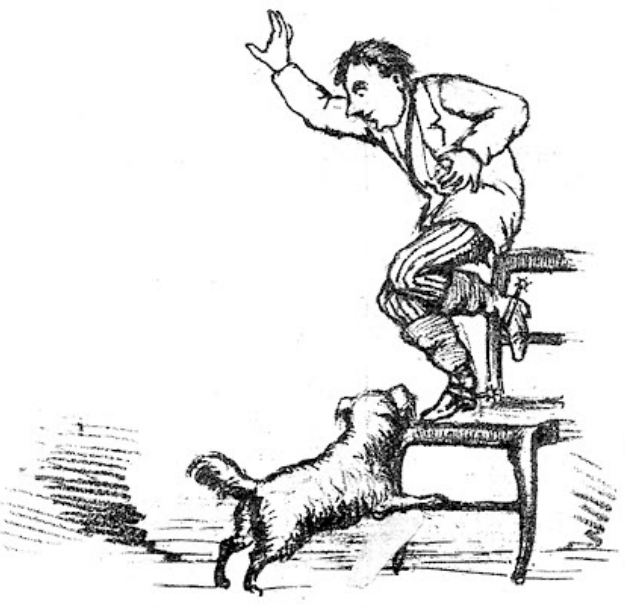

Procurou um refúgio, mas vendo que nem assim se livrava da sanha do diabo do totó,
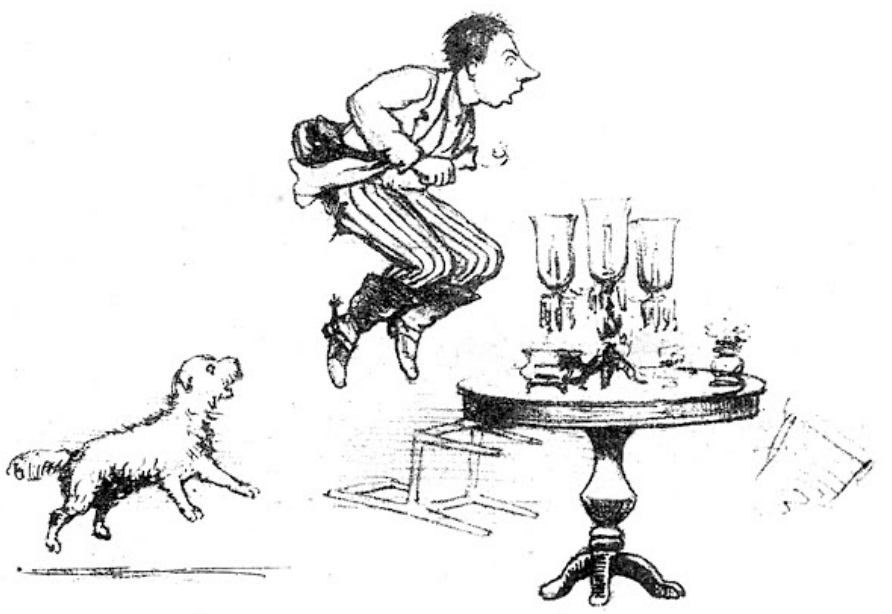

pulou sobre a mesa, pondo tudo em estilhaços.

Fonte: http://historiahoje.com/?p=3091 (2014)

\section{TIRAS CÔMICAS}

Até então, as ações compreendidas por meio de um conjunto de imagens, os diálogos inseridos na ilustração e o uso dos balões não eram nenhuma novidade. No entanto, faltavam ainda alguns ingredientes para que todos esses precursores fossem considerados histórias em quadrinhos. Eis que, em 1896, Richard Outcault preenche essa lacuna com a concepção de The Yellow Kid nos Estados Unidos. Apesar de não possuir bordas delimitando os quadros, as aventuras do garoto trajando um camisolão amarelo são geralmente creditadas como as primeiras tiras de quadrinhos. (Walker, 2004; Marsden, 2013; Patati; Braga, 2006, p.16)

Inicialmente, as falas do protagonista, Mickey Dugan, apareciam estampadas em sua veste, como mostra a primeira cena da Figura 14. Os balões foram acrescentados pouco tempo após a estreia e a popularidade da série tornou-a uma força motriz para que o formato da tira fosse copiado por outros artistas. 
Figura 14. The Yellow Kid and his new phonograph, por Richard Outcault, 1896

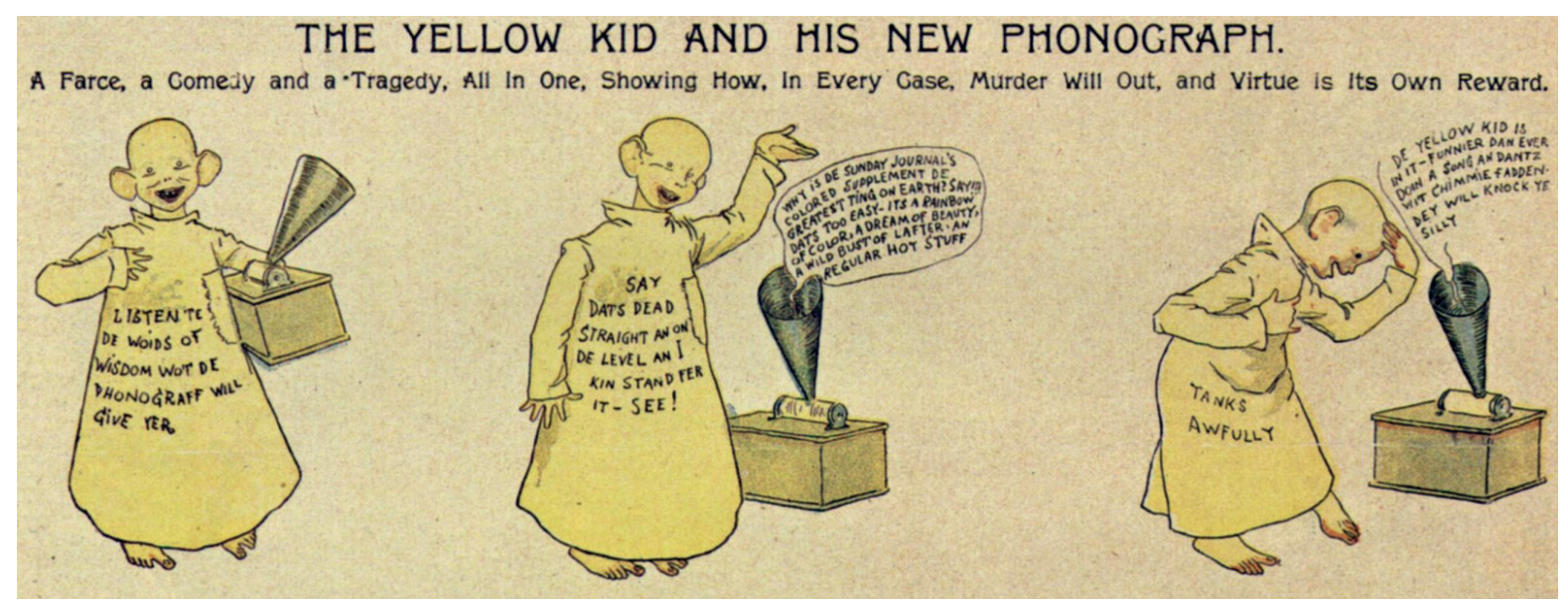

Fonte: http://superitch.com/?p=16317 (2014)

Se essa receita já havia sido usada anteriormente, por que The Yellow Kid recebe o prestígio de ser a primeira história em quadrinhos? O ponto a ser explorado aqui é a necessidade da conversação na trama. Nos proto-quadrinhos, as falas serviam apenas como acessórios aos acontecimentos ilustrados, enquanto na obra de Outcault, elas se tornaram fundamentais para a transmissão da piada. Era a primeira vez, nos trabalhos gráficos, que a ideia principal da história dependia do diálogo. (Blackbeard; Williams apud Van Lente; Dunlavey, 2012, p. 8)

Antes disso, a própria ideia de conjunto de paineis divergia do conceito de arte sequencial. Normalmente, eram apenas compiladas várias ilustrações com mesmo tema, sem conexão necessária entre si. Outcault foi pioneiro em injetar tempo às imagens, tornando vivas as trocas entre os personagens:

\footnotetext{
"Mas enquanto os 'proto-quadrinhos' podem ter tido sucessivas imagens e/ou diálogo, a inovação de Outcault foi fundir os dois juntos em uma cadência narrativa que resultava em um fac-símile da vida real, como ela era vivida por seu leitor."
}

(VAN LENTE; DUNLAVEY, 2012, p. 8)

Em 1900, o americano Frederick Burr Opper passou a usar o balão como base regular em suas histórias (Happy Hooligan e Alphonse and Gaston) para o Sunny Pages. (Figura 15) Os balões eram disformes, acompanhando a silhueta da mancha textual de cada fala, e os rabichos finos serpenteavam até estarem bem perto do personagem emitente. Assim como em The Yellow Kid, os balões de Opper mostraram-se mais do que um acompanhamento supérfluo para as ações visuais, pois transformavam suas histórias em uma síntese de arte e texto, em que os dois eram igualmente importantes para a compreensão dos acontecimentos. (Maschall apud Lefèvre, 2006) Seus colegas norte-americanos, como Swinnerton e Dirks, logo adotaram a técnica (Blackbeard apud Lefèvre, 2006). 
Figura 15. Happy Hooligan, por Frederick Opper, 1920

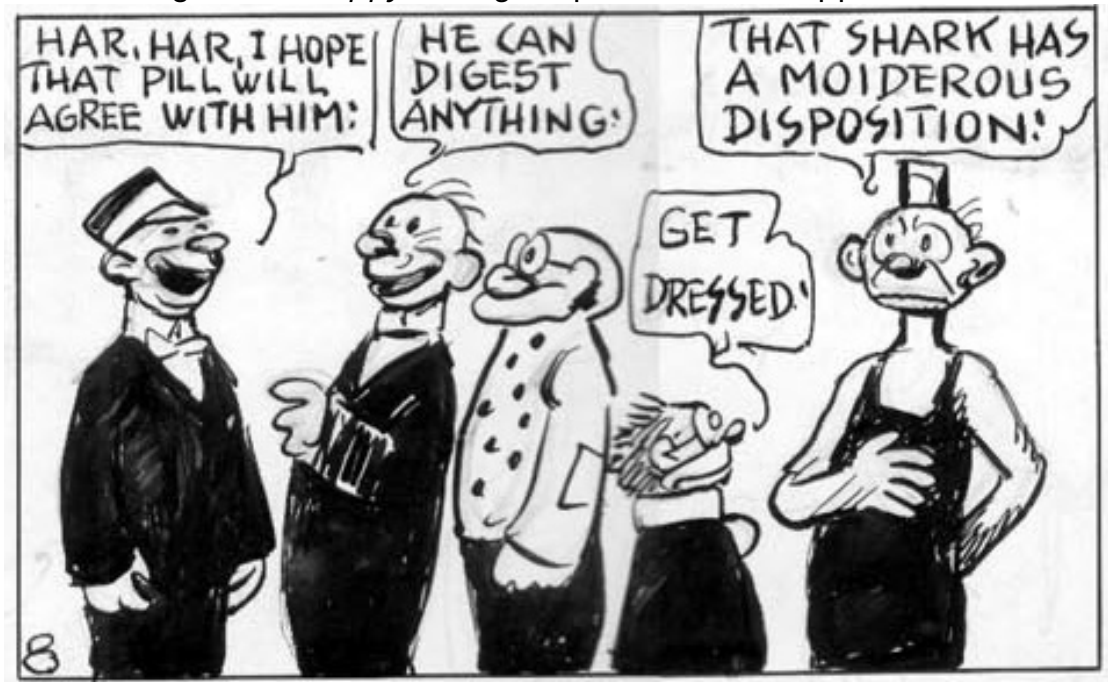

Fonte: http://www.comicartfans.com/ (2014)

Dentro de alguns anos, o balão deixou de ter apenas aparições tímidas, conquistou as páginas de quadrinhos norte-americanos e adicionar texto diretamente sobre as imagens se tornou uma prática comum. (Bradley, 2014) Isso não significa que as legendas tenham sido inutilizadas. Elas ainda estavam bastante presentes, principalmente para narrações. Walt McDougal uniu as duas formas, usando os baIões para o texto oral, e, como ainda não existiam as nuvens de pensamento, as legendas apareciam entre aspas e representavam o monólogo interno do personagem principal. (Figura 16) Esse método distingue-se de uma narrativa em primeira pessoa por ser mais espontâneo e menos descritivo.

Figura 16. Professor Jyblitz, Walt McDougal, 1902

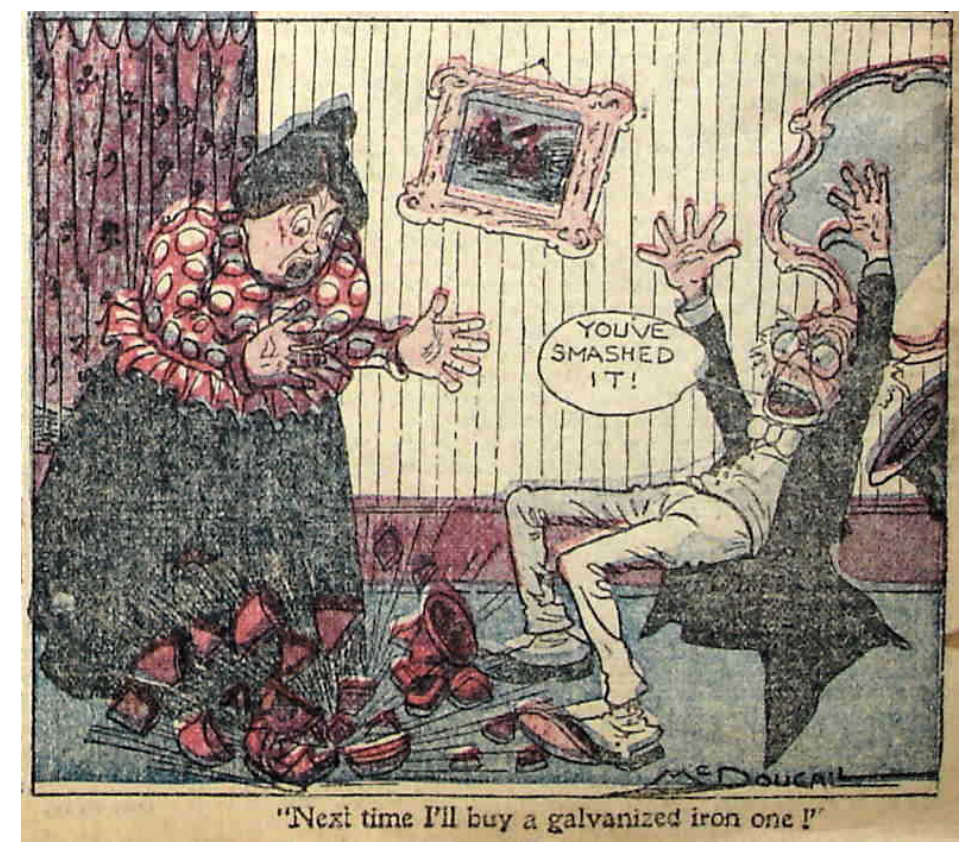

Fonte: http://konkycru.com/ (2013) 
No Brasil, constatam-se usos diferentes da legenda em O Tico-Tico, primeira revista brasileira de quadrinhos. Nesse caso, pode ser que a falta de contato com obras balonizadas tenha acarretado esse desdobramento. Na primeira edição da revista, lançada em 1905, a história Manda quem pode (Figura 17) mostrava a conversação segundo os roteiros audiovisuais: o locutor é enunciado em letras maiúsculas, precedendo a fala correspondente.

Figura 17. Manda quem pode, por J. R. Lobão, 1905

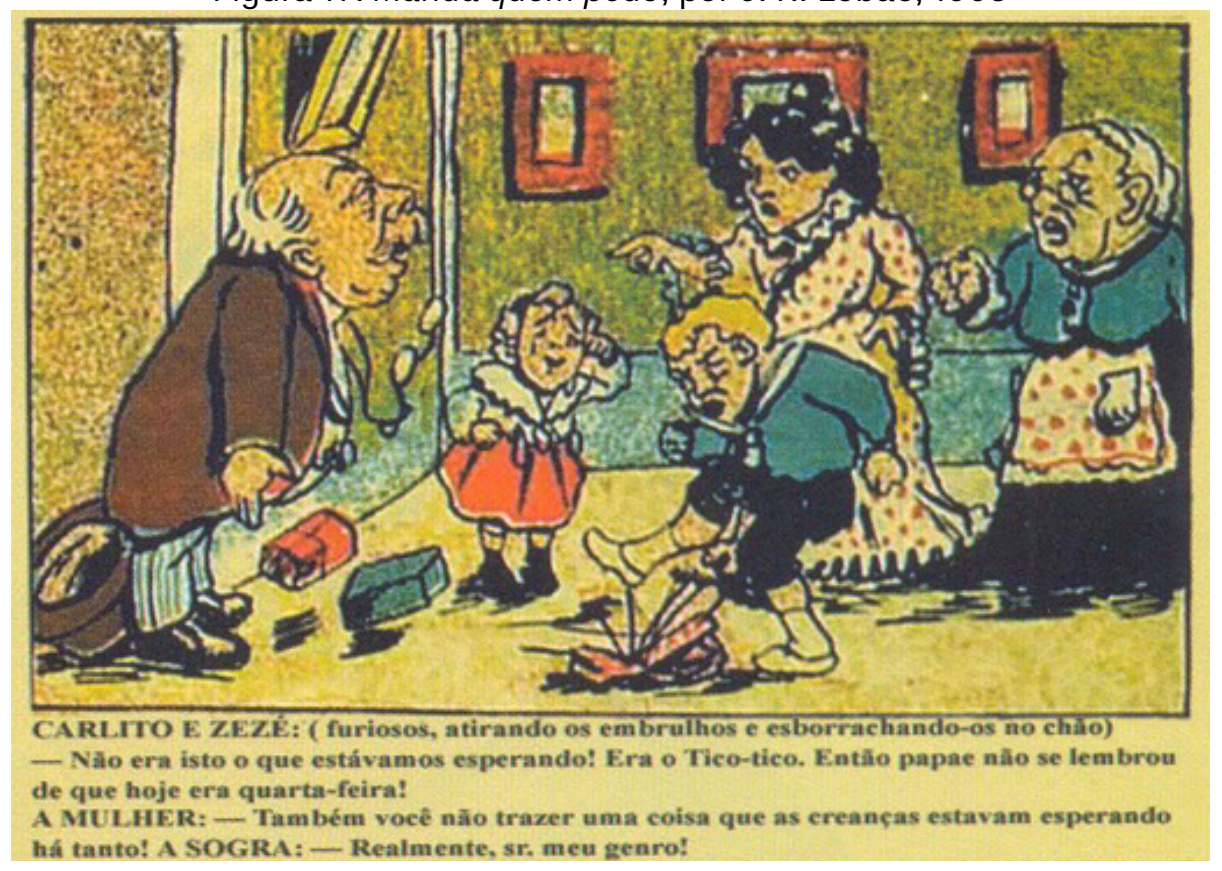

Fonte: http://www.guiadosquadrinhos.com/edicao/tico-tico-o-n-1/ti173100/24467 (2013)

No campo dos quadrinhos, a disposição horizontal dos painéis se provava como a orientação mais fluida para a leitura e o uso de bordas nos quadros tornava cada imagem em uma unidade inconfundível. (Van Lente; Dunlavey, 2012, p. 12) As duas características já começavam a virar regra.

Bud Fisher adotou os mesmos moldes para Mr A. Mutt (que logo se tornou Mutt and Jeff), estreado em 1907. A essa altura, os sinais de pontuação já vinham se padronizando mundialmente, acompanhando a ascensão da imprensa. Fisher tirou proveito dessa propagação e inseriu pontos de interrogação isolados para demonstrar dúvida ou confusão. Seu trabalho foi um dos primeiros a testar diferentes tamanhos e espessuras de letra para evocar diferentes tons de voz. Na Figura 18, Jeff fala com as letras mais grossas que as de Mutt, para simular uma tonalidade grave. No entanto, como essa prática não era comum, Fisher precisou explicar por escrito como o texto deveria ser entendido. 
Figura 18. Mutt and Jeff, por Bud Fisher, 1929

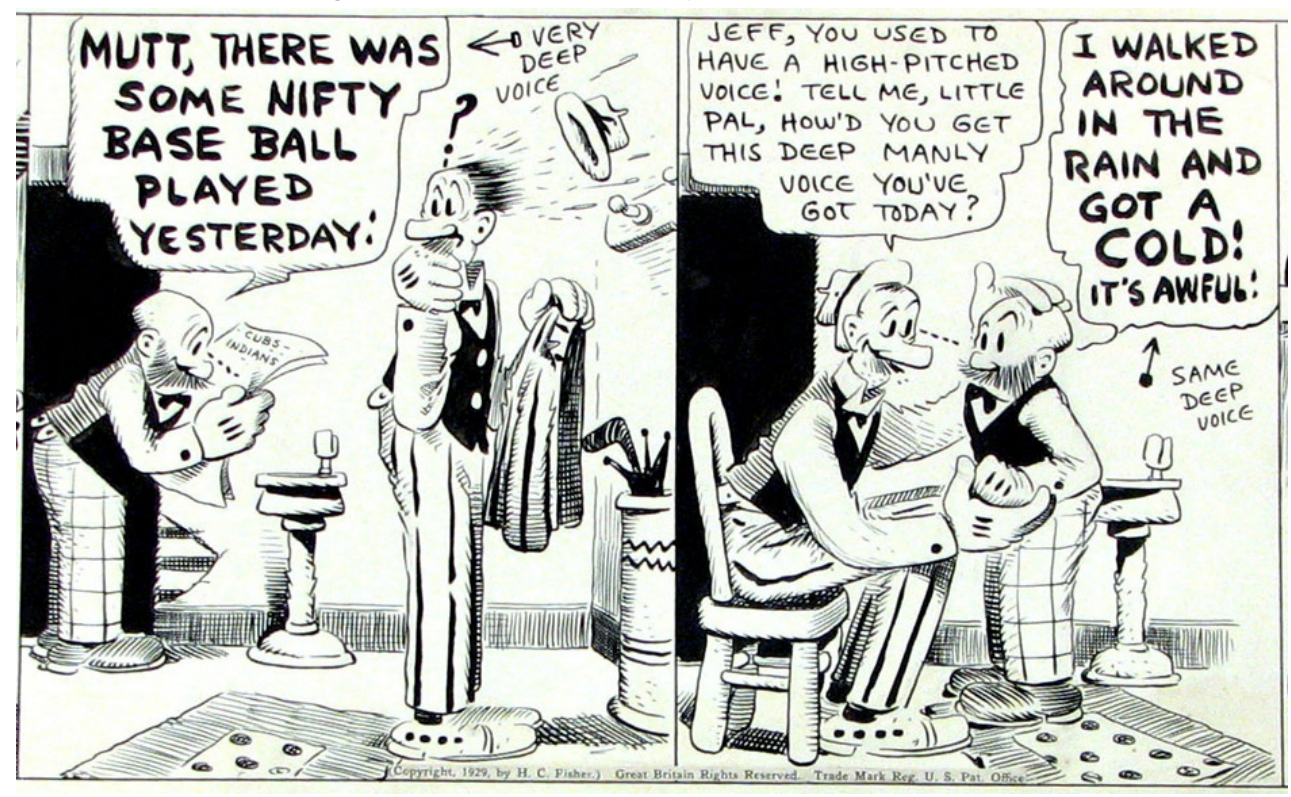

Fonte: http://comicartfans.com (2013)

Enquanto isso, a obra-prima de Winsor McCay aumentava sua fama a cada edição de domingo do jornal The New York Herald. Little Nemo in Slumberland trouxe consigo uma série de inovações, desde variação dos tamanhos dos quadros para enfatizar determinadas ações até as vistas por diferentes perspectivas, em oposição aos cenários estáticos com quadros uniformes predominantes nas histórias em quadrinhos do momento. (Van Lente \& Dunlavey, 2012; 13)

Com início em 1905, as primeiras tiras de Little Nemo seguiam o paradigma de usar balões de fala juntamente às legendas, que vinham blocadas abaixo de cada imagem, seguidas do número do respectivo quadro. Levaram-se 20 publicações para que McCay decidisse eliminar os textos narrativos, que se tornavam redundantes por explicarem o que a imagem transmitia de forma autônoma. Todavia, a enumeração dos quadros foi mantida, mesmo que a orientação de leitura tenha se tornado óbvia.

A notoriedade de sua história foi de grande contribuição para popularizar o modelo de quadrinhos com balões e sem legendas. Ademais, o autor foi um dos pioneiros a mudar os tamanhos de letra em um mesmo balão para indicar as mudanças de volume vocal. Também foi um dos primeiros a perceber que a ausência da imagem do locutor não interfere na compreensão dos acontecimentos: frequentemente aparecem falas sem que o proferidor esteja na cena, com o rabicho do balão apontando para uma borda do quadro. (Figura 19) 
Figura 19. Little Nemo in Slumberland, por Winsor McCay, 1907

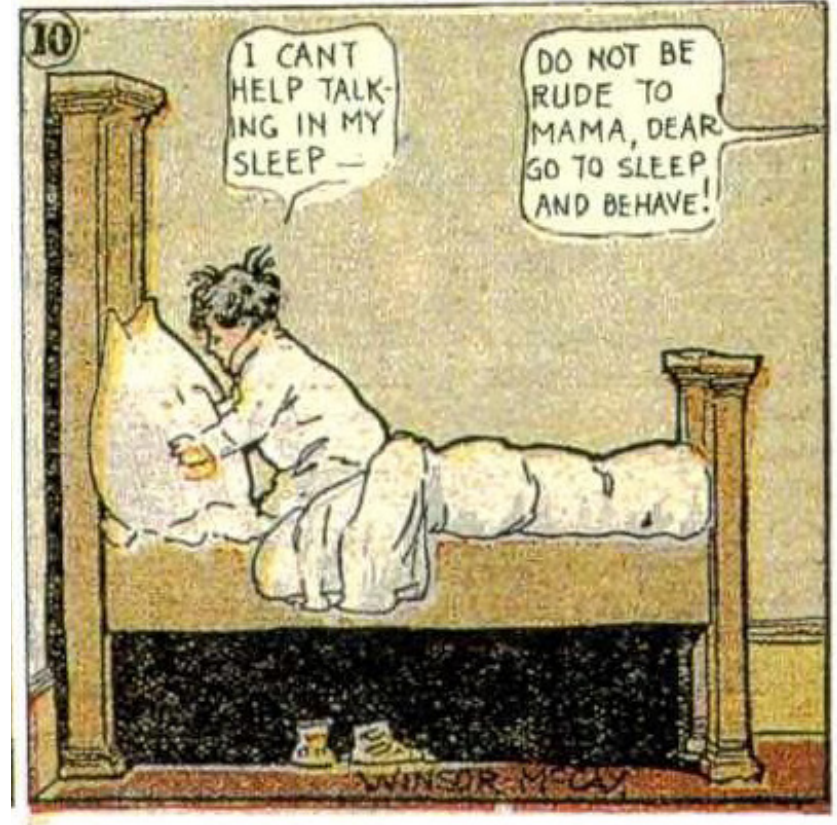

Fonte: https://archive.org/details/LittleNemo1905-1914ByWinsorMccay (2014)

Graças a sua dinamicidade, a ideia do suporte redondo para os textos foi um sucesso quase imediato nos Estados Unidos e se propagou mundo afora através da reimpressão das tiras americanas em outros países.

O Japão estava passando por uma fase de absorção intensa da cultura ocidental e nisso incluíram-se as histórias em quadrinhos, que beneficiavam as vendas de impressos. Alguns títulos, como Bringing up father e Mutt and Jeff, estavam sendo traduzidos para os jornais locais e seu formato foi logo seguido por cartunistas e chargistas japoneses. A cópia limitou-se apenas à estrutura da tira e o conteúdo era adaptado ao gosto nipônico. (Luyten, 2012, p. 90-91)

A tira francesa Les pieds Nickelés, de Louis Forton, nasceu em 1908 e incorporou a técnica, (Patati; Braga, 2006, p. 23) mas a Europa em geral não se convenceu a adotar o modelo americano e continuou a usar blocos de texto por décadas. Apenas tiras cômicas inglesas aderiram a esse recurso, já que a Grã-Bretanha tinha mais acesso aos quadrinhos americanos por compartilhar o mesmo idioma. Mesmo assim, os balões não substituíam os textos narrativos; eles complementavam-nos. (Lèfevre, 2006) Enquanto no Estados Unidos as histórias em quadrinhos eram promovidas como uma atividade familiar, os europeus viam essa mídia como uma fase de transição das crianças no trajeto para a verdadeira literatura. Como os textos em prosa eram considerados mais educativos, os balões caíram em desvalor. (Giromini, 1996, p. 99)

Os países latino-americanos se mostraram mais receptivos aos balões. (Aurrecoechea \& Bartra apud Lefèvre, 2006) A Argentina, cujo maior avanço rumo às histórias em quadrinhos antes de 1900 foram as tirinhas sobre a vida real (cuentos vivos), também foi conquistada pela fórmula americana e esta foi aplicada em Las 
aventuras de Viruta y Chicharrón, de Manuel Redondo, em 1912. Apesar de ser uma recriação de Spareribs and Gravy, do norteamericano Geo Mac Manus, a obra é considerada a primeira história em quadrinhos argentina, por ser contínua e apresentar personagens fixos. (Szymanczyk, 2014, p. 84)

No México, foram as complicações em conseguir as licenças e traduzir as histórias estrangeiras que impulsionaram os jornais a patrocinar produções locais. Assim, o jornal El Heraldo comissionou o artista Salvador Pruñeda para criar Don Catarino, sob o paradigma americano. Seguindo o exemplo, várias tiras mexicanas começaram a circular no país. (Duncan; Smith, 2009)

Cabe ressaltar aqui que, com a propagação do estilo estadunidense das histórias em quadrinhos, o arsenal de onomatopeias em inglês também acabou se difundindo. Segundo Zanettin (2009, p. 39), a remoção e a substituição de texto eram uma tarefa trabalhosa que consistia em raspar o conteúdo das imagens originais e substituí-lo à mão. Quanto mais trabalho, mais cara ficava a história em quadrinhos; a alteração gráfica dos efeitos sonoros foi tomada como muito custosa e, portanto, eles eram mantidos da forma como haviam sido concebidos.

Em todos os lugares, o cartunista era o responsável por todas as etapas de produção, incluindo a inserção de texto, que era feita com a caligrafia regular do artista, com algum esmero para melhorar a legibilidade. Portanto, era a habilidade em arte que ditava o interesse em trabalhar pelo ramo. Para evitar dividir os lucros e como não havia exigência rigorosa quanto à escrita, era inviável contratar assistentes para letreirar. (Bradley, 2014)

Nas figuras colocadas até aqui, é possível perceber que as letras eram colocadas livremente, sem espaçamentos padronizados e, às vezes, nem sequer seguiam linhas retas. A invenção da régua chamada Ames Guide, em 1917, tornou o letreiramento em uma tarefa mais fácil e com aparência mais alinhada. Essa ferramenta garante a consistência no tamanho e a uniformidade das letras.

Também conclui-se a partir das imagens vistas que a maioria dos artistas preferia usar letras maiúsculas. Isso se justifica porque as tiras tinham sua resolução reduzida para serem publicadas em jornais e revistas, e as letras maiúsculas mantinham-se mais legíveis que as minúsculas. Segundo Bradley (2014), o Ames Guide reforçou essa preferência porque, com o uso desse instrumento, eram necessárias linhas extras para marcar a altura-x das letras minúsculas e quaisquer descendentes, (Figura 20) fazendo com que o uso de caixa alta fosse mais conveniente.

Figura 20. Altura-x e linha das descendentes na anatomia tipográfica

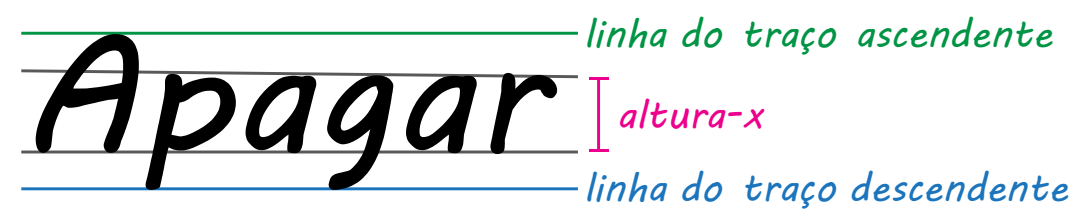

Fonte: da autora 
Nos anos 20, o procedimento de combinar palavras e imagens segundo a linguagem dos quadrinhos já estava tão cimentado que tornou-se possível cunhar humor fazendo paródia da própria mídia. Pat Sullivan incorporava bastante a metalinguagem para a comédia de sua obra, Felix the Cat, iniciada em 1922. Na Figura 21, temos o protagonista felino conferindo solidez ao algarismo que, na história, deveria ser tratada como uma contagem sonora. Essas brincadeiras com elementos que habitualmente interpretamos como incorpóreos foram extraídas para sua versão animada, lançada em 1953.

Figura 21. Felix the Cat, por Pat Sullivan, 1927

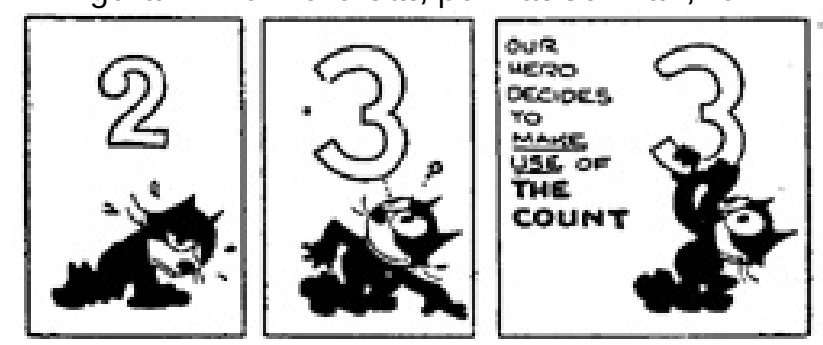

Fonte: http://felix.goldenagecartoons.com/ (2014)

O poder expressivo das letras enfim começou a ser notado para as narrações. Roy Crane desbravou esse potencial em Wash Tubbs, iniciado em 1924, aplicando negrito e esbanjando pontos de exclamação para acentuar as emoções de seus personagens. (Figura 22) Antes os efeitos onomatopaicos apareciam poucas vezes, agora Crane lhes auferia destaque visual, lançando um "ker-splash" ou um "lickety-wop" junto com outros sons mais comuns. (DeForest, 2004, p. 116)

Figura 22. Wash Tubbs, por Roy Crane, 1933
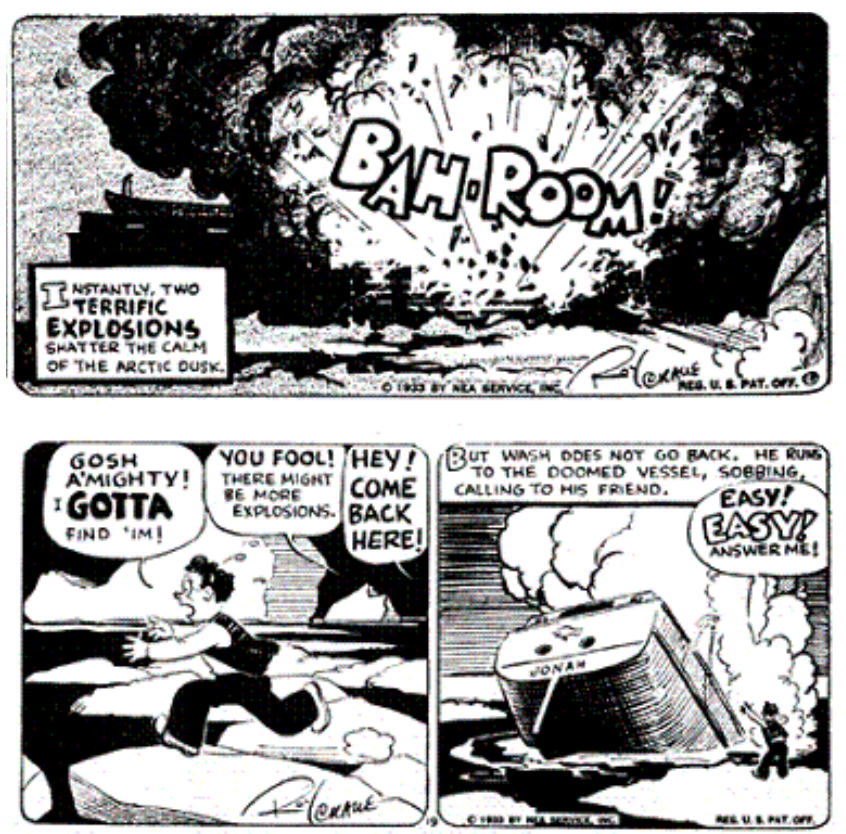

Fonte: http://ch999.blogspot.com.br/2009/11/wash-tubbs.html (2014) 
A difusão sonora não se restringiu apenas à mídia dos quadrinhos. Conforme chegava o fim da década, o cinema ia se despedindo de sua era silenciosa. Lefèvre (2006) compara os intertítulos dos filmes mudos com a separação entre as narrações e as imagens nas histórias em quadrinhos europeias. Com a introdução do meio sonoro na arte cinematográfica, quase que simultaneamente os europeus aceitaram que os personagens dos quadrinhos adquiriam voz por meio dos balões.

Um dos motivos foi a importação de quadrinhos americanos que aumentou massivamente. Outra razão foi a produção em países europeus de quadrinhos populares que utilizavam o balão: temos Bilderbogen des kleinen Lebens de Frits Garels na Alemanha (1924), Zig et Puce de Alain Saint-Ogan na França (1925), Kronblom de Elov Persson na Suécia (1927), Tintin de Hergé na Bélgica (1929) e Tobias Seicherl de Ladislau Kmoch na Áustria (1930). (Lèfevre, 2006)

Outros países ainda relutavam para encapsular seus textos em balões. A revista brasileira O Tico-Tico mantinha uma posição conservadora quanto ao formato de suas histórias e insistia no uso de caixas narrativas sob as ilustrações. Algumas páginas continham trabalhos importados, como os quadrinhos Disney, mas tinham seus balões removidos e os diálogos eram substituídos pela prosa, para manter o padrão local. (Moya, 1996, p. 83) A Figura 23 mostra a edição das tiras Mickey pela revista, sob o nome As aventuras do camondongo Mickey. $\mathrm{Na}$ arte original trazida dos Estados Unidos, havia balões, os quais deram lugar às transcrições ao rodapé de cada quadro.

Figura 23. O camondongo Mickey, por Walt Disney, editado por O Tico-Tico, 1937

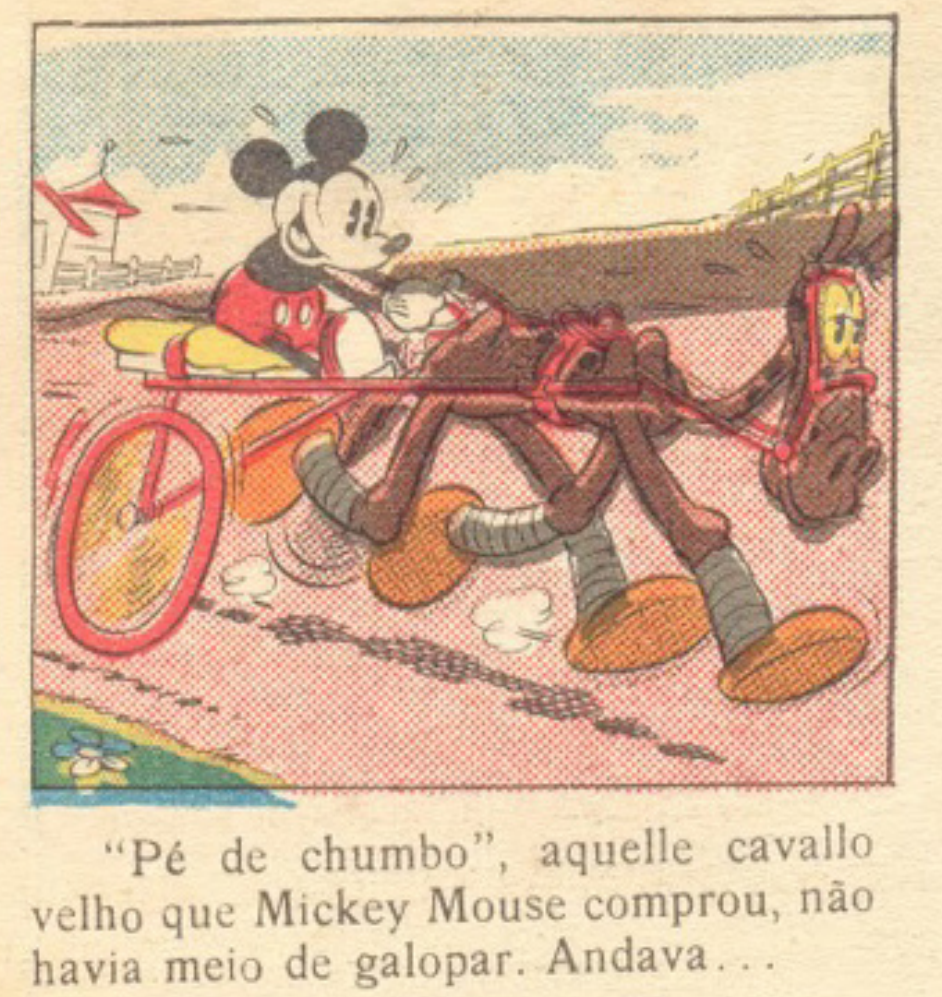

Fonte: http://museudosgibis.blogspot.com.br/2012/01/o-tico-tico-e-o-ratinho-curioso.html (2014) 
Sob influência de Little Nemo, o desenhista Max Yantok começou a inserir alguns balões em seus trabalhos para a revista O Tico-Tico, a partir de 1926. (Figura 24) O rabicho era indefinido e o contorno fugia ao padrão globular, mas o estilo foi inovador na revista onde predominava a narração em terceira pessoa.

Figura 24. Kaxinbown e Pipoca, por Max Yantok, 1930

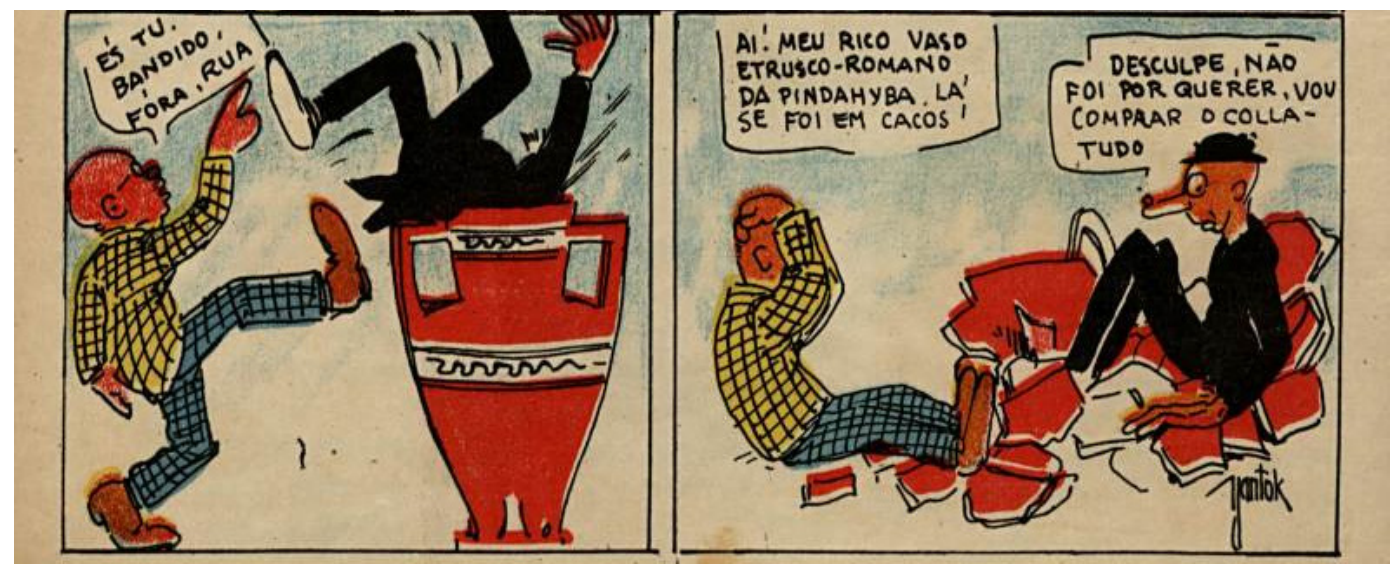

Fonte: Fundação Biblioteca Nacional (2014)

\section{PRIMEIROS GIBIS}

Enquanto a ideia do balão estava enfim sendo divulgada por um trabalho brasileiro, os trabalhos norteamericanos estavam bem mais avançados, com a promessa de consolidá-la na mídia. Em 1933, Maxwell Gaines decidiu fazer uma experimentação vendendo compilações das tiras dominicais publicadas pela Eastern Color Printing, em Connecticut, com a redução do tamanho das páginas em mais da metade, permitindo maior portabilidade. O sucesso foi de tal grandeza que a produtora decidiu lançar uma série regular chamada Famous Funnies já no ano seguinte, tornando-a o primeiro gibi existente. (Van Lente; Dunlavey, 2012, p. 27-28)

O preço módico de dez centavos por edição impulsionou a popularidade do formato, o que acarretou no crescimento da demanda por material para fomentar a indústria de revistas de quadrinhos que acabava de nascer. Percebendo essa tendência, o designer Howard Trafton desenvolveu a Cartoon, (Figura 25) uma fonte tipográfica informal inspirada nas tirinhas, fácil de ser lida e de ser diferenciada dos textos dos jornais, que preservava a organicidade da escrita à mão. Foi a primeira fonte a refletir o estilo dos quadrinhos e a primeira a usar apenas maiúsculas, além de ser considerada a representante do lettering dos quadrinhos por excelência. (Heller, 2002, p. 79) 
Figura 25. Versão light da fonte tipográfica Cartoon, criada por Howard Trafton, 1936

\section{ABCDEFGHIJKL MNOPQRSTUVW $X Y \& Z$ 1234567890}

Fonte: http://luc.devroye.org/hutchings/cartoon_light-medium.jpg

No entanto, a impressão das imagens e dos textos consistiam em dois procedimentos diferentes, além de encarecer a produção, então as letras continuaram sendo escritas manualmente.

Os cartunistas rapidamente ficaram sobrecarregados e não davam conta de todo o processo, o qual foi quebrado em etapas de linha de montagem. Assim, assistentes já eram requisitados para efetuar o emprego de textos. Bradley (2014) considera que "essa nova área de especialização teve um impacto imediato e duradouro no look and feel dos quadrinhos". Contudo, como um ofício que ainda estava em seus primeiros passos, as melhorias nessa época restringiram-se à legibilidade das letras e à formatação da mancha textual.

O surgimento dessa função se encontrava dentro dos limites estadunidenses e lá permaneceu por muito tempo, pois o mercado mundial de quadrinhos se abastecia principalmente dos trabalhos ianques, não havendo a necessidade de profissões tão específicas em outros países.

A importação levou a revista de quadrinhos à Europa no mesmo ano em que começou nos Estados Unidos: em 1934, foi lançado Le journal de Mickey. Essa reedição semanal das aventuras traduzidas do rato da Disney foi modelo de imitação para publicações que cobriram o continente, incluindo Spirou na Bélgica e Robbedoes na Holanda. No entanto, quando o Terceiro Reich conquistou a Europa Ocidental no início dos anos 1940, os alemães prontamente cortaram todas as importações americanas. (Van Lente; Dunlavey, 2012, p. 145-147) A propagação do balão, que se dava por meio dos quadrinhos estadunidenses, sofreu uma suspensão e, por muitos anos, esse recurso foi menos comum na Europa que nos Estados Unidos, ou era usado junto com blocos de texto. Na Holanda, em particular, a proibição alemã, somada à escassez de papéis para impressão e ao choque geral da guerra, pode ter contribuído para que a produção nacional se mantivesse conservadora às legendas, que foram a forma favorita local por mais duas décadas.

Voltando a 1937, os Estados Unidos prosseguiam explorando esse ramo próspero. O editor Vin Sullivan escolheu Superman para ser o destaque de seu novo 
projeto, a revista Action Comics. A obra de Jerry Siegel e Joe Shuster obteve uma brilhantura inesperada: o que havia sido cancelado por ser tachado como ridículo pelo editor Harry Donenfeld, demonstrou tamanha procura pelo público que foi retomado para ter presença permanente na revista. Iniciou-se aí o universo dos super-heróis e o marco inicial da Era de Ouro dos Quadrinhos.

Segundo Reed (2006), os logos até então eram "grotescos, rabiscados à mão em sua maioria. Em termos de qualidade, eles variavam do pouco competente ao hediondo". (tradução da autora) Em Superman, o título era desenhado por Joe Shuster, que não era tipógrafo nem sequer um designer gráfico. Contudo, a inconsistência gráfica das letras trazia um logo diferente a cada edição até que, no quinto volume da série, Ira Schnapp foi encarregado de refinar o desenho para a versão que se manteve inalterada até 1983. (Reed, 2006)(Figura 26)

Figura 26. Logo de Superman, por Ira Schnapp, 1940

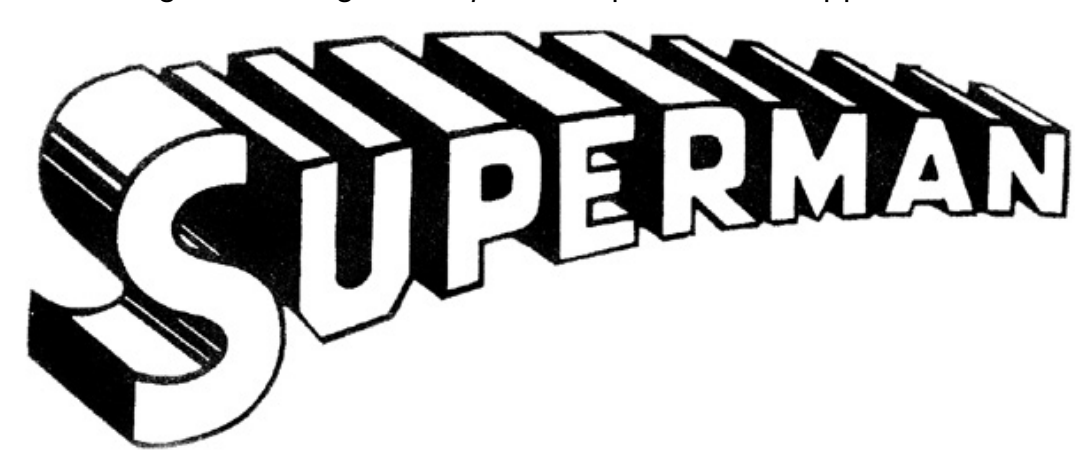

Fonte: http://www.dialbforblog.com/archives/374/

Como os quadrinhos são um meio visual, a atratividade do título na capa e sua representatividade das características da história eram essenciais para os potenciais compradores, principalmente as crianças, que reagiam visceralmente. Assim, o valor do serviço de Schnapp foi reconhecido a ponto de ser requisitado para vários outros heróis da Detective Comics (DC), como The Flash, Green Lantern, The Atom, Hawkman e The Justice League of America. Apesar dos seus inúmeros trabalhos, essa era uma época em que a excelência das letras não era importante o suficiente para que o nome de Ira aparecesse nas revistas. Em seus 50 anos trabalhando para a DC, Ira Schnapp foi creditado uma única vez, na sexta edição de Inferior Five. (idem)

Schnapp não apenas auferia qualidade aos títulos, como era também incumbido dos anúncios no interior das publicações. Cada texto era sempre feito à mão. Sobre a preferência da DC pelo processo manual, Reed (2006) explica que:

Em 1940, e até o advento do computador pessoal nos anos 1980, a tipografia foi um processo longo, complicado e difícil. Foi também muito caro. Eram necessárias toneladas de maquinaria cara e papéis especiais exóticos, sem mencionar um lago cheio de produtos químicos nocivos que 
"transformavam" o tipo em um processo similar à forma como o filme fotográfico desenvolve.

(tradução da autora)

Obviamente, Superman não foi uma obra notável dos quadrinhos somente por introduzir Schnapp nessa área. Em 1940, todo aspirante a quadrinista tentava a sorte copiando a fórmula de super-herói. Naquele ano, houve 150 lançamentos de novas histórias. (Van Lente; Dunlavey, 2012, p. 37)

Lefèvre (2006) aponta que foi nos anos 40 que os balões deixaram de ser exclusivos dos quadrinhos cômicos e passaram a invadir os gêneros de aventura e de ação. Entretanto, mesmo que esse elemento de fala fosse quase onipresente, alguns autores ainda se opunham ao uso dos balões. HQs clássicas, como o Príncipe Valente e Flash Gordon, mantinham o apego às legendas isoladas do desenho. (Patati; Braga, 2006, p. 22)(Figura 27)

Figura 27. Príncipe Valente, por Hal Foster, 1939

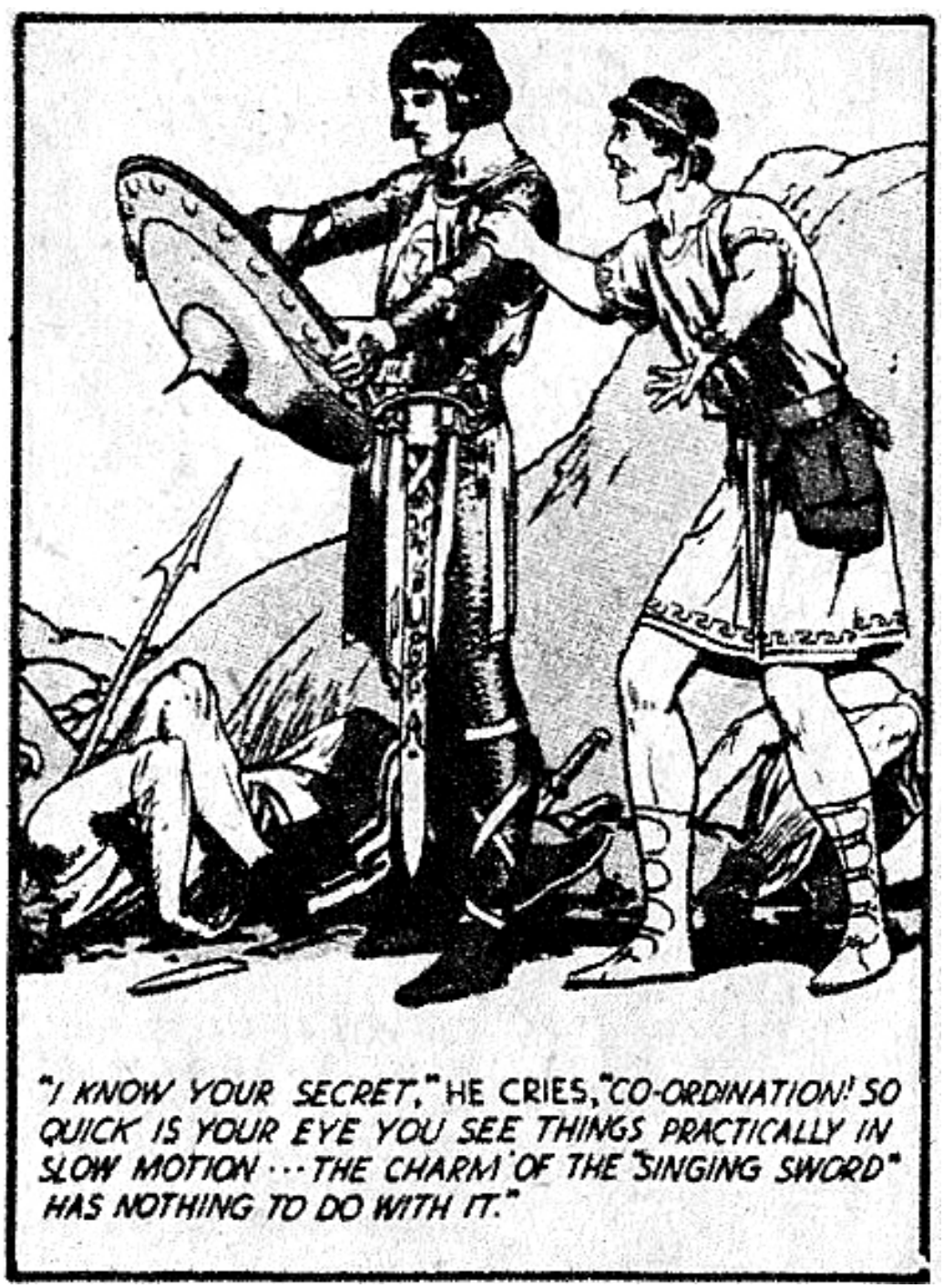

http://aprincenamedvaliant.blogspot.com.br/2011_04_01_archive.html 
Foi nesse mesmo período que o negrito estava começando a substituir o sublinhado para o destaque de palavras. Além disso, os balões de pensamentos em nuvem para os pensamentos já estavam dando seus primeiros passos:

Figura 28. Representações de pensamento em Superman, em 1943

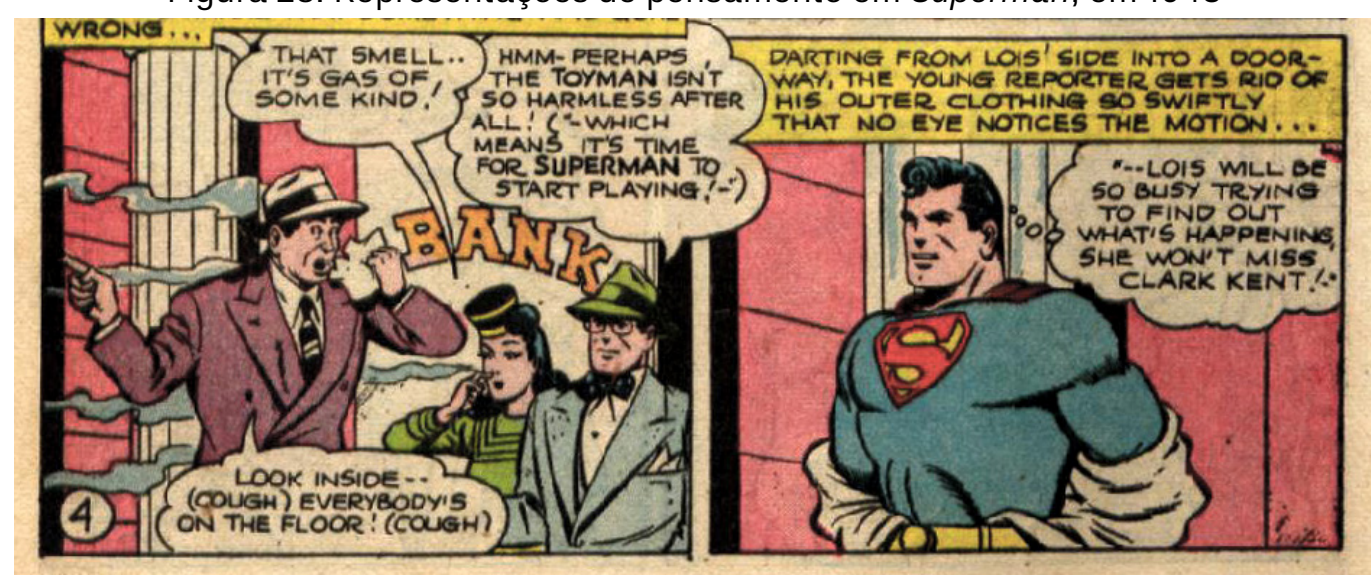

Fonte: SIEGEL; SCHUSTER, 1943, p. 4

No primeiro quadro, o personagem Clark Kent tem seu monólogo interno inserido no próprio balão de fala, entre parênteses, aspas e hífens. Até então, essa era a tradição adotada na obra. (Bell, 2010) Logo no segundo quadro, há uma das primeiras introduções do novo tipo de balão. Como o público ainda não tinha familiaridade com o formato, as aspas e os hífens foram utilizados para deixar clara a intenção do texto de representar o pensamento.

Percebe-se também que a tosse incluída na fala do personagem com um lenço está entre parenteses. Para indicar sons humanos como esse, caracterizados por serem causados por inalação ou aspiração de ar, com pouca ou nenhuma vocalização, um sinal diferente estava para surgir.

Figura 29. Suspiro ladeado por traços curtos em Wildman, por Bill Finger e Irwin Hasen, em 1942.

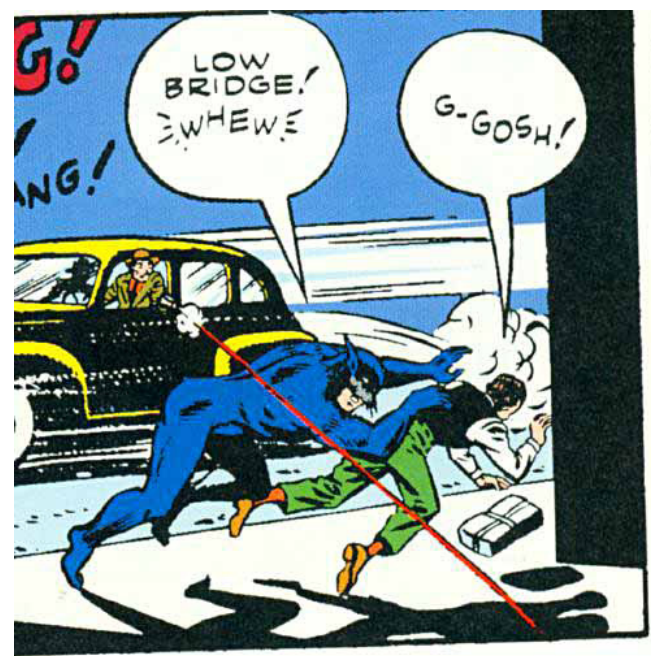

Fonte: http://kleinletters.com/Blog/punctuating-comics-breath-marks/ (2014) 
A Figura 29 mostra uma das primeiras tentativas de diferenciar a interjeição do resto da fala no mesmo balão. Pequenos riscos são colocados à esquerda e à direita da palavra "whew" ("ufa" em português). Klein ${ }^{3}$ apresenta uma teoria de que esses riscos derivaram de uma quebra dos parênteses em pontos ou em traços, da mesma forma que o balão de fala foi fragmentado e passou a ser tracejado para sugerir sussurros. Então, alguns letreiristas passaram a fazer essas marcas irradiando da palavra e o número de traços foi reduzido e padronizado para três de cada lado, configurando a chamada marca de respiro.

Klein (2014) constata também algumas tiras dessa década que fizeram uso de tipos no lugar da caligrafia, como o caso de Barnaby, de Crockett Johnson. O texto era provavelmente impresso conforme as especificações do autor, depois recortado e colado sobre os respectivos balões. Como os balões de Crockett possuíam formato mais retangular, era possível alinhar o texto à esquerda, em vez de centralizá-lo, facilitando a formatação.

Figura 30. Uso de tipos na tira Barbany, de Crockett Johnson, em 1943
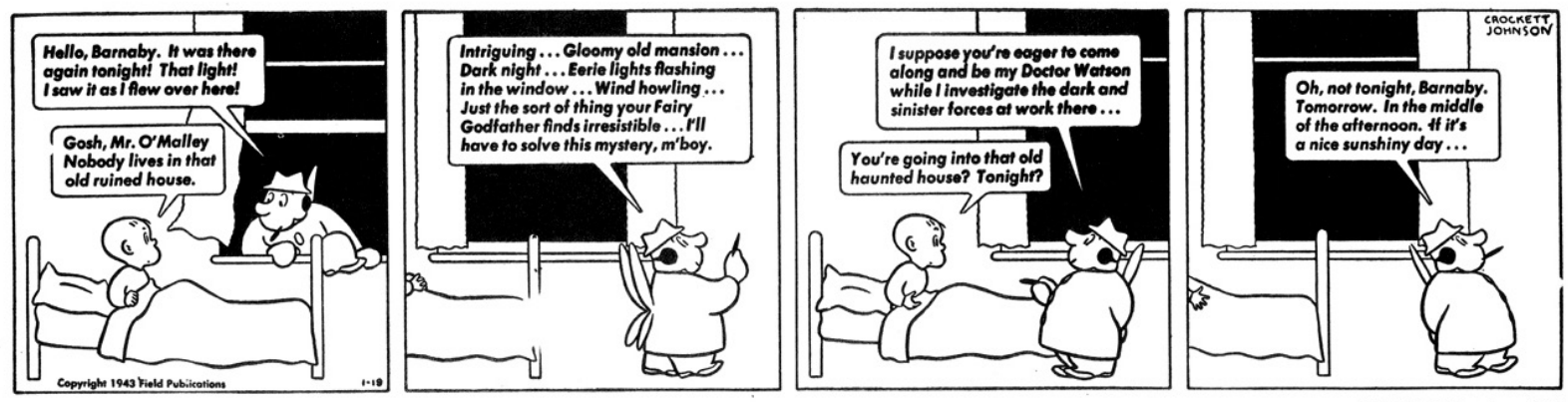

Fonte: BLACKBEARD; WILLIAMS, 1978.

Com a explosão da indústria de quadrinhos no cenário americano, a ideia dos balões rapidamente foi disseminada. Outra consequência da popularização da mídia foi que a procura por material novo permitiu que os cartunistas se especializassem apenas nos aspectos da criação em que eram melhor qualificados, tornando possível ganhar a vida sendo letreirista. (Bradley, 2014)

Esse processo de criação deu início às chamadas “lojas" (shops, no original), que eram estúdios formados por arte-finalistas, letreiristas, coloristas e outros profissionais especializados. As principais motivações das editoras eram econômicas, sem interesse de proteger os quadrinhos como um meio de expressão, então a publicação se concentrava na produção, e não na criação. Era comum contratarem quadrinistas renomados para escreverem os scripts, que descreviam a ação à esquerda e o diálogo à direita do papel. Estes eram mandados para as lojas, onde os membros trabalhavam implacavelmente para finalizar a história, recebendo em troca remuneração baixa e injusto anonimato. (Van Lente; Dunlavey, 2012, p. 39)

3 KLEIN, T. Punctuating comics: breath marks. Klein letters, mar. 2010. Disponível em: <http:// kleinletters.com/Blog/punctuating-comics-breath-marks/>. Acesso em: nov. 2014. 
Mesmo depois de a indústria de quadrinhos dispensar os serviços das lojas e começar a montar equipes próprias, a natureza colaborativa da produção impedia qualquer reconhecimento dos papéis individuais no processo criativo. (Nyberg, 1998; p. 159-160)

Devido ao pouco prestígio dado aos quadrinistas, era constrangedor estar envolvido com a produção de quadrinhos. O cargo valia a pena apenas para quem trabalhava em sindicatos, os quais funcionavam como agências responsáveis pelas publicações em jornais e pelos direitos autorais no caso de reedições.

Um nome que ganhou prestígio com quadrinhos sindicalizados foi Will Eisner, a quem foi dada a oportunidade de fazer um suplemento dominical em 1940 para jornais que queriam aproveitar a tendência Superman. A plasticidade e versatilidade do estilo de Eisner fizeram de sua obra, The Spirit, um novo padrão para a sofisticação na mídia. (Van Lente \& Dunlavey, 2012; 35) "Eisner jamais repetiu a logotipia de seu personagem na abertura de um episódio sequer. Todas, ou quase, apaixonavam." (Patati; Braga, 2006, p. 89)

Figura 31. Página de abertura de The Spirit, por Will Eisner, 1950

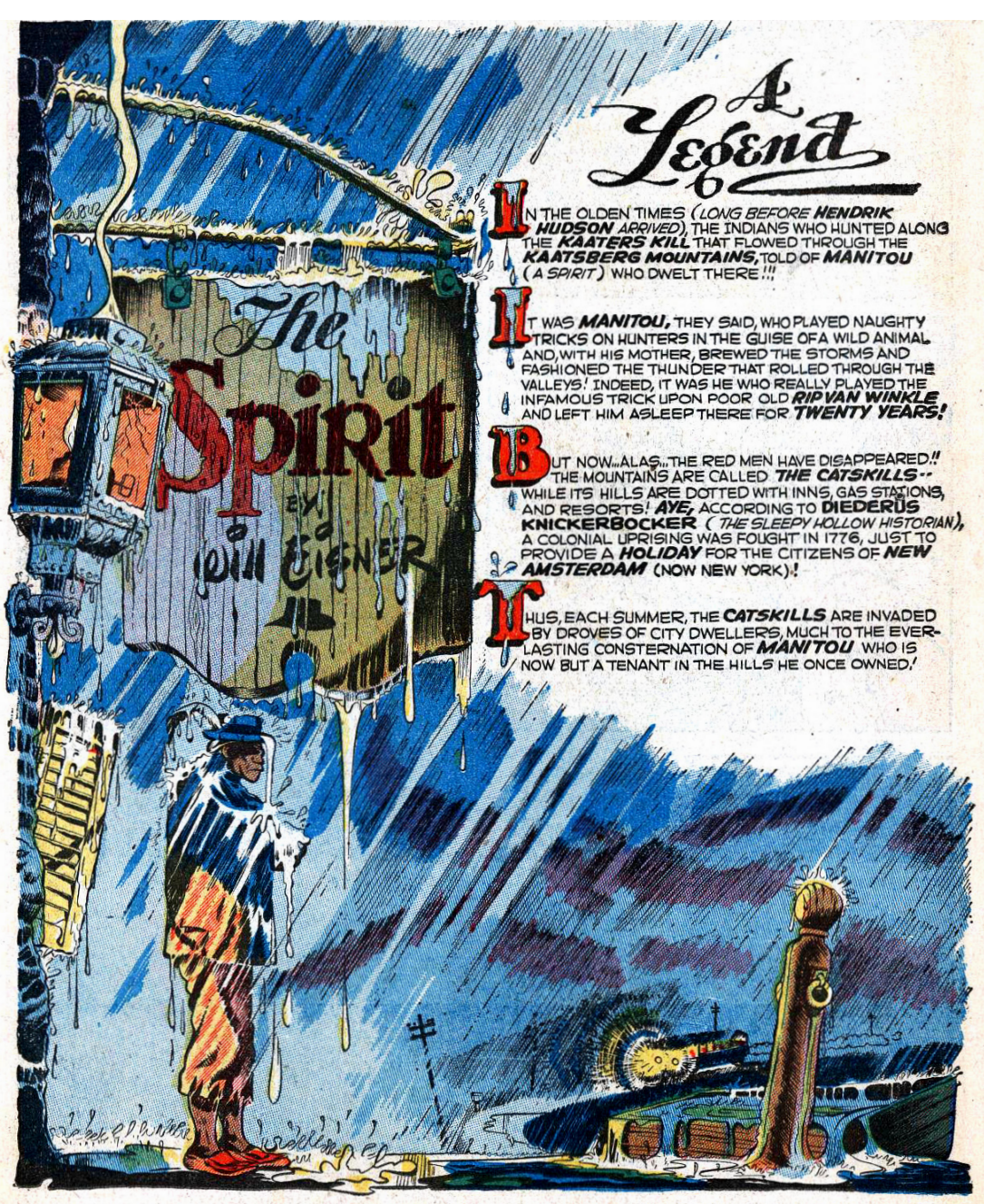

Fonte: EISNER, 1950, p. 3 
Com a quantidade limitada de páginas por publicação, o autor preferia inserir o título na primeira página da história do que sacrificá-la em prol de uma capa. Eisner trabalhou com colaboradores renomados na área do letreiramento, como Abe Kanegson e Ben Oda, mas era sempre ele mesmo que concebia o design único para o título de cada capítulo, As aberturas, longe de serem ordinárias, consistiam em ilustrações onde o nome da série encontrava-se desenhado como parte do cenário de alguma maneira fascinante. A inscrição "The Spirit" poderia aparecer em um cartaz ao fundo, em uma placa de madeira (Figura 31), em uma sucessão de marcas de batom, nas ondas de um redemoinho, na calha de drenagem escorrendo em um esgoto ou mesmo deletreado em tiras de papel volantes. Soluções inovadoras e criativas não faltavam, e, além de atraírem novos leitores, serviam também de inspiração para quadrinistas adaptarem as ideias a seu próprio gosto.

Seu esmero pelo desenho das letras ultrapassava um mero capricho: para ele, o letreiramento possuía uma importância maior do que uma simples etapa dos quadrinhos; era um processo que integrava a arte. (Eisner apud Inge, 2011, p. 56)

Eu sempre exigi um letreiramento imaginativo porque eu considerava-o como uma parte vital da arte, parte integrante da história, não como um mal necessário. Eu buscava alcançar efeitos sonoros com algumas letras feitas pesadamente em negrito, algumas levemente, algumas em diferentes estilos, para acomodar a orientação da história.

(Eisner apud Inge, 2011, p. 148, tradução da autora)

Mesmo esse novo nível de primor não impediu que os quadrinhos estadunidenses sofressem árduas críticas. Em 1942, Matthew Luckiesh e Frank Moss conduziram estudos em histórias em quadrinhos e concluíram que a mídia falhava no teste de visibilidade. Os pesquisadores consideraram que as letras eram muito pequenas, a impressão e o papel eram de má qualidade, o texto era frequentemente colocado sobre fundos coloridos e os balões de fala não tinham espaços apropriados entre as linhas de diálogo. Embora atualmente revisões posteriores dessas pesquisas revelem que os resultados foram exagerados, a constatação de que os quadrinhos simbolizavam um retrocesso para a visão das crianças teve forte impacto na época. (Nyberg, 1998, p. 11)

Simultaneamente, a Europa era cada vez mais reprimida pelo regime fascista, principalmente no que tange à resistência às influências culturais americanas. Com o problema de ainda circularem quadrinhos norteamericanos disfarçados de publicações nacionais, a ditadura favoreceu o uso de textos narrativos; na Itália, acabou sendo proibido o uso de balões. No fim de 1943, até o uso de quadros havia sido banido. (Gori apud Lefèvre, 2006)

Por outro lado, a Segunda Guerra Mundial instaurou um novo nicho para as revistas em quadrinhos estadunidenses na Inglaterra, visto que era a leitura favorita dos soldados ali estacionados. (Van Lente; Dunlavey, 2012, p. 174) 


\section{BOOM MUNDIAL DOS QUADRINHOS}

Assim que a paz reinou novamente, eclodiram importações de quadrinhos dos Estados Unidos no mundo ocidental. (Patati; Braga, 2006, p. 180) Embora o protecionismo cultural implantado em alguns países não permitisse que as HQs estadunidentes retornassem de forma significativa, como aconteceu na França, o uso do balão logo se tornou uma técnica dominante. Curiosamente, alguns países em regimes comunistas mantiveram a proibição aos balões, como a Alemanha Oriental e a Hungria. (Lefèvre, 2006)

O Japão se inundava da cultura ocidental. A derrota na Segunda Guerra resultou em um período de miséria, onde a diversão barata ajudava a esquecer a angústia cotidiana. (Luyten, 2012, p. 19) A busca por novas fontes de entretenimento a baixo custo abriu caminho para os akai hon, livretos alternativos impressos em papel barato. Foi nesse caminho que surgiu o primeiro mangá de Osamu Tezuka, considerado hoje como o deus das histórias em quadrinhos. (Van Lente; Dunlavey, 2012, p. 198) Sua obra de estreia, Shin Takarajima (traduzido como "A nova ilha do tesouro"), trazia consigo a influência do estilo Disney e da cenografia cinematográfica, como closes e expressões tridimensionais. (Ban, 2004, p. 29) Soma-se a isso a moldagem das onomatopeias e Tezuka deu origem a uma narrativa que se assemelhava a um filme, com um traço que ditou o estilo visual do mangá por pelo menos uma década.

Em Shin Takarajima, Tezuka aproximou os elementos do letreiramento aos elementos do cinema. Na Figura 32, o balão é posicionado na boca do personagem para intensificar seu grito, de efeito semelhante ao causado pela agitação da úvula nos desenhos animados. Na Figura 33, a onomatopeia atravessa quadros como um som que acompanha o decorrer da ação.

Figura 32. Uso de balão em Shin Takarajima, por Osamu Tezuka, 1946

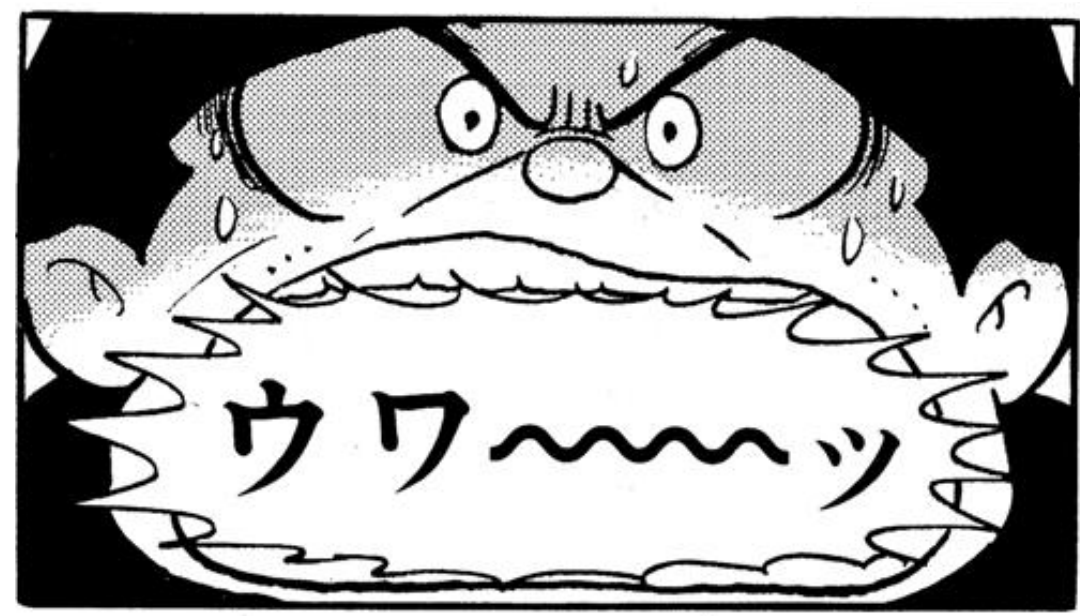

Fonte: Shin Takarajima, publicado por Akita Shoten, Tóquio 
Figura 33. Uso de onomatopeia em Shin Takarajima, por Osamu Tezuka, 1946
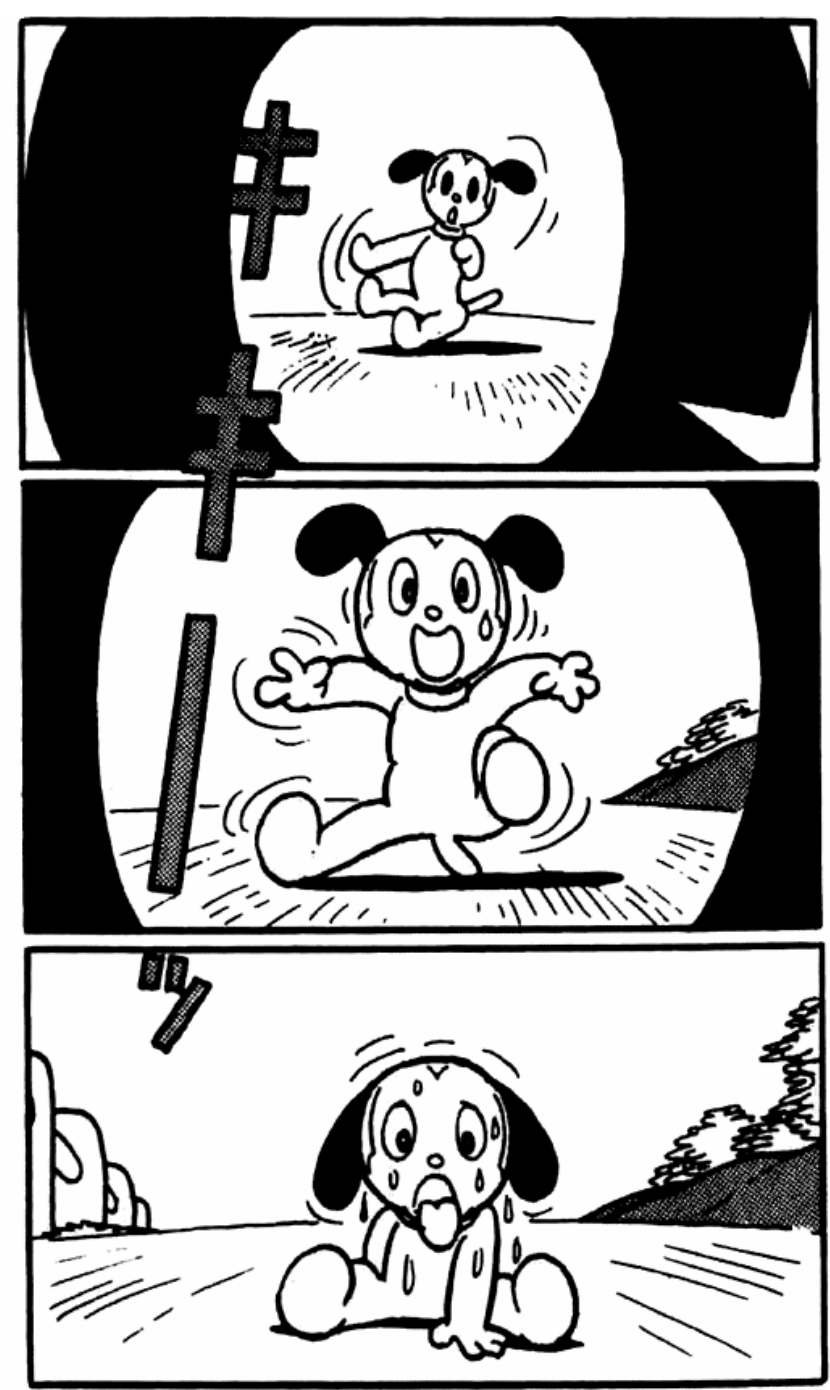

Fonte: Shin Takarajima, publicado por Akita Shoten, Tóquio

No Brasil, um grande passo também foi dado em relação à dinamicidade dos quadrinhos, a qual não era muito aproveitada em várias adaptações literárias. Na maioria das vezes, a massa textual nas legendas era tão densa que as imagens apenas ilustravam as cenas, porém, isso mudou com a chegada do haitiano André LeBlanc, antigo assistente de Will Eisner. A esposa de LeBlanc colaborava na montagem do roteiro e procurava respeitar a quantidade de texto por quadro - o que consistia em um verdadeiro desafio, dado o volume de passagens narrativas que precisava ser suprimido. (Patati \& Braga; 190) André se encarregava de todo o resto do trabalho, incluindo a decupagem e a definição dos diálogos. Apenas as letras eram colocadas pela editora.

Logo em seu primeiro serviço, O Guarani, de José de Alencar, a dupla conseguiu mostrar que a redução de textos narrativos contribuíam para um ritmo mais fluido, em que as próprias imagens contavam a história. (Figura 34) 
Figura 34. Adaptação de O Guarani, por André LeBlanc, 1950

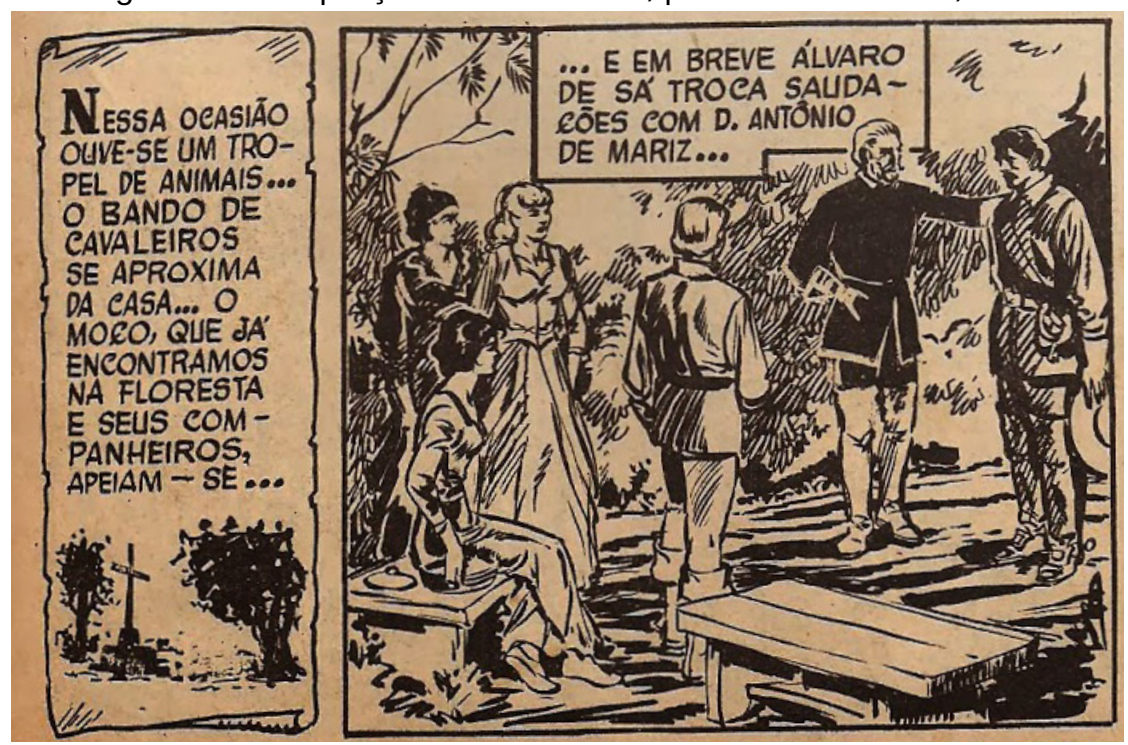

Fonte: http://historiaequadrinhos.blogspot.com.br/2013/09/ (2014)

Em várias partes do mundo, quadrinistas faziam experimentações com a interação entre palavra e imagem. Walt Kelly se torna marcante nesse meio ao explorar os tipos caligráficos e ligá-los às personalidades de seus personagens em Pogo. $\mathrm{O}$ formato do balão e a configuração gráfica textual tornavam o conteúdo e o falante ainda mais expressivos e característicos.

O personagem conservador Deacon Mushrat se expressa em escrita gótica, a qual reforça o apego por arquétipos antigos. Os balões de seu amigo Sarcophagus MabAbre são marcados pelo formato retangular e pelas bordas grossas, cujo conteúdo é em caligrafia manual, remetendo ao caráter íntimo de seu trejeito melancólico. As falas do tempestuoso P. T. Bridgeport assemelham-se a cartazes publicitários, com direito a pregos prendendo o balão, estilos de letra variados e símbolos típicos. (Figura 35)

Figura 35. Exemplo da fala de P. T. Bridgeport, personagem de Pogo, por Walt Kelly, 1948-1975

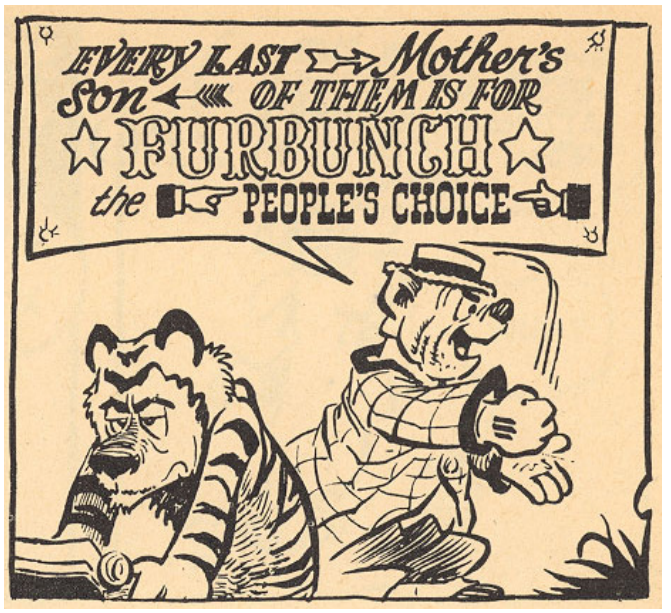

Fonte: http://www.fontbureau.com/blog/for-spring-hath-sprung-the-cyclotron/ (2014) 
A essa altura, a demanda por letreiristas era grande o bastante para que eles pudessem atuar como profissionais autônomos, ou seja, sem vínculo com estúdios ou companhias. Klein diz em seu blog ${ }^{4}$ que, nos anos 50 , famosos letreiristas como Gaspar Saladino, Sam Rosen e Ben Oda estavam bastante ocupados com tiras e páginas de quadrinhos para editoras como DC Comics, Marvel Comics e King Features. Cada uma estabelecia sua própria forma de trabalho.

$\mathrm{Na}$ DC, houve um mandato editorial exigindo artistas para rascunharem os balões de texto e efeitos sonoros diretamente na arte. Os letreiristas - como Todd Klein ou Gaspar Saladino - fariam seu trabalho antes que a página fosse passada para um arte-finalista que iria dar o acabamento em tudo. Nas capas, os letreiristas tinham total liberdade para colocar o texto onde achassem melhor. Essa não foi a única regra editorial para letras, embora as outras sejam mais difíceis de definir.

(Bradley, 2014, traduzido pela autora)

Outro método além da escrita manual começou a ser utilizado. Jim e Margaret Wroten inseriram texto em milhares de páginas pelo letreiramento mecânico, com o uso de um pequeno pantógrafo da marca Leroy. O sistema consistia em uma coleção de moldes e um riscador, sendo aplicado pela primeira vez nos quadrinhos pelo casal Wroten. (Stewart, 2011) Apesar da vantagem da uniformidade das letras, outros letreiristas consideravam o uso da ferramenta muito laborioso.

Figura 36. Uso do letreiramento Leroy em Wonder Woman, escrito por Charles Moulton, 1944
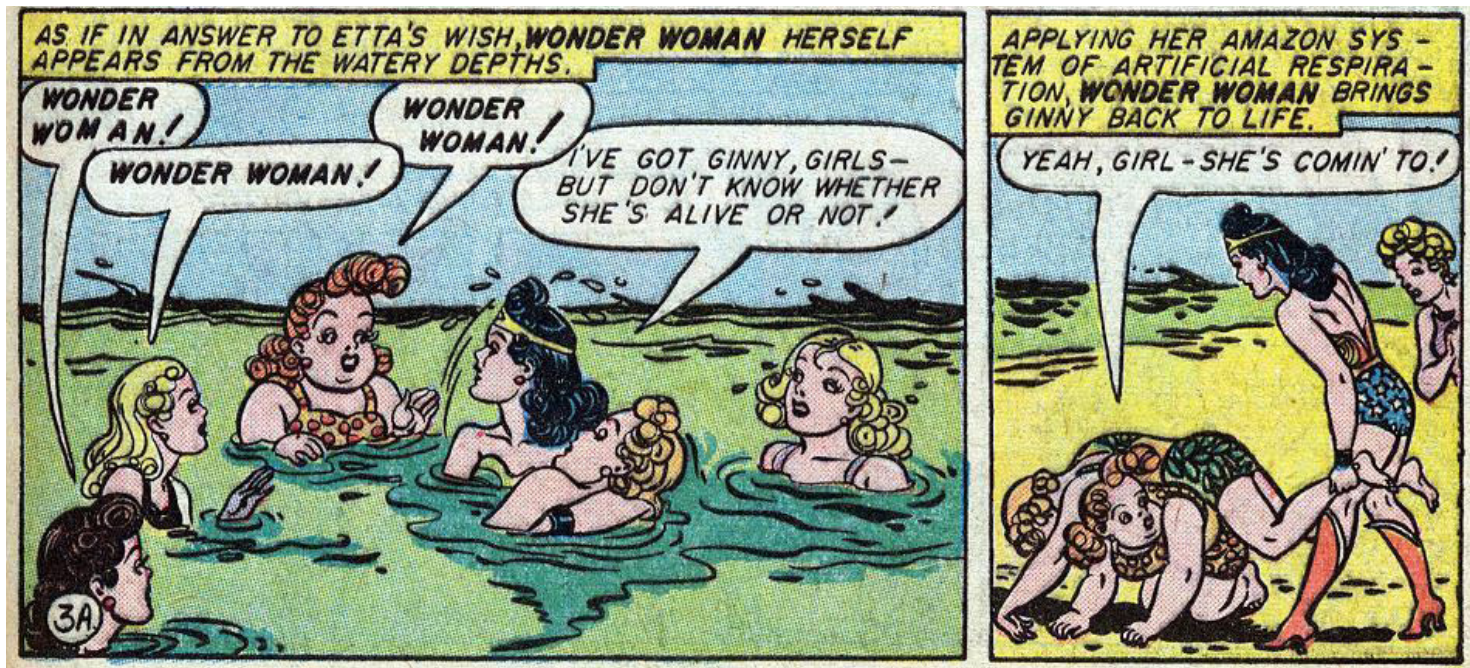

Fonte: MouLTon, 1944, p. 3 (letreirado pelo casal Wroten)

Como é possível verificar na imagem acima, havia uma tendência de usar negrito no nome de cada personagem, toda vez que ele aparecia. As editoras perceberam que era incoerente dar ênfase a isso continuamente e a moda não perdurou. $O$

4 http://kleinletters.com/LetteringTop.html (acesso em jul. 2013) 
uso descomedido do negrito, no entanto, foi conservado para realçar palavras, dado que o itálico era menos visível nas impressões de baixa qualidade.

Outro costume excessivo era o uso de pontos de exclamação, que se mostravam mais usuais do que os pontos finais. Humez e Humez (2008, p. 142) explicam que o ponto final tendia a desaparecer com as impressoras da época, mas os pontos de exclamação mantinham sua visibilidade. Além do uso nas falas e nos pensamentos, o símbolo aparecia também quando uma arma era disparada. Assim, especula-se $^{5}$ que seja por isso que os pontos de exclamação são chamados de "bang" em manuais sobre formatação, nos Estados Unidos.

Havia mais uma convenção de pontuação que se consolidava: o uso em demasia de dois hífens seguidos ("--"). Essa sinalização duplicada não era ortograficamente correta, então de onde surgiu? O letreirista Todd Klein explica que os roteiros eram digitados em uma máquina de escrever e a forma usual para indicar um travessão eme ("-") era com um par de hífens, já que não existia tecla específica para esse símbolo 6 . Os tipógrafos sabiam converter o hífen duplo para o travessão quando passavam um texto datilografado para a formatação de impressão, mas os letreiristas provavelmente desconheciam esse preceito e copiavam a pontuação exatamente como estava no roteiro. Assim, o traço duplo gradualmente tornou-se uma forma comum nas histórias em quadrinhos.

Nesse período, não apenas o aparelho Leroy estava sendo utilizado para padronizar as letras, como também a máquina fotocompositora, que funcionava como uma máquina de escrever com impressão mais limpa e que permitia o uso de várias fontes intercambiáveis. A máquina, que Klein (2014) cogita ser uma Varityper, foi largamente utilizada pela editora Charlton para inserir textos narrativos e balões. Os títulos e anúncios eram escritos com a Typositor, apropriada para imprimir letras maiores em rolo de papel fotográfico. Frequentemente, os créditos do letreiramento eram concedidos a "A. Machine", que pode ser traduzido como "Uma Máquina".

Figura 37. Títulos inseridos por Typositor e créditos à esquerda para "A. Machine"

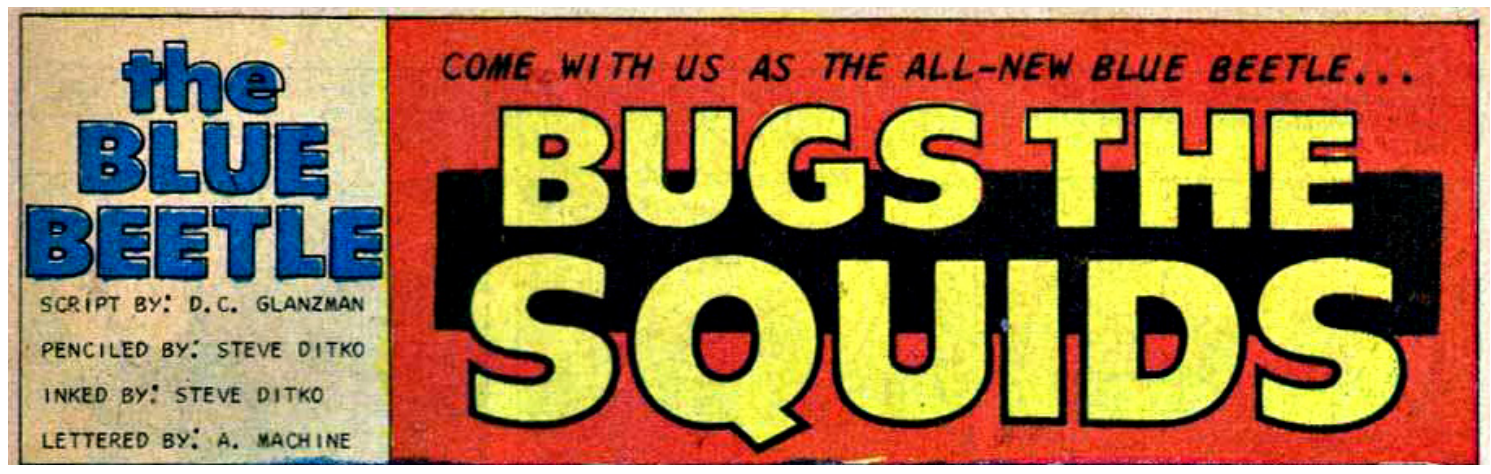

Fonte: DitKo, GLANZMAN, 1967, p. 1

$5 \quad$ Segundo The pronunciation guide, nov. 1995, disponível em <http://ascii-table.com/pronunciation-guide.php\#01>. Acesso em: ago. 2014.

$6 \quad$ KLEIN, T. Punctuation comics: dots and dashes. Todd's blog, set. 2008. Disponível em: < http://kleinletters.com/Blog/punctuating-comics-dots-and-dashes/>. Acesso em: nov. 2014. 
O artista Frank McLaughlin (apud Irving, 2000, p. 27) relata que a medida foi tomada para tentar cortar custos e que o editor executivo Pat Masulli havia desenvolvido uma fonte tipográfica semelhante às letras dos quadrinhos para as máquinas fotocopiadoras. O texto era colocado diretamente sobre a obra de arte. No entanto, McLaughlin afirma que "os resultados foram um desastre completo que causou muitos mais problemas do que resolveu."

Klein (2014) aponta o espaçamento entreletras como uma das desvantagens do uso da máquina, pois fazer esse ajuste poderia prolongar o trabalho a oito palavras por minuto, então, um excesso de espaço vazio circunda a letra $i$, por exemplo (Figura 38), e o espaçamento entrepalavras também é abundante.

Figura 38. Uso de máquina fotocompositora para textos em balões
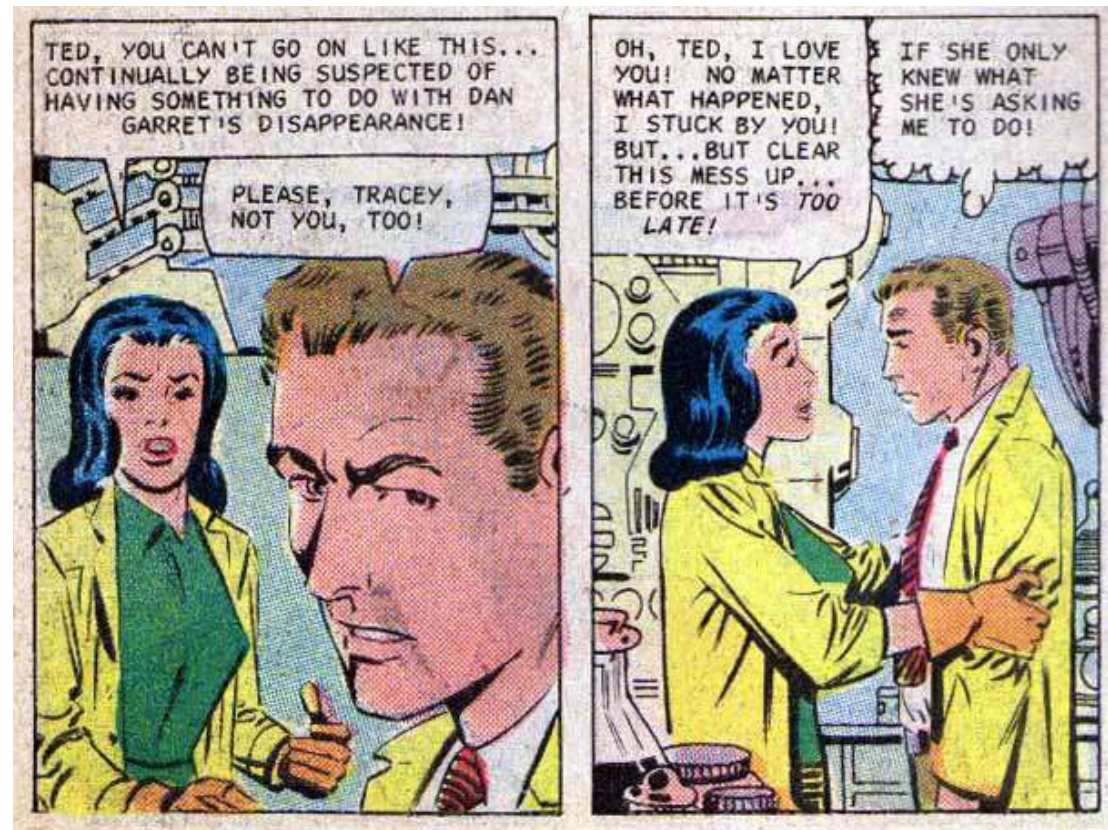

Fonte: DiTKo; GLANZMAN, 1967, p. 6

Mesmo que a aparência do texto não tivesse a semelhança desejada com a escrita manual, as fontes de Manulli foram usadas nos gibis da Charlton por alguns anos. Uma preocupação maior estava entrando em vigor.

Em 26 de outubro de 1954, a indústria de quadrinhos adotou o Comics Code Authority e deu início a quase 40 anos de auto-censura. O Código foi criado em resposta à reação pública contra a indústria de quadrinhos em geral, e foi implementado especificamente como resultado de receios dos editores sobre a regulamentação do governo. A indústria, então, passou a se auto-policiar através de um "código de ética e padrões" para quadrinhos. As histórias que fossem aprovadas pela inspeção recebiam um selo de aprovação. Apesar de o Comics Code Authority não possuir qualquer controle sobre as editoras, a maioria das distribuidoras se recusavam a portar quadrinhos sem o selo, cujo design foi ironicamente concebido por Ira Schnapp. 
Algumas das imposições do Código remetiam diretamente à formatação textual, como a regra de que a palavra "crime" nunca deveria aparecer sozinha no título nem ser maior do que as outras palavras da capa. Outras restrições interferiram na disposição gráfica com a censura do conteúdo. Enquanto algumas histórias eram reescritas e re-letreiradas conforme a correção, outras apenas cortavam a parte rejeitada, causando um claro desequilíbrio no balão. (Figura 39)

Figura 39. Jesse James após revisão do Código, por Everett Raymond Kinstler, 1955

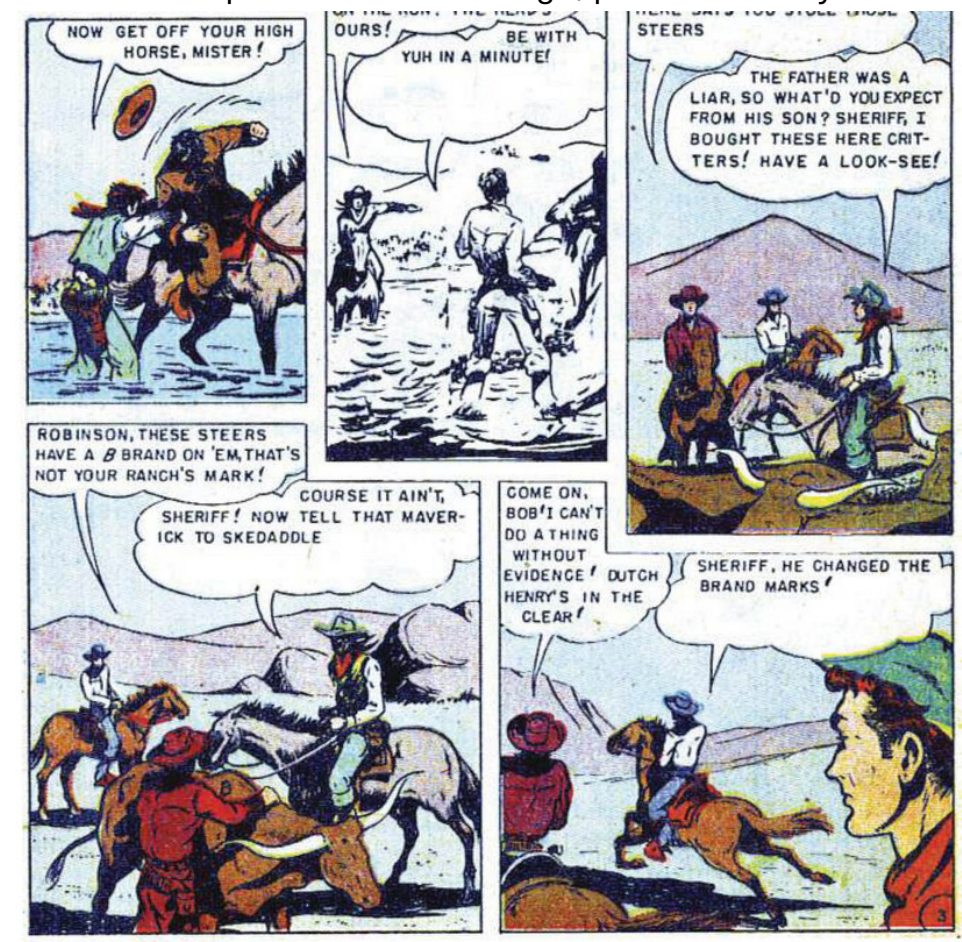

Fonte: http://cbldf.org/2012/08/tales-from-the-code-how-much-did-things-change-after-the-enactment-of-the-comics-code-of-1954/

A caçada aos quadrinhos se propagou para fora do continente: inúmeros educadores conservadores em todo o mundo atacavam essa mídia como algo prejudicial às crianças. No Japão, uma saída encontrada foi a criação dos gekiga por Yoshihiro Tasumi, em 1957, que consistiam em histórias mais maduras. Como o gênero era voltado para o público adulto, o gekiga conseguiu se livrar de acusações de tentar corromper as mentes infantis.

Tatsumi e outros mangakás (quadrinistas japoneses) estavam em uma busca de maior integração entre palavras e imagens, para que a ação a fosse lida mais rapidamente. Essa combinação harmoniosa se tornou possivel graças ao simples fato de que o mangaká era quem escrevia e desenhava suas próprias obras. Dessa forma, as ligações entre palavras e imagens eram concebidas de maneiras que eram muito mais difíceis para quadrinistas norteamericanos, que recebiam um script para trabalhar e, em seguida, tinham de mandar o trabalho para arte-finalistas e letreiristas. (Petersen, 2010, p. 198) 
O fim dos anos 50 e início dos anos 60 viu a história em quadrinhos se elevar do ponto de mídia corruptora ao conceito de arte: enunciava-se aí o nascimento da Pop Art. Roy Lichtenstein deu um passo para trás no tempo da impressão e voltou a usar cores primárias e estilos simplistas com as retículas Ben-day ${ }^{7}$ para enfatizar planicidade, banalidade e falta de individualismo em suas obras que se baseavam em cenas de histórias em quadrinhos. (Van Lente; Dunlavey, 2012, p. 119) As palavras em balões de fala tendiam a parecer mais altas e mais finas, criando uma impressão mais aguda. (Petersen, 2010, p. 196) O sucesso do estilo se deu pela reflexão da onda nostálgica da década, em que os consumidores haviam colecionado quadrinhos durante a infância e reviviam o hobby agora na fase adulta.

Ao passo que o movimento atingia seu auge em meados dos anos 60, franquias de quadrinhos passavam pela adaptação para a TV, incluindo Batman. O produtor de Batman, William Dozier, teve a idéia de torná-lo tão "careta" que os adultos achariam divertido. O público amou esse conceito, inclusive os brilhantes efeitos sonoros ao estilo Pop Art sobre as cenas de luta. (Figura 40)

Figura 40. Sequência de cenas do episódio The Bird's Last Jest da série Batman, 1966

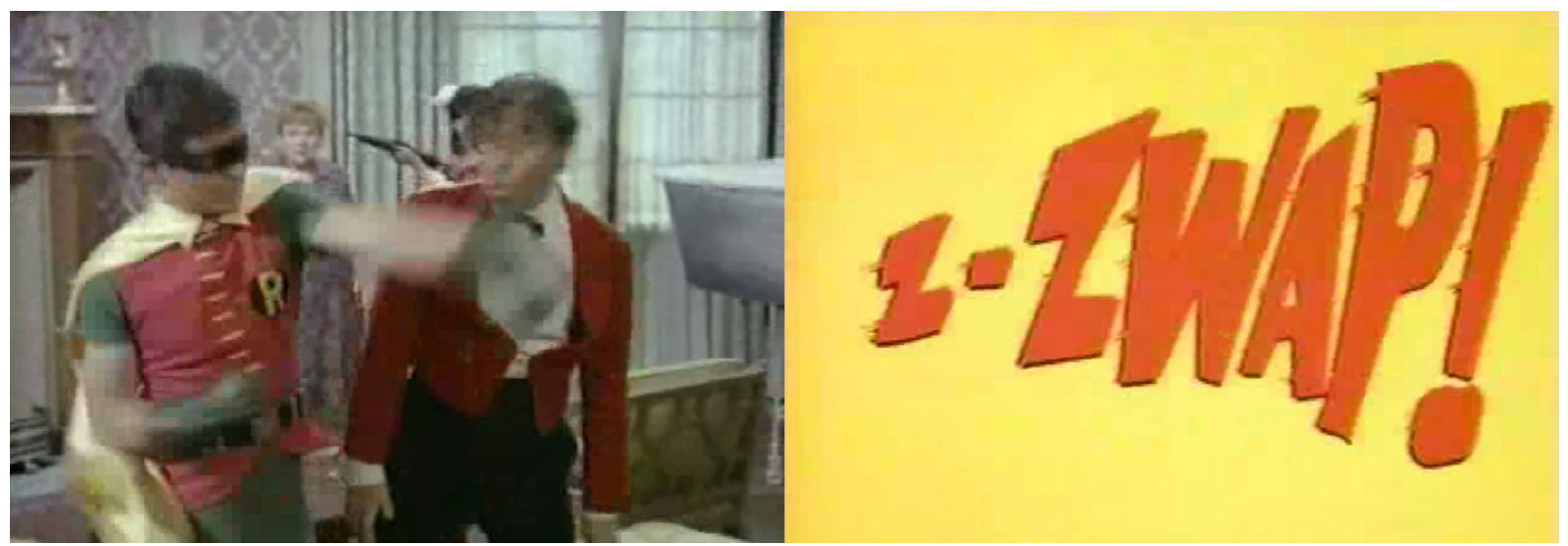

Fonte: https://www.youtube.com/watch?v=-EEyQIAemn0 (2014)

Os quadrinhos aproveitaram o sucesso que o movimento estava tendo entre os jovens e expandiram o público-alvo para abranger os universitários. As cores que inspiraram Lichtenstein foram intensificadas até tons mais extravagantes de turquesa, cereja e esmeralda. Procurando manter o que era visto pela audiência do Pop Art, os quadrinistas passaram a usar mais jogos de palavras e diálogos semeIhantes aos painéis de Lichtenstein. Os efeitos sonoros que o Pop fazia vibrar como palavra-imagem também foram copiados para o papel, aumentados e exagerados. (Brooke, 2005, p. 182)

Sob essa mesma influência, surgiram revistas de quadrinhos inglesas com títulos onomatopaicos, como Wham!, Smash! e Pow!. (Gravett, 2005) O design de cartazes, anúncios e grandes revistas seguia a marcha do Pop Art e aderiu ao estilo

$7 \quad$ Processo gráfico inventado por Benjamin Day no século XIX no qual pequenos pontos em CMYK são colocados próximos ou sobrepostos. 
típico de quadrinhos, ao ponto de adotar balões de fala e balões explosivos para transmitir mensagens comerciais.

As onomatopeias ganharam tal importância que as mais utilizadas eram usadas em construções frasais do dia-a-dia. Segundo Gardiner ${ }^{8}$, o Bamf, barulho do teletransporte do personagem Nightcrawler, em $X$-Men, virou verbo nos Estados Unidos: "to bamf out" foi emprestado pelos fãs para designar o teletransporte em geral.

Nos anos 60, outros métodos de trabalho em quadrinhos estavam em vigor. As letras deixaram de ser colocadas diretamente sobre a arte: agora predominava um modelo de recorte e cola, em que o desenhista tinha mais tempo para terminar uma edição, já que o arte-finalista e o letreirista poderiam trabalhar na página ao mesmo tempo. Esse processo muitas vezes resultava em sombras nas fotocópias, devido às partes coladas. Com isso, surgiu um novo membro da linha de produção de quadrinhos, chamado de "stripper". Ele era o responsável pelos pequenos retoques no filme fotográfico para remover as sombras ou quaisquer outras imperfeições. O serviço tinha que ser feito às pressas, a imagem era pequena e invertida, então às vezes, os pontos finais eram confundidos com sujeira e apagados. (Bradley, 2014) Mais um motivo para que os pontos finais devessem ser evitados.

Mesmo sob severa limitação da Comics Code Authority, alguns cartunistas estavam determinados a publicar conteúdo proibido. Esse desejo se concretizou em edições que pecavam pela desordem e até pela ilegibilidade, longe de serem sofisticadas. Era o movimento underground dos quadrinhos.(Mazur; Danner, 2014, p. 23)

No mundo das tiras tradicionais, as histórias em quadrinhos de super-heróis têm seu próprio estilo [de lettering] adequado ao assunto: sonoro, expressivo, e masculino. O mesmo é verdadeiro para as obras de guerra, horror e ficção científica, enquanto quadrinhos de romance usavam letras "femininas" com floreios e arabescos. Alguns estilos de letras são emblemas de seus temas, mas desde o advento dos Comix Underground no final dos anos 60, há ainda mais para se ver no lettering de quadrinhos do que relações óbvias e metafóricas. O lettering é realmente arte.

(HELLER, 2002, p. 75, tradução da autora)

Assim como vinha acontecendo no Oriente e na Europa, os autores dos gibis underground tinham mais autonomia sobre seus trabalhos por não dependerem do serviço de outros profissionais nem estavam amarrados ao gênero dominante no mercado. Em vez disso, o foco era na liberdade de expressão, o que encorajava uma diversidade de experimentações em várias áreas, inclusive a do lettering. O design dos títulos é incrivelmente diversificado, com grande influência psicodélica, de cartazes publicitários e do movimento hippie, que estava agora em seu auge.

8 GARDINER, Bryan. Boom! How comics book sounds become movie sounds. Disponível em: <http://gizmodo.com/5656616/thwip-snikt-bamf-how-comic-book-sounds-became-real-life-sounds>. Acesso em: jul. 2014. 
Segundo Heller (2002), no movimento, artistas mais conhecidos de São Francisco, como Robert Crumb e Victor Moscoso, eram fascinados pela escrita com serifas quadradas e por ornamentos curvilíneos da Art Nouveau, os quais não eram simplesmente copiados, mas manipulados para um estilo mais aplicável aos quadrinhos. A autora considera Rick Griffin como um dos letreiristas mais inovadores e visionários. Suas frases "costuradas" à nanquim são obras de arte que muitas vezes se elevam ao expressionismo puro, com misteriosos e múltiplos significados. (Figura 41) O design criado por Griffin para os textos dialogava com sua ilustração de maneira tão vívida que se tornava parte da arte.

Figura 41. Página 18 de Man from Utopia, por Rick Griffin, 1972

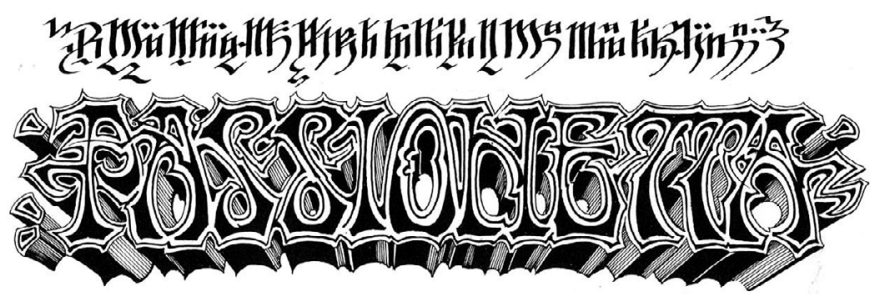

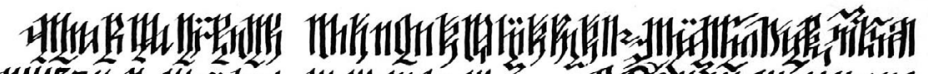

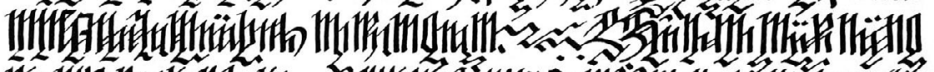

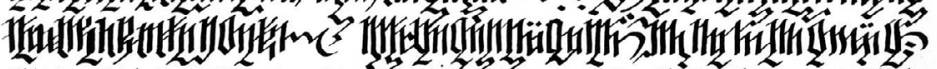

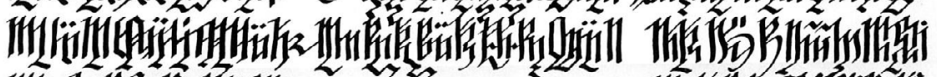

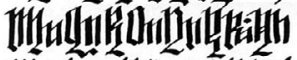

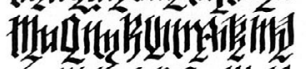

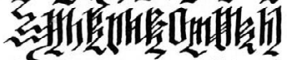

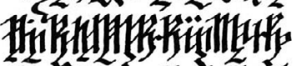

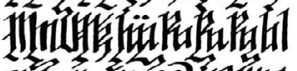

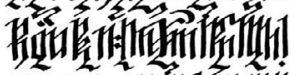

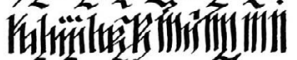

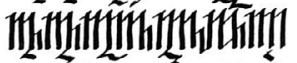

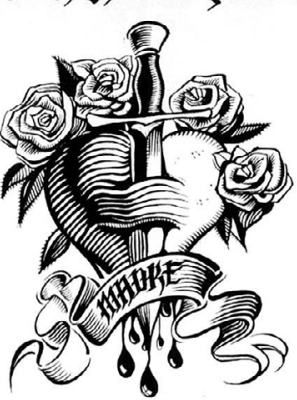

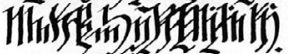

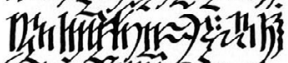

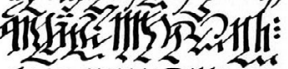

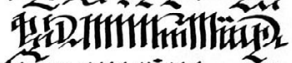

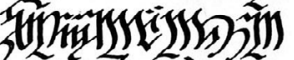

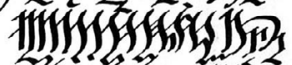

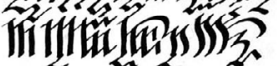

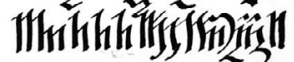

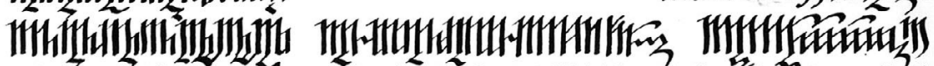

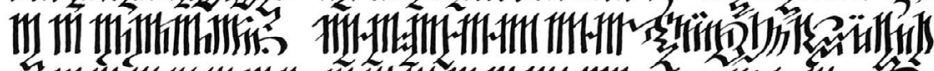

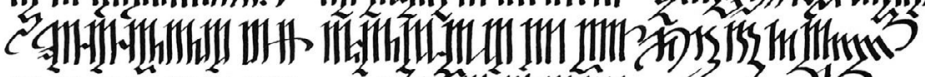

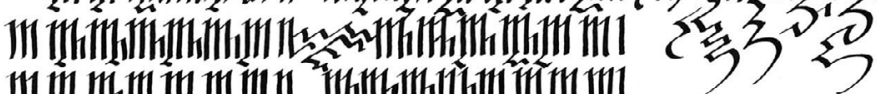

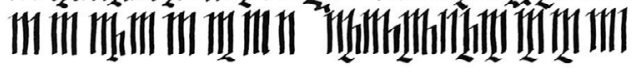


Outro nome importante do movimento underground é Vaughn Bodê. As formas grandes, exuberantes e arredondadas de suas letras, junto às cores vibrantes usadas, tiveram grande influência sobre a arte do graffiti. (Mazur; Danner, 2014, p. 39) (Figura 42) Copiar seus personagens e seu lettering se tornou um rito de passagem para alguns grupos de grafitti.

Figura 42. Capa de Cheech Wizard, por Vaughn Bodê, 1972

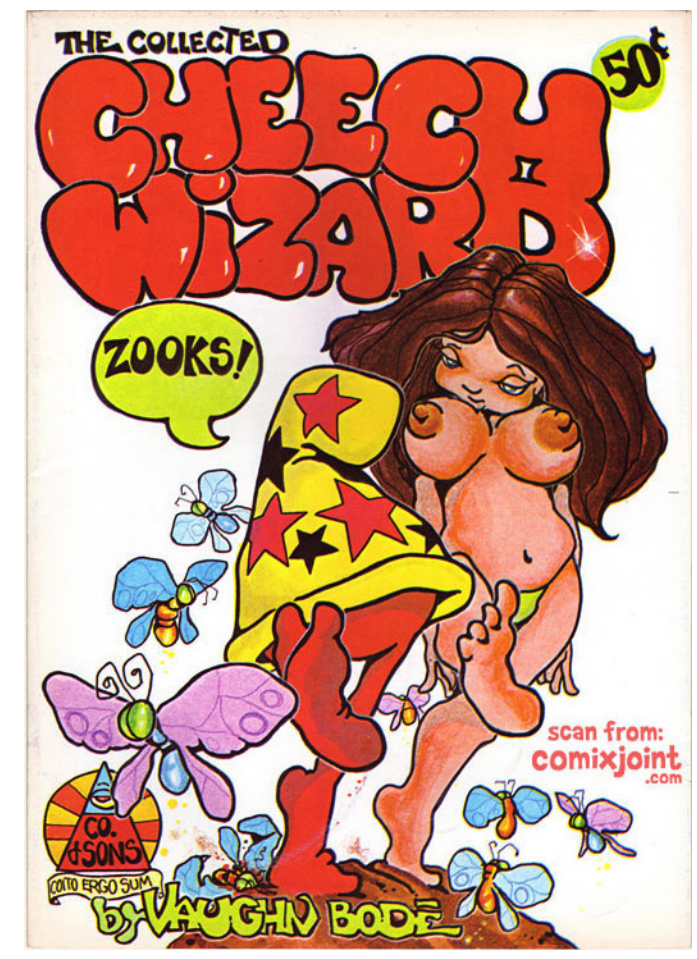

Fonte: http://comixjoint.com/cheechcollected-1st.html

Em 1970, o movimento perdeu força. Nessa mesma época, a Marvel vinha expandindo seus títulos, mas alguns de seus bons letreiristas estavam chegando ao fim da carreira. Embora a área fosse contemplada na premiação Shazam de quadrinhos, sendo Sam Rosen o primeiro letreirista ganhador, o cargo ainda era desvalorizado. Para um emprego em que se ganhava cerca de cinco dólares por página, os candidatos que se apresentavam não eram muito experientes, então o veterano Gaspar Saladino acabou sendo o responsável pelas capas e foi sobrecarregado de serviço até que os novatos aprimorassem suas habilidades. (Bradley, 2014)

Os pontos de exclamação ainda eram amplamente utilizados, porém, Cronin ${ }^{9}$ ressalta que o motivo não estava mais relacionado com o possível sumiço dos pontos finais durante a impressão. Eles eram usados para tornar os quadrinhos dinâmicos e contribuíam para dar tensão às cenas, afinal, os heróis estavam quase sempre exaltados.

9 CRONIN, B. Comic Book Legends Revealed \#245. Jan. 2010. Disponível em: < http://goodcomics.comicbookresources.com/2010/01/28/comic-book-legends-revealed-245/>. Acesso em: jul. 2014. 
De acordo com o letreirista Kurt Busiek ${ }^{10}$, as palavras em negrito também ganharam um novo propósito, além do estresse vocálico: elas ajudavam a quebrar as linhas. Um balão de várias linhas com letras maiúsculas facilmente é desfocado para uma mancha "cinza" quando visto a olho nu, mas palavras em negrito consertam isso, assim o olho não pula nem repete linhas, mesmo que o leitor não esteja consciente do porquê.

Jim Shooter, como editor-chefe da Marvel, não viu os dois recursos dessa forma. Ainda segundo Busiek, Shooter queria o mínimo de palavras em negrito, pontos de exclamação e traços duplos quanto fosse possível porque considerava-os juvenis. Outra exigência foi o posicionamento de todos os balões nos cantos superiores ou inferiores do quadro, independentemente de quão longe estivessem do locutor, porque o editor pensou que a padronização facilitaria a leitura. Contudo, suas restrições logo foram suspensas.

Assim como Jim Shooter, Eisner também questionava a maturidade do paradigma dos quadrinhos. O artista não queria que "Um contrato com Deus", obra depressiva e pesada, fosse distribuída por uma editora de quadrinhos. Em 1978, o livro foi disponibilizado nas livrarias sob a definição de graphic novel. Embora Eisner jamais tenha clamado que cunhou o termo, o conceito foi usado posteriormente por outros autores devido ao uso em "Um contrato". Seu trabalho tinha balões de fala provindas das HQs, assim como textos corridos de obras literárias. (Figura 43)

Figura 43. A contract with God and other tenement stories, por Will Eisner, 1978

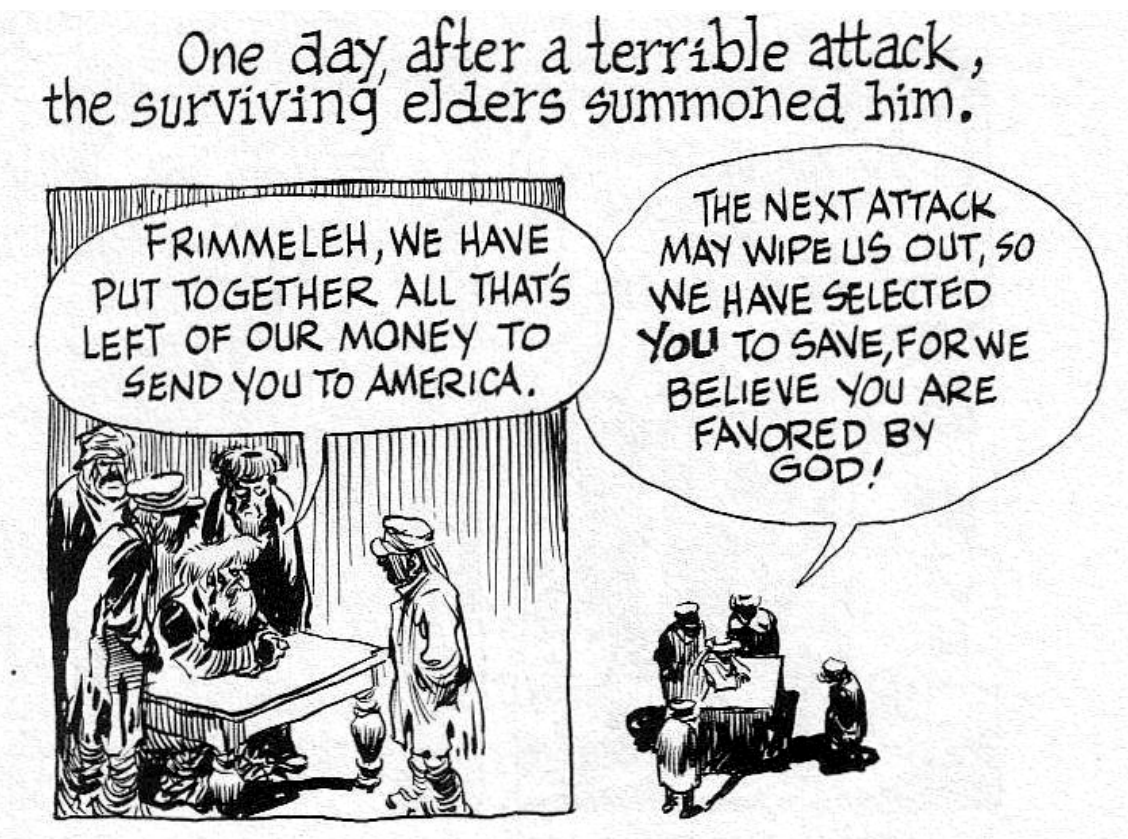

Fonte: EISNER, 2000, p. 20

10 Lettering Roundtable: the case regarding upper \& lower case lettering. Mesa redonda. Disponível em: <http://www.balloontales.com/articles/roundtable/>. Acesso em: jul. 2014. 
Uma abordagem similar havia sido feita por GIl Kane, que abandonou as bordas dos quadros e separou as passagens descritivas da imagem. Em 1971, Kane usou suas diferentes estratégias em Blackmark, com o uso de tipos em vez da convencional escrita à mão dos quadrinhos, imprimindo colunas de texto, recortando-as e colando-as. Infelizmente, como constatam Mazur e Danner (2014, p. 50-51), "o efeito de separar a palavra da imagem tende a minar o fluxo visual da narrativa" e a série foi cancelada.

Figura 44. Blackmark, ilustrado por Gil Kane e escrito por Archie Goodwin

\begin{abstract}
Another blow slammed into Marnie, sending her sprawing numbly. into the mud. Zeph's gnarled fingers fastened onto a stick not consumed in the campfire. His voice became the raging scream of a wild animal, drowning Marnie's tearful pleas.
\end{abstract}

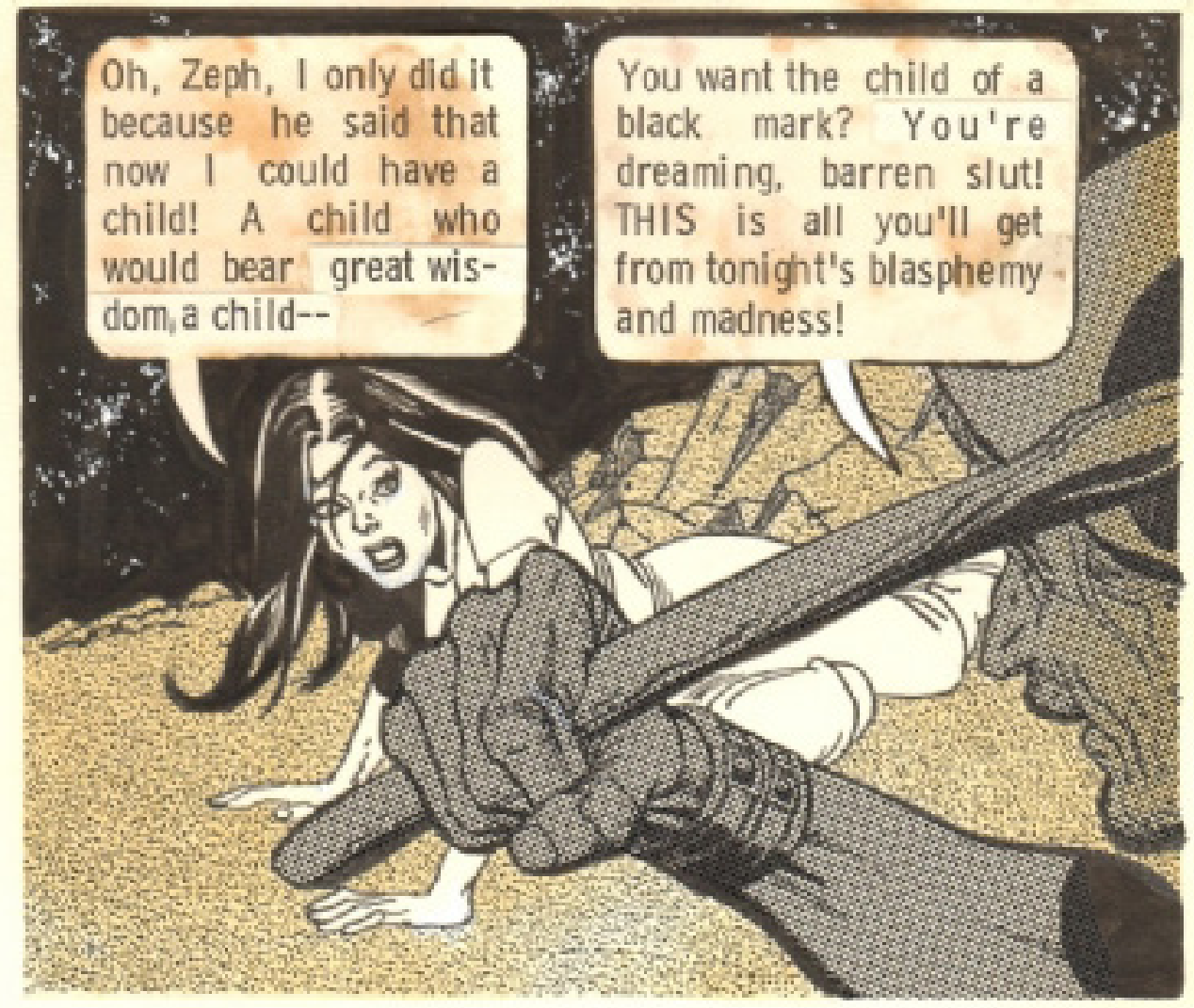

Fonte: http://www.comicartfans.com/GalleryPiece.asp?Piece=1087871\&GSub=152872 (escaneado por Ted Latner, 2005)

Outro exemplo que se aproximou da graphic novel foi First Kingdom, de Jack Katz (1974), onde o autor procurou recuperar uma tradição antiga em quadrinhos, o modo clássico de aventura de Tarzan e Príncipe Valente, de Hal Foster, usando blocos narrativos à parte da imagem, e não balões de fala. (Mazur; Danner, 2014, p. 60) 
A partir da década de 80, o lettering misto, isto é, que usa letras minúsculas e maiúsculas, foi progressivamente se tornando mais utilizado nos quadrinhos. Em 1986, Frank Miller escreveu Batman: Year One com as legendas nesse modelo e, em 1988, Todd Klein escreveu as falas de Morpheus com uma fonte mista em Sandman. "Eles não foram pioneiros no uso das letras minúsculas, mas ambos foram um enorme sucesso, e sucesso inspira imitação." (Bradley, 2014)

Graças ao uso de tipos, escrever em letras maiúsculas ou minúsculas não significava mais complexidade em relação ao processo. Contudo, como o uso da caixa alta se tornou convencional, até hoje se revela como a prática predominante na produção de HQs.

Por outro lado, houve tradições que passaram a ser gradualmente abandonadas. Editoras começaram a evitar recursos que não existem em filmes, como o uso de narrações em terceira pessoa, que diminuiu ao ponto de ser visto minimamente para identificar tempo e local. Os balões de pensamento também foram reduzidos, pois dificilmente os escritores conseguiam traduzir de forma realista o que o personagem estava pensando na cena. ${ }^{112}$

Outra mudança dos anos 80 foi a transformação no mercado de quadrinhos dos Estados Unidos. A cultura japonesa, que já vinha invadindo as terras ianques com o sucesso de Godzilla nos anos 50 e o desenho animado Astro Boy (Tetsuwan Atom, no original, criação de Tezuka), ia finalmente transpor as barreiras linguísticas que obstruíam a importação de mangás.

Em 1986, Toren Smith fundou o Estúdio Proteus, empresa pioneira de tradução de mangás na América. Ele adquiriu os direitos de várias obras para poder fotografá-las, traduzi-las e editá-las. O letreirista Tom Orzechowski desenvolveu técnicas para limpar o original e reletreirar os textos, assim, até os efeitos sonoros eram convertidos para a língua inglesa ${ }^{13}$. O mangá é tradicionalmente lido da direita para a esquerda, e a paginação segue nessa mesma ordem. Smith inverteu as páginas para que os americanos pudessem ler os quadrinhos asiáticos com mais facilidade. No início, os mangás não foram populares, mas sua venda serviu para disseminar o ritmo rápido da narrativa japonesa.

11 Lettering Roundtable: thinking about thought balloons, and other abandoned storytelling techniques. Mesa redonda. Disponível em: <http://www.balloontales.com/articles/thoughts/>. Acesso em: jul. 2014.

12 GRANT, S. Permanent damage. Comic Book Resources, fev. 2008. Disponível em: <http:// www.comicbookresources.com/? page=article\&id=15761>. Acesso em: abr. 2015.

$13 \mathrm{KHOURI}, \mathrm{A}$. Pioneering manga translator Toren Smith passes away at 52. Comics Alliance, mar. 2013. Disponível em: <http://comicsalliance.com/toren-smith-manga-translator-studio-proteus-death-obituary/?trackback=tsmclip>. Acesso em: set. 2014. 


\section{ERA DIGITAL}

Os mangás também influenciaram seu país de origem, visto que sua popularidade já superava os livros literários, principalmente entre a população mais jovem, chegando ao ponto de as estudantes desenvolverem um estilo de caligrafia baseado na escrita dos quadrinhos nipônicos, o chamado mangá-ji. As letras eram mais redondas e infantis do que as aprendidas na escola (Figura 45) e, por representarem um sinal de indisciplina, foram banidas por alguns diretores. Mesmo assim, estima-se que, em 1985, mais de cinco milhões de jovens haviam adotado essa escrita (Kinsella, 1995, p. 222). Durante os anos 80, as empresas captaram a nova onda e revistas, embalagens, publicidade e processadores de texto se adaptaram ao estilo.

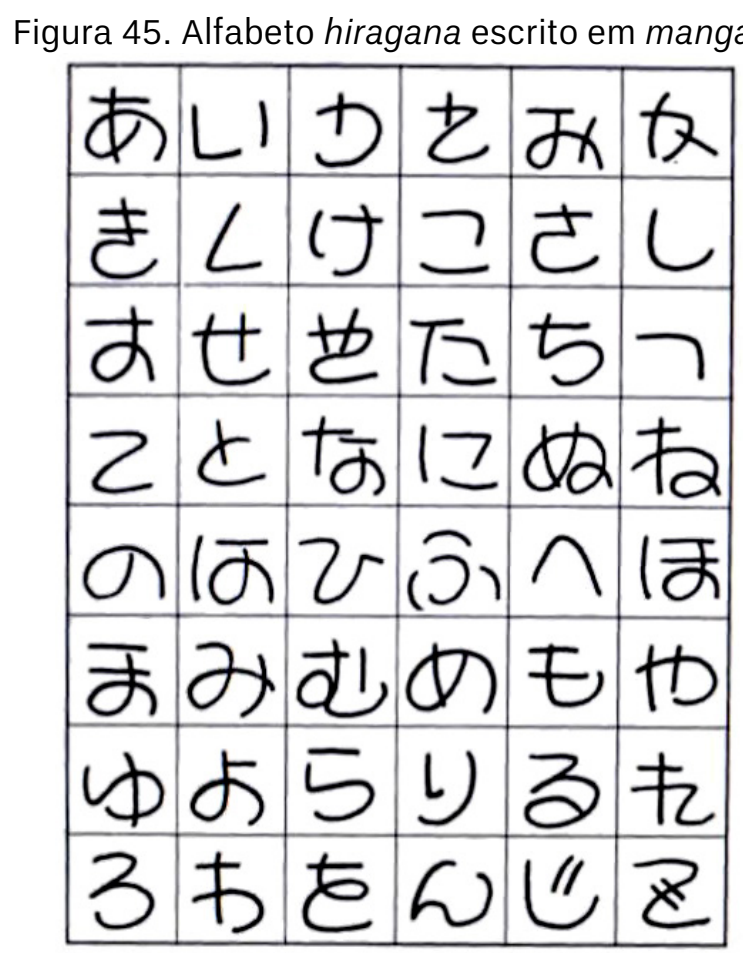

Fonte: KINSELLA, 1995, p.223

Aproximando do fim da década de 80, o uso de computadores já estava amplamente difundido. Segundo depoimento do letreirista Richard Starkings ${ }^{14}$, já se tinha notícia de uma graphic novel letreirada digitalmente por David Cody Weiss. Alguns outros livros experimentaram fontes de computador, tais como Michael Saenz em Shatter e Pepe Moreno com Batman: Digital Justice (Figura 46). Nos dois casos, o método foi justificado principalmente por remeter ao tema hi-tech das histórias, o que não deixava de representar uma façanha inovadora. (Bradley, 2014)

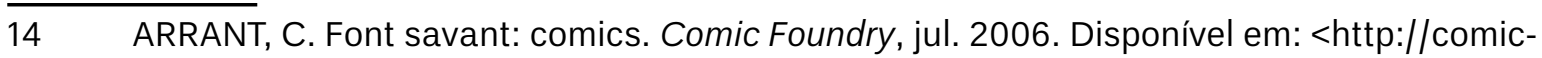
foundry.com/?p=1509>. Acesso em: set. 2014. 
Figura 46. Primeira página de Batman: Digital Justice, por Pepe Moreno, 1990

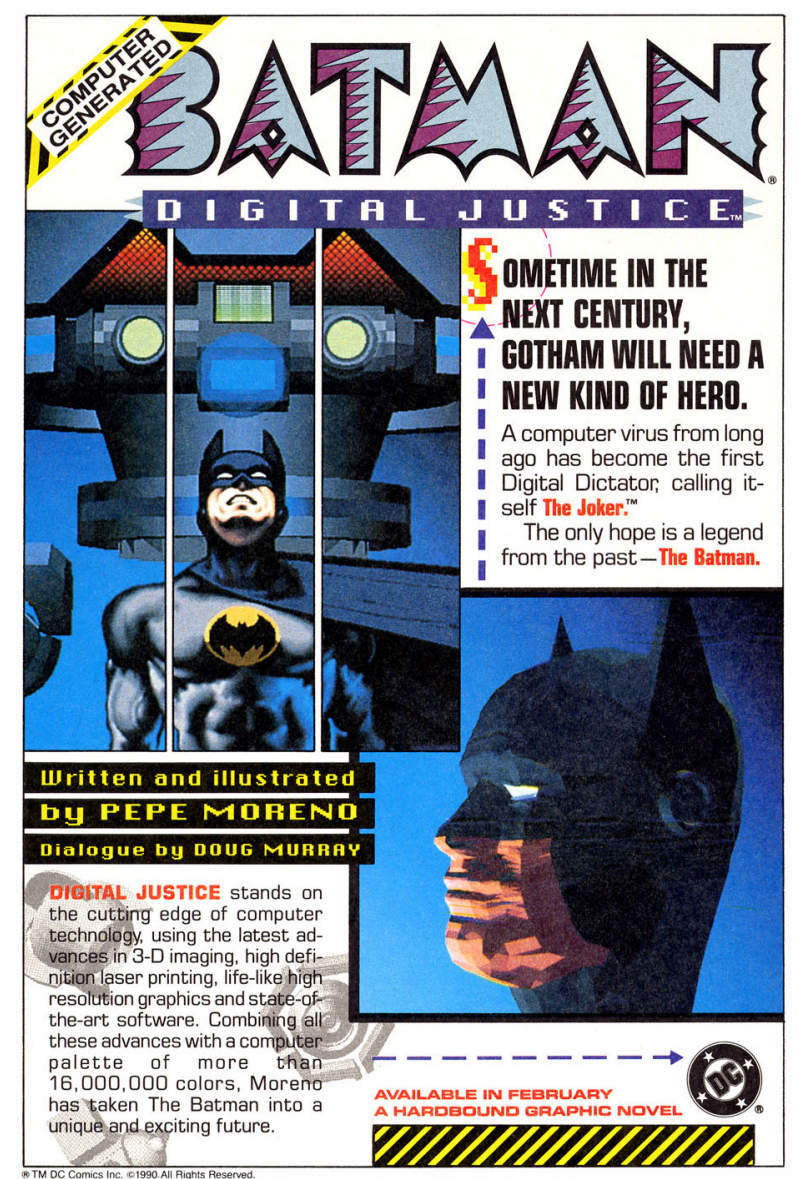

Fonte: http://estrelanerd.wordpress.com/2011/09/25/

Starkings comenta também que, no início dos anos 90, John Byrne criou fontes baseadas na caligrafia de letreiristas famosos, entre esses, Jack Morelli. Em acordo com Morelli, a fonte que imitava suas letras foi utilizada para Namor e outros trabaIhos da Marvel.

Um ano depois, Starkings se encontrou com Byrne e resolveu aderir ao time do lettering digital. Em seus primeiros trabalhos usando essa técnica, a editora ainda exigia que a etapa seguisse o procedimento padrão: os textos precisavam ser impressos para posteriormente serem colados sobre a arte. Devido a isso, houve um pouco de dificuldade para achar o tamanho de letra adequado, mas o problema logo foi superado e o público começou a se acostumar com o novo tipo de letreiramento.

Com o volume de serviço se acumulando, Starkings resolveu criar um estúdio exclusivamente de letreiramento em parceria com John Roshell. O site da companhia, Comicraft ${ }^{15}$, passou a ser não apenas um meio de solicitar serviços como funciona também de loja virtual para as fontes desenvolvidas.

Em 1992, quando a colorização passou a ser feita digitalmente, a indústria de quadrinhos resolveu tirar o máximo de proveito dos aspectos tecnológicos e os tex-

15 Disponível em: < http://www.comicraft.com/>. 
tos passaram a ser inseridos na arte escaneada. Petersen (2010, p. 228) considera a flexibilidade de ajustar a mover balões de fala como uma das maiores melhorias na produção de quadrinhos, pois o tamanho pode ser alterado para atender às necesidades da língua, reduzindo bastante o custo das obras traduzidas e expandindo a diversidade de títulos em diferentes idiomas.

Nesse ano, também foi fundada a editora Image. Em um esforço para publicar as melhores histórias em quadrinhos possíveis, a Image estava oferecendo melhores salários para letreiristas experientes. Isso gerou uma carência desses especialistas na DC e na Marvel, onde os editores acabaram recorrendo à Comicraft.

A partir daí, a preocupação com a qualidade do design textual nos quadrinhos foi crescendo, e mais premiações de quadrinhos abriam uma categoria para o letreiramento, com Don Thompson Awards nomeando letreiritas em 1992, Eisner Awards e Squiddy Awards em 1993, Eagle Awards em 2006, entre outras - Harvey Awards já tinha lançado essa categoria pela primeira vez em 1988.

Em 1994, Vincent Connare, designer da Microsoft, se deparou com um produto da empresa em que as falas do mascote eram escritas em Times New Roman ${ }^{16}$. Sentindo que isso era inapropriado, ele concebeu um novo tipo de letra com base no lettering de Dave Gibbons e John Constanza. A fonte foi chamada de Comic Sans e tem sido incluída como uma fonte padrão na maioria dos computadores há quase 20 anos.

Figura 47. Fonte Comics Sans, desenvolvida em 1994 por Vincent Connare

\section{ABCDEFGHIJKLMNOPQRSTUVWXYZ abcdefghijklmnopqrstuvwxyz 0123456789}

Fonte: da autora

Apesar de ter havido resistência contra o letreiramento digital, embate que perdura até hoje, mais e mais letreiristas decidiram condescender com o uso do computador para facilitar seu trabalho. Além dos contratados e dos autônomos, agora surgiam mais estúdios próprios para essa tarefa. Alguns que merecem destaque são a Blambot, fábrica tipográfica e companhia de letreiramento, fundada por Nate Piekos em 1999, e o estúdio Virtual Calligraphy, fundado por Chris Eliopoulo em 2003, que fez inúmeros trabalhos para a Marvel.

Os computadores agilizavam o letreiramento, mas os benefícios dos softwares utilizados não se restringiam apenas aos profissionais que trabalhavam na área. Com a possibilidade de escanear revistas, editá-las e distribui-las sem grandes complicações, grupos de fãs começaram a se juntar para traduzir quadrinhos de outros países, formando as chamadas equipes de scanlation. Para simplificar o pro-

16 CONNARE, V. Why Comic Sans?. Vincent Connare: photography and typography, 2003.

Disponível em: <http://www.connare.com/whycomic.htm>. Acesso em: jul. 2014. 
cesso, os fãs não invertiam as imagens dos mangás nem traduziam as onomatopeias, deixando as páginas mais similares ao trabalho autêntico. Essa atividade clandestina corroborou para que os leitores se habituassem à orientação de leitura japonesa, bem como aos efeitos sonoros originais.

Em 2002, a editora TokyoPop atendeu ao pedido do autor Akira Toriyama de não inverter as páginas e parar de substituir as onomatopeias. Ao adotar essa pragmática, mais mangakás se sentiram propensos a licenciar suas obras para editoras ianques. Os mangás pegaram carona na febre que estavam sendo os jogos e animações japonesas e tiveram suas vendas disparadas, com a Shônen Jump atingindo o dobro de exemplares vendidos em comparação a Spider-man. (Van Lente; Dunlavey, 2012; p. 197)

A Eagle One Media, em 2001, publicou uma série de quadrinhos digitais em CD-ROM que empregava motion graphics, diálogos falados, música e efeitos sonoros para criar uma multimídia que se aproxima da experiência de ver um filme de animação. (Petersen, 2010, p. 228) No entanto, o resultado foi um produto carente da movimentação natural dos desenhos animados e desprovido da participação do leitor como ocorre nos gibis, o que fez com que o público cativado pela novidade dificilmente a considere como uma substituta às histórias em quadrinhos.

Outro advento digital consiste nos muitos geradores de quadrinhos que oferecem até àqueles com mínima habilidade de desenho a oportunidade de montar uma história em quadrinhos. Programas como o Bitstrips, Comic Life, Comic Book Creator e uma série de outras aplicações online tornaram mais fácil a geração de quadrinhos com qualquer forma de imagens digitais e fornecem filtros que tornam possível "quadrinizar" fotografias para que elas fiquem parecias com uma pintura de Lichtenstein, com cores berrantes e pontos Benday.

Figura 48. Tirinha produzida pelo aplicativo Bitstrips, pela usuária Nolimity

NEW LIFE IN BISTRIPS.

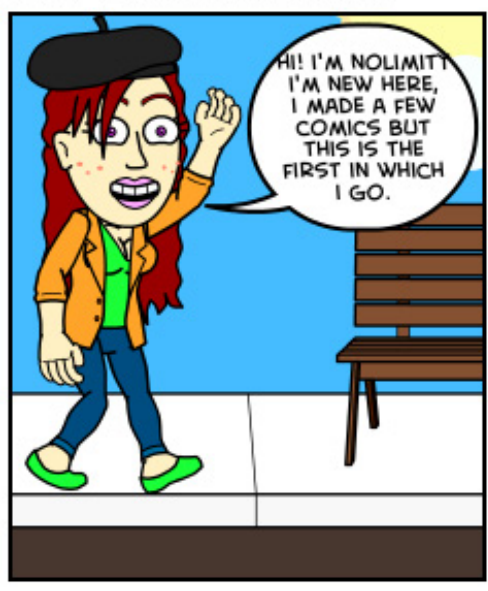

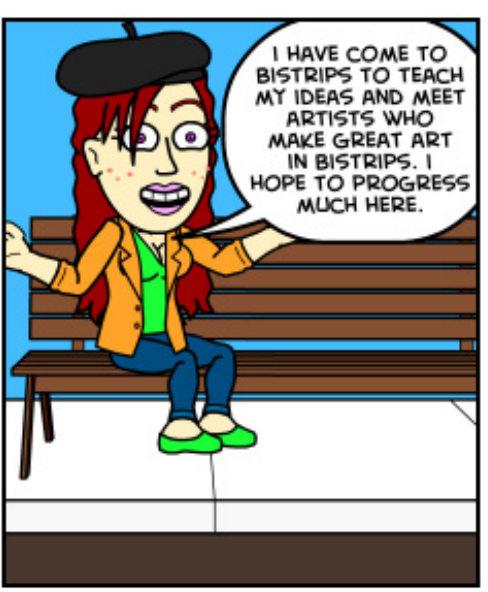

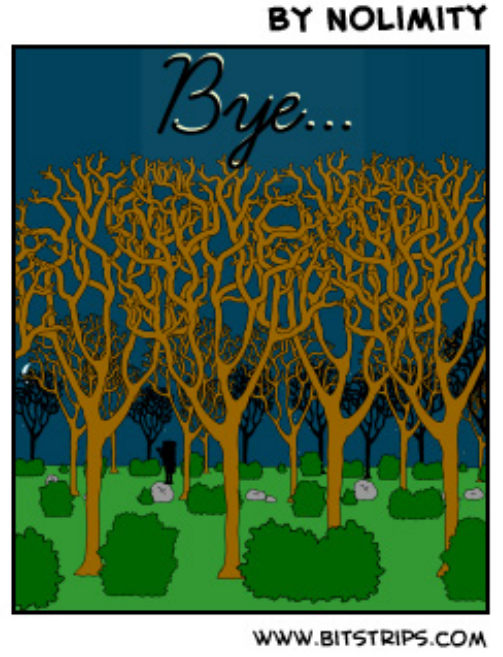

Fonte: http://www.bitstrips.com 
Estes serviços proporcionam competição criativa entre os usuários que postam os seus trabalhos online, os quais disputam classificação entre os mais populares. Embora leigos e iniciantes apreciem o escopo de possibilidades artísticas, o resultado é muito limitado às ferramentas disponíveis.

Mesmo com a proliferação de ferramentas digitais, as formas tradicionais não foram completamente abandonadas. Muitos dos profissionais que usam letreiração digital sabem usar um Ames Guide, e alguns trabalhos ainda são feitos no estilo clássico. A editora Maurício de Sousa conserva a tradição do letreiramento manual em seus gibis, que são publicados há mais de 50 anos. Segundo o editor-chefe Sidney Gusman, essa prática preserva o lado artesanal do processo. ${ }^{17}$ Uma das letreiristas do estúdio, Elisa Lacerda (apud Fernandes, 2006, p. 89), afirma que "fazer as letras à mão facilita o posicionamento do texto dentro dos balões, já que existe uma medida prévia de alinhamento, entrelinhamento e entre o texto e as bordas".

Em 2010, a DC Comics fez uma parceria com a Marvel para apresentar seu próprio aplicativo e muitas das principais editoras de quadrinhos dos EUA (Dark Horse, Top Cow, IDW e Archie) tinham entrado no mercado digital ao lado de uma série de outras editoras que fornecem quadrinhos estrangeiros. Com o sucesso das tablets e dos novos suportes tecnológicos, a indústria de quadrinhos parece ter um veículo para estabelecer um mercado digital substancial.

Outro meio virtual que se encontra em próspero crescimento são as redes sociais. Graças a isso, a internet é um espaço propício para a divulgação de trabalhos independentes e para os quadrinistas se auto-promoverem. Seguindo esse caminho, surgiram as web comics, histórias em quadrinhos que veiculam especialmente no ciberespaço. São nas tiras produzidas digitalmente o local mais comum para encontrar letras escritas pelo próprio autor (Figura 49).

Figura 49. Clube do Pança, por Caetano Cury
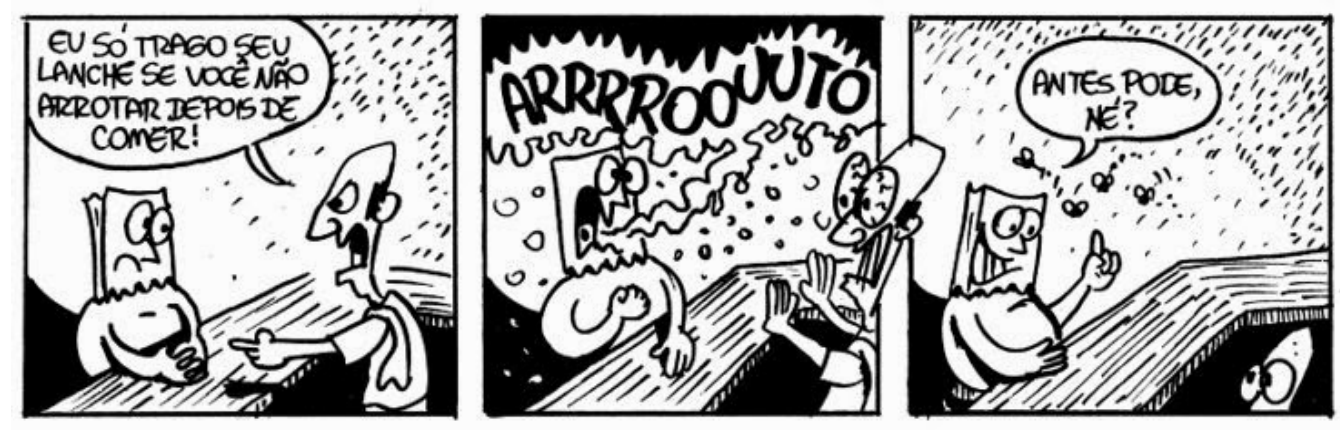

Fonte: http://www.teoeominimundo.com.br/

Dessa forma, percebe-se que o avanço tecnológico que antes era repudiado como uma ameaça à qualidade do letreiramento se tornou uma grande vantagem para os letreiristas que sabem aproveitá-lo. Além disso, a internet ampliou o contato

17 TURMA DA MÔNICA. Processo de produção de HQ na Mauricio de Sousa Produções. Disponível em: <https://www.youtube.com/watch?v=yYuYqWcoF5s>. Acesso em: out. 2014. 
com as HQs em um sentido que torna os leitores mais sensíveis às minúcias de cada etapa de produção. O trabalho gráfico textual é debatido em fóruns de discussão e alguns tópicos já se voltam para saber quem é o letreirista favorito de cada membro. Se antes esses profissionais não eram tão conhecidos, agora eles são procurados em seus websites, onde dão dicas de lettering.

É encorajador ver que ao longo dos séculos narrativas gráficas continuaram a evoluir para uma linguagem de palavra-imagem que é bem adequada para expressar idéias complexas através de uma variedade de impressões em papel e de plataformas digitais. Com a exposição cada vez maior, o vocabulário de possíveis idéias só cresce em complexidade, ao passo que os leitores se tornam mais abertos ao desenvolvimento de novas convenções. 


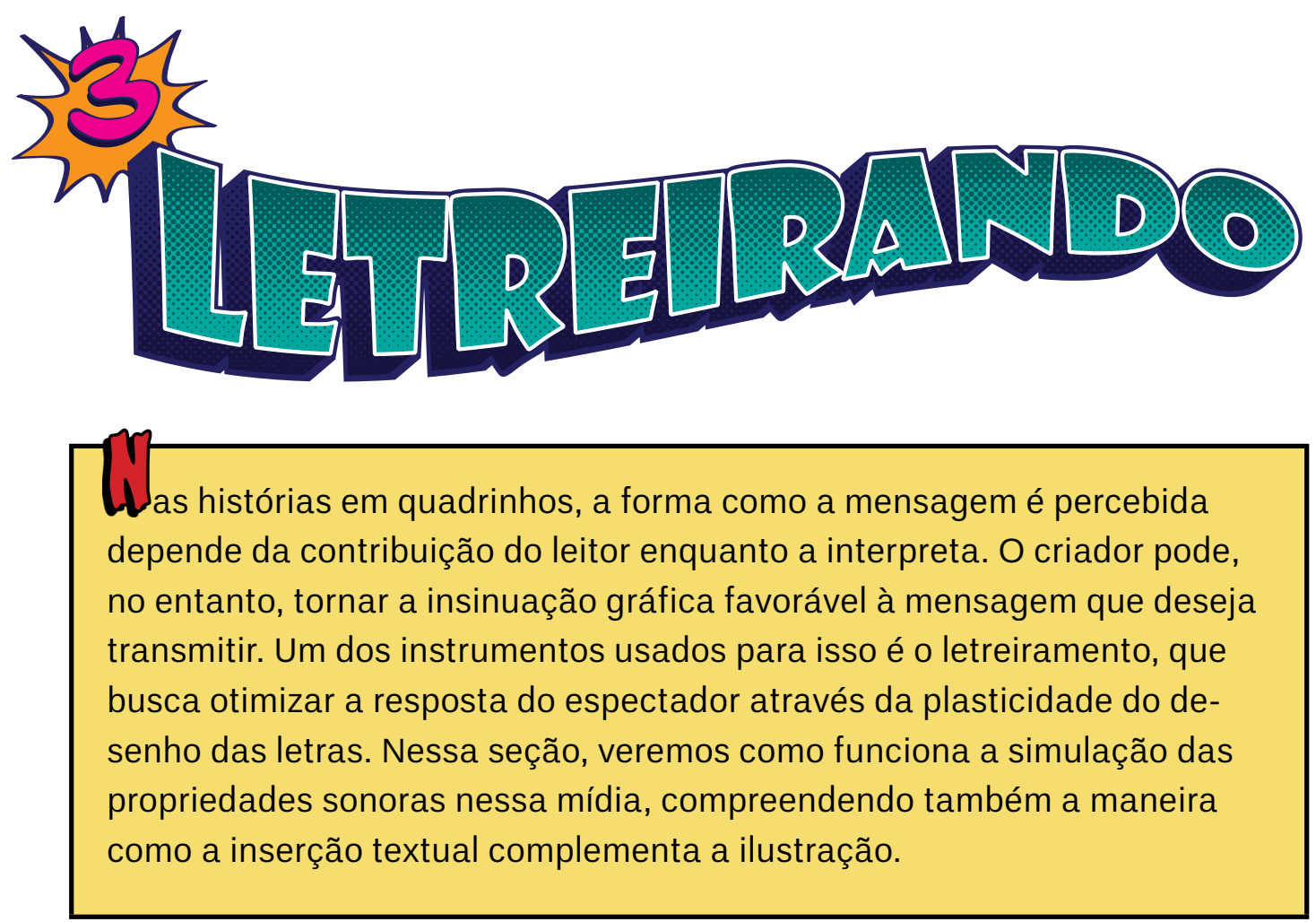

Letreirar, como o próprio termo indica, constitui todo procedimento relativo ao emprego de letras nas histórias em quadrinhos. Portanto, falas, narrações, títulos, créditos e quaisquer tipos de texto são os objetos de trabalho desse segmento.

Nos quadrinhos, a transmissão da história depende do proveito tirado tanto do mundo das palavras quanto do mundo das imagens, de modo que os dois interajam entre si. As palavras escritas, então, devem ser colocadas em relação harmônica com as ilustrações, buscando maximizar o potencial para contar histórias que esses elementos alcançam mutualmente. O ideal está longe de propor uma competição entre as duas simbologias; pelo contrário, deve-se combiná-las de forma que uma favoreça a manifestação da outra.

Na produção, a ilustração antecede a parte escrita, mas desde os primeiros rascunhos, o volume de texto é levado em consideração e é previsto o espaço adequado para sua inserção. Este é ajustado nos locais predeterminados, com o cuidado de não cobrir elementos importantes do desenho caso a área seja insuficiente.

Assim como em qualquer trabalho de diagramação, a qualidade por que o letreiramento deve prezar acima de tudo é a legibilidade. O tamanho da letra e os espaçamentos apropriados são preocupações a serem tomadas para não comprometer a compreensão do que está escrito.

Outra finalidade dessa etapa é guiar o olhar do leitor pela página e definir a cadência narrativa, por meio do posicionamento dos balões e da quebra de texto.

Além disso, é possível explorar os estilos gráficos para tornar os textos mais expressivos e mais condizentes com os aspectos que o autor deseja passar, como será visto nos subcapítulos seguintes. 


\section{TIPOS DE TEXTO}

Antes de prosseguir com as propriedades do letreiramento, é fundamental entender as diferentes categorias em que se encaixam os textos nas histórias em quadrinhos. Cada tipo tem suas particularidades que exigem tratamentos específicos no que tange à construção gráfica.

A categoria que é normalmente vista primeiro nas HQs é a de títulos. É um texto curto, de função distintiva, que serve para identificar a obra e abrir a história. O criador da empresa Blambot explica que cada título deve capturar a essência da trama e dos personagens envolvidos, além de responder ao estilo do livro para o qual o design se destina ${ }^{18}$.

Embora seja possível contar histórias unicamente por meio de imagens, Comparato $(2009$, p. 173) defende a necessidade do diálogo para a caracterização dos personagens e para o desenvolvimento do enredo. Tal importância é averiguada também nas histórias em quadrinhos, onde a ideia de comunicação é geralmente transmitida por meio dos chamados textos de diálogo. Estes se subdividem em diálogo externo, o qual representa a fala articulada, e em monólogo interno, definido pelo pensamento.

Quando a imagem é insuficiente para transmitir a mensagem e os personagens são inapropriados para proferi-la, são usados os letreiros (caption, em inglês). Piekos ${ }^{19}$ os classifica em cinco tipos: local, temporal, falado, editorial e de monólogo interno. Os dois primeiros são descritivos, com a função de situar o leitor na data e/ ou no lugar onde se passa a trama. O letreiro falado, por sua vez, apresenta a fala verbalizada de um personagem que não está em cena. Para evitar confusão com os outros tipos de letreiro, o conteúdo falado deve vir entre aspas. O tipo editorial tem como conteúdo as notas do escritor e do editor. Funciona como as notas de rodapé de um texto literário: seu texto geralmente vem precedido de asterisco, podendo ser ligado a alguma fala no mesmo quadro. O monólogo interno reflete uma narrativa em primeira pessoa e expressa os pensamentos, opiniões e sentimentos do personagem que narra.

Semelhantes aos letreiros, os anúncios também exercem função de narração em terceira pessoa. Estes possuem o propósito específico de publicidade, de levar curiosidade e ansiedade aos leitores. São os comentários da capa que enaltecem o protagonista ou revelam parte da aventura, as chamadas nas aberturas dos capítulos, os "Continua", os prenúncios do que vem a seguir e algumas propagandas.

Os créditos revelam os nomes daqueles que conceberam a obra, explicitando o papel de cada um na produção. O escritor e o ilustrador aparecem na capa, enquanto os demais colaboradores são contemplados na primeira página da história.

18 PIEKOS, N. Title Deeds. Blambot, 2013. Disponível em: <http://www.balloontales.com/articles/tutorial/part3.html>. Acesso em: jul. 2014.

19 Comic book grammar \& tradition. Blambot, 2013. Disponível em: <http://www.

blambot.com/grammar.shtml>. Acesso em: jul. 2014. 
Em alguns casos, quando não é cabível escrever os créditos na ilustração ou em reforço a estes, os responsáveis são expressos na folha de rosto da publicação.

Paratextos linguísticos são textos que fazem parte da ilustração, como o caso de palavras em um livro desenhado, nomes em placas, cartazes, enfim, componentes visíveis aos personagens e que requerem alguma inscrição.

A numeração da página aparece discreta e sem interferir na arte, frequentemente localizada na área mais externa do papel. Para reduzir a quantidade de informações visuais, há obras que incluem o número em apenas algumas páginas. Há situações em que nenhuma é numerada, apenas de haver sumário.

Por fim, existem os efeitos especiais de som, que surgem para oferecer expressividade sonora nos quadrinhos. Esse tipo de texto se caracteriza pela junção de fonemas que simulam o ruído desejado. Segundo Luyten (2001-2002, p. 04), o efeito das onomatopeias proporciona "uma complementação eficiente à imagem e adicionou aos quadrinhos uma nova dimensão estética." Explorações criativas podem ser feitas com fontes, tamanhos, cores, sombras, colocação, orientação espacial e curvaturas para tornar o efeito sonoro mais evocativo e adaptado à arte.

\section{SUPORTES DE TEXTO}

Para o texto não ficar oculto no meio do desenho, recorre-se a suportes que oferecem contraste com a imagem de fundo. Como foi apresentado no capítulo anterior, as primeiras concepções de suporte foram pergaminhos, que com o passar do tempo, foram abandonando o material concreto e seguiram para formatos incorpóreos. Após muitas experimentações, rejeições e admissões arbitrárias, alguns deles mostraram sua adequação e se tornaram elementos fundamentais dos quadrinhos. (Cirne, 1977, p. 19)

\subsubsection{O balão}

O balão, também chamado de bolha ou locugrama, é o suporte mais conhecido para dar visibilidade ao som falado. Considerado por Eisner (2010, p. 24) como um recurso extremo, o balão é representado por um recipiente arredondado, com um apontador (chamado de rabicho) indicando o locutor. O autor indica que o desenho se aproxima do vapor de ar quente exalado ao se falar em dias frios (idem, p. 25). Embora seja geralmente oval, o formato não é obrigatoriamente elíptico: alguns são quadrados ou retangulares, enquanto alguns mostram apenas a seta indicadora. (Figura 50) 
Figura 50. Tirinha com balões tradicionais no primeiro quadro e o segundo apenas com o rabicho
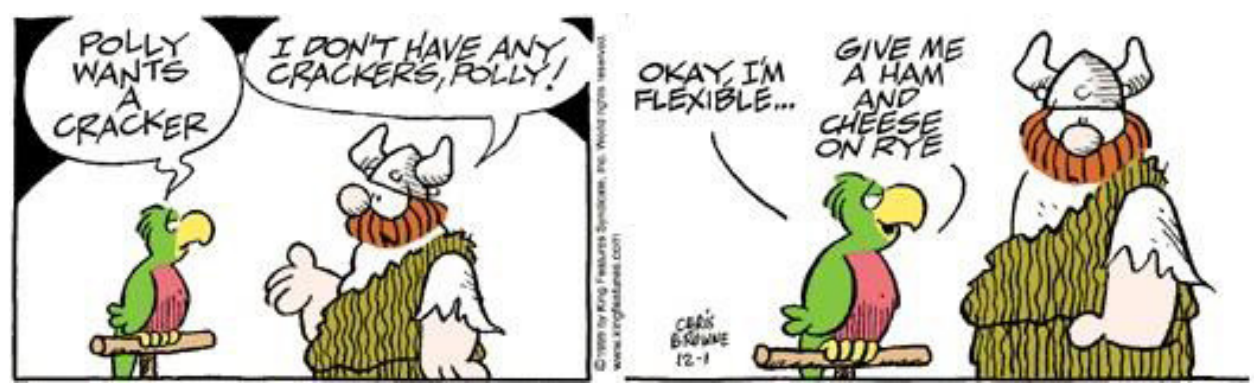

Fonte: BRowne, 1999, $01 \mathrm{dez}$.

As incumbências do balão ultrapassam a dos textos pronunciados oralmente, ganhando novos formatos para revelar o que o personagem está pensando. Enquanto o balão com o rabicho definido é utilizado principalmente para denotar diálogo externo, para o monólogo interno, o balão assume formas mais impalpáveis, assemelhando-se a uma nuvem. O rabicho acompanha essa mudança e vira uma sucessão de bolhas que vão diminuindo gradativamente até a cabeça do personagem pensante. Alguns personagens, principalmente animais como o gato Garfield e o cão Snoopy, expressam-se sobretudo através de balões de pensamento, dada sua incapacidade de fala.

Alguns autores preferem manter a forma elíptica no lugar da nuvem, com o rabicho em bolhas. Artistas japoneses aderem a esse formato menos bolhudo, mas frequentemente usam um balão diferente para mostrar o pensamento: sem rabicho, o balão é arredondado e sua borda é formada por várias agulhas divergentes emparelhadas. (Figura 51) O resultado é semelhante ao efeito de eco na mídia televisiva.

Figura 51. Balões de pensamento em mangá

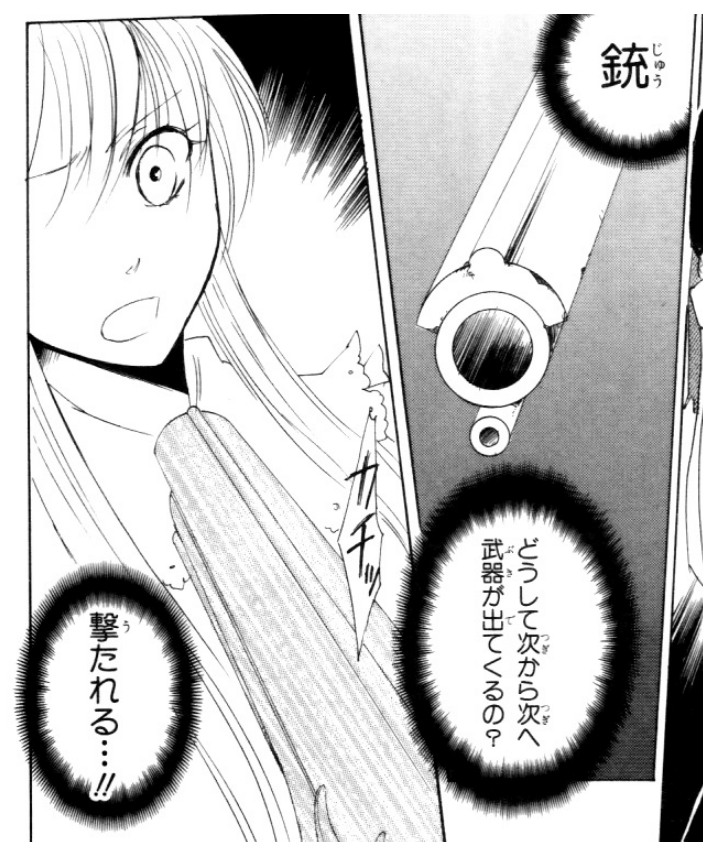

Fonte: QUINROSE; FUJIMARU, 2011, p. 38 
No caso de mais de um emitente, ou seja, a mesma fala ser dita por mais de um personagem, o que muda é apenas o número de rabichos, que não necessariamente condizem com o número de falantes. Em oposição, os quadrinhos japoneses tendem a puxar o rabicho para dentro do balão ou manter apenas a elipse, sem indicador de um locutor em específico, fazendo com que os leitores identifiquem a fonte da fala pelo contexto. O mesmo balão sem rabicho ocorre quando o personagem falante não está visível aos leitores, já os quadrinistas ocidentais preferem puxar o rabicho para fora do quadro. (Figura 52)

Figura 52. Fala com locutor fora de cena

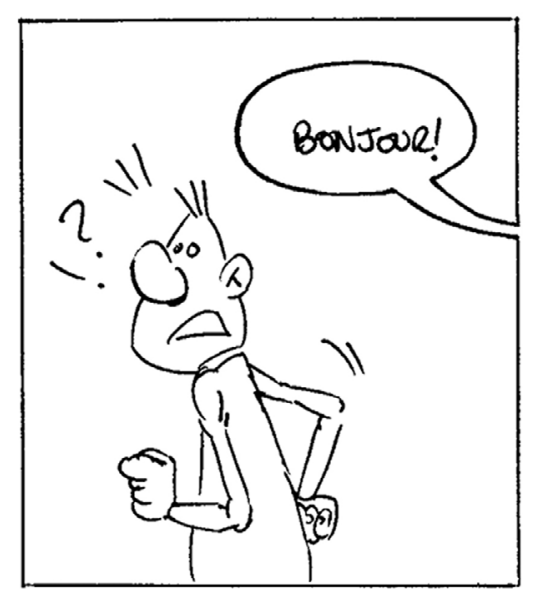

Fonte: LAINÉ; DELZANT, 2010, p. 35.

À medida que o uso dos balões foi crescendo, sua função transcendeu a de delimitador de fala e seu contorno (chamado também de perigrama) passou a atribuir características à maneira de expressão do locutor. (Eisner, 2010, p. 24) Embora o balão de fala em sua forma mais básica (arredondado, branco e com contorno preto) seja a mais conhecida, existem variações tão empregadas que se tornaram habituais aos leitores de quadrinhos.

Benayoun (1968) categoriza 72 tipos frequentemente encontrados, mostrando que os quadrinistas dispõem de uma ampla gama de possibilidades para o uso do balão. Entre as finalidades que este pode desempenhar, o suporte pode demonstrar tonalidade e volume de voz. Balões dentados são chamativos e evocam gritos ou brados. Os sussurros, por sua vez, mesclam-se com o som do ambiente e, por isso, o balão muitas vezes é desenhado com a borda tracejada. Quando utilizado com o rabicho pontiagudo, o balão em nuvem podem indicar fala com entusiasmo ou com suavidade de voz. 
Figura 53. Uso de balão de susssuros, balão de grito e balão de pensamento
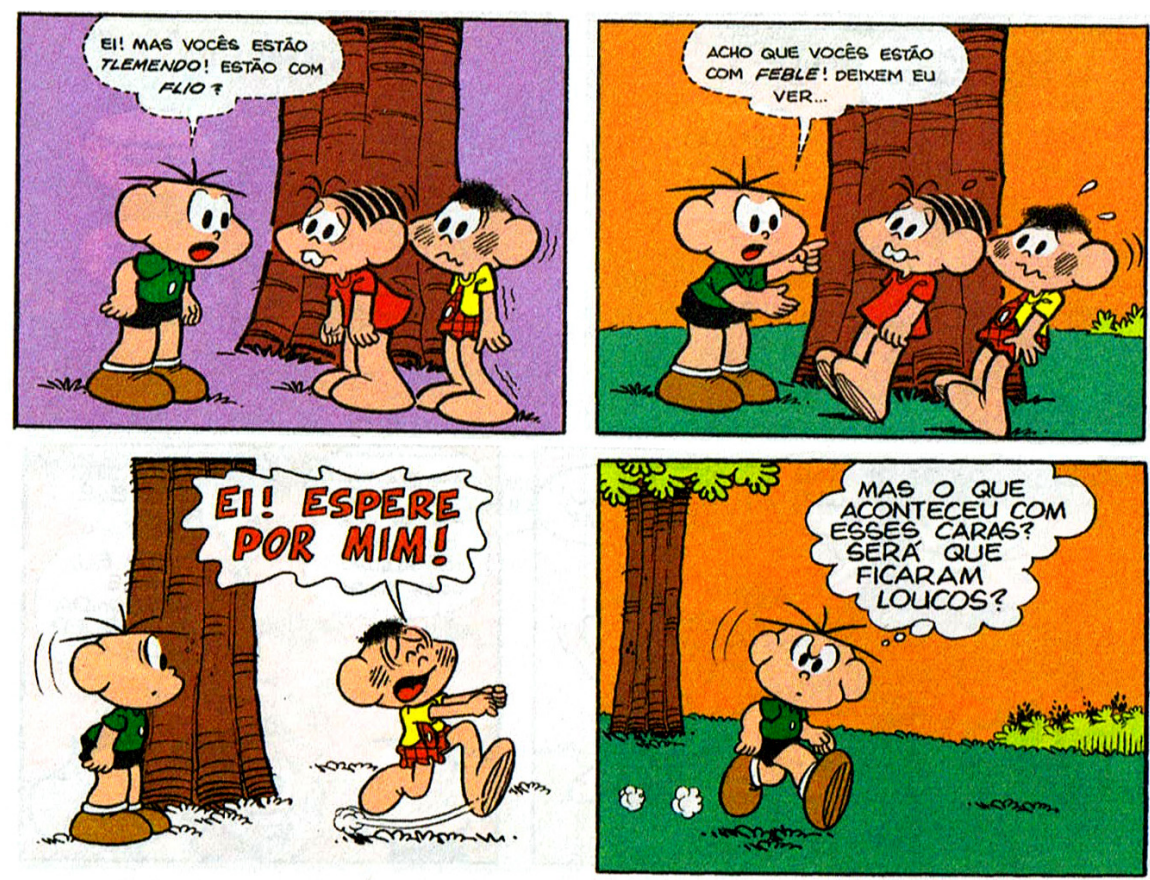

Fonte: SousA, 2013 , v. 33 , p. $62-63$

Existem mais maneiras como o balão é desenhado que atribuem mais expressividade à cena. Para enfatizar a frieza, seja no sentido climático, seja no sentido de desprezo, é comum encontrar balões cuja base inferior se desfaz em sincelos. (Figura 54 e Figura 55) Nos quadrinhos modernos, algumas vezes, as cores são usadas para combinar com o sentimento do personagem, como verde de inveja ou vermelho de raiva.

Figura 54. Desenho do balão salientando a frieza do personagem

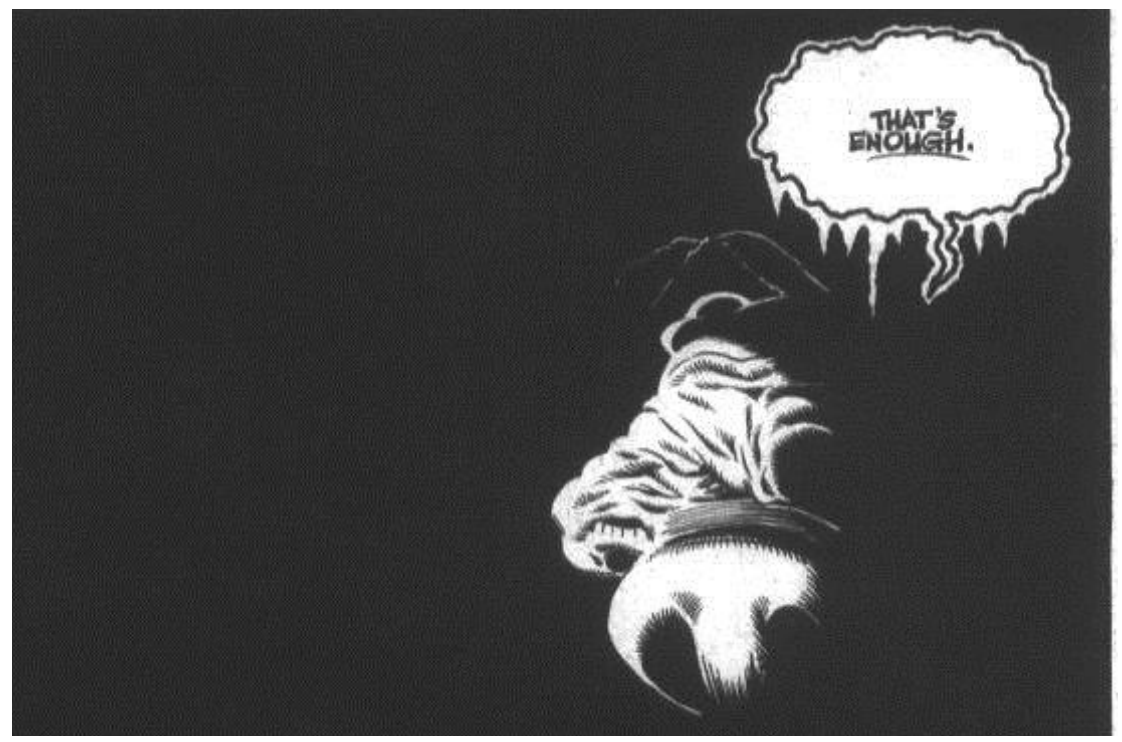

Fonte: SIM, 2004, cap. 299, p. 12. 
Figura 55. Balão remetendo ao clima frio
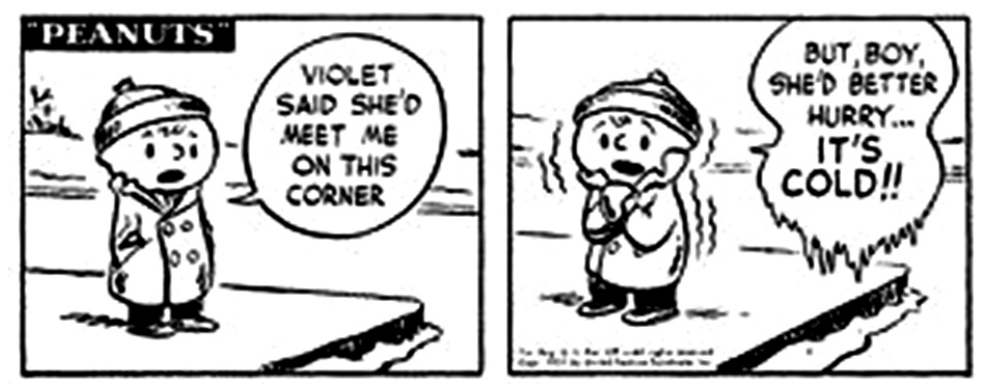

Fonte: Peanuts, por Charles Schulz, 1951

Como visto nas imagens anteriores, a decoração do suporte insinua a maneira como a fala deve ser lida. Notas musicais espalhadas pelo balão pedem uma interpretação melódica, enquanto bolhas indicam embriaguez e corações realçam a expressão romântica do personagem.

$\mathrm{Na}$ Figura 56, Goscinny e Uderzo tiram proveito dessa potencialidade para inserir humor na aventura de Asterix. O contorno florido do balão impregna a fala de meiguice, a qual é subitamente cortada por um berro exageradamente alto - o volume é intensificado pelo tamanho das letras e pelo balão explosivo.

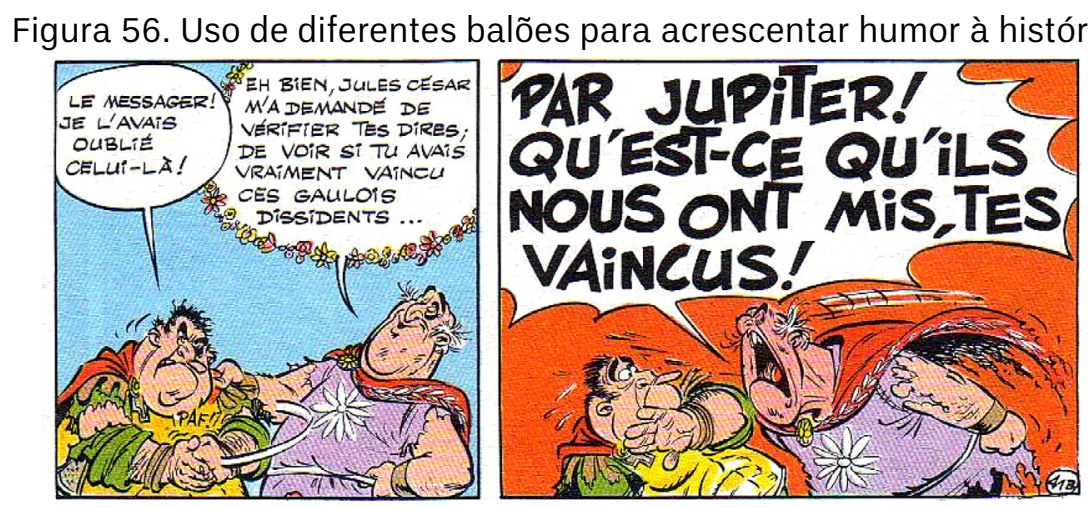

Fonte: GosCINNY; UDERZO, 1972, p. 42

Existem dicas generalizadas para reforçar a excentricidade de criaturas fictícias. Para realçar o caráter sombrio dos monstros, artistas recorrem a balões com sangue ou gosma escorrendo. Aos robôs e máquinas, são sugeridos balões poligonais que condizem com a exatidão de seu processamento e com a regularidade de seu tom de voz. Outra opção é usar o chamado balão de transmissão, caracterizado por seu formato irregular e rabicho de relâmpago, o qual também é utilizado para representar comunicações através de aparelhos eletrônicos, como rádio e televisão.

Ademais, os balões não apenas são customizados para espécies distintas de seres, como possuem também potencial para dar vozes particulares a determinados personagens. Como o formato é normalmente padronizado para toda a série, a aparição de um balão estilizado que é usado unicamente por um ou poucos personagens indica que a voz possui alguma singularidade notável: 
Figura 57. O personagem Sonho ganha voz diferenciada através do balão de fala

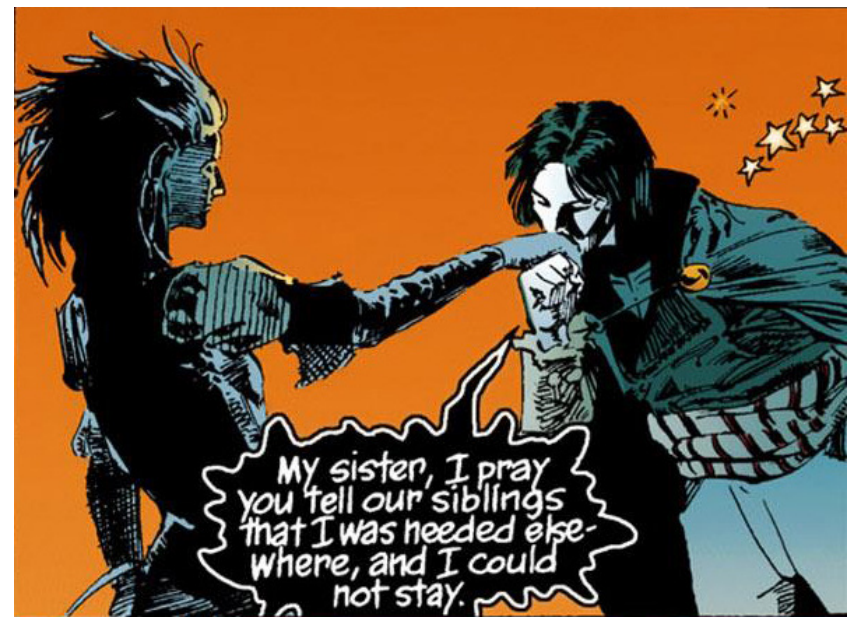

Fonte: GAIMAN, 1990-1991, p. 24 (letras por Todd Klein)

É possível distinguir a voz do protagonista de Sandman, representado na Figura 57, por fatores visuais: enquanto a maioria destes apresentam o texto todo em caixa alta, a fala de Sonho contém também letras minúsculas; seu balão é negro, envolto por um contorno branco e serpenteante, ao contrário dos balões redondos e brancos dos personagens em geral. Além de as bordas amorfas tornarem a fala etérea, as distinções mencionadas prescrevem uma voz sombria, proeminente e sóbria, a qual condiz com sua personalidade.

A diferenciação através do suporte de fala pode acontecer também com a finalidade de distinguir um emissor de outro, quando o volume textual é grande ou quando um dos falantes não está presente na cena. Na Figura 58, dois personagens conversam telepaticamente e a troca de informações é densa. Com o uso de um balão com bordas coloridas apenas para o professor Stick, a associação de pensamentos a seus respectivos emissores é imediata.

Figura 58. Uso de balão diferenciado para distinguir emissores

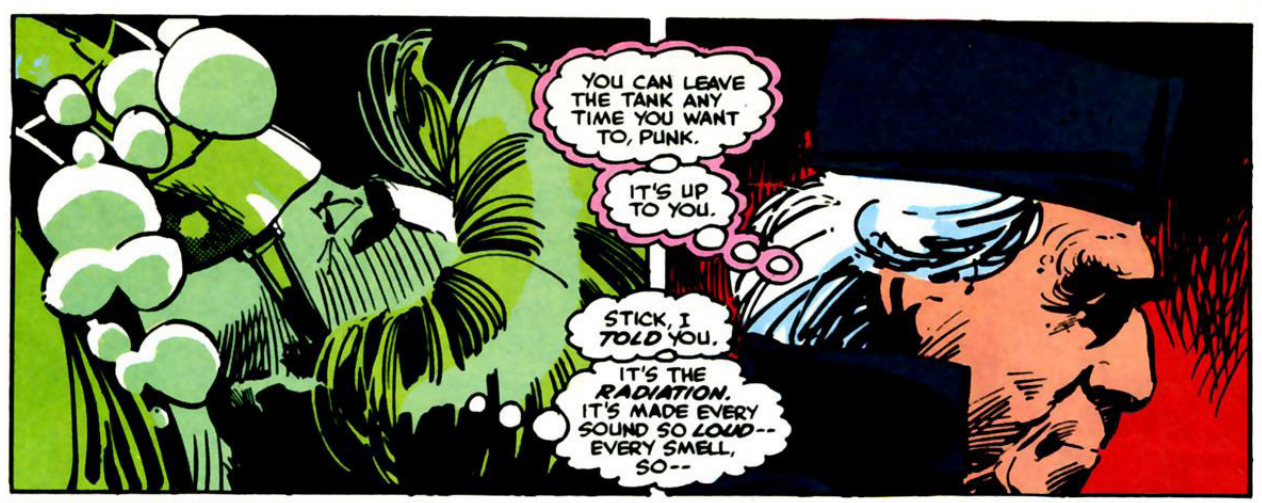

Fonte: MILLER; JANSON, 1996, p. 65 (letras por Comicraft) 


\subsubsection{Metalinguagem dos balões}

Após décadas de uso constante, os balões se consolidaram como um meio representativo da fala amplamente reconhecido. De fato, trata-se de um elemento tão intrínseco aos quadrinhos que é um símbolo muito usado na metalinguagem, sistema em que o conteúdo é a própria linguagem. Dentre os casos de metaquadrinhos apontados por Valente (apud Sousa, 2006, p. 22), o mais comum é quando o meio faz autoparódia, ou seja, a história satiriza as regras e os aspectos inverossímeis da própria mídia.

Por hábito, compreendemos o balão como um objeto invisível dentro da história. Quadrinistas aproveitam essa convenção para provocar o inesperado: os balões se materializam ou apresentam propriedades físicas como se fossem sólidos.

Figura 59. Balão de fala tratado como balão de látex, por Brian McLachlan, 2012
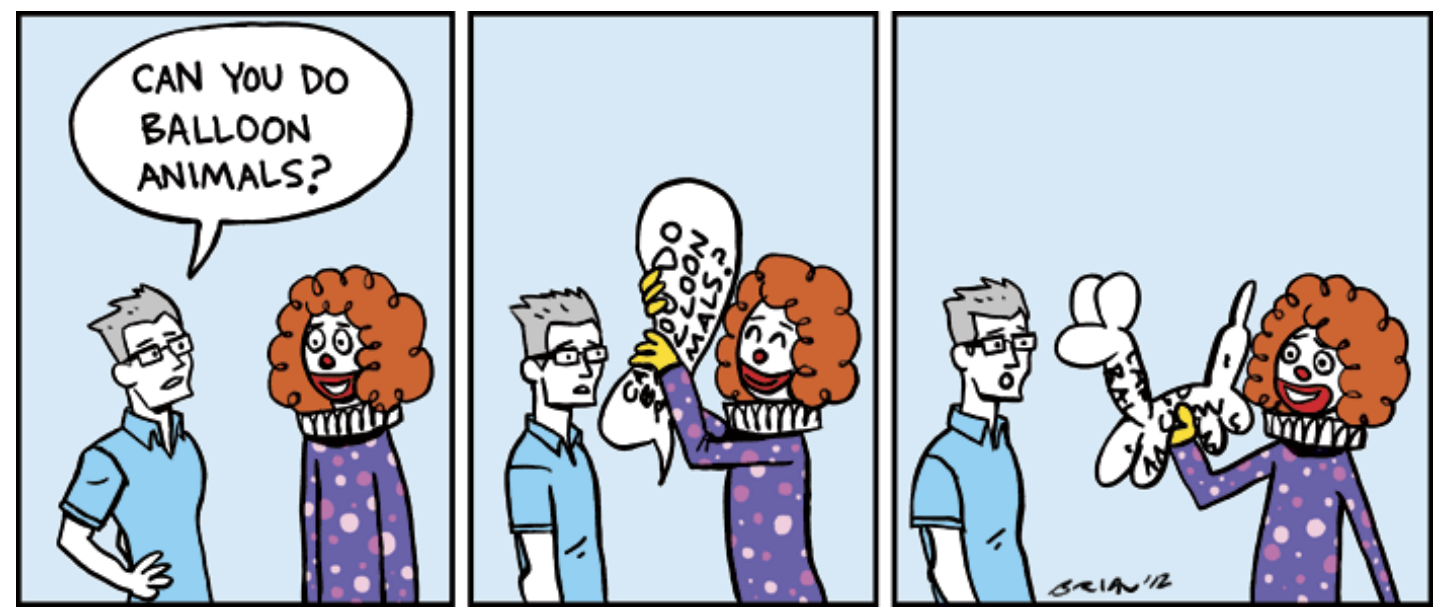

Fonte: http://www.brianmcl.com/page/13/ (2014)

Como Eisner (apud Inge, 2011, p. 56) aponta, é mais comum encontrar usos criativos do letreiramento em quadrinhos de humor, afinal, a própria fuga do convencional pode constituir uma piada. Contudo, a metalinguagem dos balões aparece também em outros gêneros.

Na Figura 60, a seguir, os balões de fala continuam representando a fala, mas como se esta fosse um objeto invisível e errante. Através do símbolo do locugrama, mostra-se o trajeto do discurso de um dos personagens até a mente do outro. Pela quantidade de balões, infere-se que várias ideias são expostas, mas apenas uma é absorvida pelo ouvinte. 
Figura 60. Parte de tira usando metaquadrinhos, por Alex Norris, 2013
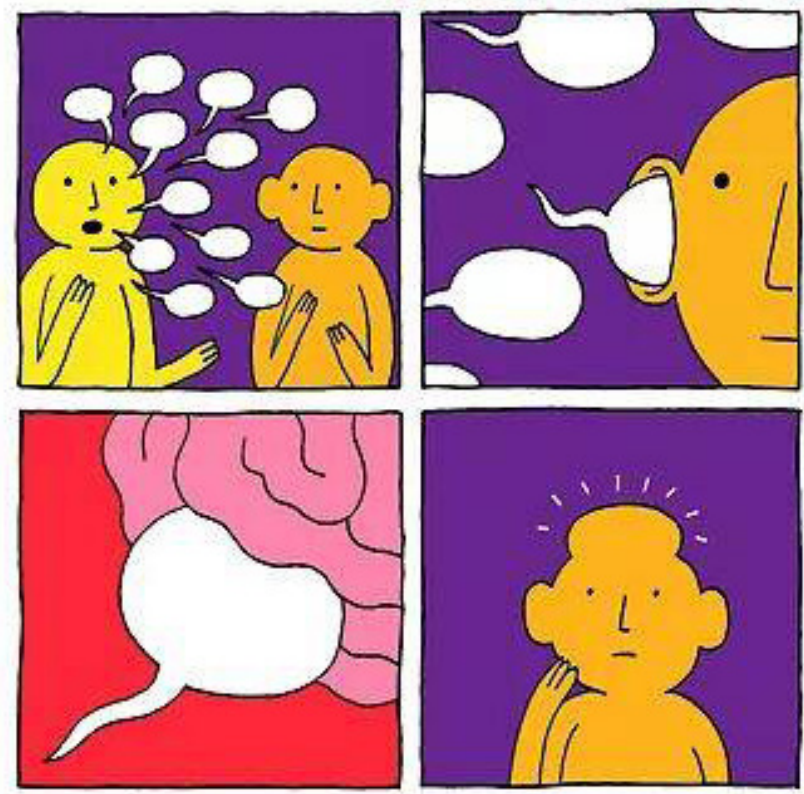

Fonte: http://dorrismccomics.com/post/64681231561 (2014)

O letreirista Joe Caramagna faz uso do metabalão em Daredevil de forma a contribuir com o suspense na cena, vista na Figura 61. Após despedir-se do protagonista ruivo Matt Murdock, o senhor Benson revela ser comparsa de seu maior inimigo. Este é um momento em que o voto de confiança que Matt e os leitores da revista depositaram na inocência do advogado bigodudo é subitamente quebrado, e a oportunidade de enfrentá-lo diminui conforme as portas do elevador se fecham. Senhor Benson é inalcançável, juntamente à sua declaração, que aparece em um balão parcialmente oculto. Os dois, personagem e confissão, escapam pela fresta e deixam Murdock frustrado.

Figura 61. Balão parcialmente oculto em Daredevil n 26, por Mark Waid e Chris Samnee, 2013
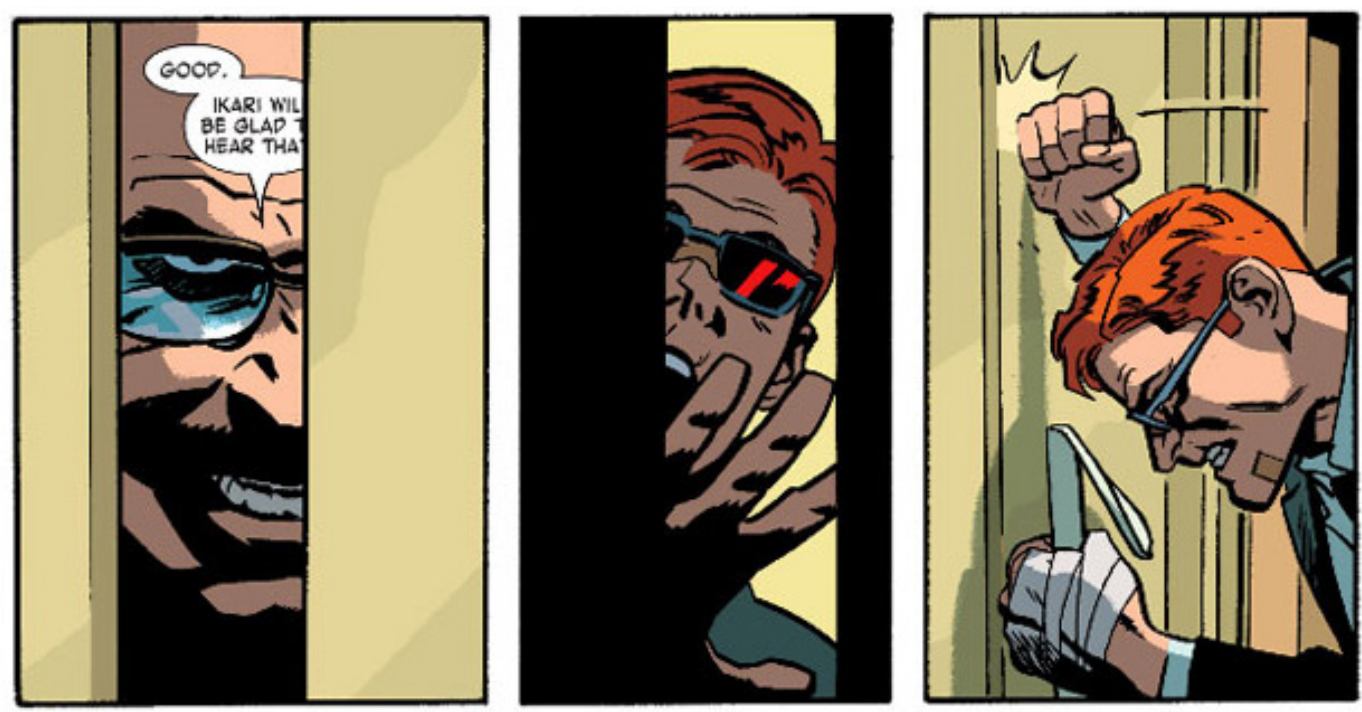

Fonte: http://www.theothermurdockpapers.com/2013/05/Scary-elevator-DD26.jpg (2014) 


\subsubsection{Letreiros e anúncios}

Para narrações em terceira ou em primeira pessoa, externas à cena principal, usa-se um suporte retangular conhecido como caixa narrativa ou letreiro, cujo uso também é verificado para anúncios. Sua simplicidade e seu contorno geométrico oferecem destaque tanto nas ilustrações detalhadas quanto em imagens mais limpas de traços. Para causar mais contraste ou mesmo para torná-las mais atraentes, as caixas podem apresentar sombras, cores berrantes ou diferentes formatos, comumente representadas como filactérios carcomidos e faixas dobradas. No caso dos anúncios, é corrente o uso de bordas dentadas. (Figura 62)

Figura 62. Diferentes tipos de anúncios: retangular, dentado e com sombra.
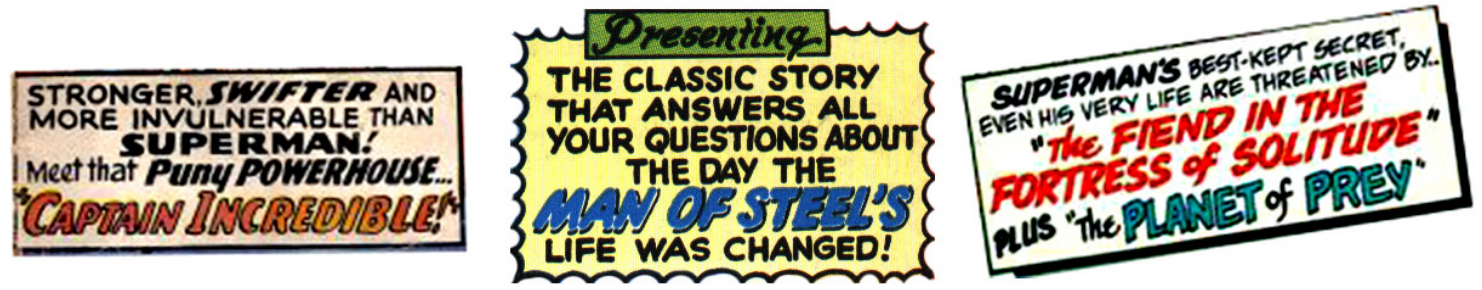

Fonte: capas de volumes variados de Action Comics

Nos anos 60, muitos gibis dispunham de espaço próprio para propagandas. Para separar os títulos anunciados, cada um deles era blocado em uma caixa inclinada, com diferentes angulações.

Figura 63. Anúncio em história em quadrinhos, por Ira Schnapp, 1962

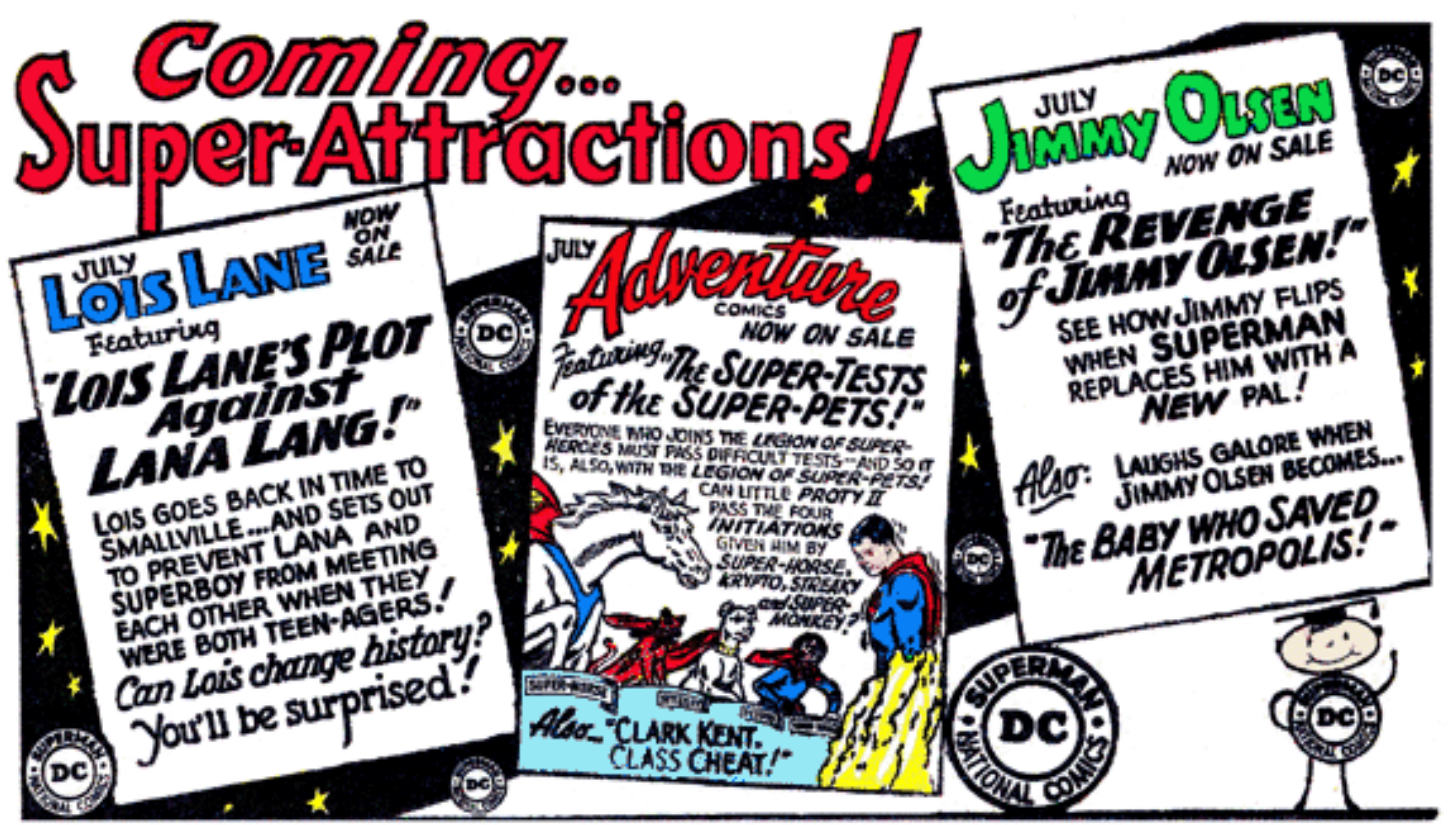

Fonte: http://www.dialbforblog.com/archives/375/ (2014) 
O desenho da caixa pode servir apenas para separar o texto da imagem, assim como pode ter finalidade decorativa ou propor a época em que a história ocorre (remetendo a um papiro, por exemplo). No caso de conteúdo em primeira pessoa, pode-se passar a ideia do suporte onde a narração, a citação ou a reflexão foi escrita, como no caso de letreiros simulando tiras rasgadas de papel com a escrita em letras cursivas, indicando que o texto foi originalmente escrito em uma carta ou em um diário.

As caixas narrativas da Figura 64 representam a interface do software que o personagem está utilizando. Assim, fica claro que o texto não se refere ao seu monólogo interno, e sim reproduz exatamente o que está sendo digitado.

Figura 64. Caixa narrativa indicando suporte digital

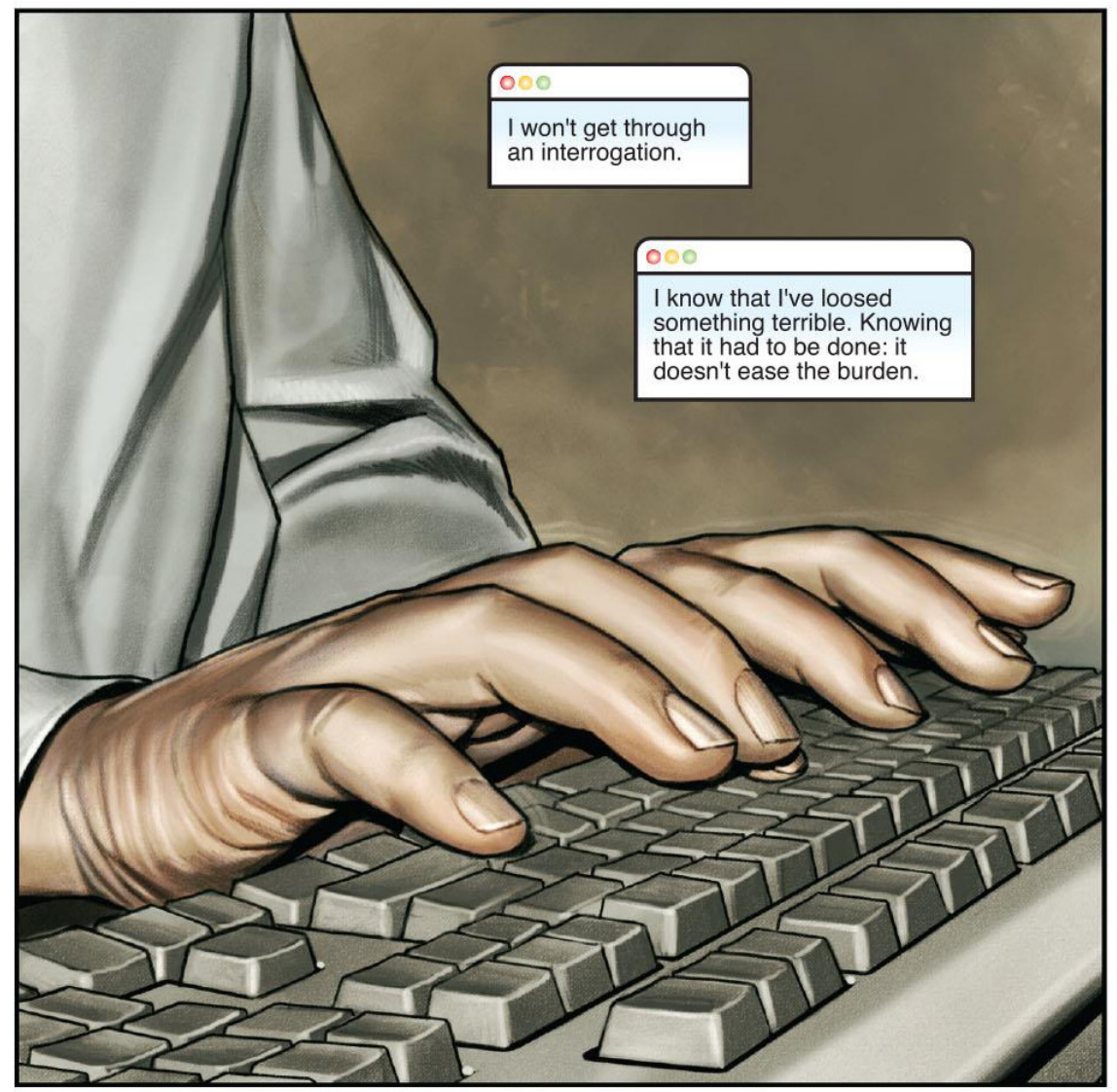

Fonte: ElLIS; GRANOv, 2005, p. 11 (letras por Randy Gentile)

Mais além, alguns quadrinistas integram o letreiro ao estilo do desenho e transformam-no em parte da arte em vez de manter o típico retângulo, o qual pode aparentar um elemento intruso, invasivo, posto no quadro apenas como medida desesperada. Na obra Habibi, Craig Thomson emoldura seus textos com bordas ao estilo árabe (Figura 65), que evoca o Oriente Médio, onde se passa a história, e mostra como o desenho dos letreiros pode colaborar com a estética do livro. 
Figura 65. Letreiro com bordas desenhadas em Habibi

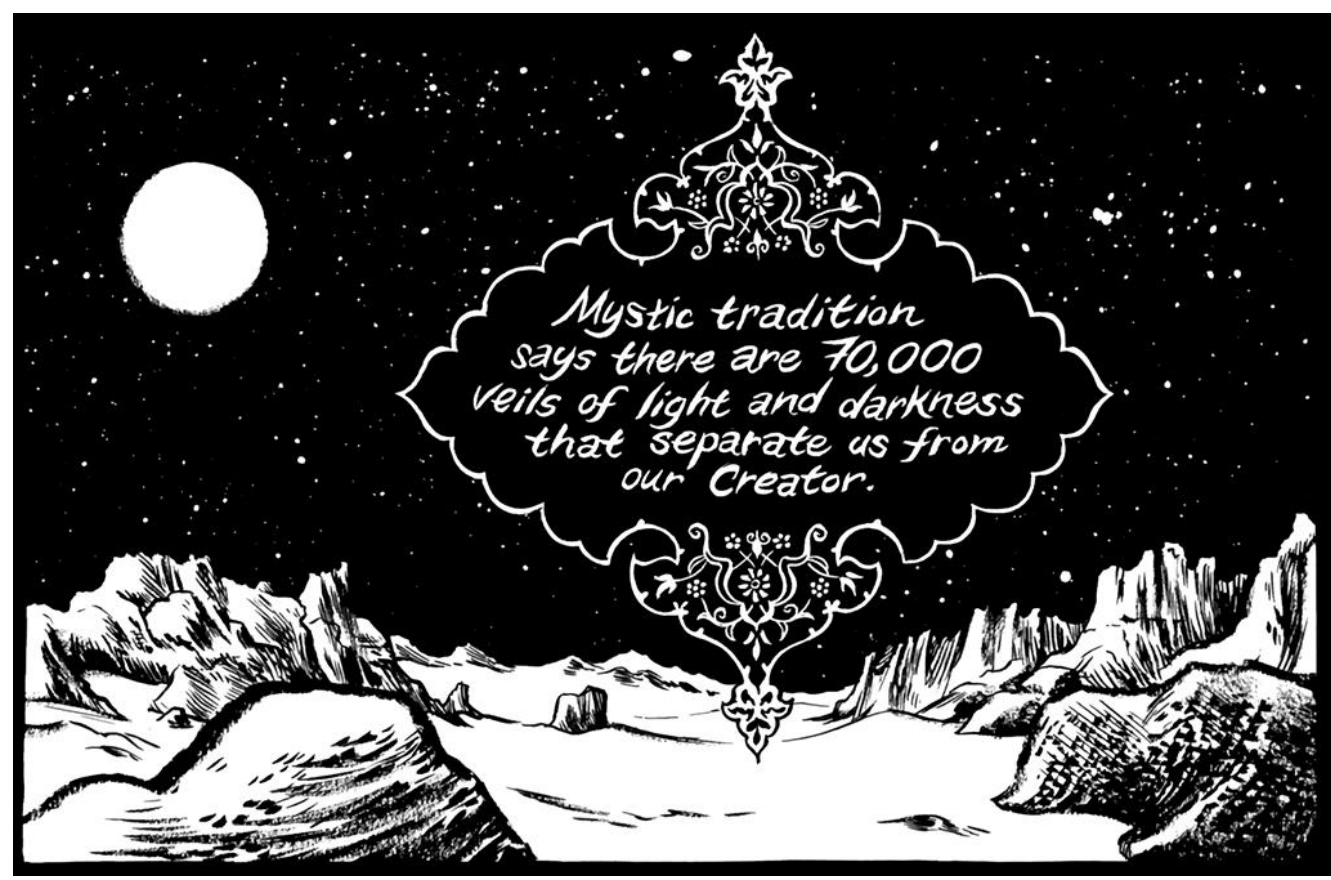

Fonte: THOMPSON, 2011, p. 93

O tipo de letra desses suportes comumente se difere daquele usado para os diálogos nos balões, seja usando uma grafia diferente, seja usando o itálico. Para diferenciar as funções desempenhadas pelos letreiros, Piekos (2013) recomenda o uso de um asterisco para as notas de cunho editorial e aspas no caso dos monólogos internos - as aspas devem abrir e fechar em cada caixa, não importa se contiverem uma reflexão contínua. Os textos narrativos frequentemente se iniciam com uma capitular que ultrapassa as bordas do retângulo, fazendo com que sua chamada seja mais vistosa. (Figura 66)

Figura 66. Exemplos de letreiros, por Nate Piekos, 2013

\section{CAPTION IDEA 1}

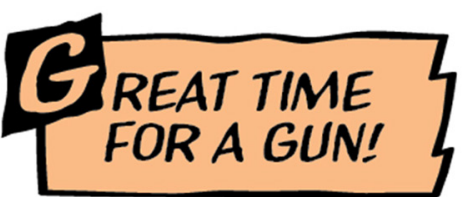

CAPTION IDEA 3

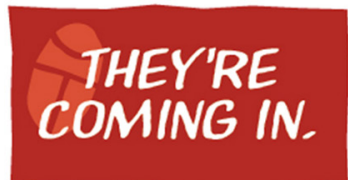

CAPTION IDEA 2

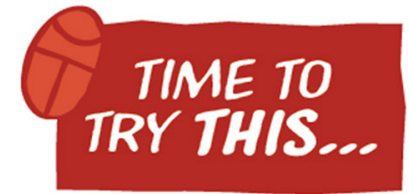

CAPTION IDEA FINAL

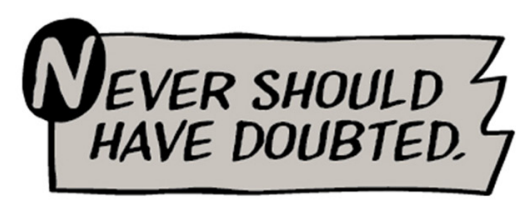

Fonte: http://www.darkhorse.com/Blog/1242 (2014) 
Nas opções representadas pela figura anterior, nota-se que nas ideias 2 e 3, Nate Piekos procurou usar o desenho de um besouro, fazendo alusão ao protagonista da série em questão, o Besouro Negro. Trata-se de uma estratégia bastante utilizada para reforçar a marca de um personagem, principalmente em histórias de super-heróis, (Lainé; Delzant, 2010, p. 71) como, por exemplo, um relâmpago para o Flash (Figura 67) ou um morcego para o Batman.

Figura 67. Caixa narrativa de Flash com o desenho um relâmpago

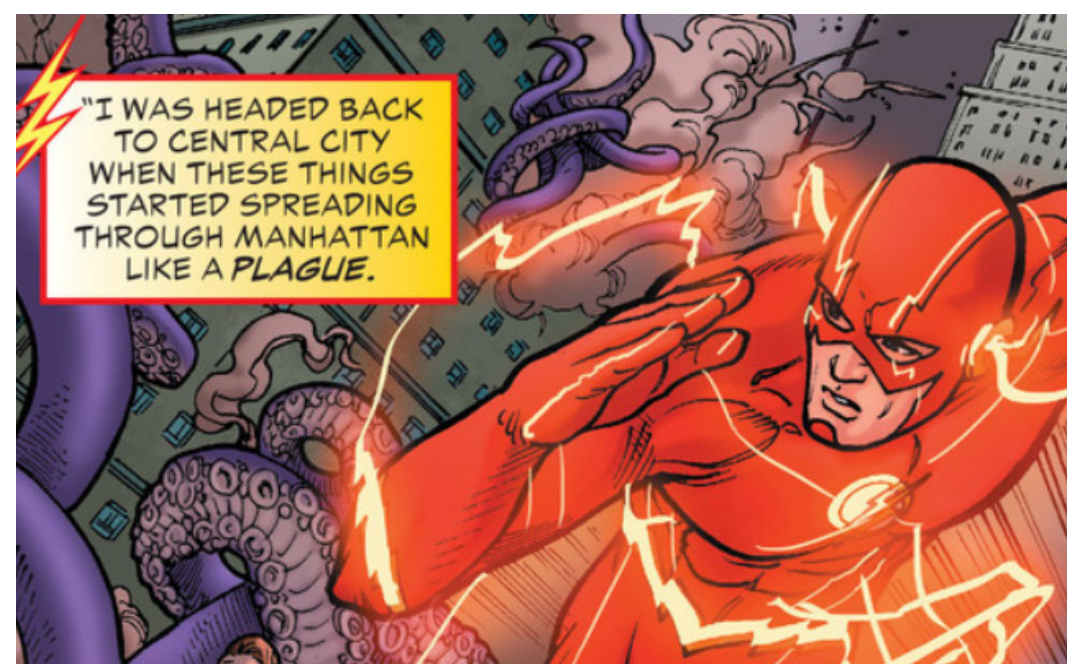

Fonte: http://new52flash.blogspot.com.br/2013/09/justice-league-dark-20.html

Os mangás, por outro lado, mantêm a caixa narrativa sem muitos detalhes, possivelmente por serem em preto e branco: sem o auxílio de cores, é mais fácil destacar a caixa em meio aos desenhos em nanquim pelo fator simplicidade. Muitas vezes, para deixar o quadro ainda mais limpo, até as bordas dos retângulos são eliminadas, como é analisado a seguir.

\subsubsection{Sem suporte}

Quando há bastante espaço em branco nas ilustrações, as bordas dos letreiros podem ser dispensadas e o texto narrativo ou o anúncio de "Continua" aparece no céu, no chão, ou em um campo onde não haja intervenção no desenho. Nos mangás, porém, é natural encontrar narrações por cima das figuras, sem o auxílio de caixa narrativa.

Observa-se na figura a seguir que a solução adotada para destacar o texto foi aplicar um contorno branco nos caracteres. Não raro, os mangakás, quadrinistas japoneses, tiram máximo proveito da página com desenhos e a única maneira de adicionar a narração é colocá-la sobre os traços em nanquim. Para prezar os detalhes, a medida do contorno é mais coerente do que o uso de letreiros, os quais cobririam uma área ainda maior da arte. 
Figura 68. Texto posto por cima da ilustração em Rurouni Kenshin, por Nobuhiro Watsuki, 1994

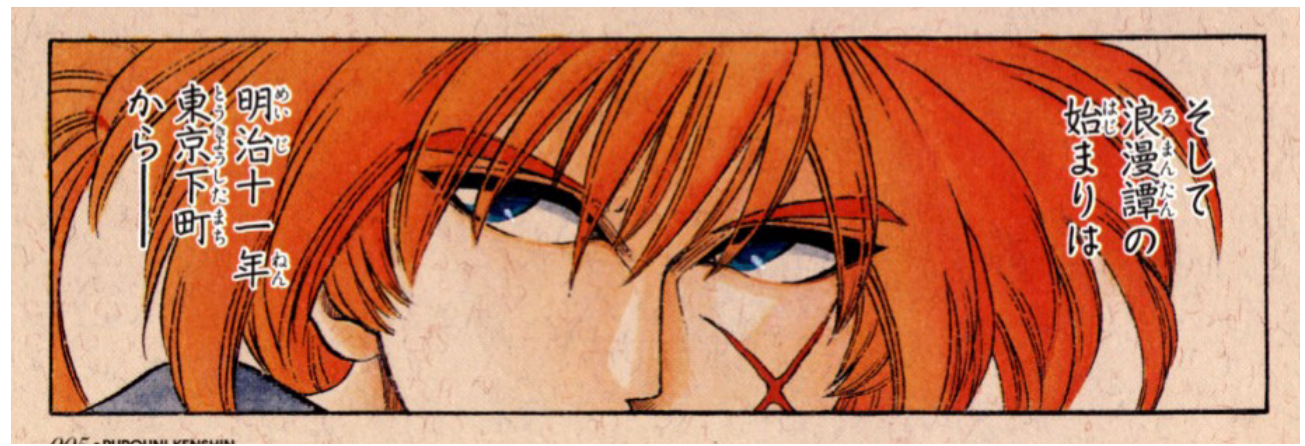

Fonte: WATSUKI, 2006, p. 5

Além dos balões nuviosos e dos balões espinhados, os quadrinhos nipônicos também costumam representar o monólogo interno sem qualquer suporte. $\mathrm{Na}$ figura a seguir, a reflexão da personagem Alice é mostrada tanto dentro dos balões com rabicho de bolhas quanto sem suporte. No texto do canto superior direito, nota-se o recurso do contorno branco para distinguir as letras dos detalhes do cenário.

Figura 69. Duas formas de representar o pensamento em mangá

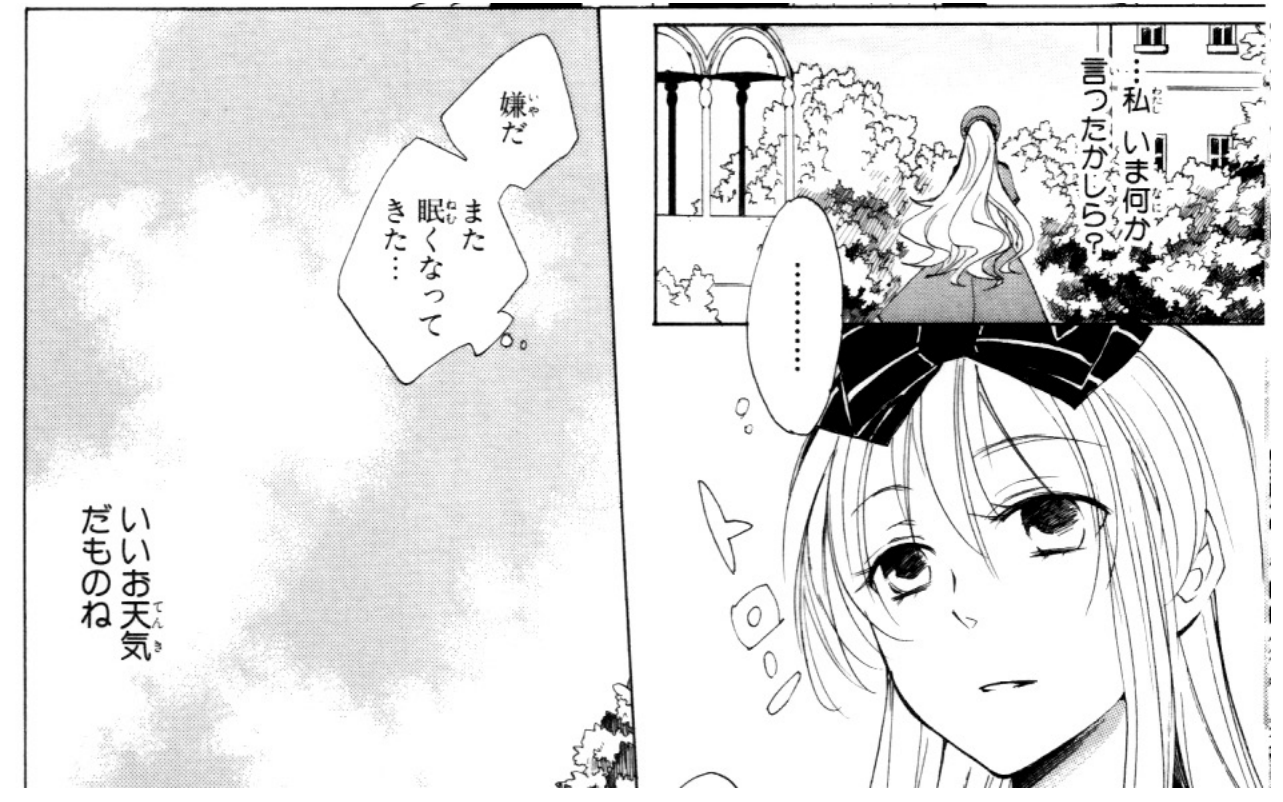

Fonte: QUINROSE; FUJIMARU, 2011, p. 14

Textos articulados geralmente muito curtos também podem surgir sem qualquer suporte, contanto que situados perto da cabeça do personagem, para que fique claro quem é o emitente. São frequentemente sinais de pontuação (como "?!") ou interjeições ("yay", "mas", "não"). (Lainé; Delzant, 2010, p. 28) Na Figura 70, constata-se no segundo painel um som emitido oralmente, porém sem balão de fala. Como apenas o Calvin está presente no quadro, fica evidente que é ele quem solta um resmungo ininteligível, carregado de sono. 
Figura 70. Fala sem balão

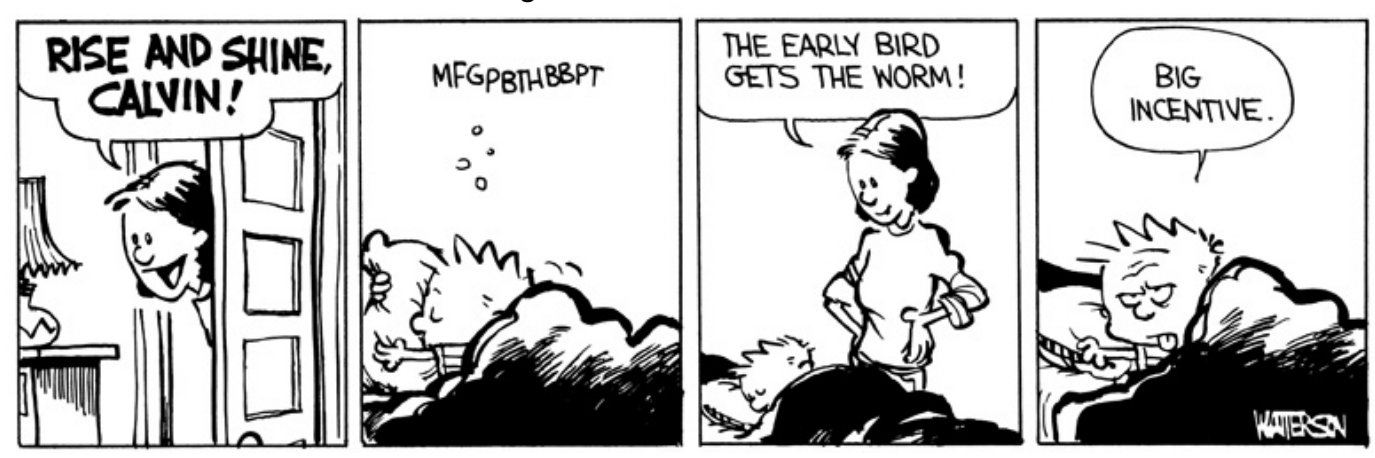

Fonte: Calvin \& Hobbes, por Bill Watterson, 1986

No Japão, falas maiores são usadas sem balão quando denotam comentários à parte da história, sem importância para a trama. Na maioria das vezes, são observações irônicas, como se fosse dito pelo canto da boca ou em volume mais baixo. Vários exemplos de uso são verificados na Figura 71. Com exceção do texto em negrito no painel à direita, que imita o barulho da sucção da bebida pelo canudo, todos os textos encontrados na figura são falas. No quadro à direita, o texto não-balonizado apresenta-se próximo à personagem Misuzu para que os leitores saibam quem o proferiu, mas no quadro superior esquerdo não há qualquer personagem. Desta forma, identifica-se o falante de cada locugrama pelo contexto e as falas sem suporte são inseridas perto do balão de seu emissor. No quadro inferior esquerdo, nota-se outra prática frequente nos mangás: a interjeição é colocada no canto do balão, não respeitando suas bordas.

Figura 71. Exemplos de fala fora de balões

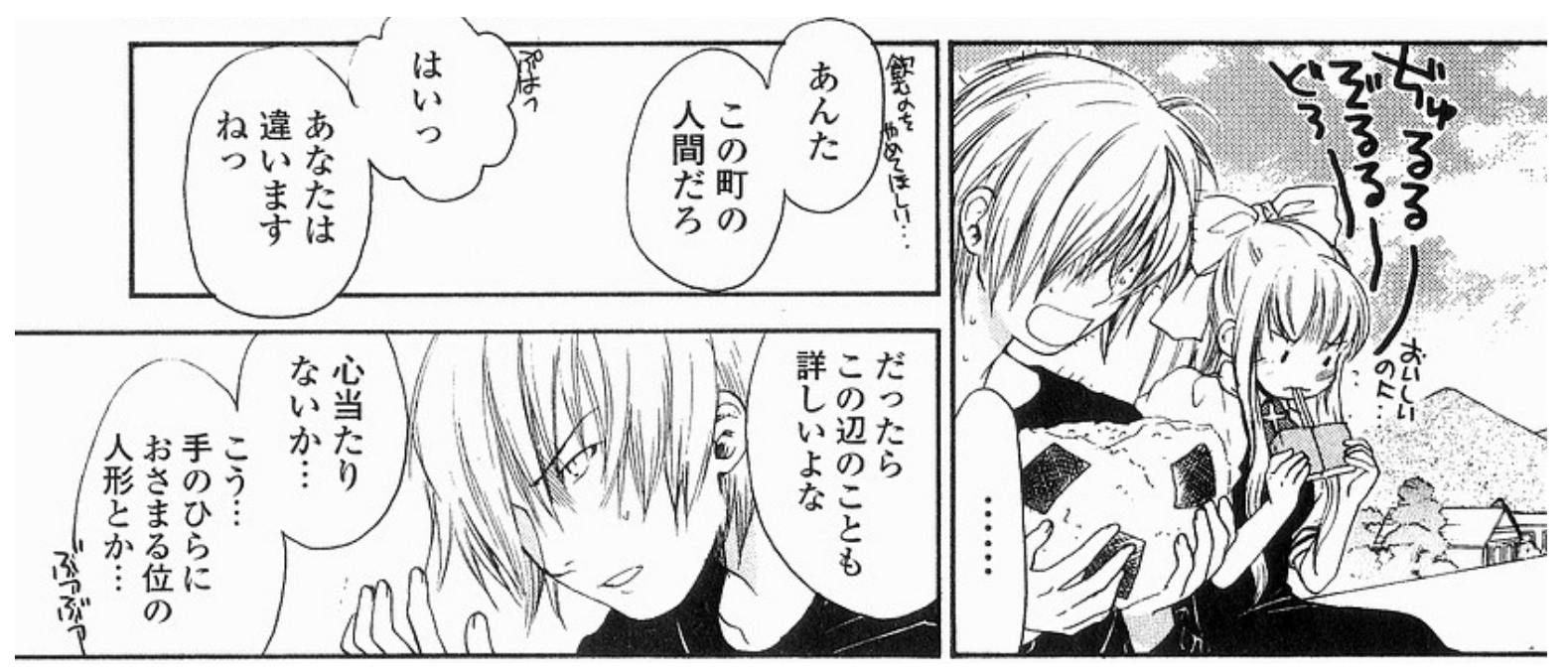

Fonte: KATSURA, 2005, p. 08

Percebe-se também que essas falas são escritas à mão, e não digitalmente como nas falas normais. Esse método facilita o encaixe do texto, o qual é frequentemente inclinado, e diminui o contraste entre as letras e a arte. 


\subsubsection{Disposição dos suportes}

A distribuição dos suportes pela página exige alguns cuidados para facilitar a leitura. Uma das regras mais intuitivas é colocá-los de forma a não cobrir elementos importantes da cena, como a cabeça do personagem. Para tanto, a etapa da ilustração deve favorecer a existência de locais apropriados para manifestarem os suportes. A área mais indicada a ser desocupada é na parte superior de cada quadro (Lainé; Delzant, 2010, p. 14; Toriyama; Sakuma, 2002, p. 114; Roshell; Starkings, 2003, p. 30), de maneira que os balões fiquem acima ou à altura da cabeça do falante. Assim como um balão de látex inflado à gás hélio, os balões de fala devem voar, com exceção de casos de indisponibilidade de espaço. É preferível deixá-los na parte inferior a permitir que invadam outros quadros.

Outro consenso entre letreiristas concerne os rabichos: Nate Piekos ${ }^{20}$, Chris Oatley $^{21}$ e Patrick Brosseau ${ }^{22}$ recomendam que os apontadores devem emanar do centro do balão para a boca do personagem falante, e os balões devem ser posicionados para que os rabichos não se cruzem.

Os mesmos profissionais lembram que o ar do balão ou área de respiro, ou seja, o espaço entre a borda do locugrama e a escrita, deve ser consistente para todas as falas da história. Para ajudar iniciantes no ramo, há uma regra de ouro onde essa área deve ser visualmente igual à altura de uma letra contida no balão. (Lainé; Delzant, 2010, p. 55) Os gibis asiáticos costumam ser mais generosos nesse quesito, seguindo a praxe de balões grandes e falas reduzidas.

Figura 72. Balões de quadrinhos coreanos são bem espaçosos

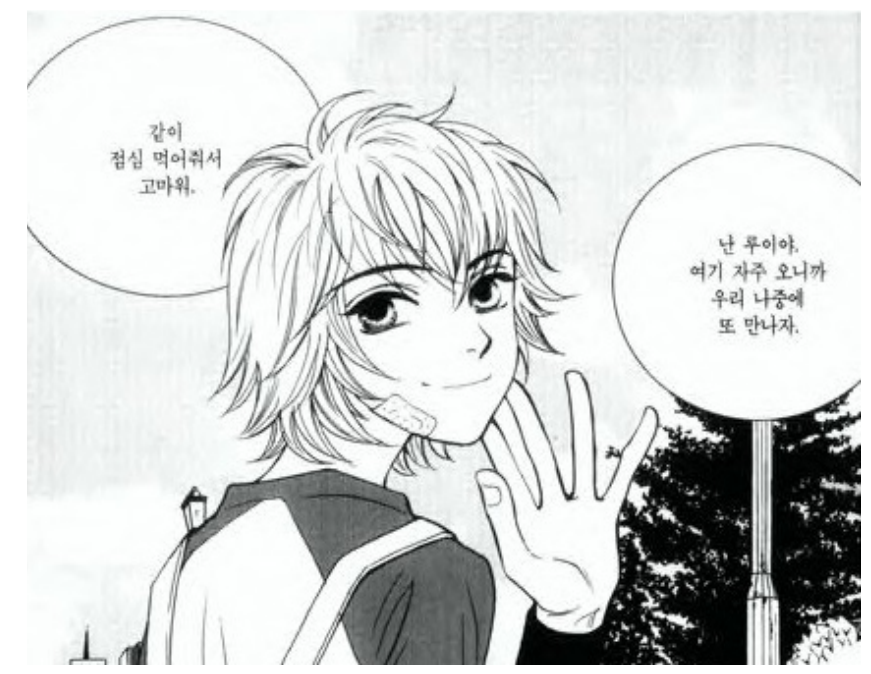

Fonte: YERI, 2005, p. 14

20 Learn lettering with Nate Piekos. Comics worth reading, jun. 2012.Disponível em: <http:// comicsworthreading.com/2012/06/09/learn-lettering-with-nate-piekos/>. Acesso em: out. 2014.

21 Comic layout tutorial: the comic lettering spell. ChrisOatley.com, jul. 2012. Disponível em:

<http://chrisoatley.com/comic-lettering-comic-layout/>. Acesso em: ago. 2014.

22 Pointers. Comic book lettering tips, out. 2013. Disponível em: <http://comicbookletteringtips. tumblr.com/post/64498255055>. Acesso em: out. 2014. 
Apesar de a função fundamental do suporte ser o realce do texto, um dever do letreiramento é impedir que os suportes se destaquem em demasia, como que saltassem da ilustração. As letras e seus recipientes devem ser parte da página, em harmonia com o estilo do desenho nela composto. Na Figura 73, temos a situação de uma arte onde o traço à lápis e a colorização suave tornam as cores branca e preta sobressalentes. Para resolver esse desafio, Todd Klein abriu mão do branco puro em troca de um tom claro para os balões e a borda também não é totalmente preta, mas composta de uma mistura de cores para auxiliar a interação visual com o ambiente colorido ${ }^{23}$. Outra solução para esse tipo de problema seria adicionar um grau baixo de transparência.

Figura 73. Solução para balões se mesclarem com ilustrações coloridas

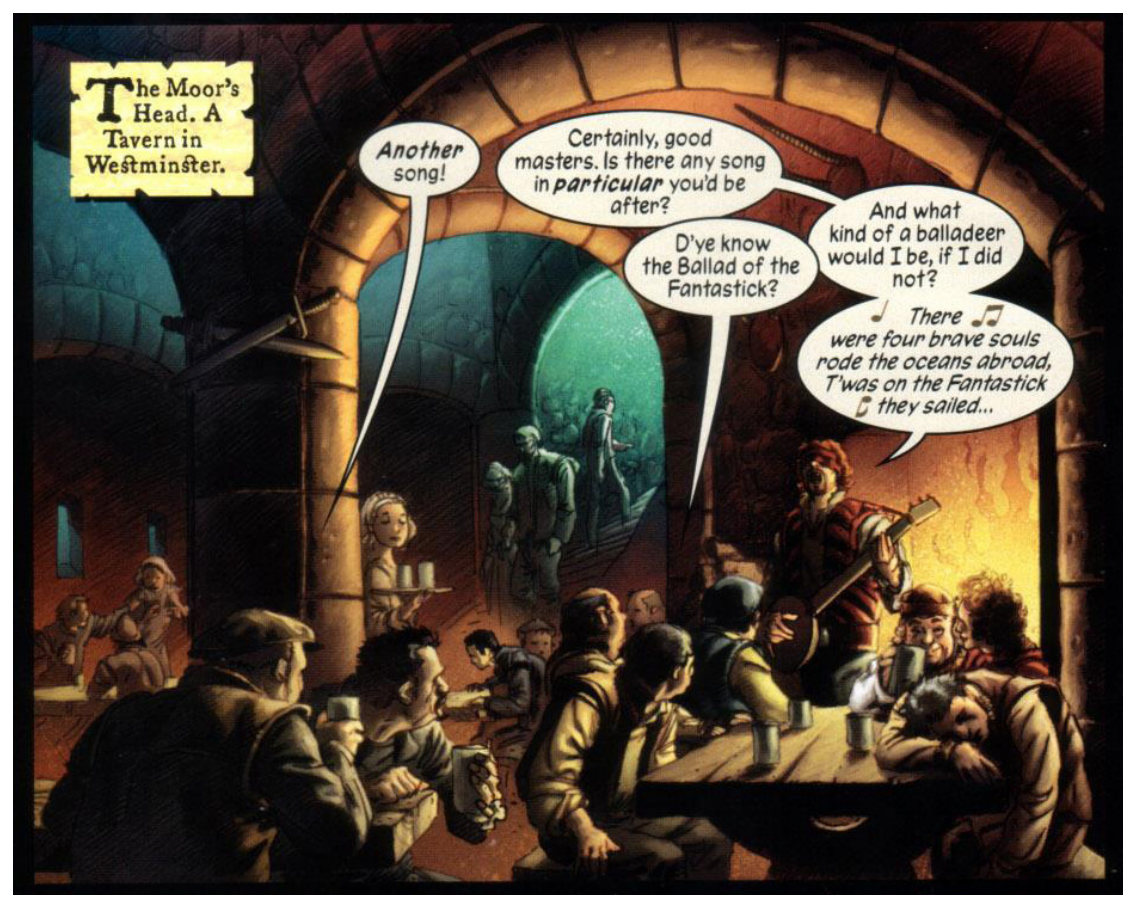

Fonte: GAIMAN, 2003, p. 10 (letras por Todd Klein)

Na imagem anterior, a fala do trovador é dividida em vários balões. Isso ocorre quando é muito extenso (Toriyama; Sakuma, 2002, p. 117) ou quando reflete ideias muito distintas. No caso de haver pouco espaço no quadro, os balões de um mesmo emissor podem ser conectados ligando-os através de um rabicho, como no primeiro e segundo balões do bardo, ou fundindo seus cantos como no segundo e terceiro balões do mesmo personagem. Toriyama (2002, p. 115) aconselha evitar colocar mais de três balões por quadro, mas é comum encontrar quatro ou mais por painel em quadrinhos norteamericanos, prática que ajuda a guiar o olhar do leitor pelo desenho, como será visto adiante.

$23 \quad$ Lettering roundtable: the case regarding upper \& lower case lettering. Mesa redonda, jan. 2004. Disponível em: <http://www.balloontales.com/articles/roundtable/index.html>. Acesso em: jul. 2014. 


\subsubsection{Temporização}

O tempo é um dos componentes essenciais para atribuir realidade às mídias visuais. Como as histórias em quadrinhos são compostas por imagens estáticas, o movimento é expresso por meio de ilusões causadas no leitor quando este procura auto-completar os acontecimentos no intervalo entre um quadro e outro. Essa sequência de eventos, os visualizados e os imaginados, provocam o reconhecimento da passagem de tempo.

Segundo McCloud (2005, p. 96), "nossos olhos foram treinados pela arte fotográfica e representacional pra ver qualquer cena como um único instante". As histórias em quadrinhos dispõem de elementos que confrontam essa instantaneidade da imagem, os balões. Com auxílio desses suportes flutuantes, torna-se possível propor a duração do quadro na história porque eles transportam algo que só pode existir no tempo: o som. A palavra não é imediata; ela toma tempo para ser proferida. Assim, quanto mais diálogos no painel, mais longa é a ação ali representada (Lainé; Delzant, 2010, p. 46). McCloud aproxima o decorrer do tempo a uma corda que passa por todos os balões de um quadro conforme sua ordem de leitura, onde cada polegada da corda representa um segundo.

Figura 74. Representação da passagem do tempo como uma corda pelos balões de fala

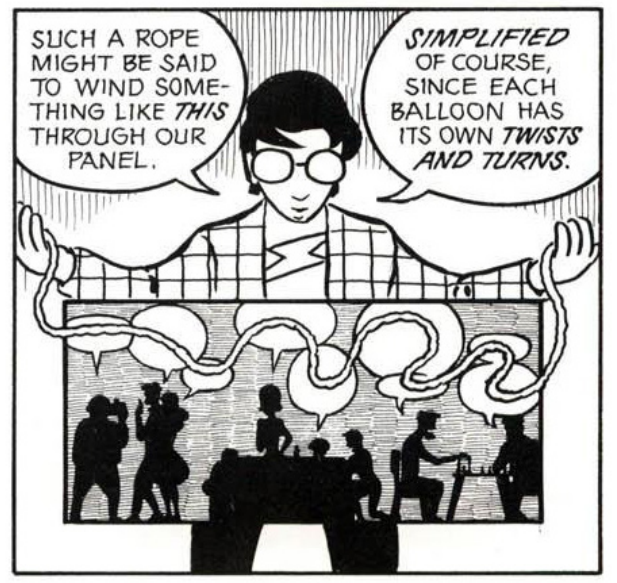

Fonte: MCCLOUD, 2010, p. 96

Para que o desenho fosse mais representativo, o barbante teria que passar por cada linha de texto dentro do balão. Assim, marcando o início e o final do quadro no fio e esticando-o, ter-se-ia uma noção aproximada do tempo decorrido para a leitura das falas.

Eisner (2010, p. 26) compara a tira de quadrinhos com o código Morse ou uma notação musical, que também incluem o uso do tempo, e equipara os símbolos próprios de cada expressão aos balões de fala, com auxílio do tamanho dos quadros para imitar o compasso. 
Figura 75. Comparação das tiras em quadrinhos com outras formas de expressão
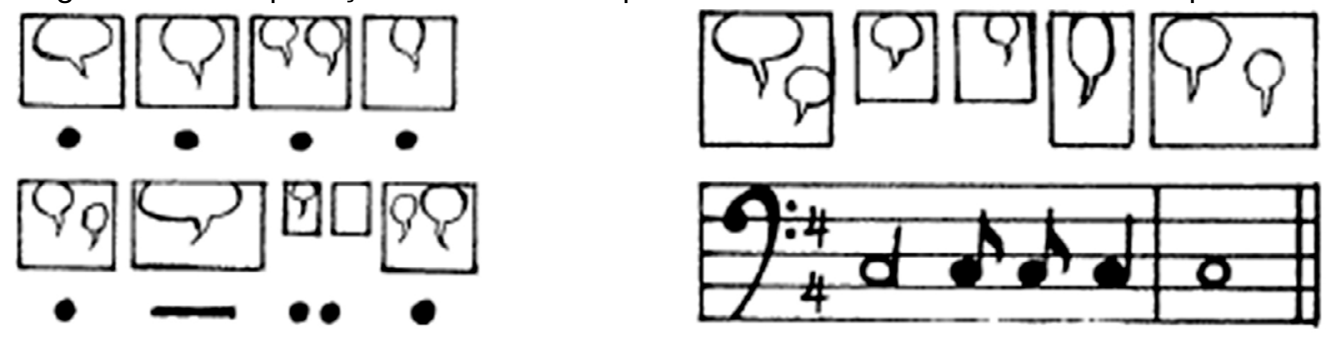

Fonte: EISNER, 2010, p. 26

A pausa que o leitor faz para direcionar o olhar de um balão para o próximo ajuda a determinar o ritmo da história. Dois balões distantes um do outro podem indicam um breve período de silêncio entre eles, assim como vários balões sobrepostos suscitam uma conversa esbaforida.

Na Figura 76, a quebra de uma ilustração em três quadros obriga o leitor a seguir a imagem da esquerda para a direita em vez de vê-la imediatamente por inteiro, com efeito similar à de uma filmagem que move a câmera pela cena. A fala cortada em balões longíquos entre si delonga o ritmo da leitura em uma voz arrastada que reflete a hesitação da personagem emissora. Dessa maneira, fica a impressão de um dizer pausado, oscilante, que acompanha o deslocamento quase cinematográfico pelo desenho.

Figura 76. Balões auxiliam a ditar o ritmo da história

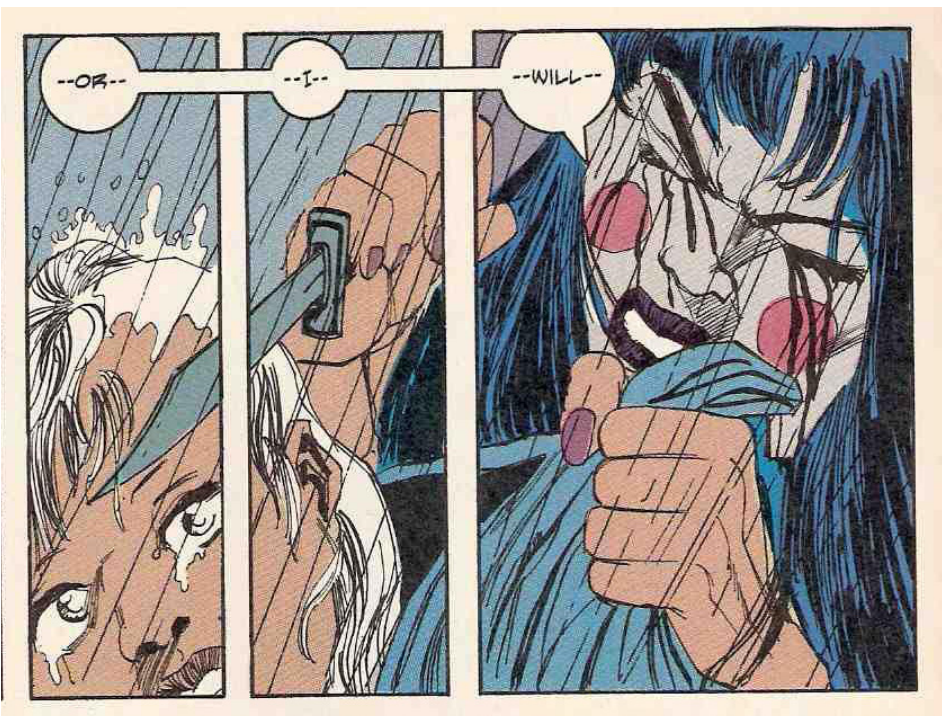

Fonte: O'NEIL; CoWAN, 1990, p. 28 (letras por Willie Schubert)

Eisner (p. 24) classifica os balões como disciplinares, visto que exigem a colaboração do leitor e necessitam ser lidos em ordem específica para que haja sentido, portanto, a disposição dos suportes precisa seguir uma lógica de modo a tornar a ordem de leitura clara e fluida. Para isso, faz-se essencial a compreensão do direcionamento instintivo do olhar dos leitores pela página. 
A leitura ocidental segue da esquerda para a direita, de cima para baixo. Isso significa que o balão mais à esquerda e/ou mais acima na imagem sempre será lido primeiro. A partir do primeiro suporte, os demais são colocados observando o princípio de que o olhar do leitor segue uma grande diagonal, onde a sucessão de pontos focais forma uma espécie de toboágua que vai guiando o leitor para o canto inferior direito do painel e retoma o canto superior esquerdo do quadro seguinte. No caso de um diálogo, a pergunta será situada mais alto do que a resposta para hierarquizar a ordem de leitura. (Lainé; Delzant, 2010, p. 27)

Como o texto é feito na direção inversa no Japão, da direita para a esquerda, o princípio de ordem de leitura que rege nos mangás é o mesmo, mas a diagonal é invertida horizontalmente.

Figura 77. Exemplo de orientação de leitura através dos balões

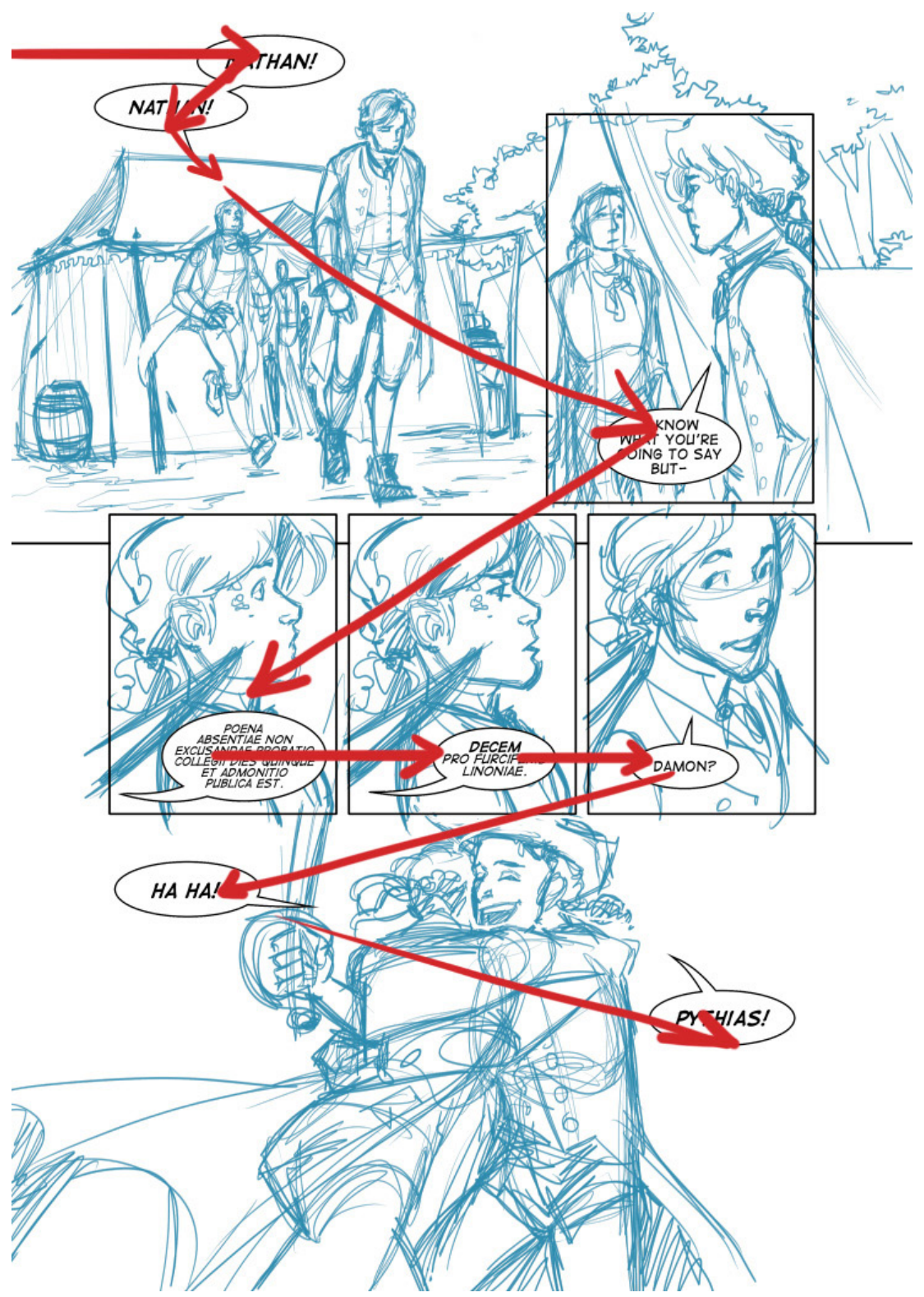

Fonte: OATLEY, jun. 2012 
O posicionamento dos balões, ao guiar o olhar do leitor, pode contribuir para levá-lo a partes específicas da imagem, evidenciando detalhes, ou para explorar a ilustração de forma abrangente, quando os suportes estão adequadamente espaIhados. Contudo, os balões também podem atrapalhar o fluxo de ação ao confrontar o senso de realidade do leitor (Eisner, 2005, p. 63). Um exemplo desse deslize ocorre quando o quadrinista exige uma noção de tempo através dos balões que não corresponde à duração esperada em um diálogo real. Eisner aponta que a fala determina a duração da postura da qual ela emana, então longas conversações são dificilmente verossímeis em imagens estáticas, pois, ou são necessários muitos quadros para mostrar as mudanças de posição dos personagens, ou estes parecem em estado estacionário durante a troca de diálogo, comprometendo a credibilidade da cena. A solução adotada pelo quadrinista deve ser o melhor elo entre diálogo e ação, que custará espaço na página ou realismo.

\section{ESTILO DE LETRA}

As histórias em quadrinhos lidam com imagens e com palavras. Embora sejam consideradas como pertencentes às duas orbes plásticas, as HQs possuem suas próprias regras. No campo textual, os fundamentos básicos de diagramação gráfica são seguidos para proporcionar legibilidade, atratividade e representatividade à leitura, mas alguns princípios são infringidos à serviço da expressividade visual.

Para a formatação de textos em geral, recomenda-se utilizar uma única família tipográfica, com exceção de fontes adicionais para compor títulos e para outras exigências que uma família não supre, como equações e alfabetos estrangeiros (Bringhurst, 2005, p. 114; Tschichold, 2007, p. 45). Seguindo esse preceito, "tem-se variedade e homogeneidade ao mesmo tempo: muitas formas e tamanhos, mas uma mesma cultura tipográfica" (Bringhurst, p. 115). Já no caso dos quadrinhos, busca-se padronizar os estilos de texto de mesma natureza, como diálogos e pensamentos, todavia, incentiva-se o uso variado de fontes, contanto que sejam cuidadosamente escolhidas para cada circunstância.

Nas produções estadunidenses, é praxe usar tipos diferentes de letra em títulos, onde artigos e preposições possuem um caráter mais discreto e sobrelevam os substantivos e os verbos. As onomatopeias frequentemente pedem por desenhos de letra particulares e os estilos são muito usados para distinguir as finalidades desempenhadas por um mesmo suporte, por exemplo, ao diferenciar um letreiro descritivo de uma caixa narrativa com monólogo interno.

Por existirem muitas situações em que vale o emprego de um estilo diverso, pode acontecer de haver uma única página com várias feições tipográficas incorporadas, como na Figura 78, composta por 14 fontes distintas. 
Figura 78. Página com uso de várias fontes diferentes

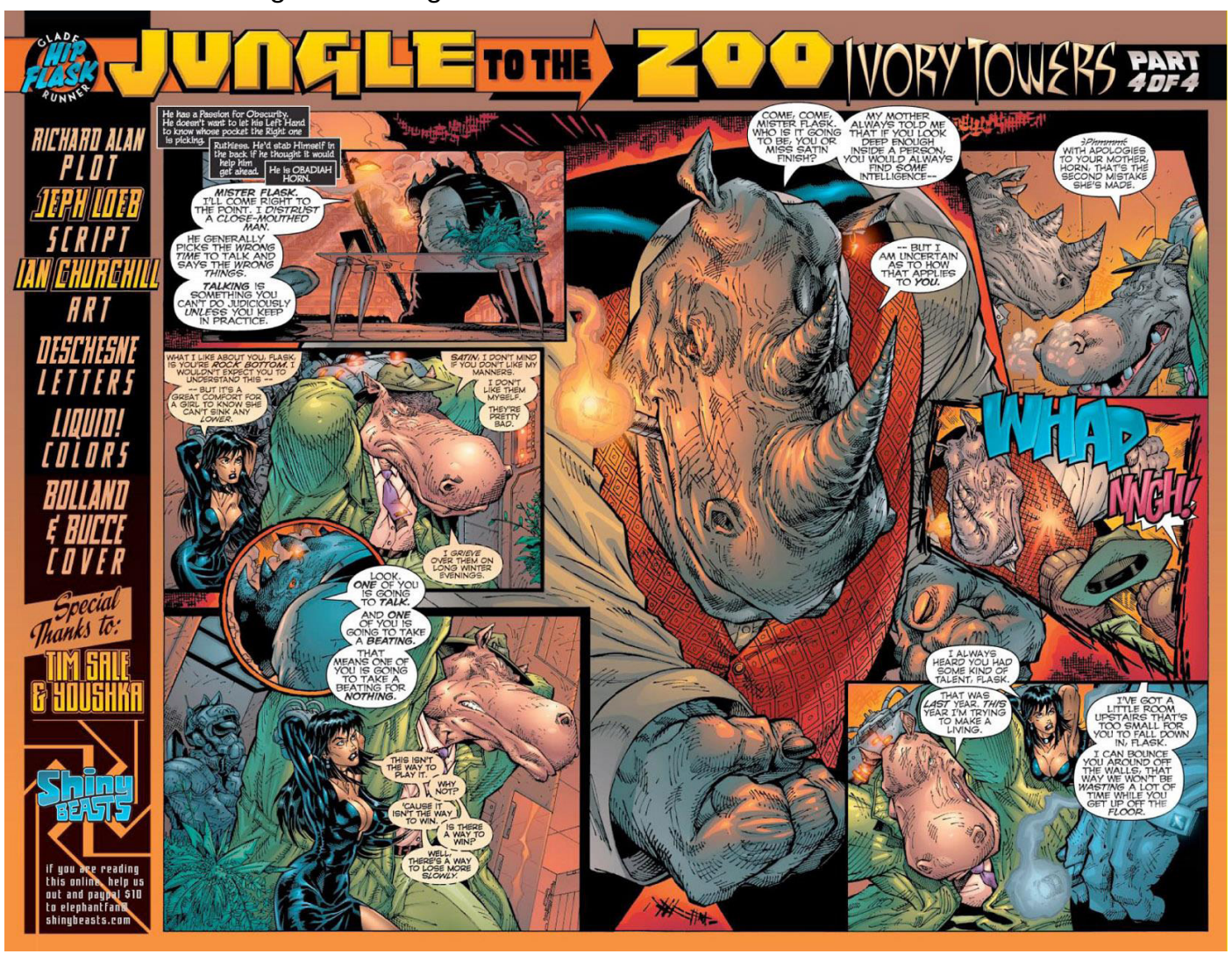

Fonte: STARKINGS, 2007, p. 29 (letras por Comicraft)

Mesmo com a ampla gama de possibilidades criativas, a trajetória histórica das HQs formou tradições que os quadrinistas costumam seguir, aproveitando a aceitação do público e evitando o estranhamento.

\subsubsection{Estilo padrão para falas}

A seção anterior explica que um estilo convencional se desenvolveu para os diálogos, devido à facilidade de feitura e à legibilidade após a impressão. É uma escrita similar à chamada "letra de arquiteto", cuja caligrafia sempre em letras maiúsculas apresenta pequenas inclinações em elementos que a compõem. Segundo Klein (2004, p. 89), tais inclinações, normalmente decaindo para a esquerda, ajudam a distinção visual das letras.

Fábricas de fontes para quadrinhos normalmente ofertam variações desse estilo, mantendo a organicidade do traço por meio de variações de espessura que remetem à escrita feita com bico-de-pena.

Para agilizar o processo, as letras geralmente não possuem serifa, com ressalva para uma variante da letra $i$. Porém, seu uso deve ser controlado: as regras informais anglófonas ditam que o $i$ serifado deve ser utilizado apenas quando designar o pronome pessoal eu (I, em inglês). (Oatley, jul. 2012) 
A restrição pode ser ignorada em situações específicas. Uma vantagem advinda do uso de computadores para o letreiramento é que o trabalho para inserir letras maiúsculas se tornou quase o mesmo para as letras minúsculas e estas têm sido aplicadas em várias obras. Como esse método também procura preservar o caráter manuscrito, os caracteres $i$ maiúsculo e o $L$ minúsculo se tornam barras verticais similares e podem ser confundidos, então a distinção é feita por meio das serifas na letra $i$ maiúscula.

\subsubsection{Formatacão do texto}

Devido à forma oval do balão, a solução mais difundida para aproveitar o espaço é centralizar o texto. Para manter a harmonia da mancha gráfica com a borda circular do suporte, a técnica empregada consiste em quebrar o texto de forma oblonga, como se estivesse encaixando-o em um losango. (Figura 79) O vácuo que circula em torno do bloco de texto deve ser homogêneo (Lainé; Delzant, 2010, p. 10).

As dicas repassadas pelos profissionais Klein (2004, p. 91), Oatley (jul. 2012), Lainé e Delzant (2010, p. 10) é de manter as maiores linhas de texto no meio e as menores no topo e na base, pois esse processo ajusta a fala aos espaços mais amplos e mais estreitos do balão, maximizando sua área. Isso quer dizer também que, em muitos casos, a linha inicial ou final do bloco de texto pode consistir em uma única palavra curta. Enquanto na composição de textos em geral, isso deve ser evitado (Bringhurst, 2005, p. 51), a diagramação nos quadrinhos frequentemente pede por esse vício. Alguns profissionais, como Oatley e Campbell (2010), impõem um limite de palavras até 3 letras, mas eles confessam que nem sempre é possível seguir essa restrição.

Figura 79. Encaixe do texto em forma de losango.

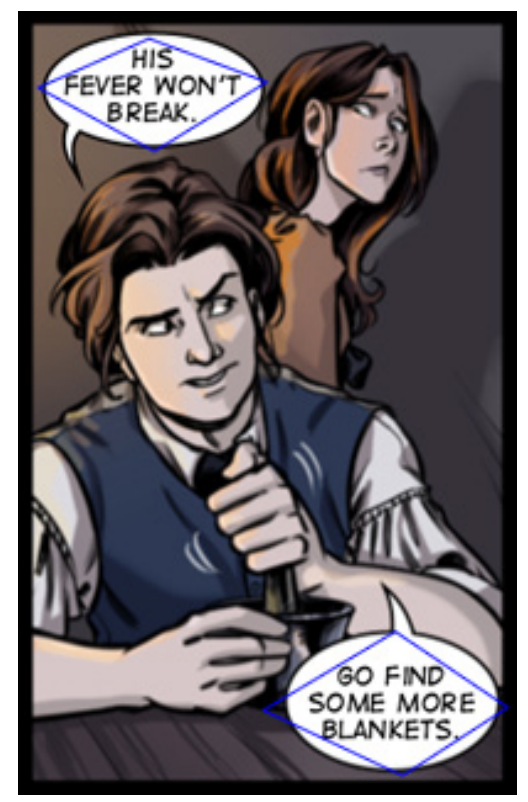

Fonte: OATLEY, jun. 2012 
Cada balão é uma unidade com seu próprio equilíbrio, e é necessário saber balanceá-las, controlando para que o aumento ou a redução de linha para linha seja suave, sem mudanças drásticas em comprimento. Ao deparar-se com falas problemáticas, Campbell e Klein (p. 91) sugerem uma saída para amenizá-las ao aumentar ou reduzir o espaço entre as palavras de uma linha ou ao modificar a escala horizontal dos caracteres, mas a transformação deve ser discreta e realizada apenas em emergências.

Os dois autores, junto a Lainé e Delzant (p. 68), apresentam outra solução que também deve ser usada com moderação: forçar a quebra de palavras. Oatley aconselha a evitar sempre que possível, já que muitas palavras não são lidas facilmente quando hifenizadas.

Essas determinações são aplicáveis para qualquer obra em quadrinhos que use o alfabeto romano. Existem particularidades das escritas orientais que devem ser explicadas para que se faça entender sua formatação específica.

A regra de organizar o texto centralizado e em forma oval se sustenta nos manhwas porque o sistema coreano possui muitas similaridades com o latino, como a escrita em linhas horizontais, o uso de espaços, a pontuação e a mesma orientação de leitura. Uma das principais diferenças é que os caracteres são arranjados em blocos silábicos, seguindo a lógica fonológica, para formar palavras. No entanto, isso não interfere na diagramação.

Figura 80. A escrita coreana é em linhas horizontais, da esquerda para a direita, com espaço entre palavras. O texto nos balões é centralizado.

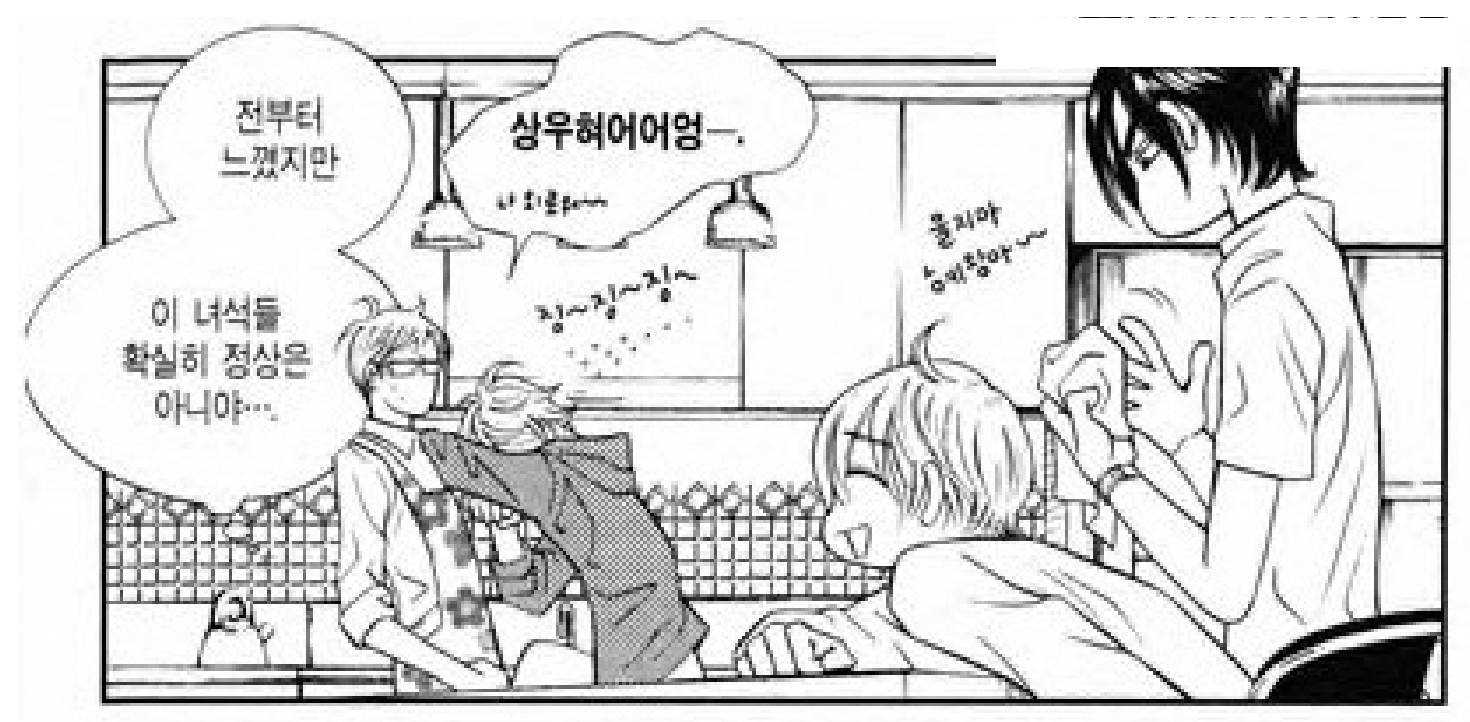

Fonte: Yeri, 2005, p. 79

Já as escritas japonesa e chinesa são da direita para a esquerda, sem espaço entre as palavras, em linhas verticais. Nos quadrinhos, em vez de centralizados, os textos são alinhados à parte superior, ignorando a curva do balão. A quebra de texto também não leva em consideração o formato do suporte. 
A pontuação, nos dois modelos, ocupa o espaço de um caractere, independentemente se é composta por mais símbolos, como no caso das reticências ("...") e do interrobang (ou ponto exclarrogativo, "?!"). Nos manhuas, quadrinhos chineses, cada caractere é visto como uma unidade independente, ou seja, não há regras que conectem os sinais de pontuação às palavras, como no sistema latino, em que, por exemplo, o ponto final e a vírgula devem vir colados à palavra anterior. Pelo contrário, é normal encontrar linhas começando por um sinal de pontuação ou encerrando com um sinal de aspas que abre para a linha seguinte.

Os logogramas chineses possuem tamanhos similares, pois cada um deles deve caber em um mesmo espaço quadrado predefinido. Assim, a distribuição do texto em um balão é feita de forma que todas as linhas tenham o mesmo número de caracteres, tornando a mancha gráfica retangular, e não oval. No caso de impossbilidade de divisão exata, a última linha sempre será a menor.

$\mathrm{Na}$ Figura 81, tem-se uma amostra da formatação chinesa. No balão à esquerda, cada linha tem exatamente o mesmo número de logogramas. À direita, a linha do meio inicia-se por uma vírgula.

Figura 81. Exemplo de diagramação chinesa

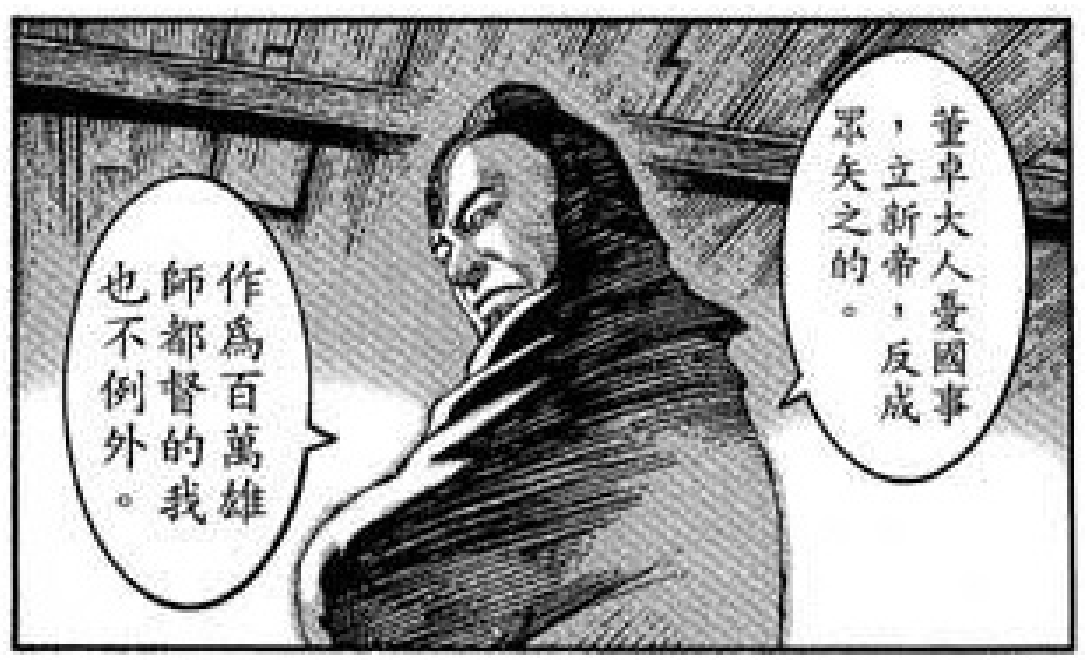

Fonte: CHAN, 2001, p. 113

As reticências e os pontos de exclamação são bastante utilizados nos mangás e ocupam, cada um, o espaço de um caractere. Uniões de sinais de pontuação, como "!!" e “...", são tomados como um símbolo só. O idioma nipônico não necessita de pontos de interrogação, pois a partícula "ka" ao final da sentença designa entonação de pergunta. Mesmo assim, esse sinal pode ser encontrado nos quadrinhos para ressaltar o sentimento de dúvida.

Os mangás não fazem uso da vírgula nem do ponto final, aproveitando a própria quebra de linha e mudança de balão para as pausas necessárias. Como alternativa, o mangaká insere espaços esporádicos para demarcar pausas na fala, normalmente após interjeições. 
Na língua nipônica, existem partículas compostas de poucas sílabas que aparecem imediatamente após substantivos, verbos, advérbios ou sentenças, desempenhando função gramatical semelhante à das preposições. Após cada partícula, infere-se que há uma inflexão da voz, então as vírgulas são dispensáveis. Para acompanhar a modulação vocal, procura-se cortar o texto logo após uma partícula ou um verbo para construir as linhas. Assim sendo, a mancha textual resultante dessas quebras não segue um padrão, pois depende de quando aparecem, na sentença, os elementos citados.

Figura 82. Formatação do texto em balões nos quadrinhos japoneses

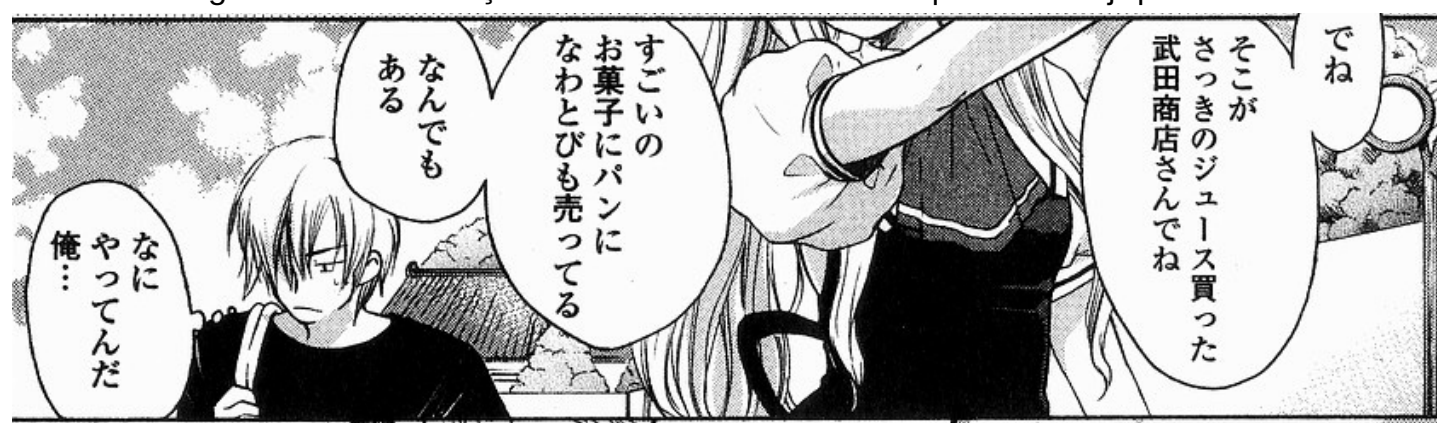

Fonte: KATSURA, 2005, p. 9

Um dos benefícios do sistema alfabético com caracteres de tamanhos regulares é que eles raramente se confundem. Já nas produções ocidentais, com a largura desigual dos caracteres, se o ajustamento do espaçamento entreletras (kerning) é descuidado, algumas letras acabam se juntando após impressas e dificultam o pronto reconhecimento. Klein (2010, p. 91) recomenda manter um espaço consistente entre as letras, com um pouco a mais para pontuação e o $i$ sem serifas. Este último, por ser um simples traço vertical, tende a se juntar com letras mais próximas. Devido a isso, tornou-se consenso entre os quadrinistas extinguir o uso de algumas palavras específicias que podem levar à sentidos ambíguos, como "clint" e "flick" ${ }^{24}$. Em letras maiúsculas, as letras / e $i$ mesclam-se parecendo a letra $u$, o que faz com que os termos mencionados virem "cunt" e "fuck", sinônimos informais para vagina e cópula.

Também é preciso prevenir que o texto seja distinguível quando visto à distância. Quando os super-heróis voltaram à proeminência na Era de Prata, o número de títulos desse gênero decolou e como o Superman da DC continuava sendo célebre, Stan Lee ficou preocupado com a logotipia de Spider-Man, nova criação da Marvel. Ambos começavam com "S" e vestiam vermelho e azul, por conseguinte, as capas poderiam ser confundidas pelos compradores. A saída encontrada por Lee reflete hoje como um diferencial do Homem-Aranha: ele é o único entre os maiores super-heróis a ter um hífen no nome original. (Figura 83) 25

24 CRONIN, B. Comic Book Legends Revealed \#217. Disponível em: <http://goodcomics.comicbookresources.com/2009/07/23/comic-book-legends-revealed-217/>. Acesso em: nov. 2014.

25 A informação pode ser visualizada através da rede social Twitter, disponível em <https:// twitter.com/TheRealStanLee/status/9602088102>. Acesso em: nov. 2014. 
Figura 83. Justificativa de Stan Lee para o nome de Spider-Man, 2010

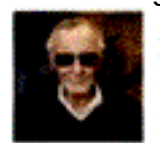

smilinstanlee Spidey's official name has a hyphen-"Spider-Man."

Know why? When I first dreamed him up I didn't want anyone

confusing him with Superman!

about 4 hours ago via web

Fonte: http://www.blastr.com/2013-7-16/little-known-sci-fi-fact-why-stan-lee-put-hyphen-spider-

-man (2013)

Assim como o espaçamento entre letras e entre palavras, o espaçamento entrelinha deve ser padronizado. Para otimizar o uso da área disponível, o espacejamento selecionado deve ser o menor possível que garanta a separação das linhas após a redução no momento da impressão. Campbell (2010) afirma que "o lettering em quadrinhos geralmente é mais apertado do que em outros tipos de composição tipográfica; contanto que haja algum espaço em branco entre as linhas, então isso é provavelmente o bastante." Já Piekos recomenda ${ }^{26}$ que o espaço seja de espessura suficiente para que duas linhas adjacentes de texto em negrito não colidam.

Algumas situações específicas pedem por divisões exatas em uma sentença que deixariam o quadro muito poluído caso fossem desenroladas em vários balões, então, assim como nos mangás, fornecer um espaçamento maior resolve. Campbell utilizou esse recurso para separar as estrofes de Romeo and Juliet, adaptação do clássico de Shakespeare pela Classical Comics. (Figura 84)

Figura 84. Espacejamento maior para demarcar estrofes em Romeo and Juliet

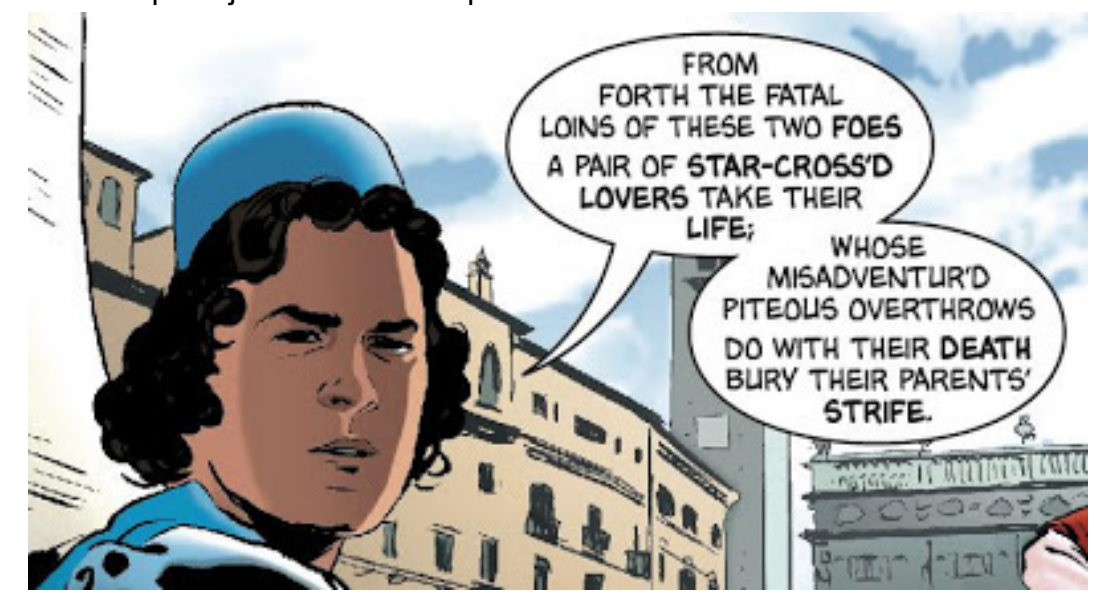

Fonte: http://clintflickerlettering.blogspot.com.br/ (2014)

Como apresentado na seção 3.3.1, o letreiramento digital permite que o uso de letras minúsculas tenha quase a mesma complexidade que o emprego de caixa alta. Quase, porque as minúsculas implicam existência de partes descendentes nas letras $g, p, q, j, y$ e, às vezes, $f$ e $z$. Ou seja, o espaço requerido entre as linhas é maior. Idiomas que possuem acentuação gráfica aumentam essa exigência para que não haja encontro entre possíveis acentos e a linha superior.

26 Learn lettering with Nate Piekos. Comics worth reading, jun. 2012.Disponível em: <http:// comicsworthreading.com/2012/06/09/learn-lettering-with-nate-piekos/>. Acesso em: out. 2014. 
A língua japonesa também expõe singularidades que ditam o espacejamento entrelinha. Sua escrita é característica por ser constituída de três alfabetos diferentes: dois silabários e um de ideogramas. Os primeiros, hiragana e katakana, diferem-se pelas formas diferentes para os mesmos sons e pelo uso. Enquanto o hiragana é empregado para palavras de origem japonesa, o katakana é usado para termos estrangeiros e onomatopeias.

Os kanjis, por outro lado, foram importados da escrita chinesa e representam ideias, significados. Diferente dos silabários, que contêm cerca de 50 caracteres cada um, os kanjis de uso geral são de dois a três mil, sendo ensinados durante todo o período escolar.

Excetuando os mangás de gênero infantil, os quais são inteiramente escritos em alfabetos de silabário, os kanjis são normalmente inseridos nos quadrinhos japoneses e, para abranger os estudantes em seu público-alvo, coloca-se uma espécie de legenda para os ideogramas. A legenda, chamada de furigana, representa a pronúncia literal do kanji em sílabas do hiragana. (Figura 85)

Figura 85. Escrita em hiragana, kanji e furigana para a mesma palavra, "mangá"

$\begin{array}{ccc}\text { Hiragana } & \text { Kanji } & \text { Kanji com furigana } \\ \text { ま } & \text { 漫 } & \text { 漫ん } \\ \text { ん } & \text { 画 } & \text { 画が } \\ \text { が } & & \end{array}$

Fonte: da autora

Dado que o furigana é disposto imediatamente próximo ao logograma de referência (Figura 86), o espaço vertical entre linhas deve prever seu encaixe.

Figura 86. Uso de kanji com furigana em mangá

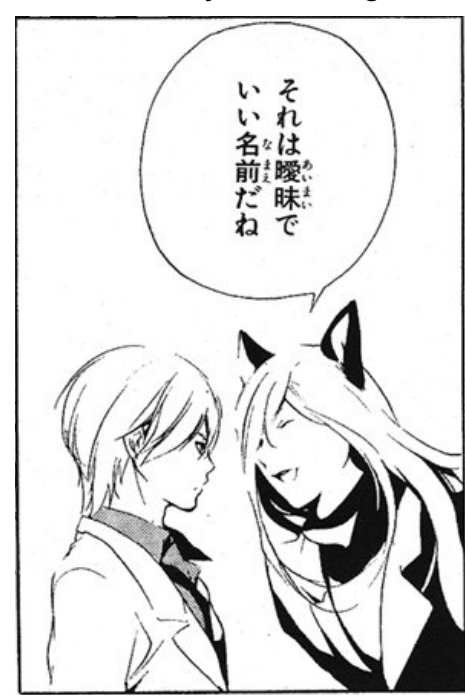

Fonte: KATAGIRI; NINOMIYA, 2009, p. 196 
Nos paratextos linguísticos, a inscrição em placas, jornais e outros deve respeitar a perspectiva e a natureza do material onde está inserida. Por exemplo, as letras diminuem conforme ficam mais distantes no cenário, o texto estampado em um traje acompanhará suas dobras do tecido, o que for refletido em um espelho deve ser invertido horizonalmente, textos entalhados ou chanfrados devem simular tridimensionalidade através de realces e sombras.

Para os demais tipos de texto em quadrinhos, como letreiros e títulos, não há regras exclusivas. O alinhamento depende de seus suportes, que são variáveis. Os espacejamentos, assim como em qualquer design de texto, devem prezar pela legibilidade e fluidez de leitura.

\subsubsection{Volume e entonação}

Nas histórias em quadrinhos, as palavras escritas desempenham função sonora na medida em que o leitor as recita mentalmente. Para que a transmissão auditiva ocorra de maneira eficiente de acordo com as intenções do produtor, a forma da letra empregada pode fornecer pistas para que a leitura apresente as nuances desejadas. É imprescindível que os tipos de formatação sejam padronizados em forma, tamanho e espessura de traço, a fim de que a variação da letra como modulação vocal seja nítida. Quando a mudança é perceptível, há um indicativo de que o som emitido é diferente do habitual.

Textos grandes e grossos chamam a atenção como um grito, assim como letras pequenas são discretas como um murmúrio. Letras tremidas indicam inconstância tonal, letras finas causam impressão de sons agudos, letras que pulam para fora do balão evocam desespero (Figura 87). Todas as propriedades visuais da formatação podem ser utilizadas a serviço da expressividade da história.

Figura 87. Grito pulando para fora do balão causam impacto de exaltação e angústia

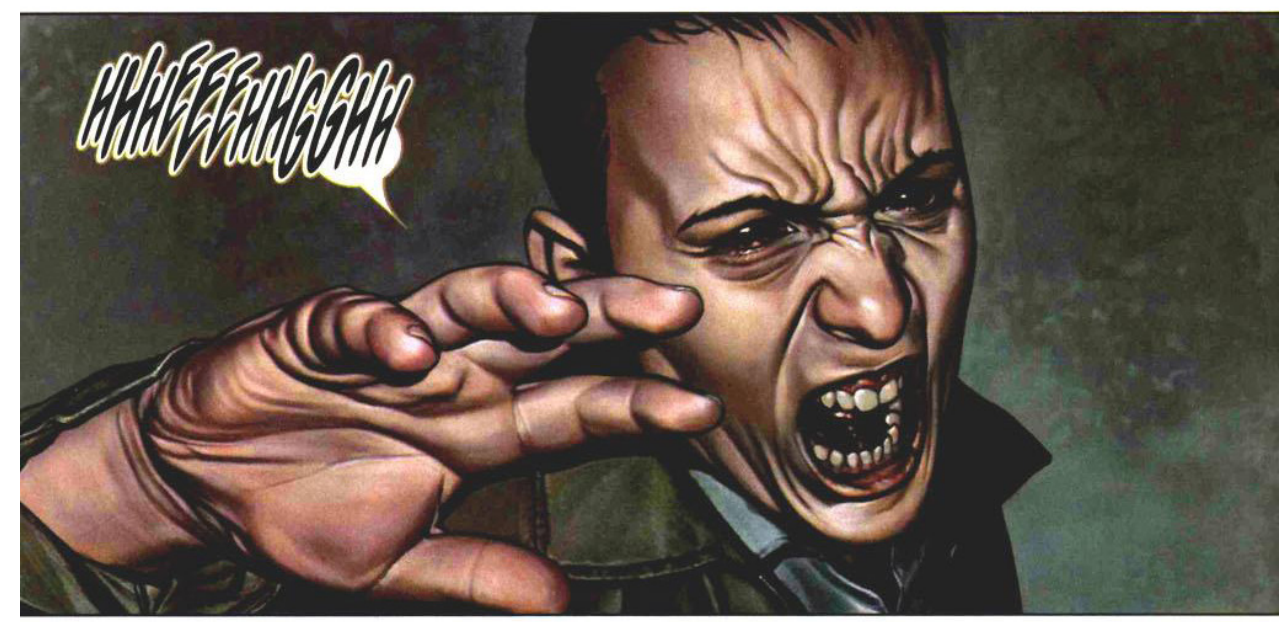

Fonte: ElLIS; Granov, 2005, p. 7 (letras por Randy Gentile) 
Eisner (2010, p. 164) lembra que o diálogo deve ser ouvido dentro da cabeça, e o uso de negrito para dar ênfase em determinadas palavras colabora em transmitir a dramatização da fala. Além de marcar a entonação (Lainé; Delzant, p. 18), o negrito mostra os detalhes mais importantes quando é feita uma leitura superficial, passando uma noção do conteúdo.

Embora seja uma prática frequente nas HQs estadunidenses, o negrito com essa finalidade é pouco adotado em outros países. Os quadrinhos asiáticos raramente mesclam espessuras de traço em um mesmo texto. Nikolavitch (apud Lainé; Delzant, 2010, p. 19), falando a respeito das bandes dessinées (quadrinhos franceses), considera que relevar termos através do negrito é "um insulto à inteligência do leitor", pois este consegue distinguir os pontos vitais do texto sem ajuda.

Já o itálico tem mais versatilidade de funções. É a opção-chave quando uma variação tonal é necessária, mas deseja-se fazer uma mudança gráfica sutil. Sussurros, canções, interjeições e ironia são comumente representados pelo itálico. O uso também é encontrado em monólogo interno, tanto em caixa narrativa quanto em balões de nuvem. Palavras estrangeiras, títulos de obras e vocalizações que não representam palavras também são trajados pelo itálico.

Figura 88. No letreiro, a interjeição de soluço, "hic", aparece em itálico

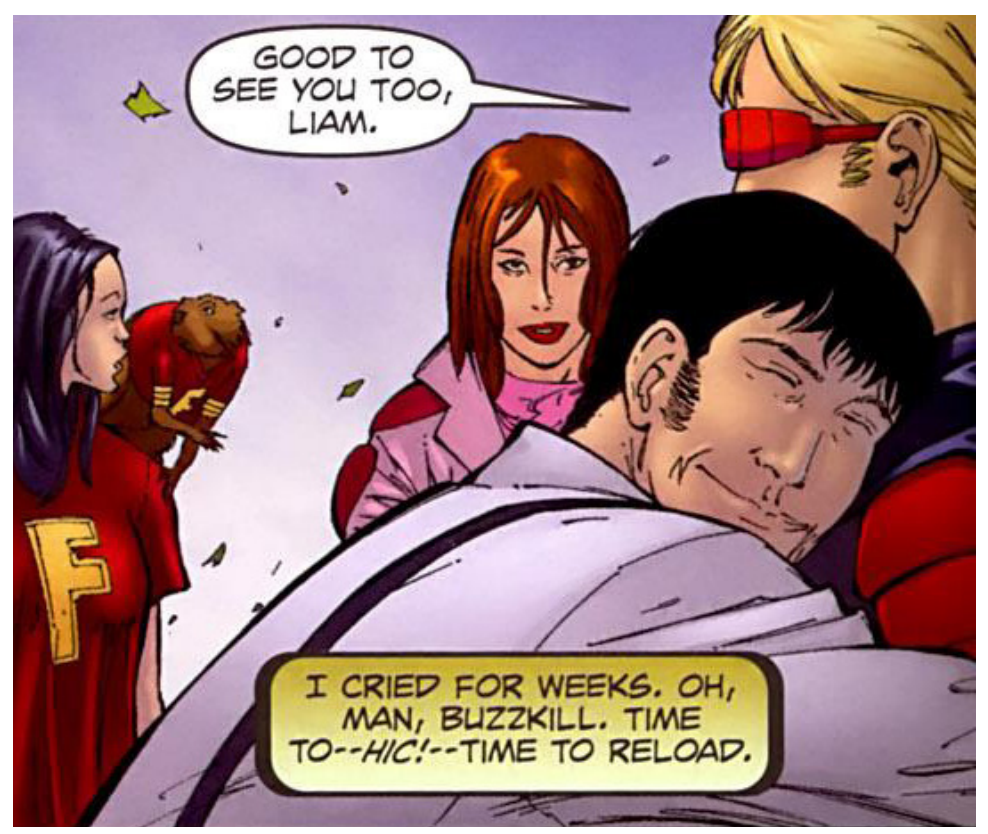

Fonte: Green; SteRbakov; MitchelL, 2008, p. 15 (letras por Troy Peteri) 


\subsubsection{Estilização}

Assim como os balões, o estilo das letras amplia a dimensão do personagem emitente (Eisner, 2010, p. 25). O letreiramento serve como ferramenta de dublagem e pode conferir vozes únicas quando necessário.

Sandman, escrito por Neil Gaiman e letreirado por Todd Klein, é uma série que constantemente demandava esse recurso, visto que é uma história repleta de entidades singulares. Em seu site ${ }^{27}$, Klein afirma que:

eu sempre digo que estilos especiais deveriam ser usados apenas quando há uma boa razão para isso. Mas nos excelentes roteiros de Neil, ele não parava de aparecer com boas razões.

(tradução da autora)

Na Figura 89, temos uma das primeiras aparições da personagem Delírio no livro. Gaiman já tinha em mente o jeito de falar da moça: uma voz cujo volume aumentasse e abaixasse, como algo entrando e saindo de foco. $O$ resultado foram letras desalinhadas mudando de tamanho da forma como a jovem muda de aparência. O colorista Steve Oliff acentuou a inconstância característica da personagem com balões coloridos. Coloridos como os cabelos de Delírio, coloridos como seus olhos desiguais.

Figura 89. Letreiramento realça a personalidade de Delírio

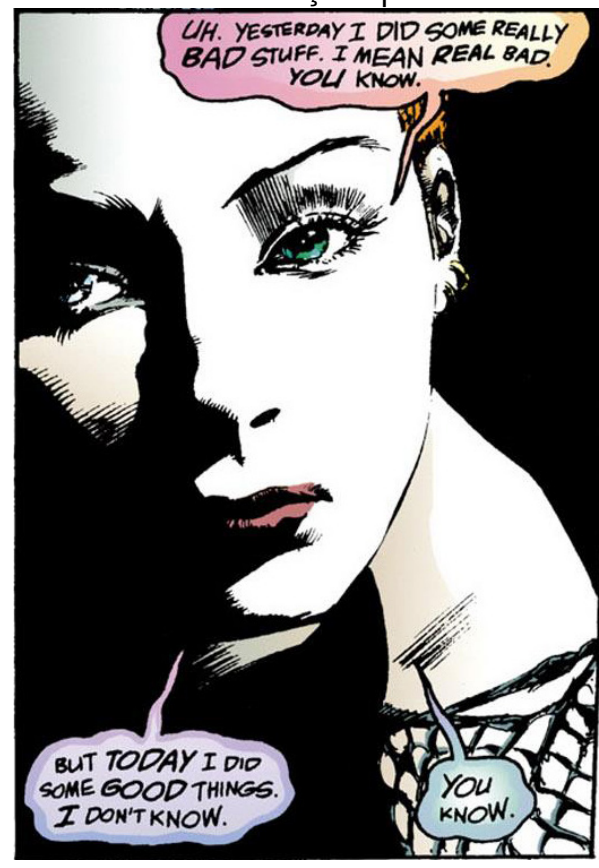

Fonte: GAIMAN, 2011, p. 20 (letras por Todd Klein)

$27 \quad$ Todd Klein on Neil Gaiman and Sandman. Disponível em: <http://kleinletters.com/NeilGaimanLettering.html>. Acesso em: jul. 2013. 
O letreiramento também pode se integrar ao caráter da personagem ressaltando outras essências. Por exemplo, a equipe Comicraft atendeu ao pedido de Scott Lobdell de criar estilos condizentes com os poderes de cada membro de Fantastic Four, ao desenvolver letras ásperas para o Coisa, balões flamejantes com texto vermelho para o Tocha Humana e balões transparentes para a mulher invisível (Roshell; Starkings, 2003, p. 28).

O Homem de Ferro também ganhou letras novas do letreirista Randy Gentile (Figura 90). Quando trajando sua armadura, o personagem ganha voz robótica através das letras quadradas, as quais lembram aquelas exibidas na tela dos relógios digitais e de outros aparelhos eletrônicos.

Figura 90. Fonte de tema tecnológico usada para a fala do Homem de Ferro
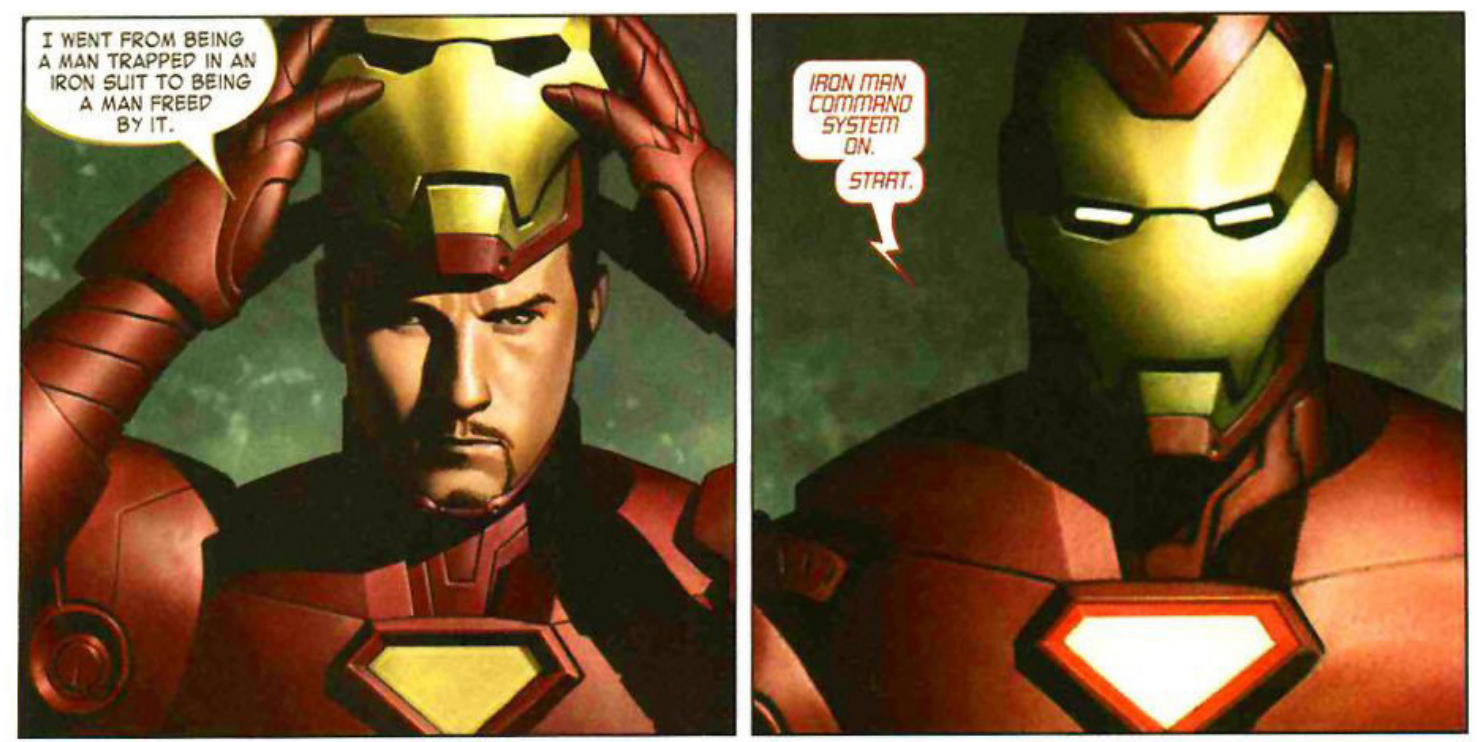

Fonte: ElLIS; Granov, 2005, p. 25 (letras por Randy Gentile)

A forma da letra também funciona como referência temporal. Um detalhe histórico que os quadrinistas Goscinny e Uderzo levaram em conta é que as aventuras de sua obra, Astérix, se passam antes da invenção da numeração indo-arábica, que ocorreu aproximadamente em 500 d.C. (Jean, 2002, p. 56) Portanto, os números são sempre retratados em algarismos romanos, os quais existem desde o século IV a. C. (Jean, 2002, p. 64) Por se tratar de um sistema de numeração pouco utilizado, os criadores previram que os leitores poderiam ter dificuldades em ler números maiores que dez, então estes possuem uma legenda em letreiro editorial no mesmo quadro.

Figura 91, observamos que os números possuem um estilo gráfico diferente, apresentando serifas, variação de espessura e formato mais retilíneo, remetendo à escrita romana antiga. 
Figura 91. Contagem em algarismos romanos em Astérix

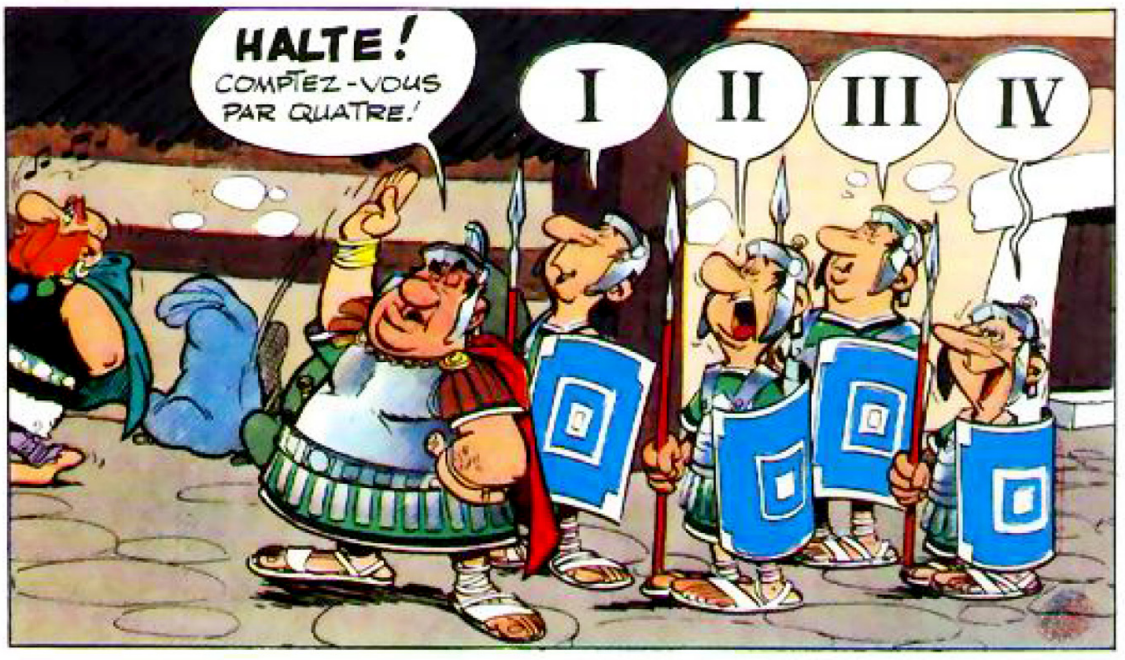

Fonte: GoscINNY; UdERZO, 1965, p. 45

No entanto, a diversidade de estilos mais conhecida de Goscinny e Uderzo é a que reflete as características culturais e idiomáticas de cada nação, ao definir os padrões em escrita de acordo com a grafia original do povo retratado. Os godos se expressam em escrita gótica, a qual reforça sua cultura germânica, enquanto os egípcios falam em hieróglifos e os gregos falam em letras retas, parecendo entalhadas, assim como as inscrições gregas antigas.

A ideia já havia sido explorada esporadicamente por outros autores. Como ilustra a Figura 92, Charles Schulz já havia feito, em 1953, o personagem Shroeder cantar em alemão por meio de letras góticas, remetendo ao caráter antigo germânico da sinfonia.

Figura 92. Shroeder cantando a Sinfonia $n^{\circ} 9$ de Beethoven, em letras góticas
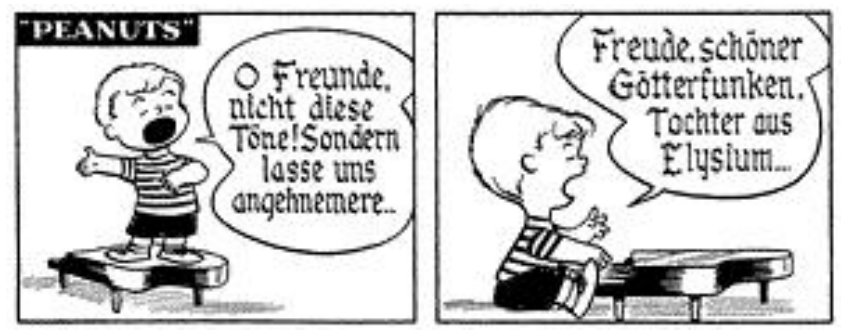

Fonte: http://peanuts.wikia.com/wiki/May_1953_comic_strips (2014)

Além da frequência de uso desse recurso, outra diferença é que Goscinny e Uderzo não escreviam o texto realmente em outra língua. A fala era em francês e o formato incomum da letra induzia o entendimento de ser um idioma incompreensível ou com sotaque para os protagonistas. Seguindo essa linha, o quadrinista pode ir além e retratar idiomas inexistentes, tais quais línguas de monstros e de alienígenas. Caso não haja intenção de que os leitores saibam o que está sendo dito, basta usar caracteres indecifráveis, como o faz Trondheim (Figura 93). 
Figura 93. Falas alienígenas incompreensíveis

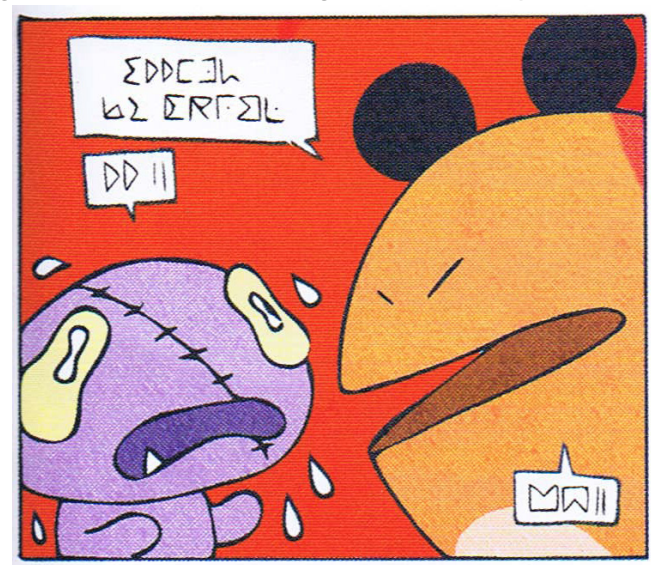

Fonte: TRONDHEIM, 2006, p. 19

Vale lembrar que o que se busca é um equilíbrio entre a riqueza dos resultados possíveis com a clareza do que é proposto. Quando o leitor é sobrecarregado de estilos variados, a aparição de um novo perde o efeito e os existentes vão deixando de ser especiais.

\subsubsection{O não-verbal}

Existem casos em que o som proferido é impossível de ser expressado por meio do nosso vocabuláro. Para verbalizar gemidos, suspiros ou até o barulho de engolir seco, houve uma aproximação fonética que permitisse o entendimento do som ao pronunciarmos as palavras mentalmente. "Hum", "ufa" e "gulp" são exemplos interjeições que se tornaram comuns para esse fim.

Figura 94. Formas de inserir interjeições em balões de fala

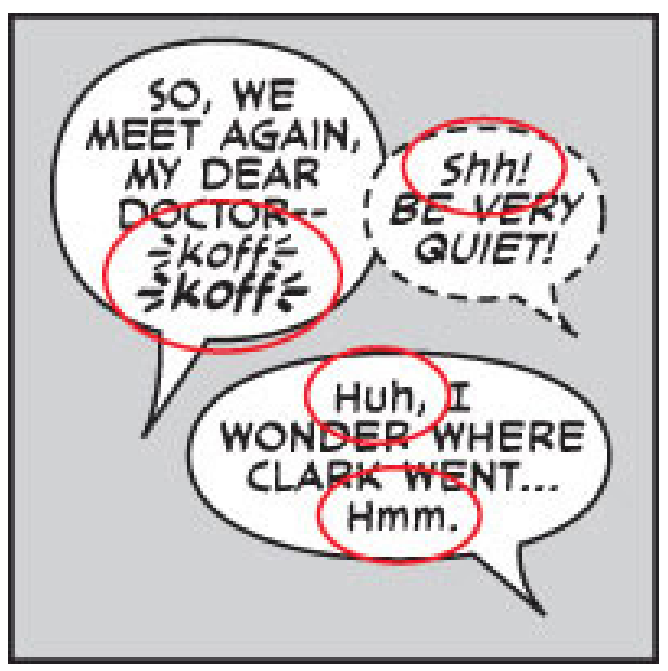

Fonte: https://comicbookguide.wordpress.com/2011/12/29/comic-book-syntax/ (2014) 
Ao inserir as interjeições dentro de balões, faz-se uma diferenciação entre elas e a fala normal. O uso do itálico, como dito anteriormente, é uma das saídas. $\mathrm{Na}$ Figura 94, podemos ver outras soluções. O balão à esquerda usa as chamadas marcas de respiro ${ }^{28}$ para distinguir a tosse. Já o balão na parte inferior utiliza as letras minúsculas em oposição à fala toda em caixa alta.

Nem sempre esse desafio precisa ser resolvido com palavras. Há situações em que figuras são mais expressivas que os vocábulos ou que representam melhor a intenção do autor. Em vez de tentar transcrever o som de um assobio, pode ser colocada uma nota musical dentro do balão. Da mesma maneira, um suspiro apaixonado pode ser representado por corações e a dúvida pode aparecer em forma de um ponto de interrogação.

Na Figura 95, de 1954, Schulz leva a ideia ao campo do humor, mostrando a interferência estática transmitida pelo rádio de Charlie Brown por meio de desenhos abstratos, no lugar de onomatopeias.

Figura 95. Interferência estática representada por arte abstrata
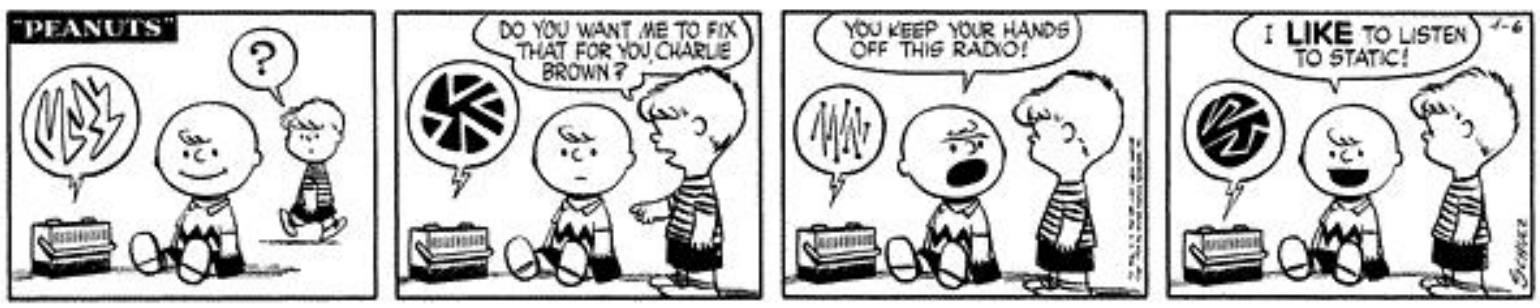

Fonte: http://peanutsroasted.blogspot.com.br/2011/06/ (2014)

O linguajar profano é um caso à parte. Embora seja possível escrevê-lo em palavras, o xingamento é muitas vezes representado por grafismos para diminuir o impacto da agressão verbal. Símbolos como crânios e cobras podem ser desenhados, enquanto outros podem ser digitados, como “\#@\&\$!". Para maior comodidade, existem fontes desenvolvidas exclusivamente com figuras desse sentido.

Figura 96. Alguns caracteres da fonte Curses, por Vic Fieger

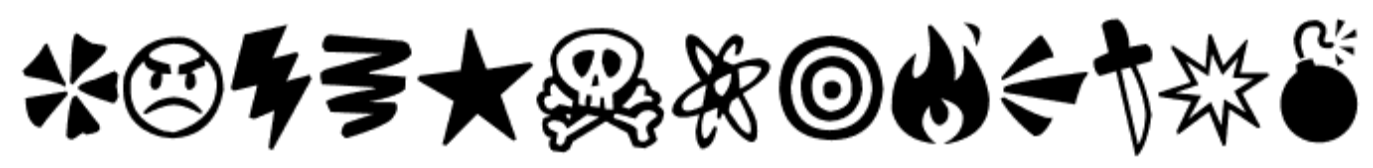

Fonte: http://dafont.com/curses.font (2015)

Em 1980, Walker (2000) publicou seu livro The Lexicon of Comicana, onde componentes variados das histórias em quadrinhos eram nomeados e classificados. Segundo ele, jarns compreendem todas as variações de espiral, quimps são ícones

$28 \quad$ Definida por três pequenos traços, a marca de respiro possui outras nomenclaturas informais como fireflies (vagalumes), cat's whiskers (bigodes de gato), crow's feet (pés de corvo) e roachlegs (patas de barata). 
astronômicos, nittles são todo tipo de estrelas e grawlixes são garranchos. (Figura 97) Embora nenhuma das definições seja oficial, o termo grawlix foi adotado para abranger todo o conjunto de símbolos ofensivos ${ }^{29}$.

Figura 97. Classificação de profanidades

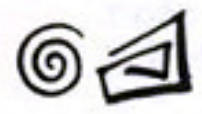

Jarns

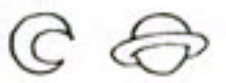

Quimps

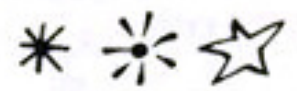

Nittles

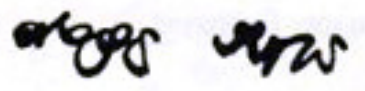

Grawlixes

Fonte: WALKER, 2000

A finalidade dos grawlixes é amenizar as palavras pesadas, portanto, são utilizadas principalmente em histórias para o público infanto-juvenil. Contudo, para acrescentar humor, obras para audiências mais maduras também podem se valer de censura, como se pode verificar na figura seguinte. Em vez de usar grafismos, o xingamento é coberto por um bipe de censura, imitando aquele escutado em rádio e em mídias televisivas.

Figura 98. Xingamento censurado por bipe

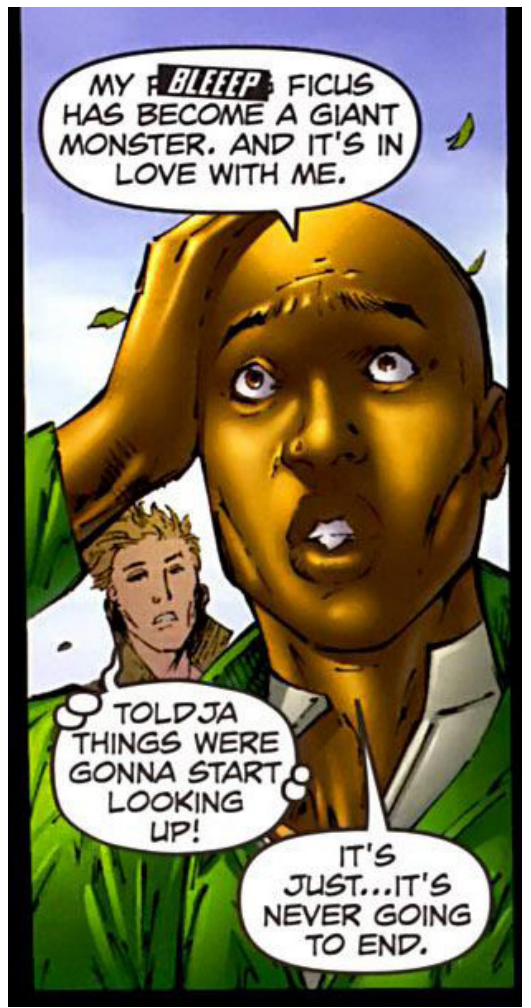

Fonte: Green; Sterbakov; Mitchell, 2008, p. 5 (letras por Troy Peteri)

$29 \quad$ Ao procurar pela palavra "grawlix" em um site de busca, houve retorno de 54.200 resultados. A maioria apresentava definições de dicionários e alguns se exprimiam como nomes de programas, bandas, entre outros. Todos os usos se baseavam no significado de "símbolos tipográficos usados para representar obscenidade ou palavrões". 


\subsubsection{Onomatopeias}

As onomatopeias são tentativas fonéticas de representar sons e barulhos naturais por meio do sistema escrito, adotadas como solução para incorporar áudio à dimensão visual. Trata-se de um recurso que reforça a capacidade comunicativa do texto (Lima, 2010, p. 2) e enriquece o ambiente em que se passa a trama, assim como os sons de fundo e os efeitos sonoros em um filme. Com isso, a história ganha mais dinamismo e vivacidade.

Esses elementos variam entre as regiões, não existindo uma maneira exata de reproduzir graficamente o som. Existem, porém, os mais difundidos em cada local, como o "au au" no Brasil, que é conhecido como "woof woof" nos países de língua inglesa e "wan wan" no Japão.

Como visto no capítulo anterior, a popularidade dos quadrinhos de super-heróis propagou as onomatopeias estadunidenses, as quais se originaram dos verbos em inglês. Algumas universalizadas são "crash", que veio de espatifar, e "sniff", de fungar. (idem, p.2; Luyten, 2001-2002, p. 180)

Nas histórias em quadrinhos, as onomatopeias recebem um tratamento privilegiado (Gasca apud Luyten, 2001-2002, p. 4), graças à dimensão plástica que aufere tamanhos, estilos e texturas condizentes com cada ruído. Diferentemente dos pensamentos e diálogos, as onomatopeias dispensam suporte e muitas vezes até extravasam as bordas dos quadros.

O tamanho do efeito visual define a intensidade do som representado. (Lainé; Delzant, 2010, p. 39) Quanto maior e mais grossa a letra, maior o impacto causado por sua aparição e, portanto, mais ensurdecedor parece. Quanto menor e mais fina, mais discreto é o ruído. Também é o tamanho que colabora para transmitir noção de profundidade da cena, colocando os barulhos mais distantes menores que os mais próximos. Dessa mesma forma, o som de um carro se distanciando vai diminuindo conforme o veículo se movimenta.

Figura 99. A perspectiva da onomatopeia colabora para dar profundidade ao ambiente.

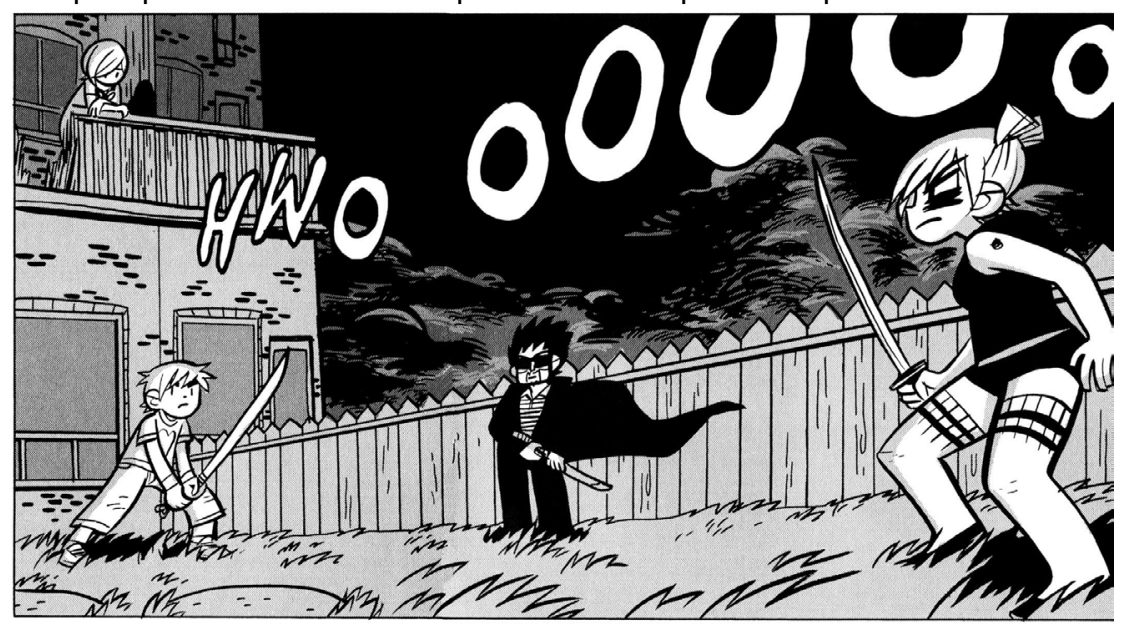

Fonte: O’MALLEY, 2007, p. 179 
Como no exemplo do carro, a disposição das letras pode sugerir deslocamento. Na tirinha abaixo, desenhada por Jim Davis em 1978, o zumbido da mosca revela seu trajeto, como se imprimisse letras no ar por onde passasse. Com apenas um quadro estático, o leitor pode visualizar mentalmente o inseto voando pelo caminho descrito, acompanhado pelo zunido incessante.

Figura 100. Disposição das letras podem reforçar a ideia de movimento.
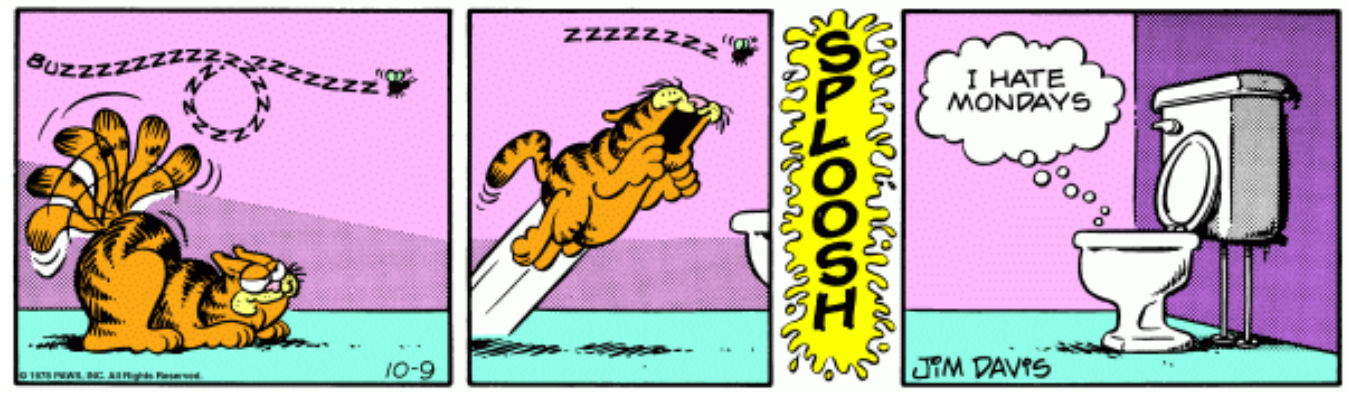

Fonte: http://tirinhastraduzidasdogarfield.blogspot.com.br/ (2014)

O desenho da letra e os adornos que acompanham a onomatopeia possuem potencial para ressaltar ou revelar a origem do barulho. O "Sploosh" da tira aparece sobre uma imagem aquosa, insinuando que ocorreu um evento onde líquido é espirrado. Esse presságio é confirmado no último quadro, onde o gato Garfield se encontra no vaso sanitário. Outros modelos bastante usados são o "smack" junto com o desenho de uma boca, o "crash" acompanhado de cacos de vidro e a música do ambiente rodeada por notas musicais. Na Figura 101, há um exemplo mórbido em que a onomatopeia "Crak" é desenhada com ossos quebrados, ficando clara a proveniência do som sem se revelar a cena.

Figura 101. Desenho do efeito sonoro salienta a ideia de fratura.

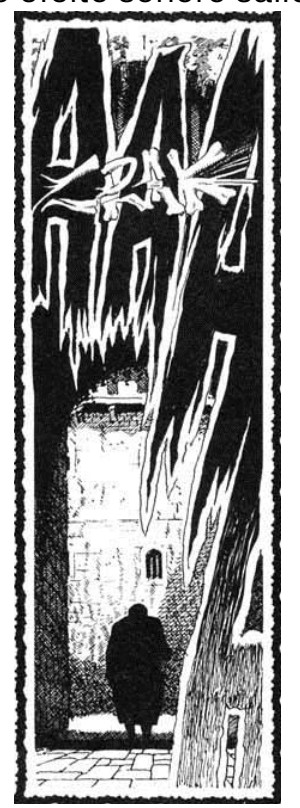

Fonte: Sim, 1990, p. 15 
Por não estarem limitadas a um suporte nem necessitarem de um padrão, as onomatopeias possuem diagramação mais livre que os demais componentes textuais das HQs. O estilo da letra pode variar, de modo a assumir o formato mais adequado para cada caso. Segundo Lee (2010, p. 173), os efeitos sonoros são mais divertidos de se trabalhar, e é onde os letreiristas mostram seu lado criativo. No entanto, não se pode esquecer que cada história tem sua própria aparência, definida pela arte que a compõe, e o lettering deve complementá-la. Ambos, figura e texto, devem ser coerentes um com o outro.

Quando as etapas são feitas por pessoas diferentes, como em muitos títulos dos Estados Unidos, cabe ao letreirista analisar a ilustração para que sua parte mantenha a uniformidade da obra. Como o profissional tem que lidar com uma equipe e, portato, com diferentes formas de pensar, esse método de trabalho apresenta ainda alguns outros desafios. Roshell \& Starkings (2003, p. 20) contam que os escritores tendem a exagerar as onomatopeias nos scripts para indicar que 0 barulho tem de ser bem sonoro, inserindo longas sequências de letras repetidas ("SSPPPLOOOOOSSSHHH!!!"). A dica é manter a palavra mais concisa e comunicar o volume desejado por meio do tamanho e do arranjo das letras. As repetições se tornam prolixas quando o próprio efeito visual já transmite a ideia de estrondo.

Se é o responsável pela ilustração e pelo letreiramento é o mesmo, ampliam-se as possibilidades de combinar o texto à ilustração. Na Figura 102, as duas linguagens se fundem em uma mesma arte. O efeito sonoro, "Sploosh", surge na submersão do casal, em meio à espuma e às ondas do rio.

Figura 102. União de ilustração e onomatopeia.

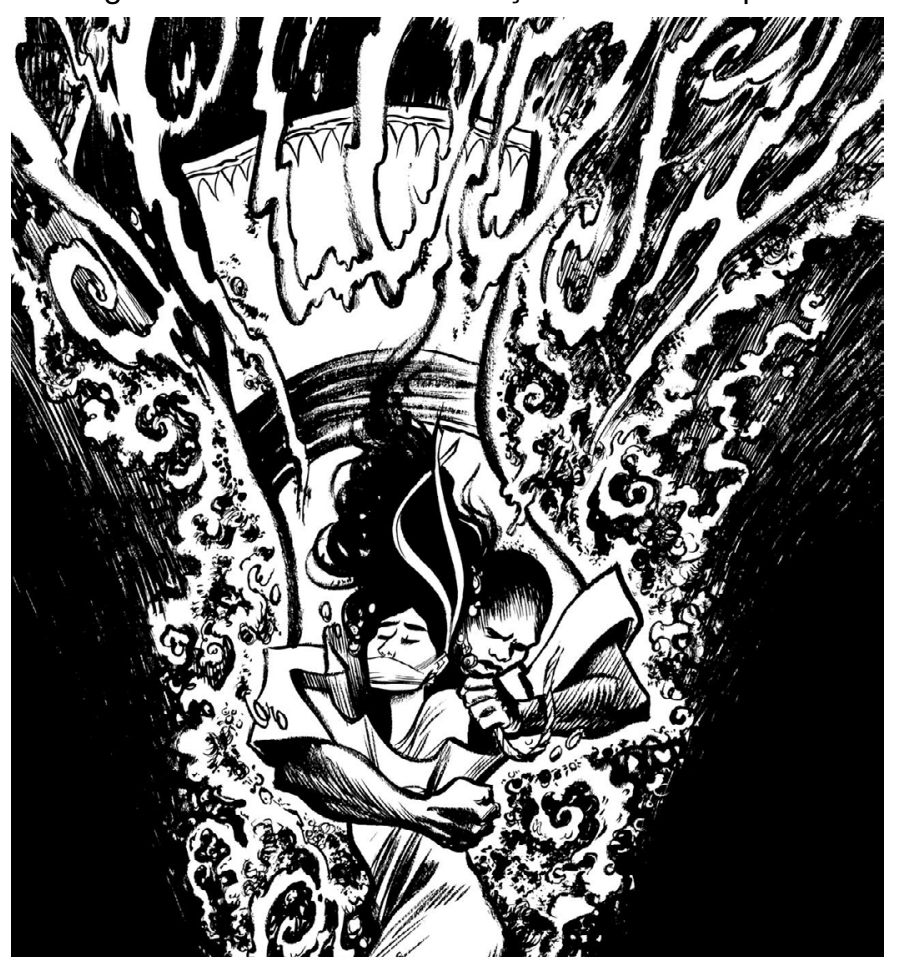

Fonte: THOMPSON, 2011, p. 443 
No Japão, é comum os mangakás contratarem assistentes, mas eles continuam sendo os encarregados pelos efeitos sonoros. $O$ tratamento que os quadrinistas realizam nesses efeitos faz com que o texto realmente seja combinado à arte, de maneira que torna-se difícil distinguir os caracteres para aqueles que não são acostumados com a leitura japonesa. (Luyten, 2001-2002, p. 181)

As onomatopeias nipônicas são escritas no alfabeto katakana, que é um silabário assim como o hiragana, com a diferença de que é usado principalmente para palavras estrangeiras. Pode parecer uma medida segregativa, no entanto, ao invés de os termos onomatopaicos serem marginalizados para uso exclusivo em quadrinhos, eles são na verdade incorporados ao vocabulário cotidiano e consistem em "um universo à parte dentro do idioma" (idem, p. 180).

Figura 103. Harmonia entre onomatopeia e ilustração em mangá.

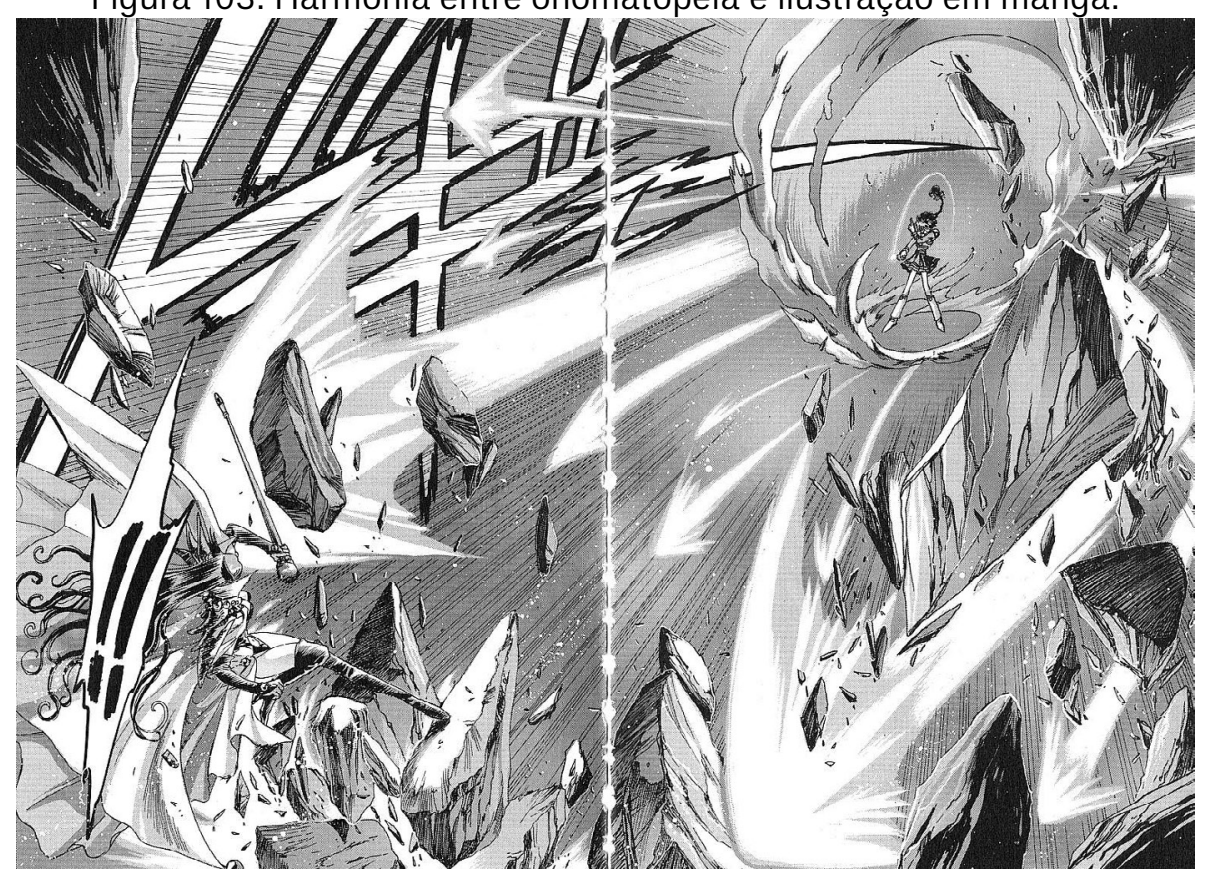

Fonte: CLAMP, 1994, p. 58-59

A união harmônica entre efeito sonoro e imagem pode interagir com outros elementos das HQs, gerando resultados inovadores. No sexto volume de Scott Pilgrim, o autor O'Malley dispôs propositalmente o ruído de um liquidificador sobre o balão de fala de Scott, ou seja, os leitores não conseguem ler o que ele diz por causa das onomatopeias, assim como o colega do protagonista não consegue escutá-lo devido ao alvoroço do aparelho.

Já o quadrinista Frank Miller, em sua obra Sin City, ampliou a dimensão do estampido dos disparos de uma arma e transformou-os nos próprios quadros. (Figura 104) Cada quadro é um momento singular, cada um se inicia com um tiro e cada um mostra uma cena diferente, que dura o tempo de se proferir a narração contida em cada "Blam!". 
Figura 104. Quadros delimitados pela forma de onomatopeia

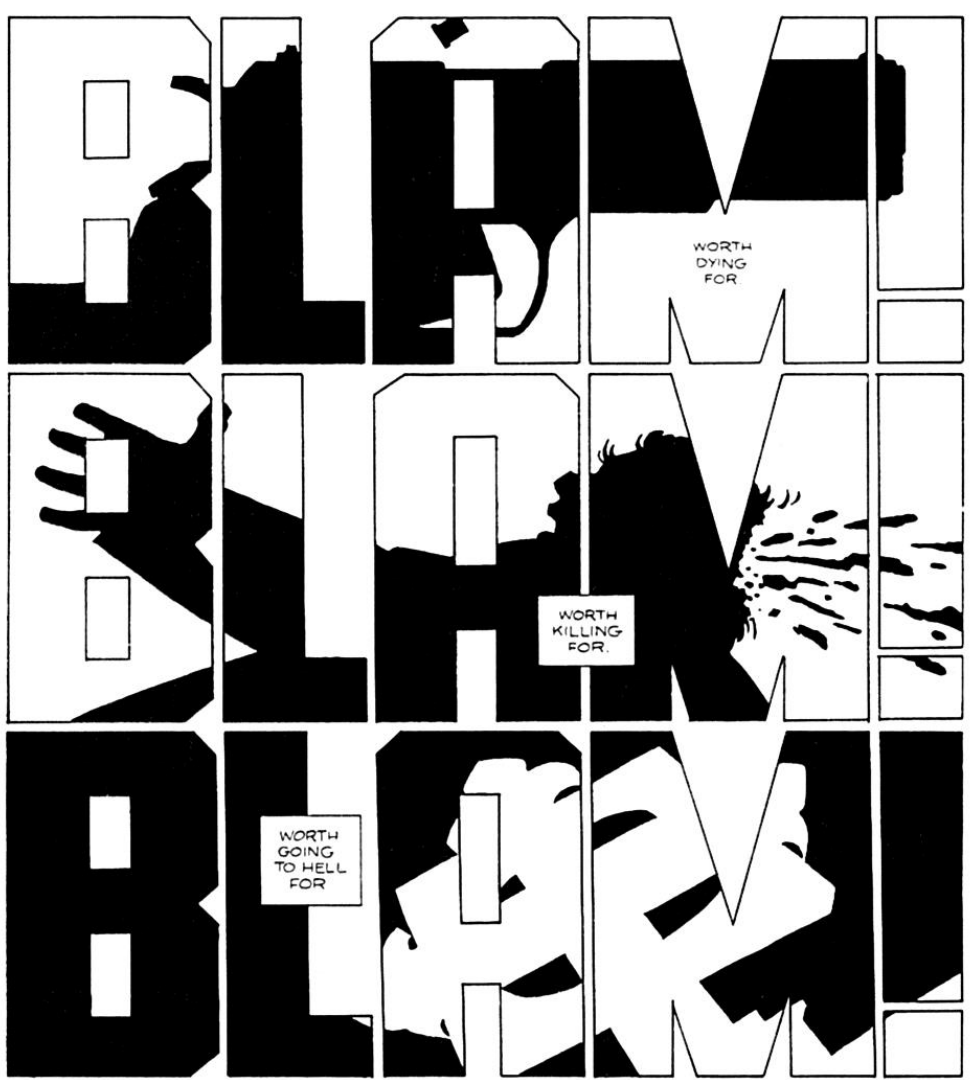

Fonte: Miller, 1991, p. 8

Dave Sim também explora variadas aplicações das onomatopeias em sua obra, Cerebus. No volume 291, lançado em 2003, o protagonista Cerebus começa a escrever um livro com tamanho fervor que o barulho de sua pena riscando o papel ("sktch sktch sktch") se torna plano de fundo em alguns quadros e passa até a emoldurar algumas páginas.

A metalinguagem é outro recurso utilizado pelo autor. No volume seguinte, Cerebus está inconsolável por seu filho, Shep-Shep, lamuriando-se dentro de sua casa, quando a chuva começa a cair. Os pingos, "thunt thunt", começam a bater na janela. Em uma das cenas representando esse evento, a própria explosão da gota contra o vidro forma a letra $U$ de sua onomatopeia. O personagem se revolta porque pediu a Deus por seu filho de volta e é isso que recebe: chuva. Enquanto os pensamentos indignados de sua mente vão se calando, o barulho vai se tornando mais intenso, a ponto de os efeitos sonoros serem mais visíveis que o gotejar em si. Conforme as páginas passam, o som parece mais insistente e mais manifesto no ambiente, dado que as onomatopeias se tornam numerosas, e parece mais pesado e mais enervante, pois seu tamanho aumenta.

O "thunt thunt" ganha tanta importância em sua presença que, quando aparece a sombra da janela sobre o assoalho, as sombras das onomatopeias também são contempladas na imagem. (Figura 105) 
Figura 105. Barulho da chuva se manifesta com tanta persistência que possui até sombra.
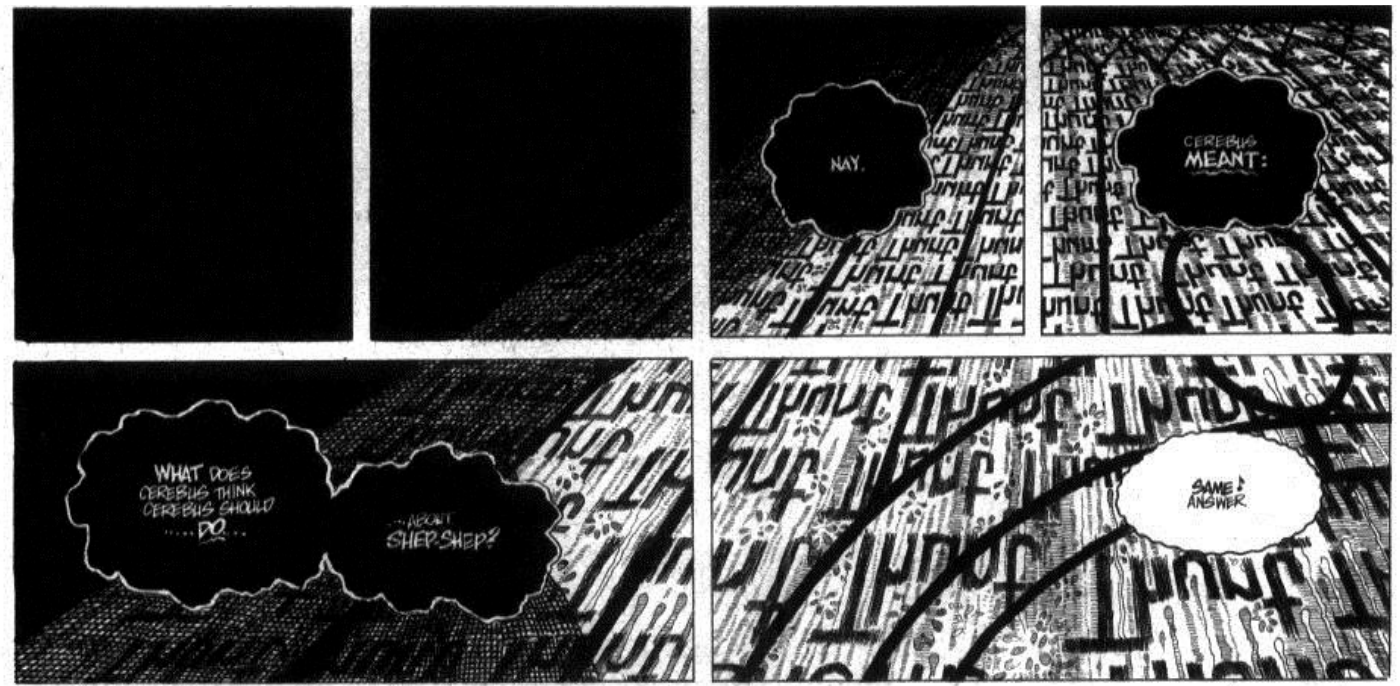

Fonte: Sim, 1990, p. 13

\subsubsection{Titulos}

O logo de cada título deve ser representativo quanto ao tema da história. Klein (2004, p. 96) considera esse elemento como um espaço de inserção de impacto e de mostra de criatividade. Roshell e Starkings (2003, p. 37) instruem a reproduzir o gênero da obra, conforme o estilo de arte e a natureza que o nome por si só sugere. Portanto, é preciso primeiro compreender o significado das palavras que compõem o título e a intenção da trama.

A obra The Incredible Hulk, criada por Stan Lee e Jack Kirby em 1962, teve seu título trajado em diversos designs no decorrer do tempo até hoje. Por estes se referirem a uma mesma série, alguns padrões são percebidos. As letras são frequentemente largas e grandes, de fácil alusão ao porte corpulento do protagonista quando transformado. O nome do personagem principal em perspectiva tornou-se um arquétipo das histórias de super-heróis e, de fato, existem versões de Hulk que seguiram o exemplo. Foi o caso da primeira capa publicada e da coleção The Rampaging Hulk, publicada entre 1977 e 1978, em que o a extensão de profundidade concedida foi bem generosa, causando a impressão de um título sólido e grosso, ou seja, robusto e resistente como a natureza do personagem homônimo. Para enfatizar a ideia de volume e peso, algumas versões foram texturizadas para parecerem de concreto (Figura 106) e outras, como a vigente de 1968 até o fim de The incredible Hulk em 1999, foram além e carregaram o título desenhado como se fosse construído em blocos de pedra. ${ }^{30}$

30 Todas as informações e exemplos foram retirados do estudo feito por Todd Klein em: $<$ http://kleinletters.com/Blog/logo-study-the-hulk-part-1/> e partes subsequentes da postagem. (Acesso em mar. 2015) 
Figura 106. Título em concreto, desenhado por Jim Steranko em 1968

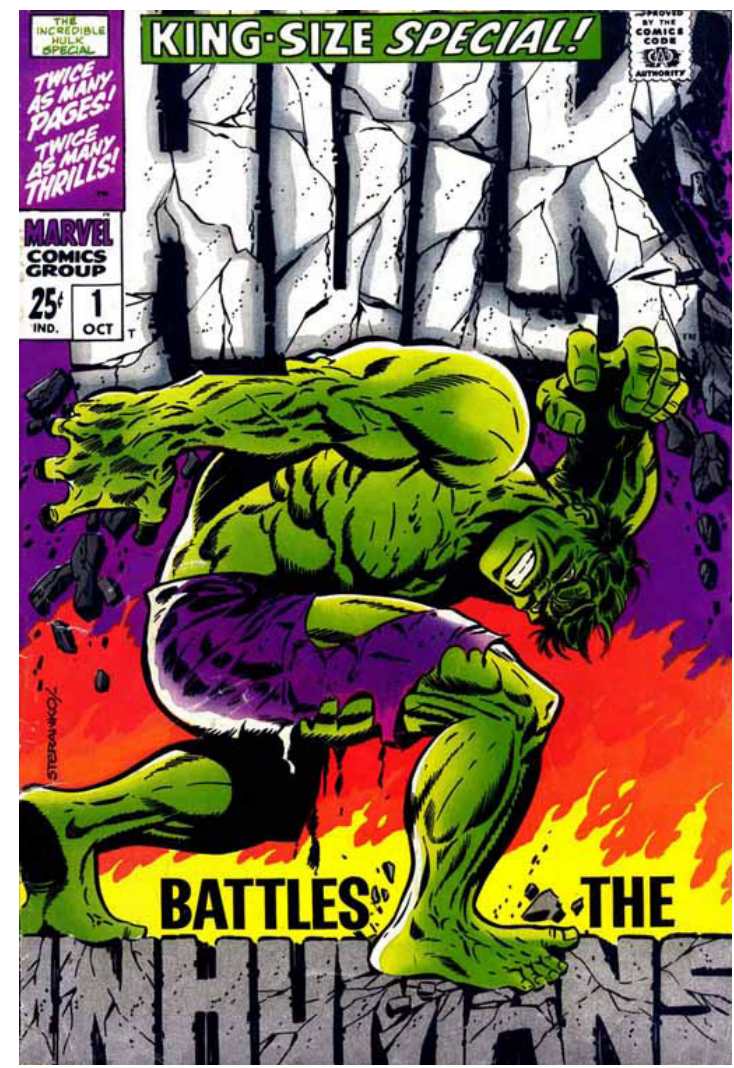

Fonte: http://kleinletters.com/Blog/logo-study-the-hulk-part-1/ (2014)

Roshell e Starkings (p. 29) também recomendam que o design seja vigoroso e imaginativo, porém, deve ser sempre fácil de ler. Klein (p. 106) sustenta a legibilidade e a força como características fundamentais de um bom logo e acrescenta adequação e originalidade à lista. Em muitos casos, esse design funciona como a marca permanente da série, sendo utilizada no marketing de produtos relacionados e facilmente reconhecida pelos fãs. Os títulos de mangás são geralmente mantidos os mesmos durante toda a sequência de publicações. Tomemos como exemplo a obra One Piece, iniciada em 1997 por Eichiiro Oda e que bateu recorde de vendas de revistas japonesas. O logo (Figura 107) se manteve inalterado desde a primeira edição e é aplicado em camisetas, canecas, casacos, cadernos e outras mercadorias de interesse do público.

Figura 107. Design do título de One Piece.

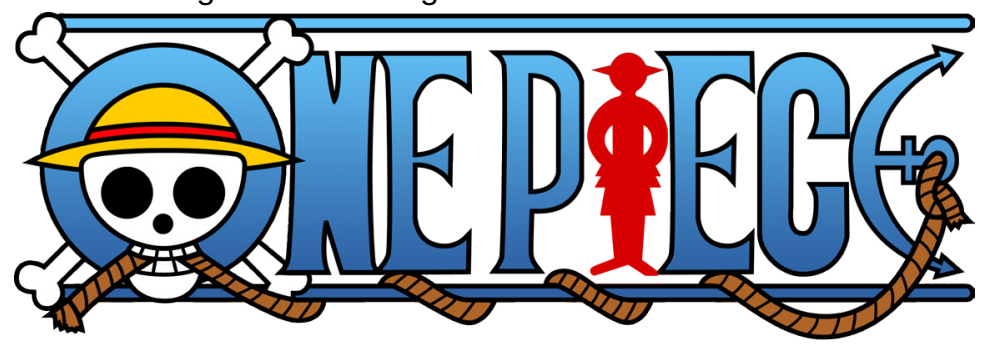

Fonte: http://www.ranklogos.com/ (2014) 
Existem HQs que são menos constantes e alteram o design de título. A mudança pode ser eventual e ser adotada apenas em uma edição especial. Também pode ser regular e ocorrer a cada arco de história, a cada reedição, a cada reinicialização do universo corrente (muito comum em trabalhos da Marvel e da DC), ou até mesmo a cada publicação. Como dito no capítulo 2, Will Eisner trazia um novo logo na página de abertura de cada episódio de The Spirit. Jim Davis adotou uma metodologia similar e, a cada tira dominical, o nome de Garfield aparece escrito de uma maneira inédita no primeiro quadro.

Figura 108. Diferentes logos para Garfield, por Jim Davis.
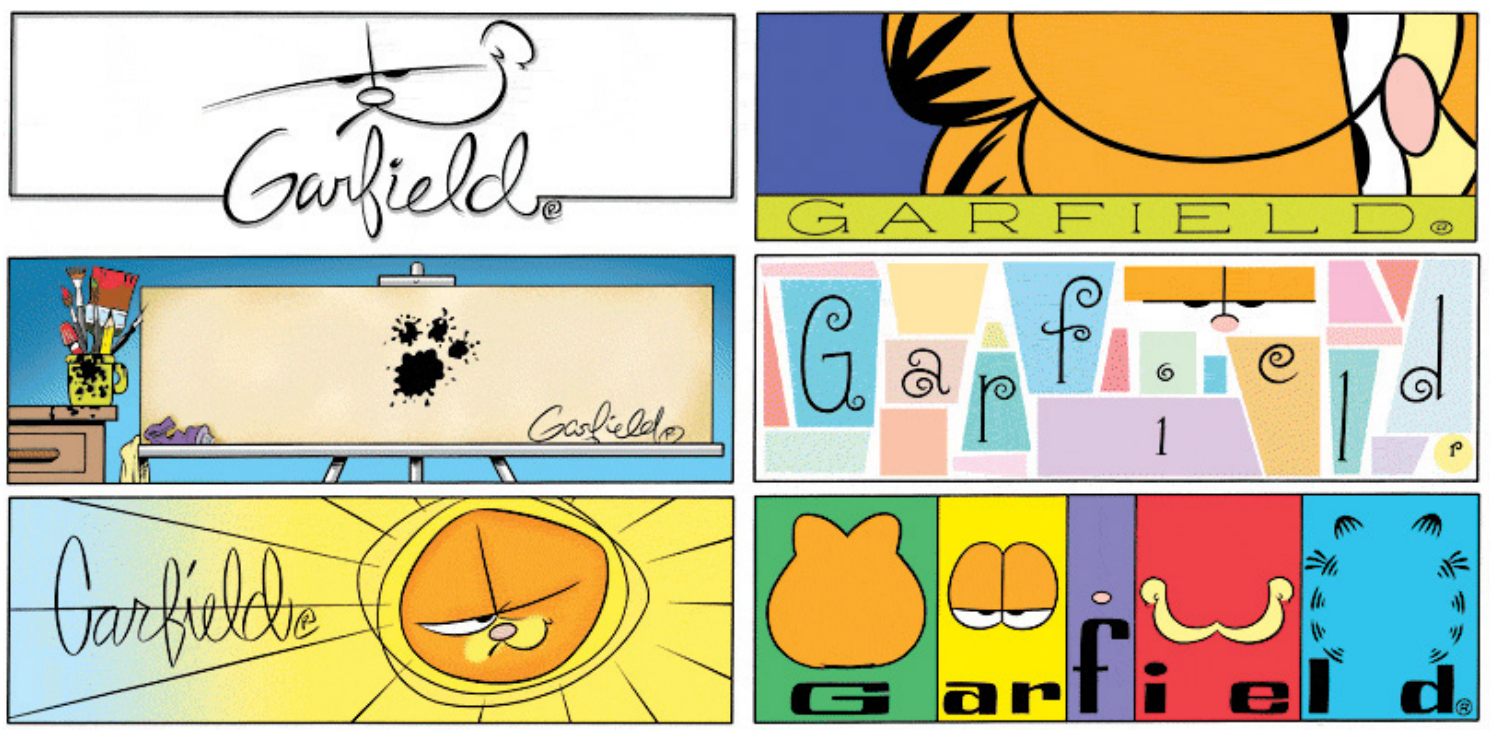

Fonte: tiras dominicais variadas de 2007

Da mesma forma que a diagramação dos textos dentro da história obedece alguns fundamentos do design gráfico, o design do título respeita alguns princípios da concepção de identidade visual, devendo ressaltar a essência da obra e ser evocativo. As histórias em quadrinhos, no entanto, são uma mídia especifica que desenvolveu singularidades para maior exploração da combinação entre texto e imagem. Suas próprias convenções são repletas de variáveis e mantêm abertura a novas experimentações, provando que o letreiramento está longe de ser um sistema rígido. 

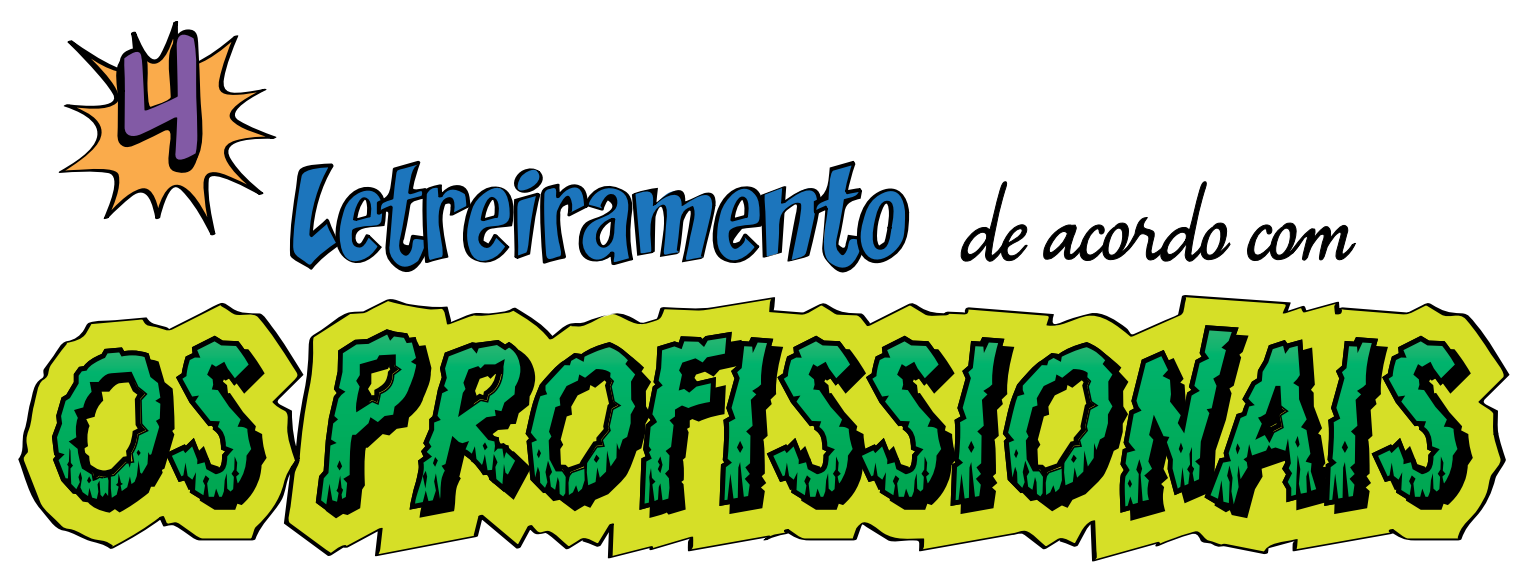

Gom cerca de 75 anos de existência, a profissão do letreirista é relativamente recente. Por isso e por ser um cargo ainda pouco conhecido, em contraste às etapas de roteiro e ilustração, o tratamento textual possui publicações escassas a respeito, dificultando a obtenção de informações detalhadas sobre a profissão. Para preencher essa lacuna, letreiristas e outros responsáveis pela criação de HQs foram contactados e responderam algumas questões sobre sua comunicação com os demais atuantes do processo, os aspectos considerados favoráveis e os obstruintes do letreiramento, entre outros pontos relacionados ao ofício. Neste capítulo, suas respostas são apresentadas junto a uma breve descrição de cada profissional participante.

Apesar de existirem obras detalhadas referentes ao letreiramento, como os livros de Roshell e Starkings (2003), Klein (2004), e Lainé e Delzant (2010), informações relacionadas à profissão do letreirista são raras nas publicações. É possível encontrar relatos nas páginas virtuais de letreiristas e em entrevistas concedidas sites voltados para quadrinhos. Como os endereços de e-mail dos profissionais estavam disponíveis para contato, alguns foram selecionados segundo relevância para a pesquisa e foi feita uma solicitação para que respondessem um questionário. Todos os contactados - seis letreiristas, um escritor e um editor-chefe - aceitaram colaborar com o projeto.

De cinco a dez questões abertas foram elaboradas para cada participante. A preparação das perguntas levou em consideração a função do respondente e seus trabalhos até o momento. As respostas foram analisadas individualmente e em conjunto, como será visto a seguir. 
Troy Peteri é letreirista chefe da Top Cow Productions e da Thrillbent, ambas as editoras situadas na Califórnia, e trabalha também para a Dynamite, de Nova Jérsei. Ainda no campo dos quadrinhos, escreveu Abattoir ao lado de Rob Levin para a editora Radical Studios, obra letreirada por ele mesmo.

Em resposta ao questionário enviado (Apêndice A), Troy conta que é formado em Design Gráfico e que lhe agradava a diagramação de texto durante o curso. Após se formar, conheceu o letreirista Rlchard Starkings em uma convenção, para quem mostrou seu portifólio, interessado em trabalhar como assistente de produção de quadrinhos. Logo, conseguiu uma vaga na Comicraft, a empresa de Starkings, onde aprendeu a exercer o ofício.

Troy já letreirou mais de 1100 publicações ${ }^{31}$, dentre as quais estão Amazing Spider-man, Green Hornet e Witchblade. Nos Estados Unidos, a produção nas HQs é normalmente quebrada em etapas e estas são trabalhadas por diferentes especialistas, sendo comum a variabilidade de equipe de uma série para outra, mesmo que seja roteirada por um mesmo escritor. Com seu grande volume de experiência, Troy já chegou a trabalhar com um mesmo profissional em títulos diferentes. Este foi o caso da relação de trabalho entre o letreirista e o escritor Ron Marz, com quem produziu diversas obras em uma relação de mútuo respeito e consonância das duas formas de trabalho ${ }^{32}$.

No entanto, a parceria entre um letreirista e um roteirista pode não ser tão fácil. Troy menciona, no mesmo artigo, que o maior aborrecimento enfrentado por ele ao lidar com novos escritores se refere à superestimação da quantidade de palavras que cabem em um quadro, onde a saída é frequentemente cobrir grandes áreas da arte com texto.

No questionário respondido, Troy afirma que não se comunica com o artista tanto quanto com o escritor e com o editor. Por outro lado, ele busca estabelecer um diálogo coeso entre o estilo empregado no letreiramento e o estilo aplicado na ilustração, como é possível conferir em Witchblade. Até o fim do arco Absolute Corruption (Figura 109), foram utilizados balões ovalados e a letra padrão de HQs. Já na edição 170, iniciando o arco Borne Again, o letreirista abriu mão das formas geométricas e recorreu a um formato mais orgânico para o balão, aparentando ser feito à mão livre (Figura 110). O desenho da letra também é trocado para um mais desalinhado, cujas alturas variam de caractere para caractere, com o estilo mais próximo de uma caligrafia informal.

31 Informação disponível em: <http://www.comicvine.com/troy-peteri/4040-42035/>. Acesso em: abr. 2015.

32 MARZ, R. Shelf Life: the Art of Lettering. Comic Book Resources, 26 jan. 2012. Disponível em: <http://www.comicbookresources.com/?page=article\&id=36639>. Acesso em: out. 2014. 
Figura 109. Estilo utilizado no arco Absolute Corruption, de Witchblade
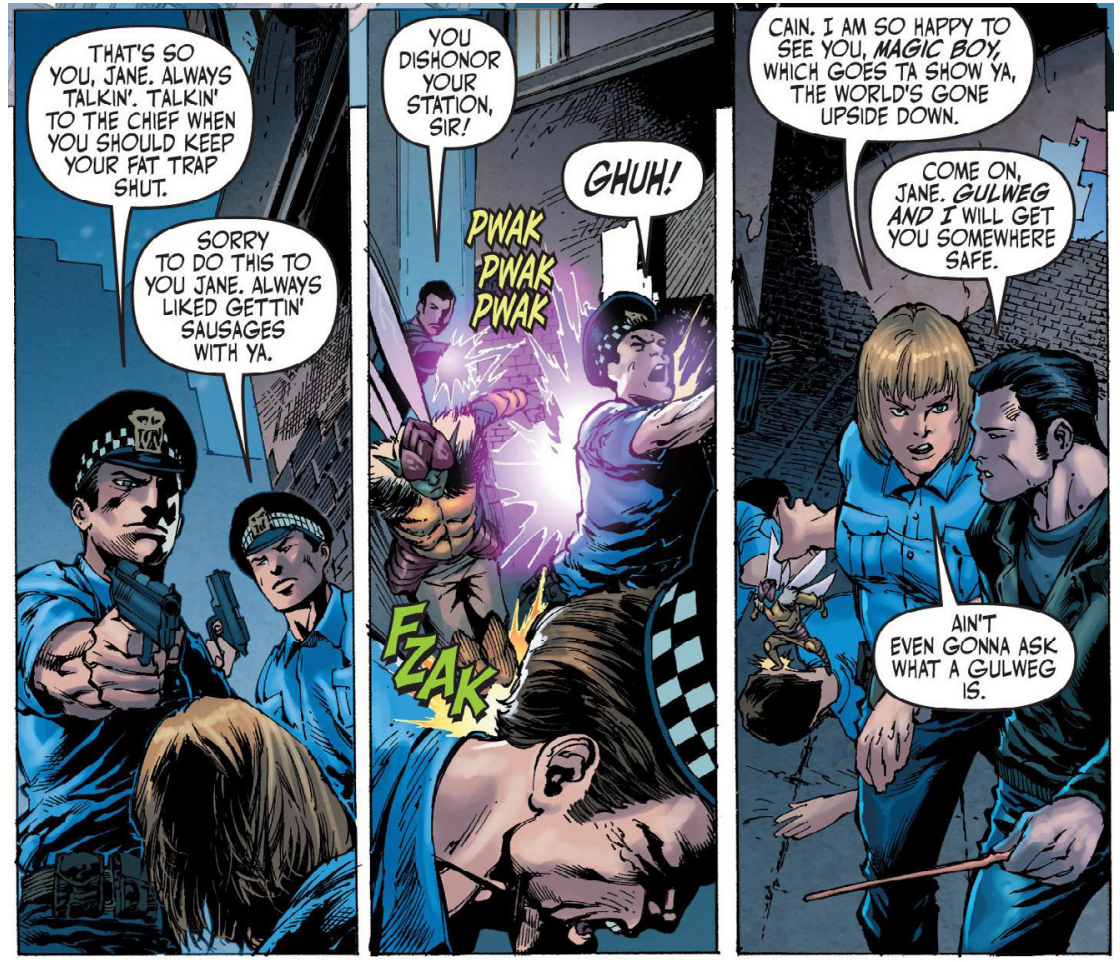

Fonte: Seeley, 2013, p. 5 (letreiramento por Troy Peteri)

Figura 110. Estilo utilizado no arco Borne Again, de Witchblade

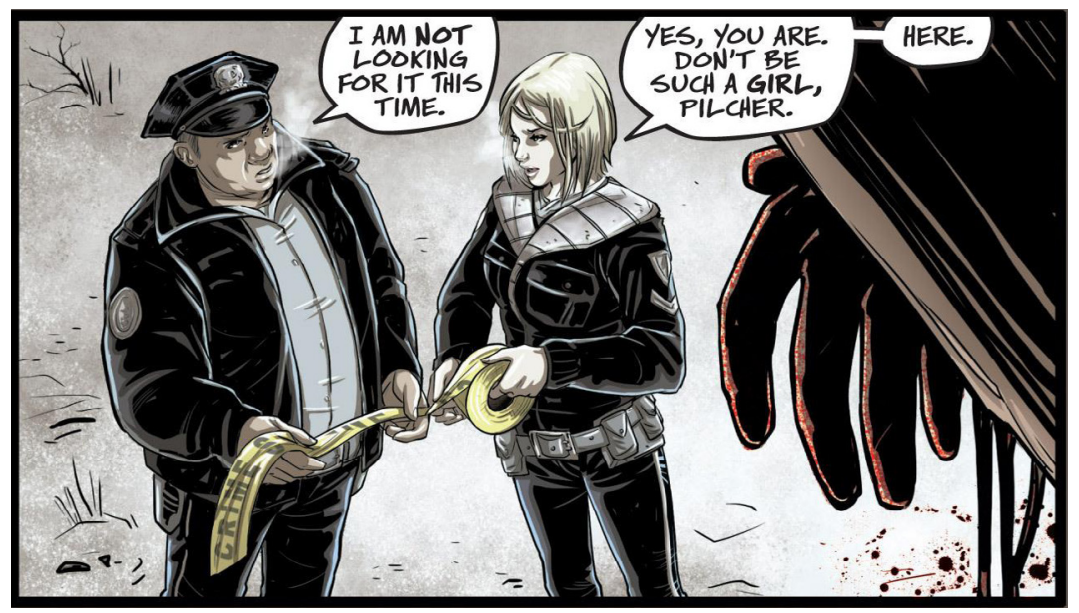

Fonte: MARZ, 2013, p. 5 (letreiramento por Troy Peteri)

A justificativa de Troy se baseia na mudança de artista entre os arcos. Segundo ele, a arte da ilustradora de Borne Again, Laura Braga, parece orgânica e naturalística, e ele procurou refletir esse feitio em seu trabalho. Ele diz também que procura mudar o estilo para combinar com o resto da obra quando há uma mudança significativa no regime de uma série ou quando há um relançamento. De fato, na edição 180, em que se inicia um novo arco e há novo escritor e novo desenhista, o letreiramento muda sua aparência mais uma vez. 
Em relação ao ofício em geral, o letreirista considera seu trabalho como exercício de design gráfico, o que é uma relação consistente se o design gráfico for definido como prática profissional específica "relativa ao ordenamento estético-formal de elementos textuais e não-textuais que compõem peças gráficas destinadas à reprodução com objetivo expressamente comunicacional” (Villas-Boas, 2003, p. 7). Troy afirma ainda que a principal atribuição do ofício é "tornar a página tão facilmente legível e atraente aos olhos quanto possível, deixando a própria arte e texto contarem a história" (tradução nossa). Para atingir esse propósito, o letreiramento envolve a disposição gráfica do texto com cuidados em relação à ilustração em prol de uma representação visual eficiente do enredo, então, observa-se correspondência entre os conceitos de design gráfico e letreiramento.

Troy é adepto do letreiramento digital, o que significa que suas principais ferramentas de trabalho são o computador e programas específicos. Alguns efeitos sonoros são desenhados por ele (não foi esclarecido se são escaneados ou traçados em um software), mas é mais frequente usar fontes existentes para a transcrição dos scripts. Como está há muitos anos no ramo, o letreirista diz que a escolha da fonte para cada caso já se tornou uma segunda natureza. Acrescenta também que, como algumas convenções do letreiramento estão bem estabelecidas, existem situações em que a escolha é óbvia, como o uso de letras grossas para sons bruscos.

\section{TODD KLEIN}

Todd Klein trabalha como letreirista desde 1977. Até o momento da publicação desta dissertação, o profissional foi vencedor da categoria "melhor letreirista" dezesseis vezes pelo Eisner Awards e nove vezes pelo Harvey Awards, ambas consideradas as maiores premiações de quadrinhos dos Estados Unidos.

Klein iniciou sua carreira na DC Comics, ensinado por John Workman e inspirado por outros atuantes da área. Em 1987, ele se tornou um profissional autônomo, prestando serviços a várias editoras.

Nessa época, o trabalho era todo feito a nanquim. O letreirista explica ${ }^{33}$ que os procedimentos do letreiramento manual variavam, mas o mais comum consistia em receber as páginas com as ilustrações a lápis, juntas a um script e instruções de posicionamento dos textos. Assim que as palavras estavam todas inseridas, as páginas eram mandadas para a arte-final. Também era comum conceber o letreiramento em papel vegetal por cima de fotocópias das páginas. Em seguida, era feita uma fotocópia do papel vegetal letreirado e os textos eram inseridos nas ilustrações por colagem.

$33 \quad$ KLEIN, T. Letterman: The Font-astic World of Award-Winning Letterer Todd Klein: depoimento. [Ago. 1999]. Sequential Tart, v. 2, n 8. Entrevista concedida a Laura DePuy. Disponível em: <http://www.sequentialtart.com/archive/aug99/klein.shtml>. Acesso em: abr. 2015. 
Figura 111. Letreiramento feito em papel vegetal sobre fotocópia da arte

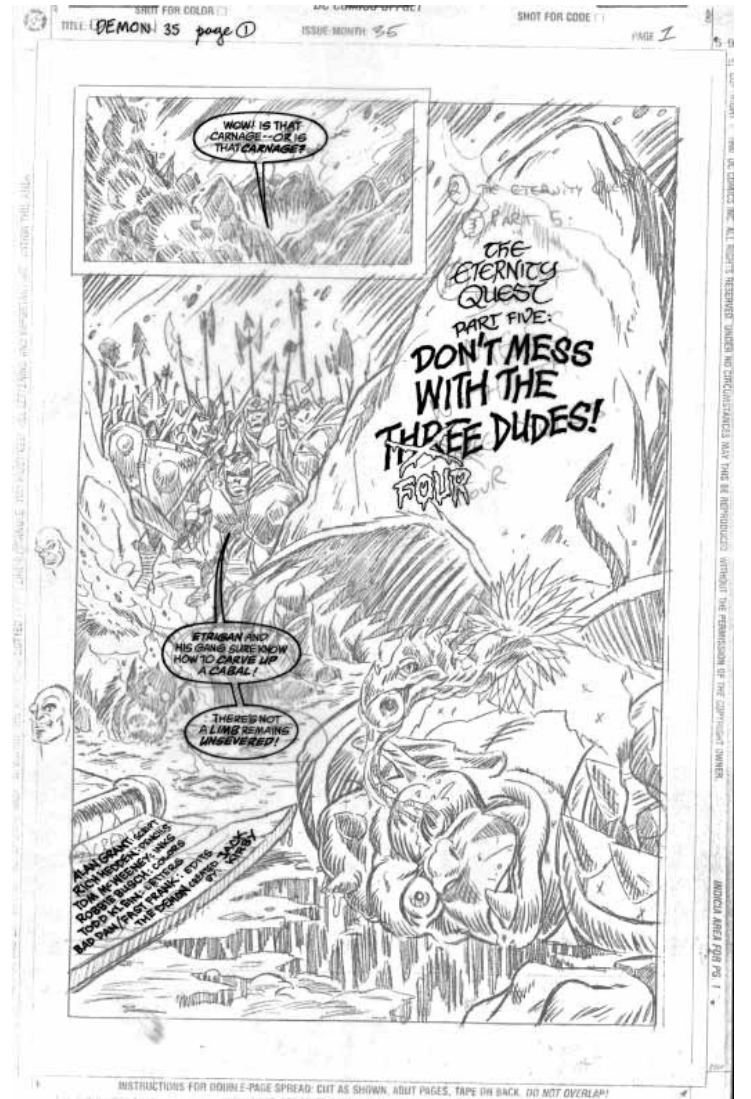

Fonte: http://kleinletters.com/BuyStuffTop.html (abr. 2015)

Quando o letreiramento digital começou a emergir no fim dos anos 80, Klein foi resistente à princípio, mas eventualmente mudou de ideia ao perceber que essa era a "onda do futuro". Em 1994, adquiriu um computador e encomendou de Richard Starkings e John Gaushell fontes baseadas em sua própria letra. Para isso, ele enviou algumas páginas letreiradas para que a dupla tivesse uma ampla gama de letras e símbolos que pudessem usar como exemplos.

As fontes chegaram em um disquete, as quais serviram de modelo para Todd aprender a como criar suas próprias fontes. A partir de então, dezenas foram criadas para atender às diferentes necessidades das obras trabalhadas, em complemento ao uso de fontes comerciais. O motivo principal para ter se convertido ao letreiramento eletrônico foi a poupança de tempo que ele ganhou com o uso dos softwares.

Um de seus trabalhos mais conhecidos, pelo qual levou seis dos prêmios mencionados, é a obra Sandman, escrita por Neil Gaiman. A história é repleta de seres incomuns, alguns inventados e outros extraídos de diversas mitologias, fazendo com que Todd desenvolvesse um conjunto de estilos únicos condizentes com as particularidades dos personagens. Em seu blog ${ }^{34}$, o letreirista comenta que a série foi o maior desafio criativo que tivera até então. Blieck ${ }^{35}$ cogita que, por esse traba-

34 Lettering, continued: the 1990s. Disponível em: <http://kleinletters.com/Lettering4.html>. Acesso em: abr. 2015.

35 Blieck Jr., Augie De. The underappreciated art of lettering. Comic Book Resources, 3 dez. 1999. Disponível em: <http://www.comicbookresources.com/?page=article\&id=13101>. Acesso em: 
Iho, Klein fora responsável pela popularização do uso de múltiplos estilos de letras nos quadrinhos. Embora esse método já tenha sido utilizado antes, Blieck afirma que ninguém havia feito uso com tanta frequência e tanta eficiência quanto Todd Klein, e que foi após Sandman que essa prática se tornou usual.

Como dito no capítulo 2, a popularidade de Sandman ajudou a desmistificar o uso de caixa alta como regra dos quadrinhos. A fala do protagonista apresenta letras minúsculas, com o texto branco envolto por um balão disforme negro. Apesar de o conjunto completo ressaltar a personalidade sombria de Sonho, Klein admite que a ideia das cores inversas foi interferência da editora Karen Berger, e que ele mesmo era contra, pois a técnica consistia em fazer fotocópias em negativo e isso poderia reduzir a legibilidade do texto.

Em resposta ao questionário (Apêndice B), o letreirista acrescenta que o escritor já tinha algumas ideias específicas e orientava-o por meio do roteiro. Para o/a personagem Desejo, por exemplo, a voz foi descrita como exótica e enigmática, ou seja, um formato de letra com nuances que combinassem com sua provocação sedutora e um quê de mistério que valorizasse seus trejeitos enigmáticos. Com essas diretrizes, Klein obteve uma letra "um pouco oriental, um pouco Art Nouveau." 36

Figura 112. Letreiramento para o(a) personagem Desejo, em Estação das Brumas

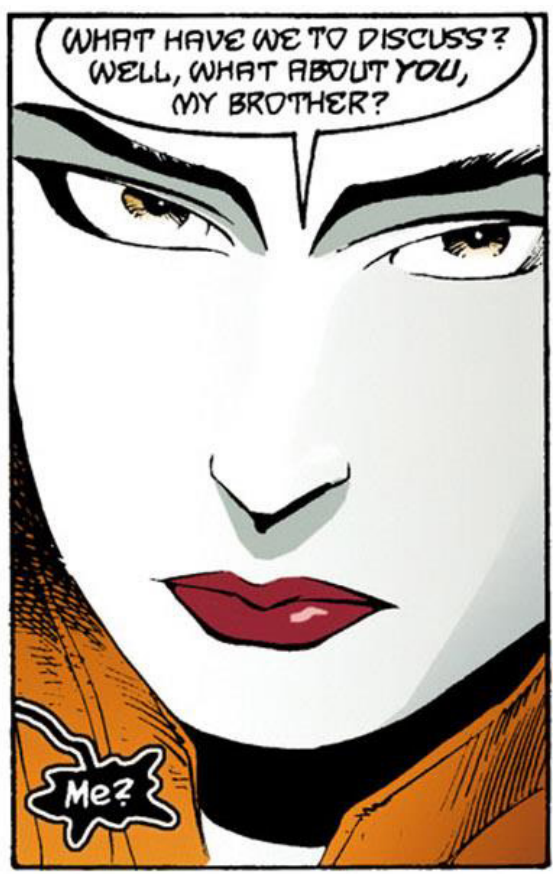

Fonte: Gaiman, 1990-1991, no 21, p. 29 (letreirado por Todd Klein)

A participação da editora e do escritor para definir a forma de letreiramento para os personagens mostra que se trata de um processo criativo aberto. Para o desenvolvimento de logos, Klein (2003, p. 57) conta que as ideias têm origem em

abr. 2015.

36 KLEIN, T. Neil Gaiman/Sandman 3. Disponível em: <http://kleinletters.com/NeilGaimanLettering3.html>. Acesso em: abr. 2015. 
conversas com o escritor e, muitas vezes, também com o artista. Em casos em que o conjunto de estilos já está estabelecido, a comunicação com outras partes da produção se torna desnecessária, como ratifica Klein, que diz haver projetos em que não há diálogo com os outros profissionais.

Sobre a profissão, o letreirista descreve em seu livro, de maneira sucinta, que seu trabalho se resume em "inserir as palavras do escritor nas ilustrações do artista" (Klein, 2004, p. 83, tradução da autora). Ele explica que cabe ao letreirista a criação de tudo na página de quadrinhos que é feito de palavras, com exceção daquilo que o artista já tenha colocado. Segundo ele, para funcionar bem, o letreiramento deve ser preciso, legível e posicionado na ordem correta, de modo a facilitar a leitura. Além disso, Klein considera como deveres complementares de um bom letreirista adicionar toques criativos e estilísticos que melhoram o produto final.

A respeito do mercado, Klein desaconselha a entrada na indústria do letreiramento. Segundo ele, o letreiramento manual é a melhor maneira de aprender o ofício e não é desejado pelas grandes empresas, e muitas novas empresas menores conhecem apenas o letreiramento digital. Além disso, as grandes empresas estão tentando ao máximo realizar essa etapa dentro da própria equipe, fazendo com que profissionais autônomos tenham dificuldade em conseguir trabalho, sendo um obstáculo ainda maior para iniciantes. Outro argumento é o de que a oferta de pequenas editoras para o letreiramento feito no computador é de pouco ou nenhum dinheiro. Ademais, muitos ilustradores estão se responsabilizando por essa etapa em seus próprios trabalhos, incentivados pelo dinheiro economizado por fazer o máximo da produção no computador quanto possível, acelerando o fluxo de trabalho e cortando despesas de envio. ${ }^{37}$

Quando perguntado sobre a notabilidade do ramo, Klein estima que $10 \%$ do público de fãs de quadrinhos presta atenção aos detalhes de quem faz cada etapa e reflete sobre os componentes separadamente, como ilustração, arte-final, colorização e letreiramento. Apesar de ser uma baixa porcentagem, o letreirista compara a situação a outros ofícios e não vê motivos para reclamar:

Quantos leitores de livros pensam sobre tipografia ou o design da capa? Quantos cinéfilos consideram a trilha sonora, cenografia ou iluminação? Eu acho que a maioria de nós inconscientemente absorve essas contribuições, mas poucos de nós pensam sobre eles conscientemente. Eu não acho que muito provável que isso mude, e eu aprecio aqueles que percebem o que eu faço.

(Klein, ago. $2003^{38}$, tradução da autora)

$37 \quad$ KLEIN, T. Todd Klein interview: depoimento. [Ago. 2003]. Entrevista concedida a Eroom Nala. Disponível em: <http://eroomnala.bravepages.com/Klein.html>. Acesso em: abr. 2015. 38 Idem. 
Lilian Toshimi Mitsunaga Farias é formada em Arquitetura pela USP e trabalha com letreiramento nos quadrinhos desde 1980. Em sua carreira, já foi funcionária de diversas editoras ${ }^{39}$, até que seu trabalho se consagrou o bastante para que ela pudesse prestar serviços de seu escritório e montar seu próprio estúdio, Lua Azul.

Seu capricho resultou em demanda pela garantia de primor $^{40} \mathrm{e}$ foi reconhecido com dois troféus. Em 1999, a 11ª edição do Troféu HQ Mix, principal premiação nacional de quadrinhos, teve pela primeira e única vez a categoria "Letrista", pela qual Lilian Mitsunaga foi condecorada vencedora. Em 2003, foi premiada novamente no $19^{\circ}$ Prêmio Angelo Agostini em "Arte técnica (colorista e letrista)", categoria que seria contemplada apenas por mais um ano.

No questionário (Apêndice $\mathrm{C}$ ), ela conta que aprendeu a ler aos quatro anos e seu gosto por gibis surgiu também logo cedo. Já era apaixonada pelos quadrinhos em sua graduação, período em que a vontade de ajudar financeiramente seus pais levou-a a tentar uma vaga de letreirista na Editora Abril, que oferecia flexibilidade de horário para o cargo. Após três meses de treinamento, conseguiu ser contratada.

Começou com os quadrinhos Disney, mas foi através dos quadrinhos de heróis que seu nome passou a aparecer, pois esse genêro comumente apresentava os créditos dos colaboradores nacionais ao lado dos artistas estrangeiros.

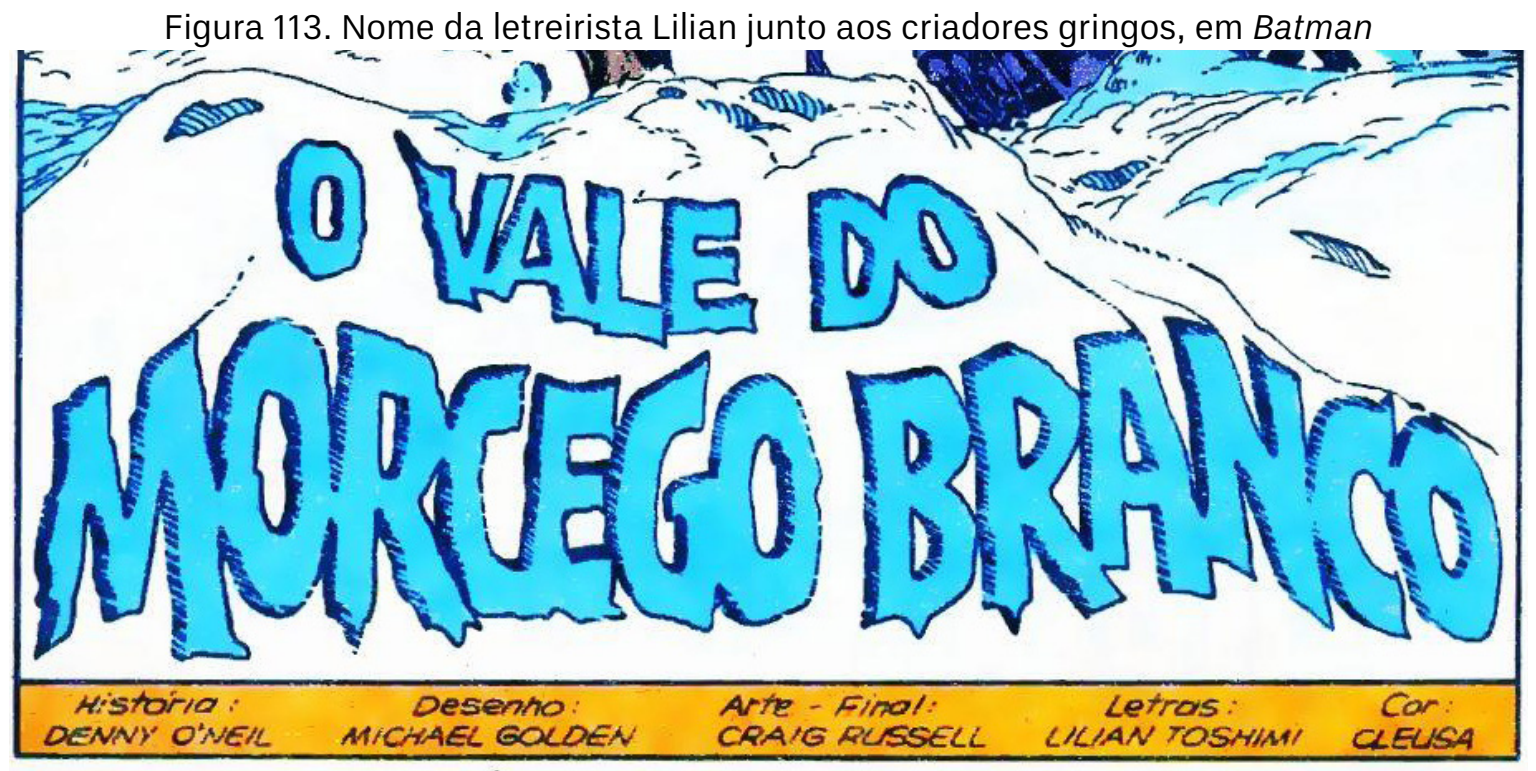

Fonte: O'NEIL; GOLDEN, 1984, p. 62 (letreirado por Lilian Mitsunaga)

39 Em algumas publicações, Lilian Mitsunaga assina como "Miriam Tomi", pseudônimo criado para evitar conflitos quando trabalhava com editoras concorrentes.

40 VEIT, L. A linha de quadrinhos da WMF Martins Fontes: depoimento. [24 nov. 2014]. A Pilha. Entrevista concedida a Érico Assis. Disponível em: <http://apilha.com.br/a-linha-de-quadrinhos-da-wmf-martins-fontes/>. Acesso em: abr. 2015. 
Nessa época, o principal método de impressão era o de quadricromia, que envolve a reprodução das cores através de apenas quatro cores independentes e sobrepostas: ciano, magenta, amarelo e preto. A letreirista lembra que algumas editoras evitavam mexer na arte, pois a técnica de impressão dificultava o retoque, e a modificação só era permitida quando o fundo era chapado ou branco, como no caso do título da imagem anterior.

Segundo a letreirista, as letras eram aplicadas diretamente sobre as páginas ilustradas. Lilian trabalhava exclusivamente com letreiramento a nanquim, com canetas e penas, até adquirir seu primeiro computador em 1996. Então, passou a se familiarizar com o uso de fontes e softwares (Mitsunaga, 2015) e começou a desenvolver suas próprias coleções de caracteres.

Com o tempo, as páginas passaram a ser escaneadas e enviadas em formato digital, sobre as quais era aplicado o texto em camadas. As ferramentas tradicionais, no entanto, não foram aposentadas: uma técnica utilizada pela letreirista para agilizar o processo é escrever em cima das artes a lápis, possibilitando o letreiramento ao mesmo tempo em que as páginas são arte-finalizadas e colorizadas.

Assim como os atuantes do ramo nos Estados Unidos, a profissional brasileira é responsável pelo tratamento gráfico de todos os textos nas páginas de quadrinhos: falas, pensamentos, narrações, títulos dos capítulos, paratextos linguísticos e quaisquer palavras que precisem ser inseridas na obra. Em alguns trabalhos, ela se encarregou de todo o projeto gráfico da publicação, incluindo diagramação das páginas iniciais e finais (editorial, expediente, etc.).

No questionário, ela diz que as incumbências variam de editora para editora, portanto, a polivalência é um grande diferencial no segmento do letreiramento e é uma das características que fez com que Lilian se destacasse durante o tempo de trabalho no ramo. "Rapidez, qualidade e pontualidade" são as qualidades apontadas pela própria profissional a respeito de seu serviço, e os motivos de seu nome ser associado à excelência em letreiramento.

Outra diferença entre as editoras recai sobre a forma de comunicação. O primeiro contato entre a letreirista e o editor geralmente é através de uma reunião, e depois a relação se restringe aos métodos eletrônicos, como telefone e e-mail. Ela explica que nem todos os demandantes de seu serviço residem no mesmo estado, então os dispositivos de comunicação à distância se tornam mais convenientes.

Nesses diálogos, estabelece-se o que será feito na obra. Muitos dos seus trabalhos são quadrinhos traduzidos e reedições de quadrinhos nacionais; em alguns casos, a editora pede que seja mantido o máximo de similaridade com o trabalho original e Lilian procura criar fontes semelhantes às letras dos textos originais. $\mathrm{Na}$ obra Habibi, a letreirista concebeu três fontes para reproduzir a caligrafia do autor Craig Thompson. Não obstante, algumas páginas ainda demandaram novos estilos de letra, os quais foram desenhados digitalmente. ${ }^{41}$ (Figura 114)

41 ASSIS, E. Mitsunaga, Ronin. Blog da Companhia, 18 jun. 2012. Disponível em: <http://www. blogdacompanhia.com.br/tag/lilian-mitsunaga/>. Acesso em: abr. 2015. 
Figura 114. Página em que foi necessário desenhar letras em programa digital.
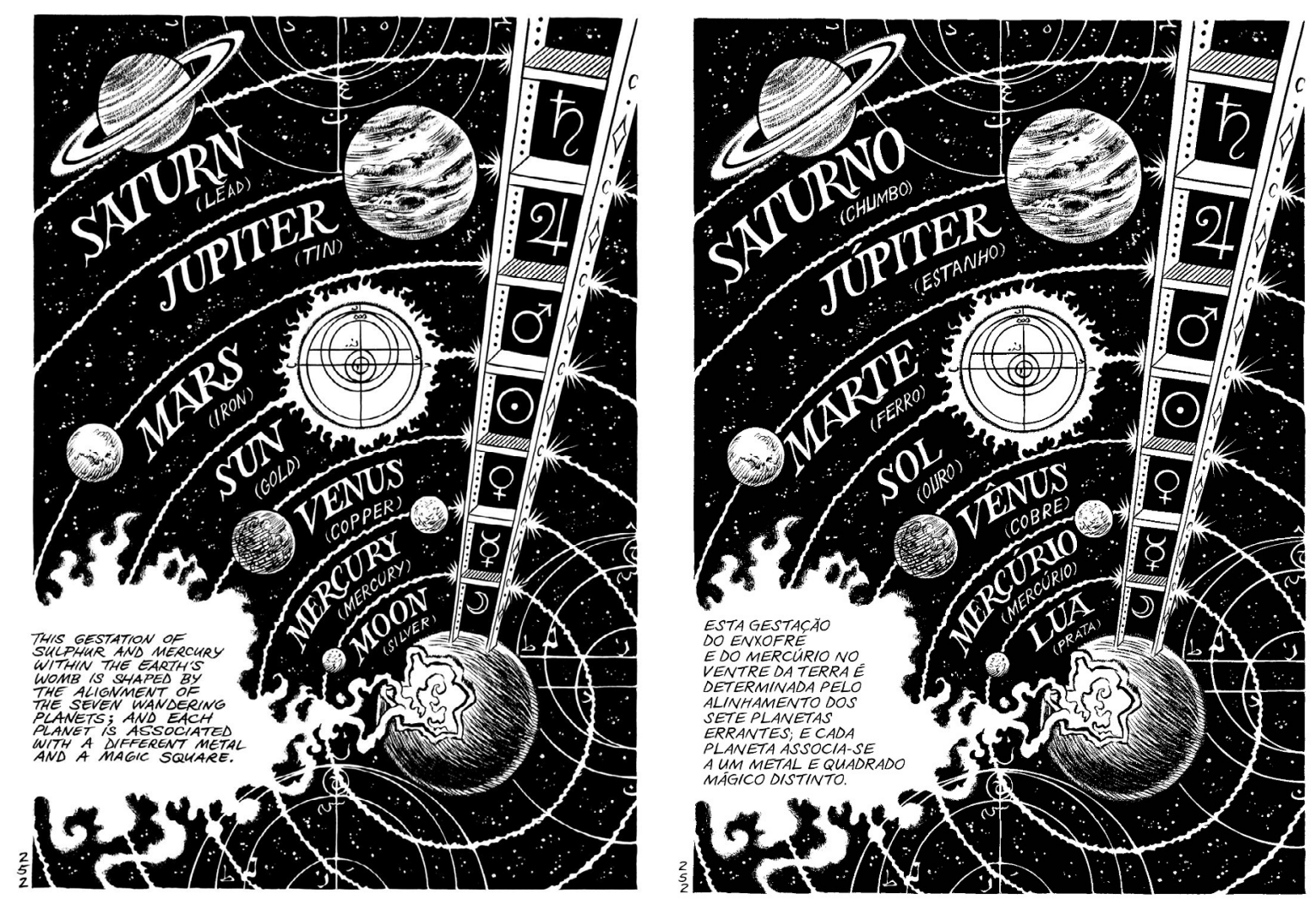

Fontes: ThOMPSON, 2011, p. 252 e THOMPSON, 2012, p. 252, respectivamente

$\mathrm{Na}$ imagem acima, a narração traduzida na parte inferior esquerda foi escrita com o uso de fonte criada pela letreirista. Os nomes dos planetas, no entanto, precisaram de um estilo além do acervo disponível, necessidade solucionada com caracteres desenhados em programa gráfico vetorial.

Outro autor cujas obras traduzidas foram letreiradas por Lilian é Will Eisner. O quadrinista advogou a favor do letreiramento manual como "o modo mais idiossincrático e expressivo de inserir palavras nos balões e nas caixas de texto" (Eisner, 2010, p. 26) e argumentou que fontes eletrônicas possuíam "um efeito 'mecânico' que interfere na personalidade da arte feita à mão livre" (idem), sendo melhor usadas em histórias cuja estética não demande o caráter manual. Contudo, a letreirista brasileira persistiu no uso do computador para inserir os novos textos nas HQs de Eisner. Para manter a identidade da obra e reduzir o impacto do "efeito mecânico", Lilian utilizou a grafia do autor como base para a concepção de fontes.

Na Figura 115, temos algumas das fontes desenvolvidas por Lilian para retratar a escrita de Eisner para as falas. O uso da tipografia fica especialmente óbvio na sequência de "Hein?" no primeiro quadro, em que as duas sentenças possuem tal semelhança que sera dificilmente exequível na escrita à mão. Já no desenho de um pedaço de papel, pela diferença de formato entre os mesmos caracteres e pelas ligaduras caligráficas, o texto parece ser escrito manualmente. 
Figura 115. Letreiramento por Lilian Mitsunaga em obra traduzida de Will Eisner

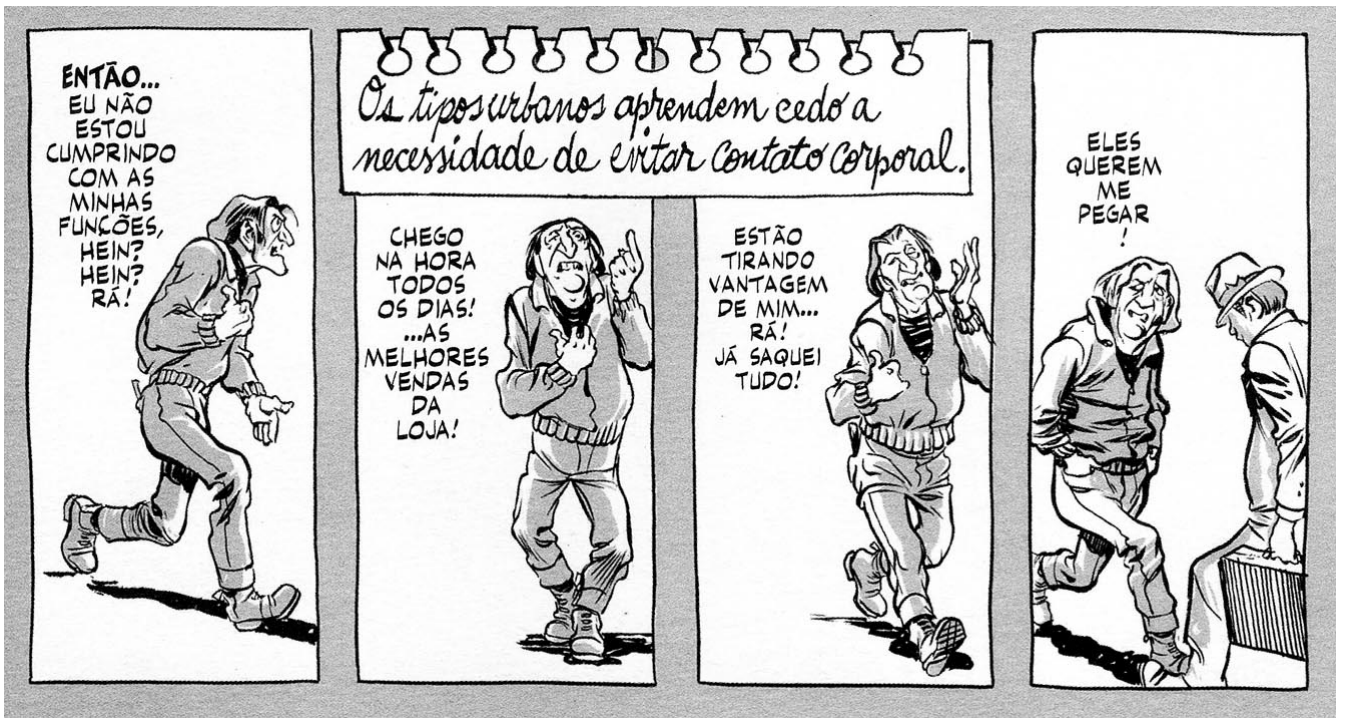

Fonte: EISNER, 2009, p. 310

Figura 116. Versão original da obra de Will Eisner

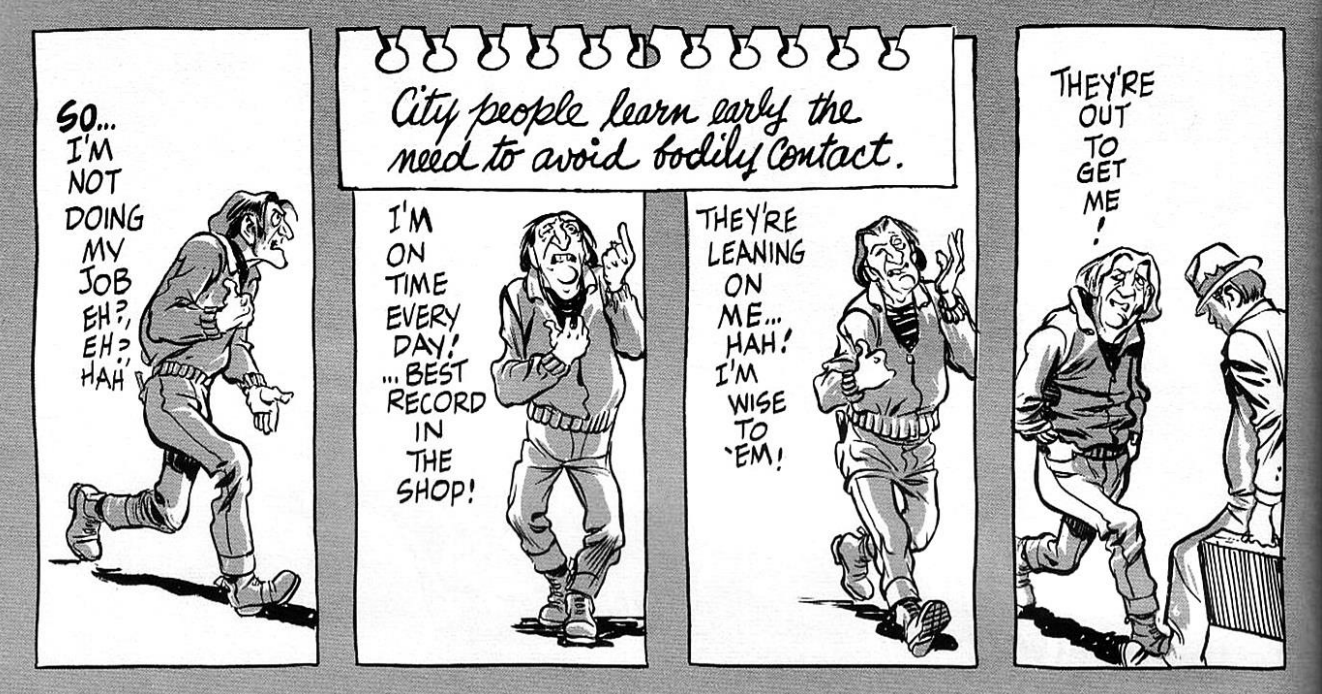

Fonte: EISNER, ago. 2000, p. 76

Ao comparar a caligrafia com a versão original (Figura 116), algumas semeIhanças são logo percebidas, como a tendência de inclinação à direita e a altura desigual das letras. Uma análise mais detalhada revela a similaridade da sílaba ne em "necessidade" e em "need" e da sílaba con em "contato" e em "contact". Fica evidente o estudo minucioso da letreirista sobre o estilo a ser representado. O texto foi escrito à mão, utilizando-se de uma mesa digitalizadora para que o resultado aparecesse direto na tela do computador. De certa forma, apesar de ter sido elaborada digitalmente, a versão brasileira conta com a presença da grafia do autor.

Na mesma obra, até as placas do cenário foram reletreiradas conforme as letras originais, assim, constata-se o esmero de Lilian em replicar o estilo do artista até nas inscrições de menos destaque. 
Como a letreirista trabalha com obras traduzidas e com nacionais, ela foi questionada sobre a diferença entre os dois tipos de publicação. Nas HQs estrangeiras, não há o trabalho de desenhar o suporte, porém, quando as letras interferem na ilustração, é acrescentada a etapa de reparar a arte para substituir os textos. Nos trabalhos produzidos no Brasil, é preciso um diálogo com o autor para definir a forma do letreiramento e a profissional seleciona fontes, tipos de balão e cores, passo menos demorado nas histórias importadas porque normalmente segue-se 0 padrão da publicação original.

De acordo com Lilian, a colaboração por parte da equipe de produção pode facilitar o letreiramento. Artistas que possuem a sensibilidade de posicionar os personagens na sequência em que falam evitam medidas improvisadas no letreiramento para guiar a ordem de leitura. Já os escritores ajudam ao prever o espaço necessário para a inserção das palavras, visto que textos muito longos comprometem a beleza da composição da página. Os copidesques, revisores que cuidam do ajuste textual, também podem solucionar esse tipo de problema.

\section{NATE PIEKOS}

Nate Piekos é bacharel em design, formado pela Rhode Island College em 1998. De acordo com as respostas ao questionário (apêndice D), sua graduação teve foco no design de identidade visual corporativa. Até então, não pensava em estabelecer carreira no segmento das histórias em quadrinhos, mas já produzia sua própria obra independente, The whole enchilada, para a qual desenvolveu algumas fontes aproveitando o conhecimento adquirido nas aulas de tipografia. Devido à falta de fontes gratuitas específicas da mídia, Piekos decidiu disponibilizar as suas próprias em 1999, fundando o estúdio Blambot Comic Fonts \& Lettering. Segundo o fundador, a ideia veio durante a leitura de um livro sobre HTML.

Blambot é uma indústria de fontes tipográficas para uso em histórias em quadrinhos, dividida em categorias como "fontes para diálogo" e "fontes para efeitos especiais". Além desse comércio virtual, a empresa também presta serviços de letreiramento e, desde sua criação, vem trabalhando com editoras independentes até clientes grandes como Marvel Comics, DC Comics, Oni Press e Dark Horse Comics.

Piekos tem outra companhia, a Providence Type, para a venda de tipografias não voltadas para quadrinhos. Quando perguntado sobre o que diferencia a fonte para $\mathrm{HQs}$ das demais fontes, Nate respondeu que é principalmente a organicidade do design e ressaltou a semelhança com a chamada "letra de arquiteto". Ele comenta que os leigos costumam associar o estilo textual dos quadrinhos a uma escrita infantilesca ou ao letreiramento aplicado às onomatopeias da série televisiva do Batman dos anos 60. Contudo, suas reais especificidades são complexas e difíceis de serem precisamente descritas. 
Em relação ao serviço, Nate explicou que as principais funções de um letreirista são a inserção das falas, narrações, créditos e criação do design de título. Em complemento às tarefas mencionadas por Troy Peteri, Todd Klein e Lilian Mitsunaga, Piekos inclui a interpretação do script no que for relacionado às "regras especiais do letreiramento". Os roteiros normalmente indicam determinadas propriedades a serem consideradas na inserção de texto, como o uso de itálico ou negrito para mostrar palavras que devam apresentar algum destaque gráfico. As descrições de cada quadro também oferecem base para o trabalho do letreirista, que, por meio do entendimento da cena, deduz tonalidade e volume de voz do personagem.

Figura 117. Trecho do roteiro para a parte um de Brain Boy \#1: PSY vs. PSY, escrito por Fred Van Len-

$$
\text { te, em 2013, para a editora Dark Horse }
$$
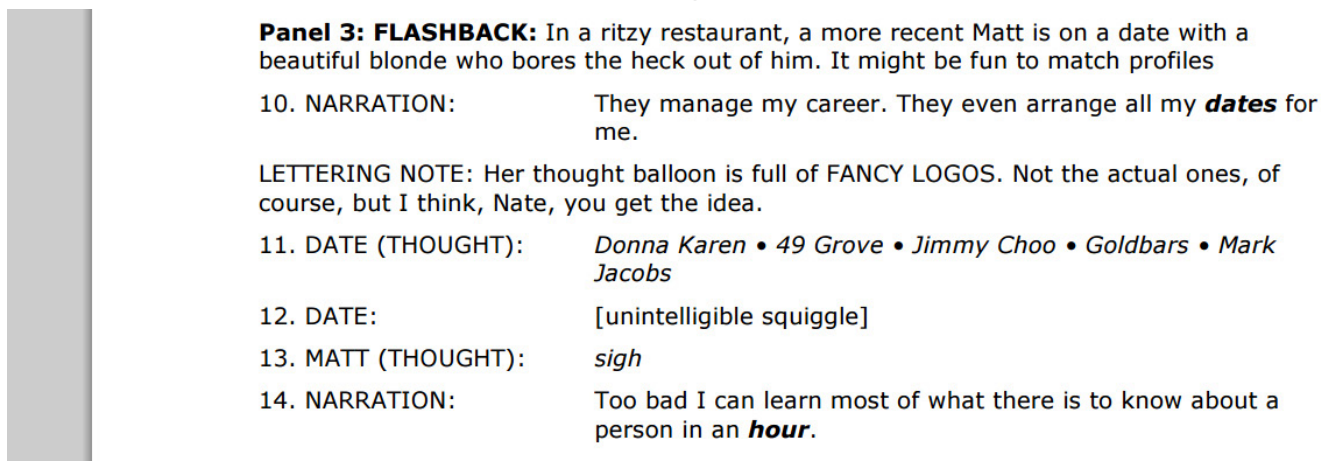

Fonte: http://www.fredvanlente.com/brainboy1script.pdf (2015)

Na Figura 117, o escritor Van Lente descreve a situação do quadro 3 da terceira página da história e, em seguida, enumera as partes que precisam ser escritas na obra - o número corresponde ao posicionamento de cada texto, muitas vezes previamente estabelecido pelo editor. À esquerda, Van Lente coloca o descritor, a quem é atribuído o texto à direita; nessa passagem, existem três descritores diferentes: narração, a mulher e o protagonista Matt.

Entre parênteses, explica-se que alguns balões devem ser de pensamento, por meio da chamada "(THOUGHT)" e a função é reforçada utilizando o itálico no texto correspondente. Nate explica ${ }^{42}$ que o recurso também é utilizado para determinar outras propriedades, como sussurro, grito e canção. O escritor também marca algumas palavras em negrito e itálico para demonstrar ênfase. Para o não-verbal, como o "rabisco ininteligível" (número 12), a diferenciação foi feita através do uso de colchetes.

A interpretação mencionada por Nate não se limita apenas ao entendimento dessas regras e legendas, que variam de escritor para escritor, como também abrange a intenção do escritor. Para a passagem número 11, Van Lente insere uma nota ao letreirista: "O balão de pensamento dela é repleto de LOGOS EXTRAVAGANTES. Não as verdadeiras, é claro, mas eu acho, Nate, que você captou a ideia"

42 PIEKOS, N. Comic script basics. Blambot, out. 2013. Disponível em: <http://www.blambot. com/comicscript.shtml>. Acesso em: abr. 2015. 
(tradução da autora), onde ele claramente confia na forma como o profissional compreenderá seus planos. O resultado da interpretação do letreirista encontra-se na Figura 118, onde todas as diretrizes sugeridas foram seguidas.

Figura 118. Quadro referente à passagem do roteiro de Brain Boy

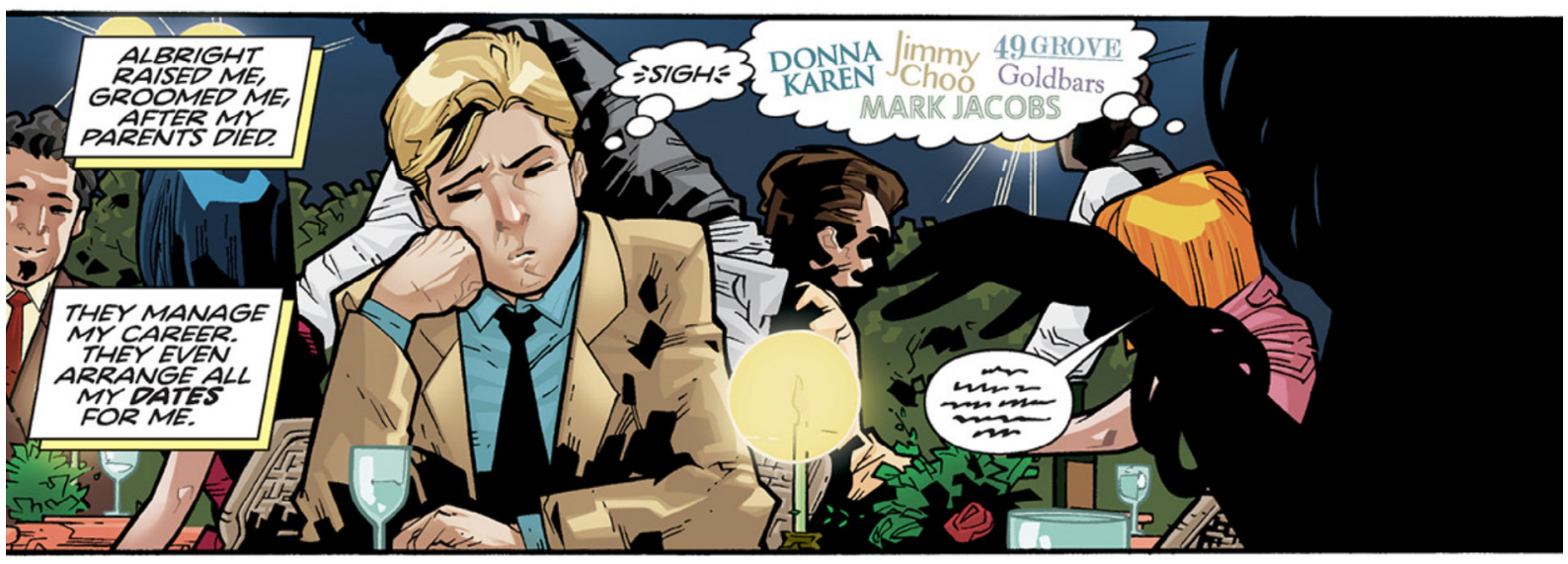

Fonte: VAN LENTE; SILVA, 2013, p. 3. (letreiramento por Nate Piekos)

Quando ocorre um caso dúbio que o letreirista não pode desvendar pelo contexto, o profissional pode recorrer ao próprio autor do enredo. Em resposta ao questionário, Nate diz que, embora lide principalmente com editores porque são os intermediários entre os envolvidos na produção de HQs, ele troca e-mails com os artistas e escritores sobre dúvidas ou outros assuntos da obra.

Nate Piekos considera que tarefas mais elaboradas como produção gráfica da obra, concepção da logo e criação de fontes sejam encargos sobrejacentes aos letreiristas mais experientes em design. Assim como Troy, Nate acredita na existência de relação direta entre design e letreiramento. Mais além, ele afirma que 50\% do visual das histórias em quadrinhos sejam design gráfico, sendo a outra metade ilustração. A primeira parte diz respeito ao controle da fluidez e da agradabilidade aos olhos em cada página, e é onde se insere o lettering, definido por ele como "a representação visual de todo indício audível e de toda linha de diálogo" dentro de uma obra de quadrinhos. ${ }^{43}$

Outro aspecto pertinente ao letreiramento é o "bom senso" para a escolha de fontes, o qual Piekos exemplifica com o uso de fontes tortas e garranchosas para monstros e fontes molhadas e suaves para sons molhados e suaves. Como as famílias tipográficas não possuem nível de umidade nem textura física, entende-se "bom senso" como a seleção segundo o que já se foi convencionado.

Em seu tempo de mercado, Piekos desenvolveu sua própria meta (fazer com que o letreiramento complemente a arte a ser letreirada) e sua própria forma de trabalho. Quando inicia uma série, é desenvolvido um guia de estilos de letreiramento, composto por um conjunto de fontes a serem utilizadas durante o projeto. São pre-

$43 \quad$ PIEKOS, N. The things you need to know to make a great comic. Urban 75, fev. 2001. Disponível em: < http://www.urban75.org/comics/faq.html >. Acesso em: abr. 2015. 
vistas as principais categorias para uso de fontes diferentes: diálogo, narração, subtítulo, onomatopeias comuns, entre outros. Para cada uma, Nate seleciona ou cria uma fonte que, juntamente às outras, integre o estilo visual particular da série.

O letreirista fundamenta sua seleção em um estudo prévio sobre o tema e a época do enredo, consultando sua extensa biblioteca de referências tipográficas, que contém pôsteres de filmes, capas, artes em grafitti e até embalagens de produtos. Para The Black Beetle, a pesquisa sobre o gênero pulp e heróis detetives embasou a concepção de uma nova fonte para compor os textos de diálogo e a seleção, para os outros tipos, de fontes já disponíveis em sua empresa. ${ }^{44}$

Em alguns trabalhos, a criatividade fica restrita a imitar letras de outras pessoas. É o caso em que artistas solicitam o serviço da Blambot para a criação de fontes com base em suas próprias grafias. Também encaixa-se o pedido de letreiramento para a reedição ou continuação de uma obra previamente letreirada à mão, como ocorreu com Elfquest, em que Nate criou uma fonte com base nas letras de Wendy Pini. ${ }^{45}$ Para isso, Wendy selecionou páginas com exemplares do que ela considerava seu melhor letreiramento e a editora providenciou a versão digitalizada delas em alta resolução para Nate, que escolheu algumas letras para serem usadas de modelo para a nova fonte. (Figura 119)

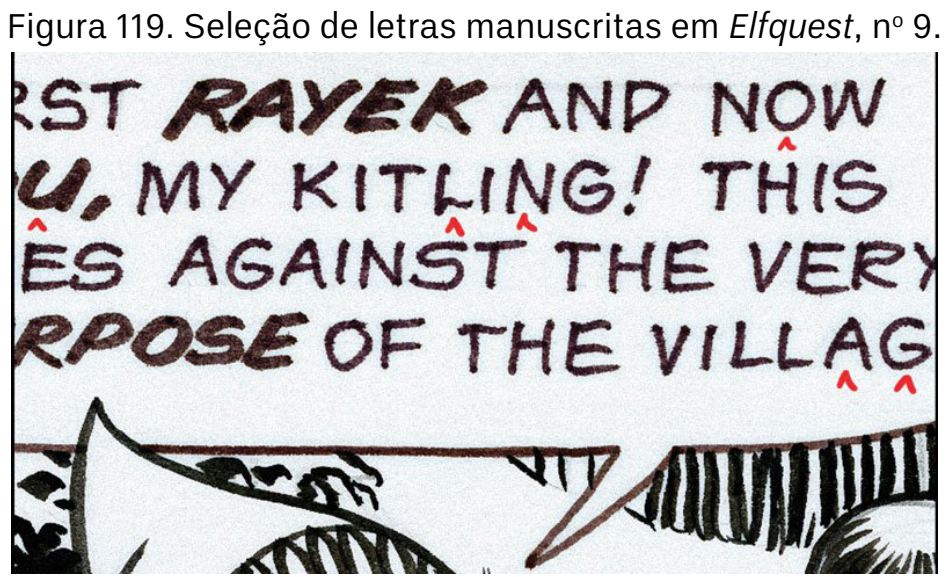

Fonte: http://i2.wp.com/boingboing.net/wp-content/uploads/2014/01/piekos-2.jpg (2015)

Profissionalmente, além de letreirista e desenvolvedor de fontes, Piekos produz também sua própria história em quadrinhos, Atland, veiculada pela internet desde 2004. Quando perguntado sobre os cuidados tomados ao escrever e desenhar a história para valorizar o letreiramento, Nate respondeu que a principal precaução se refere às limitações de espaço. Por experiência, ele sabe o volume textual adequado e também consegue prever a área necessária para o texto durante a ilustração.

$44 \quad$ PIEKOS, N. The Black Beetle: anatomy of a font - a lettering feature by Nate Piekos. Dark Horse, out. 2013. Disponível em: <http://www.darkhorse.com/Blog/1242/anatomy-pulp-font-lettering-feature-nate-piekos>. Acesso em: abr. 2015.

45 PIEKOS, N. Creating a font from a classic comic. Boing Boing, jan. 2004. Disponível em: <http://boingboing.net/2014/01/30/creatingafont.html>. Acesso em: abr. 2015. 
Ron Marz é um escritor de Nova lorque que produz roteiros para quadrinhos desde 1990. Ele é conhecido principalmente por seu trabalho em O Surfista Prateado e em Lanterna Verde. Este profissional foi convidado a colaborar no projeto (Apêndice E) devido ao zelo prestado para facilitar a etapa do letreiramento.

É comum escritores entregarem aos letreiristas roteiros com muitos erros de ortografia e gramática, criando uma função a mais de efetuar correções antes de inserir o texto. Para Ron, "o escritor (ou o editor) deve ao letreirista um roteiro impecável que pode ser transcrito exatamente como aparece." (Marz, 2012, tradução da autora) O escritor acredita que um letreiramento mal executado é o jeito mais fácil de um livro parecer amador, então ele procura minimizar qualquer chance de erro.

Os procedimentos adotados para alcançar o primor se iniciam com as ideias amadurecidas passadas para o papel, onde já são divididas por páginas. Segundo Marz ${ }^{46}$, cada página é preciosa e deve ter um propósito, senão, deve ser repensada. Em seguida, o enredo é quebrado em quadros. Nesse estágio, Ron escreve alguns esboços de diálogo para saber o direcionamento da narrativa, os quais não possuem muita viveza, estilo ou graça, mas servem para transmitir o que será dito, em que ordem e quanto espaço para balões o artista precisará deixar. O manuscrito é passado a um processador de texto, enviado ao editor, depois mandado para o ilustrador e, enfim, para o colorista.

Ron lembra que a mídia das histórias em quadrinhos é colaborativa, então os responsáveis pela produção devem colaborar um com o outro. O escritor segue vários princípios para otimizar o trabalho da equipe. Para ajudar o ilustrador, Ron insere referências específicas da internet no roteiro, quando necessárias, e lhe concede liberdade criativa para interpretar a descrição a seu modo.

O escritor espera que a arte fique pronta para escrever os textos definitivos a serem letreirados. Isso porque ele pode reagir ao que está na página e ajustar o texto para melhor atender à ilustração, por meio do ajuste do comprimento, da ordem das falas ou para cobrir eventuais furos na história. Conforme é feito esse polimento, ele vai enviando o roteiro em partes ao letreirista, sendo que a sequência de envio não necessariamente segue a ordem do enredo.

Para ajudar o letreirista, a regra de ouro de Marz é ter até cerca de 25 palavras por balão ou letreiro, procurando não ultrapassar 30 palavras. Caso a arte não abarque a ordem de falas esperada, ele também se encarrega de reescrever diálogos para evitar cruzamento de rabichos ou posicionamentos de suporte dificultados, problemas que alguns escritores deixam para o letreirista consertar.

$46 \quad$ MARZ, R. Shelf Life: Writing Right... and Righting Writing Wrongs. Comic Book Resources, 10 jan. 2013. Disponível em: <http://www.comicbookresources.com/?page=article\&id=43102>. Acesso em: abr. 2015. 
Outro erro comum é que, como o letreiramento digital é considerado fácil de corrigir, alguns autores fazem várias revisões substanciais para serem incluídas em páginas já letreiradas. Para que o letreirista não tenha retrabalho, Ron procura mandar a versão final do roteiro, com a certeza de que está tudo em ordem, desde os aspectos ortográficos até a seleção das palavras destacadas (palavras sublinhadas na Figura 120).

Outra prática favorável é a de inserir descrições específicas para o letreirista, como o "burst" entre parênteses da figura abaixo, que propõe o uso de um balão explosivo. Além disso, ele toma a precaução de não incluir instruções vagas, tais como "balão triste".

Figura 120. Trecho do roteiro de Shinku, número 7, página 2, escrito por Ron Marz.

PAGE 2
PANEL 1: This is the largest panel on the page, a big reveal to introduce
Shinku. She's grabbing the vampire by the throat, shoving him back against
the wall. The vampire is dropping what's left of the rat, and looks pretty
scared. Shinku's expression is stern. She has her sword in her other hand.
1 Vampire (burst): GHHK!
2 Shinku: Where are they?
PANEL 2: Move in for a closer two-shot of Shinku and the vampire, the
vampire still pinned to the wall. He begins to answer .
3 Vampire: Who?
4 Shinku: The rest of your kind. They're gone.
5 Shinku: Where did they go ?

Fonte: http://www.comicbookresources.com/?page=article\&id=50487 (2015)

De acordo com Todd Klein, Lilian Mitsunaga e Nate Piekos, há pouca comunicação direta com o escritor, dependendo do projeto. No caso de Marz, o contato é mais frequente. Ele, e não o editor, é normalmente o primeiro a ver páginas letreiradas e procura trocar ideias com o letreirista responsável sobre possíveis correções. As revisões e alterações são feitas até Marz chegar em uma versão satisfatória, para a qual é dado o aval para impressão.

Por ser muito exigente com essa etapa, o escritor busca trabalhar com quem tenha um serviço confiável, e o nome favorito a ser solicitado é Troy Peteri. Os dois fizeram parte de uma mesma equipe na editora CrossGen, há mais de dez anos, e as inúmeras obras que produziram juntos contribuíram para uma parceria duradoura. Ter Troy como letreirista agiliza o processo porque, segundo Marz, "ele sabe o que eu estou procurando e eu sei o que ele faz" (tradução da autora), então, não há preocupação sobre o posicionamento dos balões ou quanto à inserção de observações sobre o letreiramento. $O$ escritor afirma que é uma relação de confiança mútua. 


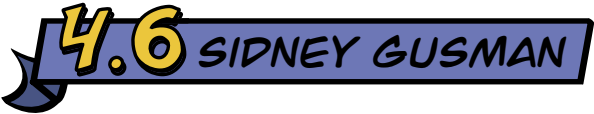

Sidney Gusman é um jornalista formado pela Universidade Metodista de São Bernardo do Campo que escreve sobre HQs desde 1990. Foi sete vezes vencedor da maior premiação brasileira de quadrinhos, Troféu HQ Mix, na categoria "Jornalista especializado" - nomeado de 2000 a 2006, consecutivamente, até que a categoria foi extinta em 2007. Foi editor da área de quadrinhos em várias editoras (Conrad, Panini, Globo) e hoje é responsável também pela área de planejamento editorial da Mauricio de Sousa Produções.

Em resposta ao questionário (Apêndice F), Sidney explica que o letreiramento precisa da mesma atenção das demais etapas de produção de HQ, como colorização e produção de capa. Como editor, é seu dever compreender o nível de complexidade demandado por uma obra no que tange ao tratamento gráfico dos textos. Segundo Sidney, propõe-se o serviço de letreiristas em trabalhos onde personagens apresentam vozes particulares, trabalhos com o visual mais orgânico ou trabalhos traduzidos em que o autor tenha conferido muito de sua personalidade na grafia textual. O exemplo citado pelo editor é a Zap Comix, traduzida e lançada pela editora Conrad em 2003, na qual Sidney Gusman foi incumbido da preparação do projeto.

Figura 121. Versão original e versão traduzida de Zap Comix
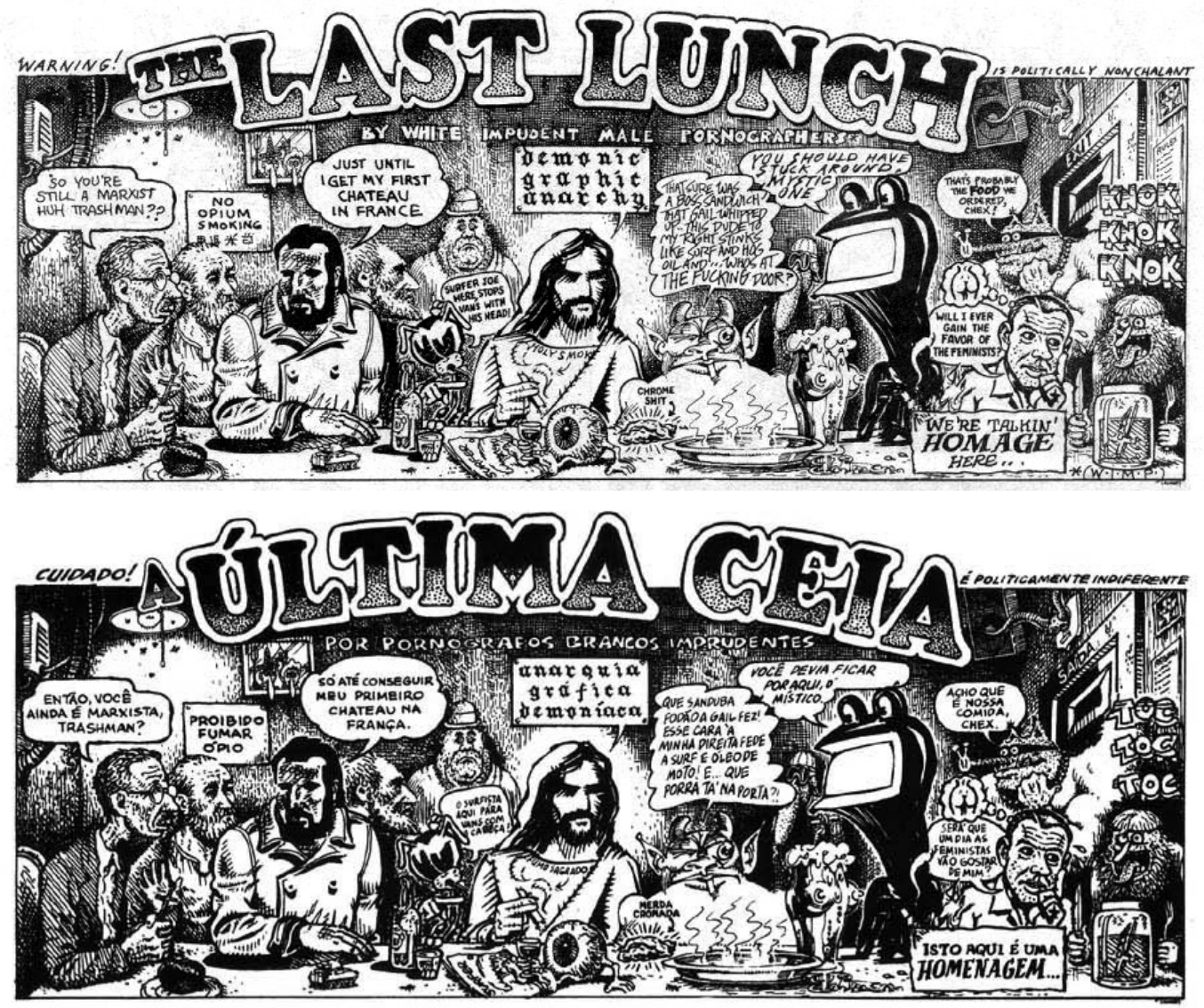

Fonte: CRUMB, 1994, p. 3 e CRUMB, 2005, p. 174 (letreiramento por Lilian Mitsunaga) 
A revista (Figura 121) é uma compilação de histórias de diferentes autorias, cada uma letreirada à mão por seu respectivo criador, com foco em temas da contracultura como constestação às normas rígidas impostas pela Comics Code Authority. Como a escrita incorporava valores da expressão individual e contribuía para o visual despojado da ilustração, os textos não poderiam ser trabalhados por alguém inexperiente, então, Lilian Mitsunaga foi escolhida para reproduzir o estilo original.

Caso o editor julgue que o estilo de letra não possui interferência significativa na percepção da arte e da história, normalmente o próprio autor da obra se torna encarregado da inserção de texto ou a tarefa é passada para profissionais sem especialização em letreiramento.

A segunda solução mencionada é comumente aplicada em mangás traduzidos. Os textos originais são usualmente incluídos pelo computador, utilizando fontes similares às utilizadas em jornais e revistas, ou seja, sem o cuidado de se assemelharem a uma escrita à caneta. As onomatopeias mais elaboradas e desenhadas pelo autor costumam ser mantidas intactas com uma nota de tradução na versão brasileira. Por esses motivos, as editoras desobrigam o responsável pela substituição dos textos de ter conhecimento aprofundado no assunto.

Para obter respaldo sobre essa dedução, a editora JBC, considerada a maior editora brasileira de mangás, foi questionada sobre os pré-requisitos e a capacitação para a função de letreirista. A resposta recebida ${ }^{47}$ foi:

As pessoas que trabalham com os textos nos quadrinhos geralmente são formadas em design e adjacências, ou formadas em letras. Não há nenhum treinamento específico para a atividade.

(Equipe JBC, 2013)

Mesmo assim, coleções publicadas com maior qualidade, isto é, com maior número de páginas, imagens coloridas e com papel de nível superior, normalmente contam com o serviço de profissionais especializados. Foi o caso, por exemplo, do título Sailor Moon, letreirado pela Lilian Mitsunaga para a JBC.

Ao trabalhar com obras importadas, o fato de os balões e demais suportes já estarem prontos pode representar uma facilidade, mas também pode virar um problema se a tradução se tornar mais longa que a frase original. Sidney diz que uma saída consiste em enxugar o texto para caber no balão, mas afirma que essa complicação de não é muito recorrente.

Sidney ocupa também o posto de editor-chefe do Universo HQ, considerado o principal site brasileiro sobre quadrinhos, vencedor nove vezes do Troféu HQ Mix em sua categoria (de 2000 a 2007 e em 2009). O portal já publicou artigos com análises detalhadas sobre letreiramento, como a matéria "Asilo Arkham - Uma Séria Casa em um Sério Mundo - Edição Definitiva", escrita por Liber Paz em 2013.

$47 \quad$ O contato foi estabelecido por e-mail no dia 10 de junho de 2013 e a resposta foi recebida um dia depois. 
O site apresenta também uma coluna em que são eleitos os melhores e os piores quadrinhos publicados no mês ou no ano, segundo cada membro da equipe. Perguntado se Sidney leva em consideração aspectos gráficos do texto ao fazer sua seleção, o editor respondeu que não; no entanto, quando ele escreve uma matéria sobre um trabalho cujo letreiramento chama a atenção - de maneira positiva ou negativa, Sidney faz questão de mencionar o assunto.

\section{LETREIRAMENTO EFICIENTE X LETREIRAMENTO AMADOR}

Para entender como os profissionais do letreiramento enxergam a importância de seu ofício, foram feitas perguntas sobre suas opiniões relacionadas à diferença entre um trabalho profissional e um trabalho amador, à contribuição do letreiramento para a história e aos aspectos que podem favorecer ou prejudicar a qualidade do serviço. As informações foram, então, analisadas e cruzadas.

Comparando o letreiramento ao uso de efeitos especiais cinematográficos, Troy Peteri explica que nos tornamos tão acostumados aos efeitos que se tornou difícil impressionar o público, mas o espectador nota rapidamente um gráfico de má qualidade ou um efeito sonoro impróprio, o que quebra o vínculo com a cena. De maneira similar, um letreiramento descuidado pode romper o ritmo da leitura e afetar a apreciação da arte - Todd Klein acrescenta a interferência na compreensão da história como uma consequência de um lettering amador. Nate Piekos faz um paralelo similar com a trilha sonora de filmes, lamentando-se que o amadorismo tenha maior impacto que o bom letreiramento: "Quando é benfeito, você mal nota (...) ele contagia o humor sem que você perceba esse efeito. Quando é ruim, você é desligado imediatamente da história. É o pior crime que um letreirista pode cometer" (tradução da autora).

Ron Marz corrobora com a teoria de que o letreiramento cuidadosamente executado passa despercebido pelos leitores quando respondeu sobre a recepção do público à mudança de estilos definida por Troy em Witchblade. O escritor colocou os poucos comentários recebidos como uma avaliação positiva, pois significa que o lettering integrou os leitores à história. A partir disso, infere-se que haveria maior repercussão se o resultado fosse o deslocamento apontado por Nate como a maior fatalidade do segmento.

Ainda de acordo com Nate e conforme foi visto no capítulo 3 deste trabalho, as histórias em quadrinhos possuem suas próprias regras gramaticais e de pontuação. O designer de fontes afirma que a incompetência se deve à desobediência dessas normas (Figura 122), seja por negligência, seja por ignorância. 
Figura 122. Cinco erros comuns cometidos por letreiristas amadores
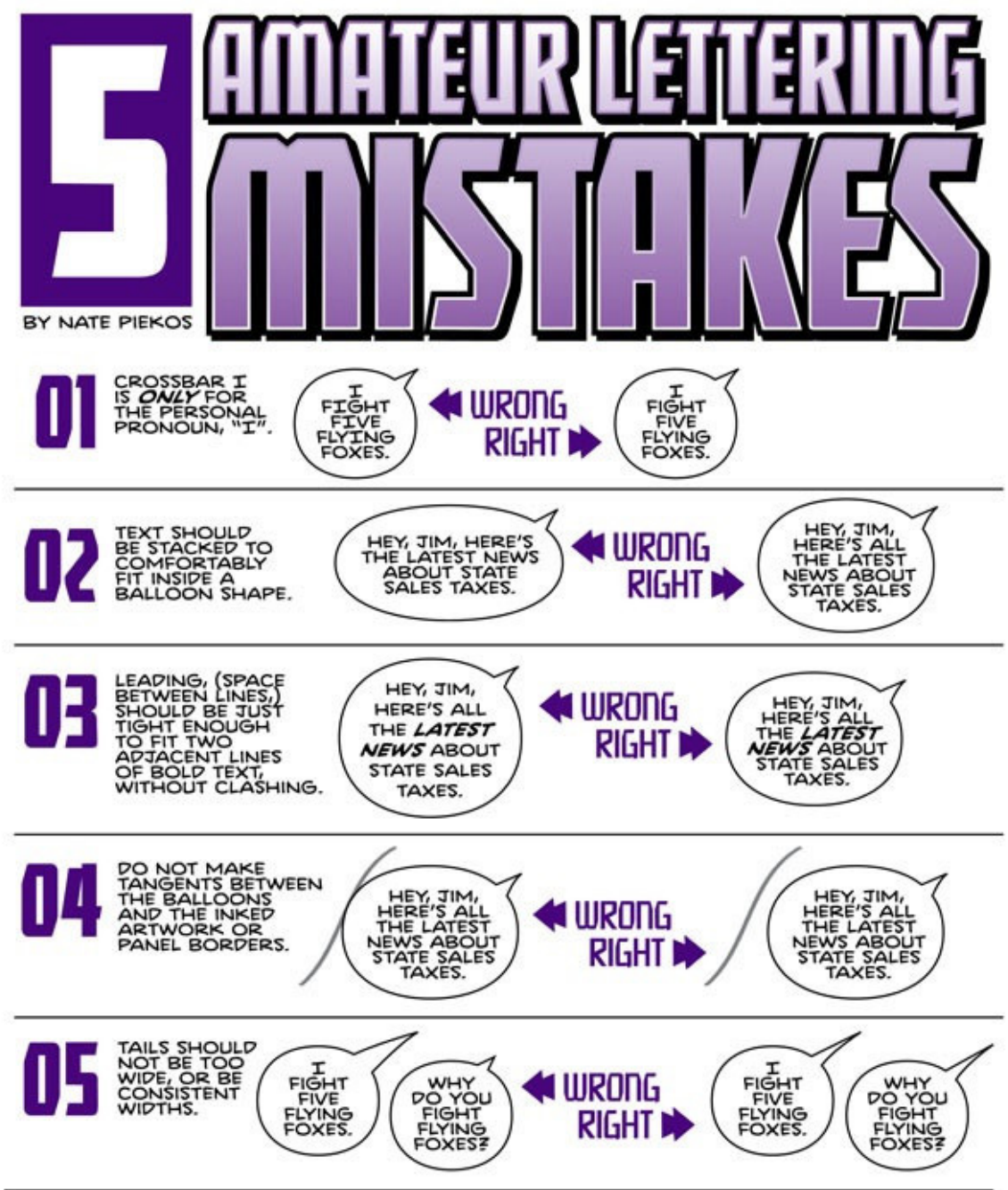

(9) NATE PIEKOS. BLAMBOT.COM. ALL RIGHTS RESERVED. FONTS USED, REVENGER BB AND HEAVY METTLE BB.

Fonte: @Nate Piekos, 2012

Por outro lado, Troy acredita que a diferença entre o bom letreiramento e o ruim é mais sutil. Segundo ele, a impressão de amadorismo pode ser passada pelo posicionamento desleixado dos balões que não leva em conta a ilustração ou o fluxo de palavras; pela aparição de vários balões que pareçam ser cópias de um mesmo modelo, sem qualquer individualidade; e/ou por escolhas precárias de fontes genéricas.

Já o bom letreiramento orienta o olhar do leitor pela página de forma rápida e fácil, sem que haja qualquer confusão. Para atingir esse patamar, alguns elementos citados por Troy são o uso de balões e fontes interessantes que combinem com o tema da obra. Sidney, por outro lado, fala sobre as qualidades procuradas em um letreirista para ter a garantia de um bom trabalho: cuidado, atenção e criatividade. Esses atributos somados à proatividade podem colaborar para a fluidez da história. Nate também considera que o grande diferencial reside no profissional e não na sua forma de execução: o que distingue um bom letreirista é a paixão pelo design gráfico, e isso, junto a um olhar experiente, desponta para o melhor nível de letreiramento possível. 
É possível contar uma história sem o uso de palavras, mas Nate defende que o letreiramento acrescenta um sistema mais conciso de informações a serem veiculadas ao leitor. Essa é a principal contribuição apontada por Todd Klein do letreiramento para a HQ, com ênfase na transmissão das palavras do escritor. Para Troy, o trabalho do letreirista é servir não apenas ao escritor, como também ao artista e ao leitor, tendo como ferramentas a colocação do texto e o processo de seleção dos recursos visuais disponíveis. Tais recursos, de acordo com Lilian, são eficientes para induzir a sensação sonora, onde a imaginação do leitor se incumbe de trazer o som às cenas.

LETREIRAMENTO MANUAL X LETREIRAMENTO DIGITAL

O uso do computador é a prática dominante no mercado atual, mas o embate entre letreiramento manual e letreiramento digital permanece. Com base nas respostas aos questionários e informações de profissionais coletadas em outras fontes, serão apresentados os argumentos utilizados para defender cada lado do debate, de forma imparcial.

O letreiramento manual ${ }^{48}$, quando feito pelo próprio ilustrador, permite maior controle para harmonizar o texto à arte e concede maior individualidade e unidade à composição como um todo. É também um processo que combina com a forma artesanal de fazer quadrinhos, já que o desenho e a arte-final são feitos à mão. Para o cartunista e designer gráfico Morris (2012), autor de The League of Regrettable Superheroes, as letras não são escritas, e sim desenhadas por serem parte da expressão visual do criador; por consequência, letreiramento e arte não deveriam ser dissociados na forma de produção. Piccolo (2012), criadora da webcomic Tina's Groove, acha que as letras feitas à mão dão um toque pessoal e mais humano às HQs, o que as torna mais amigáveis ao olhar.

No entanto, exige-se que o feitor possua uma caligrafia facilmente legível e agradável visualmente. Caso contrário, o ritmo da leitura e a compreensão da história ficam comprometidos. A terceirização do processo desqualifica o argumento da marca característica do autor, mas mantém o fator organicidade e humanidade. Em contraposição, Troy ratifica que é possível replicar o letreiramento manual no computador. Além do uso de modulação de traço nos balões e nos caracteres, outra prática comum para esse fim é o desenvolvimento de mais de uma opção para a mesma letra e a geração de ligaduras nas fontes Opentype.

Outro ponto negativo do uso de canetas e penas, segundo Lilian Mitsunaga em entrevista (abr. 2015), é a formação de calos e manchas de tintas nas mãos. $O$

$48 \quad$ Richard Starkings defende que as mãos também são usadas no letreiramento digital e, portanto, o oposto deveria ser "letreiramento à caneta". Para este trabalho, no entanto, optou-se pela terminologia mais usual. 
letreiramento eletrônico elimina esses incovenientes e é considerado mais limpo não somente pela ausência do nanquim, como também por dispensar o uso de linhas-guia sobre a arte.

Para Nate Piekos, o advento do letreiramento digital representou simplesmente a aparição de um equipamento diferente para a realização da mesma tarefa, evento equiparado à distinção entre violão e guitarra elétrica. Lembrando que Nate considera o conhecimento em design gráfico como o divisor entre o profissionismo e a mediocridade, a principal diferença apontada por ele é a curva de aprendizado: enquanto letreiristas à mão geralmente desenvolvem um senso de design e um estilo individual antes de iniciarem a carreira, os letreiristas digital têm um período mais curto para desenvolverem essas mesmas sensibilidades.

Como foi visto no subcapítulo 2.5, Richard Starkings foi um dos pioneiros a letreirar usando fontes digitais. De acordo com ele ${ }^{49}$, um dos avanços obtidos foi a possibilidade de usar letras minúsculas, o que era outrora impensável devido às complicações das linhas-guia adicionais, da necessidade de um tamanho maior de texto e do cruzamento eventual de ascendentes e descendentes das letras. $\mathrm{O}$ computador também permitiu mais facilidade na redução do tamanho da fonte, onde não se corre o risco de haver vazamento de nanquim nos olhos dos caracteres. Contudo, o letreirista Ken Bruzenak (apud Klein ${ }^{50}$ ) receia que essa viabilidade tenha feito com que os textos tenham ficado cada vez menores e mais difíceis de ler, sem qualquer razão aparente. $O$ uso de minúsculas, então, torna-os em quase indecifráveis para serem lidos no papel, de forma que é preciso ampliar a página em aplicativos digitais de leitura, quebrando a composição geral e de quadros da narrativa.

Por outro lado, uma das vantagens mais citadas para a adoção de fontes eletrônicas é a praticidade na execução, o que faz com que a tarefa seja finalizada em menos tempo. Lilian explica que o uso de arquivos digitais evita o deslocamento físico para entregar e buscar as páginas, já que podem ser enviados por e-mail, servidores FTP e outras maneiras de transferências de dados. Troy Peteri complementa que esse método permite correções e edições mais rápidas, sem a necessidade de reescrever e redesenhar balões, como é preciso na técnica manual. Este benefício é replicado pela profissional brasileira replica que este benefício vira muitas vezes uma maldição, pois os outros responsáveis pela produção se aproveitam da facilidade e podem pedir alterações constantemente, até mesmo quando já houve aprovação para imprimir.

Evanier (1997) enumera como melhoria a consistência obtida pelo uso de fontes. Graças a isso, existe um padrão que pode ser seguido por qualquer letreirista que tenha as mesmas fontes, então, as páginas podem ser distribuídas por um número maior de letreiristas ou o profissional pode ser substituído sem que haja mudanças no visual da HQ. Infelizmente, outra perspectiva interpreta esse recurso de

$49 \quad$ Lettering Roundtable: the case regarding upper \& lower case lettering. Mesa redonda. Disponível em: <http://www.balloontales.com/articles/roundtable/>. Acesso em: jul. 2014.

50 KLEIN, T. The rise of digital lettering, part 7. Todd's Blog, 20 nov. 2014. Disponível em: <http://kleinletters.com/Blog/the-rise-of-digital-lettering-part-7-2/>. Acesso em: abr. 2015. 
maneira negativa, como uma desvalorização das habilidades particulares dos letreiristas ou até como banalização do serviço em si.

Outras vantagens encontradas foram a redução de despesas e instrumentos, pois papéis, lápis e tintas são menos utilizados e há menor geração de resíduos. Contudo, como aponta Todd Klein ${ }^{51}$, os custos com material foram um obstáculo no início da era de letreiramento digital, quando os computadores eram dispendiosos assim como os softwares necessários. O letreirista relata que a demanda pelo procedimento manual foi diminuindo até que, no fim dos anos 2000, já era quase nula. Para se manterem no mercado, os profissionais precisavam aprender a lidar com os programas e a criar suas próprias fontes ou comprar fontes comerciais, aumentando o gasto total e eliminando o diferencial que tinham em seu trabalho à caneta. Essas mudanças causaram ressentimentos que perduram até hoje, visto que fizeram com que alguns letreiristas relutantes abandonassem a carreira.

No Brasil, conforme conta Lilian (abr. 2015), a novidade também intimidou, com ameaças de que os próprios editores seriam capazes de realizar o serviço e os letreiristas seriam exonerados. Então, Lilian comprou seu primeiro Mac em 1996 e já passou a se familiarizar com os programas, rapidamente sendo conquistada pelas comodidades encontradas. Como foi visto no exemplo da Figura 115, apesar do uso predominante de fontes, existem casos em que Lilian prefere escrever à mão, como os textos manuscritos, os textos em curvas aleatórias e os que possuem diversos tipos de tamanhos de caracteres na mesma frase.

As editoras logo sucumbiram ao método eletrônico devido à agilidade adquirida no processo de produção, pois a realização da etapa da inclusão textual sobre as páginas digitalizadas permite sua feitura ao mesmo tempo em que as ilustrações são finalizadas pelo artista:

(...) o artista que desenha e arte-finaliza sua própria obra pode simplesmente se sentar e trabalhar em seu próprio ritmo. Ele não precisa desenhar tudo à lápis, e aí esperar duas semanas para o letreirista terminar e devolver as páginas para a arte-final. Isso pode ser enormemente benéfico para alguns artistas. O falecido Doug Wildey, por exemplo, sentia que seu trabalho ficava vastamente melhor quando ele ilustrava e arte-finalizada em uma única etapa.

(EVANIER, 1997, tradução da autora)

Como a camada com letreiramento é normalmente mantida à parte da arte, tornou-se possível as editoras de outros países terem acesso às páginas sem baIões nem textos no idioma de origem. Por consequência, as traduções ficaram livres do limite imposto pelo tamanho do suporte desenhado previamente e os retoques na ilustração não são mais necessários. Em contrapartida, de acordo com Lilian, é

$51 \quad$ KLEIN, T. Computer Lettering. Todd's Blog, 8 jul. 2007. Disponível em: <http://kleinletters. com/ComputerLettering.html>. Acesso em: abr. 2015. 
adicionada uma nova etapa para o letreirista estrangeiro, referente ao desenho dos balões e das caixas narrativas. Todd ${ }^{52}$ coloca outras inconveniências resultantes desse processo para as outras partes da esfera das HQs, como, por exemplo, a dedicação a mais para artistas e arte-finalistas, que agora deviam compor a página inteira, não podendo mais contar com partes a serem cobertas por onomatopeias ou suportes. A venda das páginas originais também foi afetada, agora que elas continham apenas a ilustração, pois a história fica desfalcada com a ausência do texto.

Outro benefício muito mencionado e também questionado é que o letreiramento digital oferece uma grande variedade de estilos, dado a existência de várias fontes comerciais. Estas são facilmente obtidas, instaladas e adaptadas às necessidades da obra. A consequência disso é que inserir textos de qualidade visual aceitável passou a ter menos pré-requisitos. Nate Piekos enfatiza que agora quase todo mundo pode comprar uma fonte e letreirar uma obra, já que o ofício deixou de demandar um alto nível de criatividade. Sidney Gusman acredita que, devido à expansão do letreiramento eletrônico, muitas editoras reduziram suas exigências na contratação do responsável pelos textos e isso tem obstruído a evolução do letreiramento no Brasil. Segundo o editor, essa estagnação é o principal motivo de o lettering ter sido categoria apenas uma vez na principal premiação brasileira de quadrinhos, a HQ Mix, em 1999.

$52 \quad$ KLEIN, T. The rise of digital lettering, part 7. Todd's Blog, 20 nov. 2014. Disponível em: <http://kleinletters.com/Blog/the-rise-of-digital-lettering-part-7-2/>. Acesso em: abr. 2015. 

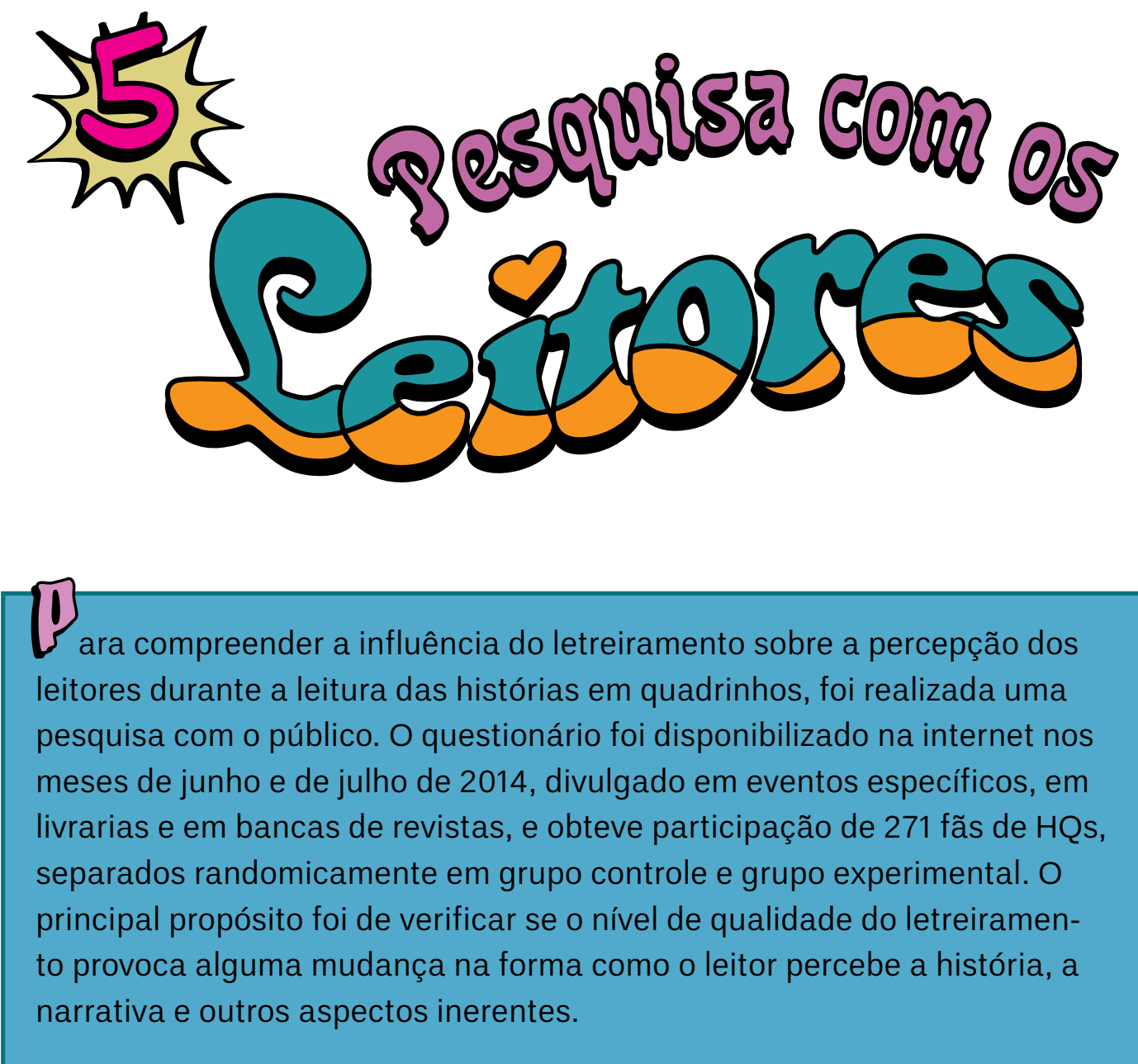

Foi visto no capítulo 3 que a inclusão do texto nas páginas das HQs, apesar de não possuir um padrão oficial, apresenta princípios para melhor aparência visual, otimização do espaço e uniformidade do estilo. Já no capítulo anterior, alguns profissionais atuantes do segmento afirmaram que o letreiramento é percebido principalmente quando há uma fuga eminente a esses preceitos, devido ao incômodo causado no momento da leitura. E quando as infrações são leves, como é a reação? A disposição e a forma das letras causa diferenças na percepção do leitor, mesmo que este não tenha consciência disso?

A fim de averiguar a existência de qualquer disparidade na maneira como é compreendida a obra, segundo o grau de qualidade do letreiramento, elaborou-se um questionário para o público de fãs de histórias em quadrinhos. Optou-se por executar um estudo de controle, o qual permite comparar os dados obtidos para níveis técnicos diferentes. O método consiste na divisão de grupos de participantes, em que um deles é exposto à variável investigada (grupo experimental) e o outro, não (grupo controle). Em seguida, os resultados são comparados e são feitas inferências a respeito da relação entre os dados e o objeto de estudo. 
O propósito do estudo é manipular uma variável para verificar a relação entre causa e efeito, portanto, a pesquisa é considerada como experimental (Kerlinger, 1979). A variável independente abordada é a qualidade do letreiramento, classificada como variável qualitativa nominal, a qual foi dividida nas categorias:

- Bom letreiramento: segue os princípios adotados pelos profissionais experientes;

- Letreiramento aceitável: comete faltas leves, ou seja, erros comuns que não comprometem a leiturabilidade do texto nem a composição da página.

Para representar cada um dos tipos, optou-se por criar duas versões correspondentes para uma mesma história em quadrinhos. Duas páginas introdutórias de uma história fictícia tiveram seu enredo escrito pelo colaborador André Reis e foram revisadas por Vinícius de Azevedo. O roteirista recebeu a orientação de incluir diálogo, barulhos, placas e variações tonais, como berros e sussurros.

Depois disso, as ilustrações foram criadas por Rafael Benjamin, que foi instruído a não inserir os textos nas páginas. Os desenhos foram preenchidos em escala de cinza, para reduzir a interferência do fator cor.

Para a versão do grupo controle, ou seja, o grupo que seria exposto ao letreiramento de qualificação mediana, alguns erros amadores foram propositalmente aplicados. Essas faltas, no entanto, não poderiam se sobressair a ponto de chamarem a atenção ao letreiramento. A intenção foi de manter a "invisibilidade" da etapa para que os respondentes não soubessem qual o verdadeiro objeto de estudo e para compreender as influências que passam despercebidas pelos leitores.

Os deslizes utilizados foram os seguintes:

- Alterações dos tamanhos de fonte para um mesmo tipo de texto;

- O uso da letra "i" serifada no meio de palavras;

- Balões replicados: Troy aconselha a tratar os balões individualmente, sem deixar óbvio o copia-e-cola;

- Cruzamento de rabichos e rabichos demasiadamente compridos;

- Uso de fontes genéricas;

- Uso da mesma fonte para diferentes tipos de texto;

- Centralização inadequada do texto no suporte;

- Quebra do texto sem levar em conta o formato do balão;

- Estilo de letra não condizente com a arte.

O resultado se encontra na Figura 123 e na Figura 124. 
Figura 123. Primeira página do tipo controle.
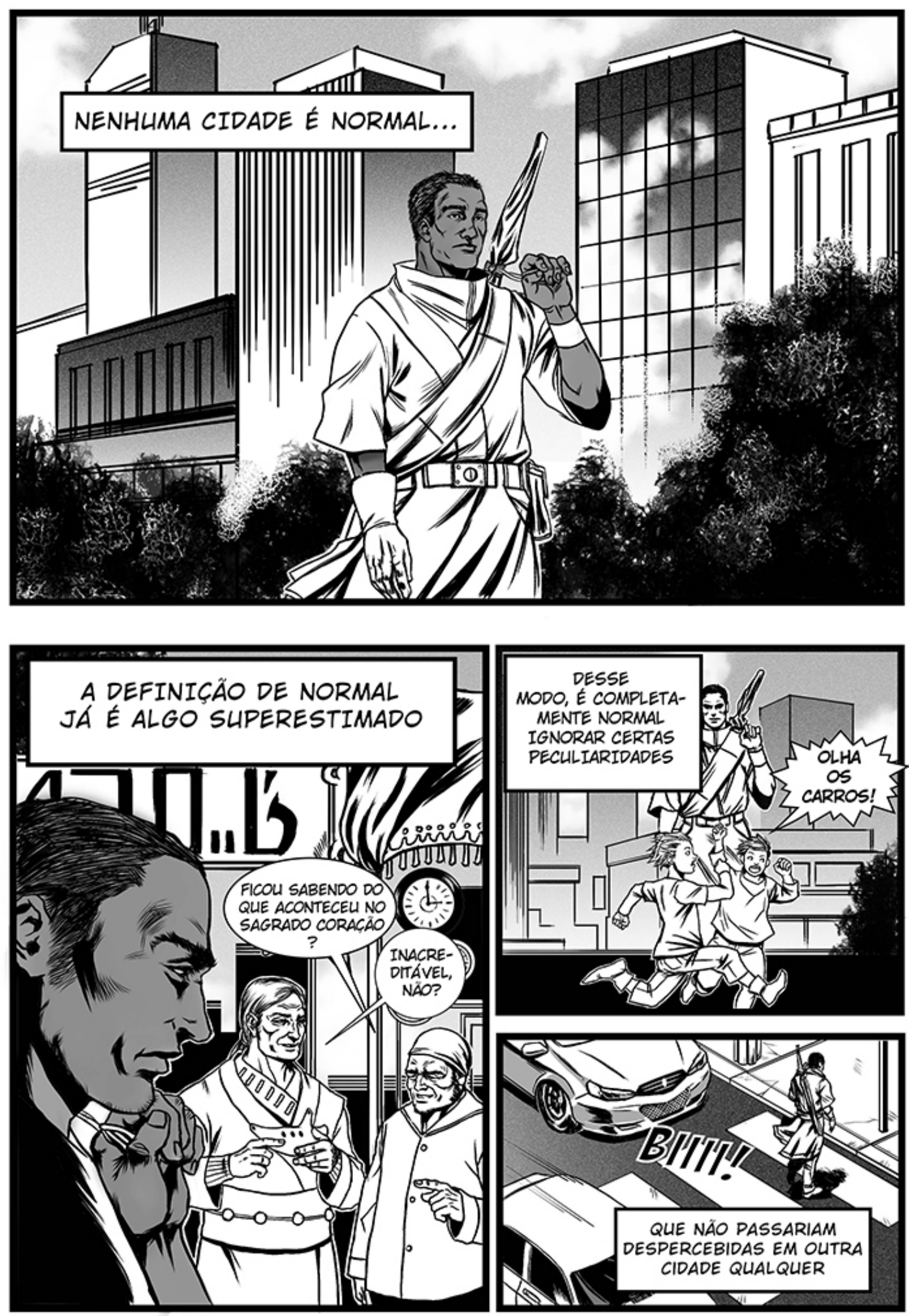
Figura 124. Segunda página do tipo controle.
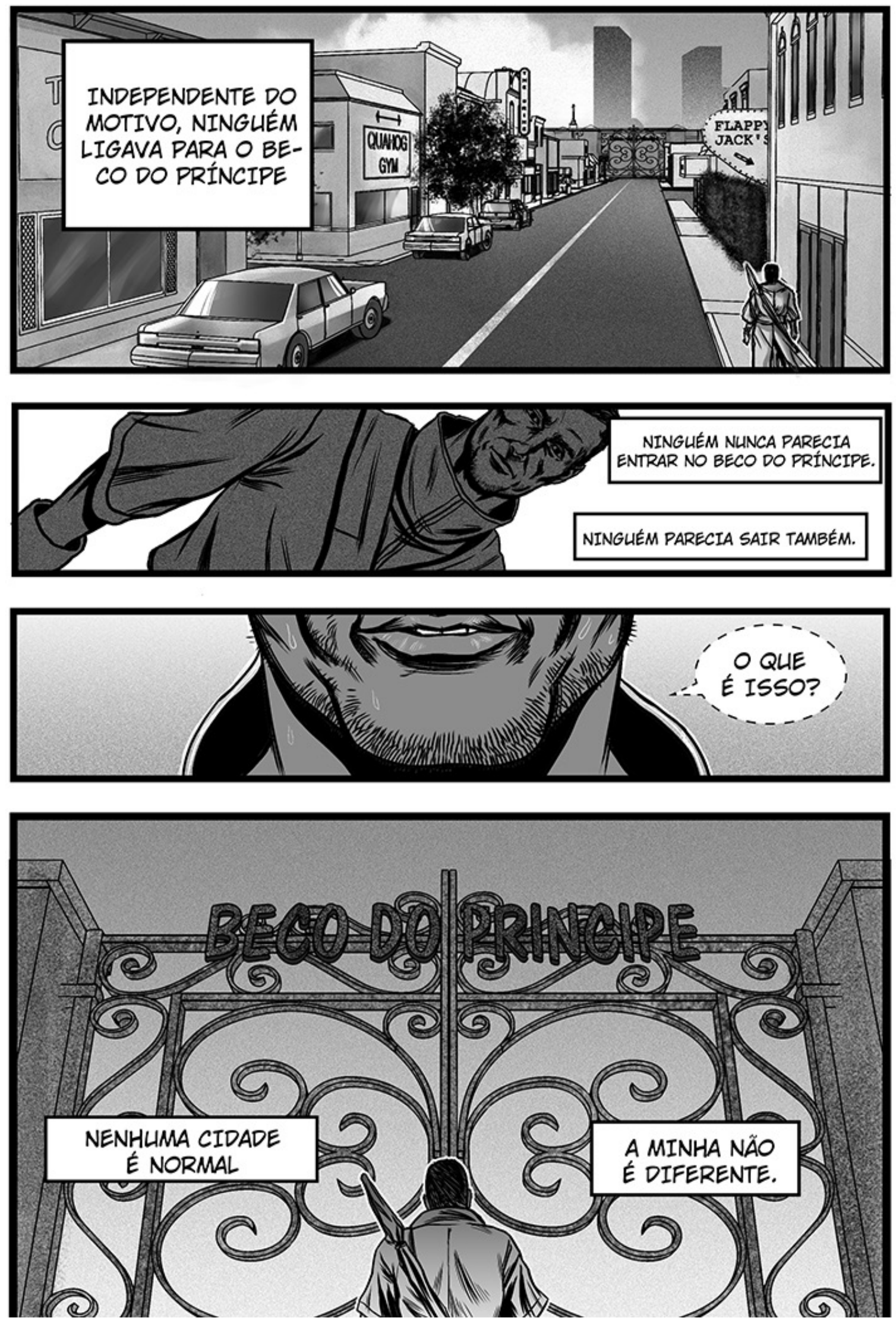

Fonte: da autora 
Para o tipo experimental, buscou-se seguir as dicas de formatação e de escoIha de fontes. Os textos foram centralizados corretamente nos balões e a mancha gráfica seguiu os moldes do suporte - em formato ovalado, como recomendam Klein (2004, p. 91), Oatley (jul. 2012) e Lainé e Delzant (2010, p. 10).

Quanto à narração em primeira pessoa, o estilo de letra foi diferenciado da fonte padrão, Wild Words Roman, a mesma utilizada em quase todos os textos do tipo controle. A distinção serve para fortalecer a individualidade do personagem principal, portanto, a seleção da fonte teve como critério a coerência com traços da personalidade do protagonista.

Optou-se pelo estilo caligráfico para reforçar a ideia de unicidade, pois a narração, assim como sua forma de escrita, são atributos particulares do personagem. Para aumentar a conexão entre ambas, foram buscadas as principais características de sua personalidade e estas foram ligadas a princípios da grafologia. Embora seja considerada uma pseudociência, a grafologia é o único estudo que busca a correlação entre personalidade e caligrafia.

Pelo uso correto da gramática e pelos termos rebuscados que ele utiliza, infere-se que seja um homem adulto letrado. Depreende-se também que suas emoções são moderadas e que trata-se de uma pessoa contemplativa, introvertida, observadora e curiosa. A seleção foi feita de acordo com Amend e Ruiz (1980), que dizem que: letras pequenas são normalmente utilizadas por pessoas reclusivas e concentradas; espessura média do traçado indica controle emocional; letras sem inclinação são indícios de pessoas analíticas e cautelosas; formas de letras mais simples, sem ornamentos ou descuidos, são sinais de maturidade e praticidade; letras não conectadas entre si indicam independência, individualismo e confiança no próprio instinto, e; ascendentes e descendentes de tamanho mediano são ligados ao equilíbrio interno. A partir dessas informações, foi escolhida a fonte Clairvoyant, da empresa Blambot.

Figura 125. Fonte Clairvoyant, escolhida para as narrações em primeira pessoa.

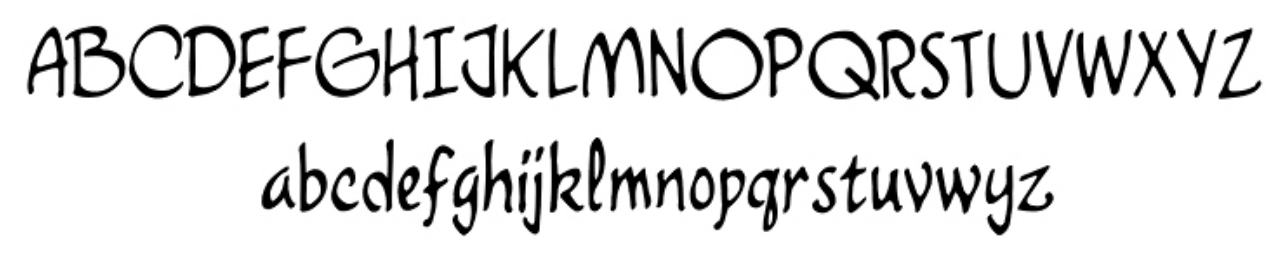

Fonte: da autora

Os balões foram feitos individualmente com traço modulado para simular a feitura à caneta. A onomatopeia foi inserida com tamanho de letra e posicionamento irregulares para destacar a inconstância sonora do barulho. O sussurro do protagonista na segunda página é representado com letras minúsculas em vez do usual balão com bordas tracejadas.

O resultado se encontra na Figura 126 e na Figura 127. 
Figura 126. Primeira página do tipo experimental.
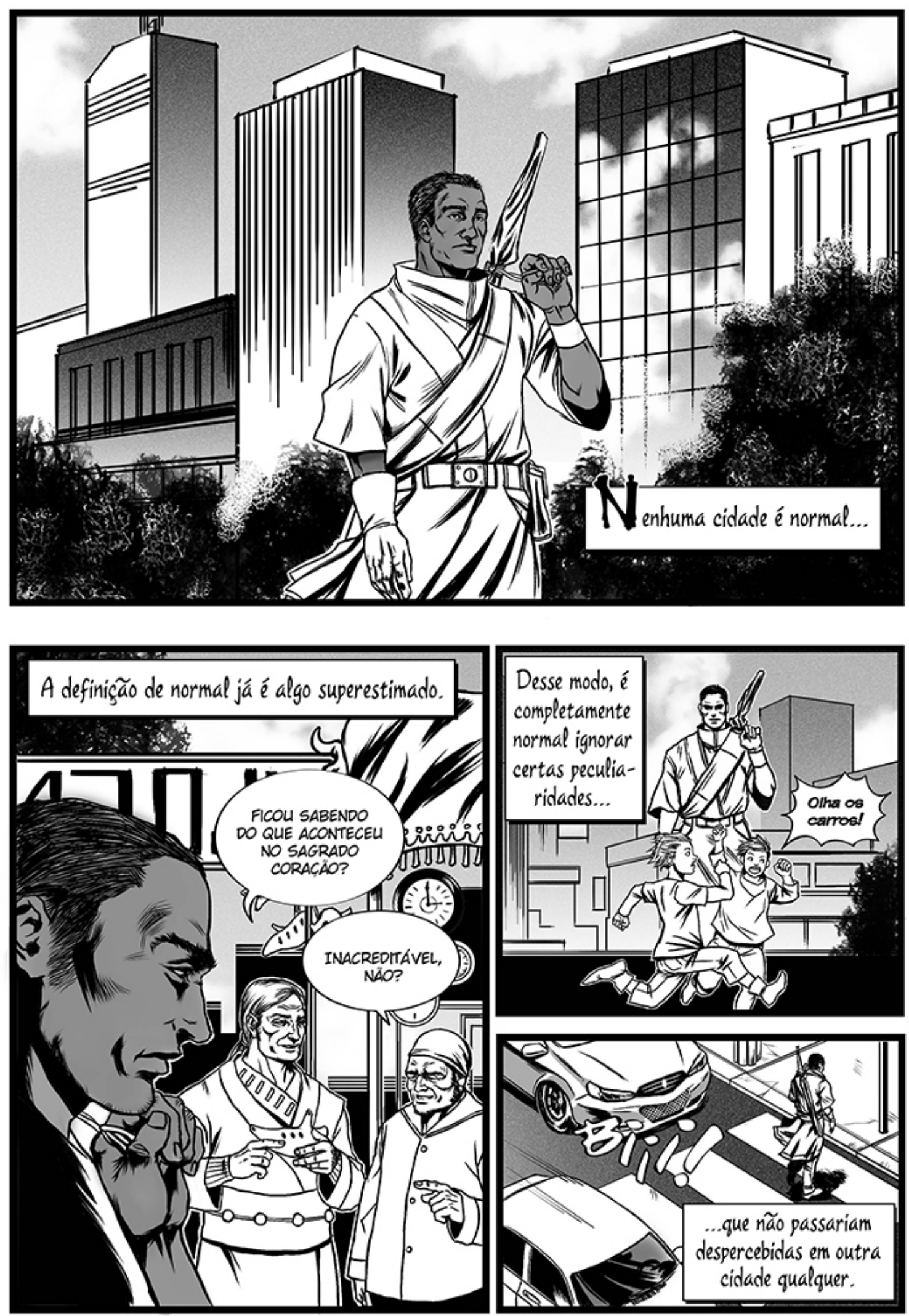
Figura 127. Segunda página do tipo experimental.
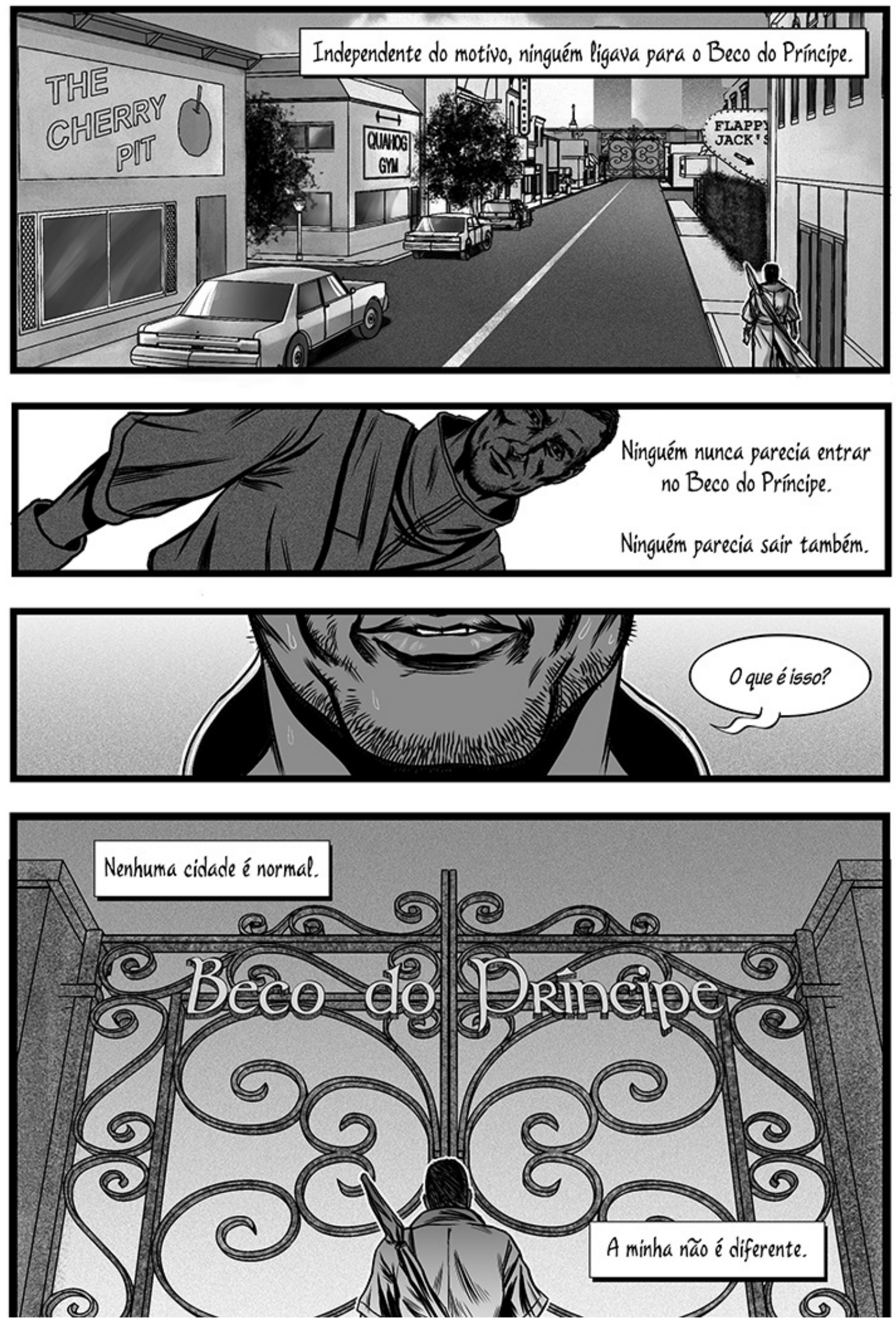

Fonte: da autora 
A plataforma online foi escolhida por ser mais prática, pois o questionário pode ser aberto em dispositivos diferentes (computador pessoal, smartphone, tablet) e, assim, vários participantes podem respondê-lo ao mesmo tempo, no momento e no local que julgarem mais convenientes.

Os itens a serem avaliados foram atributos que poderiam mudar na percepção do leitor conforme a qualidade do letreiramento. Buscou-se saber se a variável estudada influencia, em algum grau:

- a vontade do leitor de prosseguir com a leitura;

- a agradabilidade da leitura;

- a forma como o leitor percebe o protagonista;

- a leiturabilidade do texto;

- a clareza da história;

- a percepção do ritmo da narrativa.

Com essa proposta de pesquisa, foi utilizada a escala Likert, onde o participante deveria selecionar um dentre cinco diferentes graus de concordância a respeito de uma afirmação. Para evitar que o participante marque uma opção aleatoriamente no caso de dúvida, foi acrescentado também "Não sei responder".

Como o gosto pelo gênero poderia interferir nas respostas, no sentido de que os participantes que não gostam de suspense tenderiam a dar mais respostas negativas, a afirmação "Eu curto esse gênero de HQ" foi adicionada para que eventuais distorções pudessem ser analisadas.

Por fins éticos, a página inicial do questionário pedia que os participantes tivessem mais de 18 anos, mesmo que nenhum risco tenha sido identificado. No mesmo texto, foram colocados a identificação e os dados de contato da pesquisadora com uma breve explicação da pesquisa, onde era dito o tempo médio de resposta (quatro a sete minutos) e a composição do questionário. O objetivo foi descrito como "investigar a interferência de determinados aspectos visuais sobre a qualidade de leitura de histórias em quadrinhos." Não ficava explícito que o letreiramento era a variável estudada, pois a intenção era de que os respondentes não soubessem o que estava sendo avaliado.

Foi explicado também que a participação era voluntária e que quaisquer dados que permitissem identificar o participante seriam de absoluto sigilo. Por fim, ficava esclarecido que, ao prosseguir, o respondente concordava com o termo de consentimento lido.

Em seguida, o participante era randomicamente exposto ao tipo controle ou ao tipo experimental das duas páginas de quadrinhos. Após o término da leitura, aparecia a mesma questão (Figura 128) para os dois tipos, configurada para apresentar as afirmações em ordem aleatória. 
Figura 128. Questão formulada para a pesquisa.

Seguem abaixo algumas afirmações sobre a história em quadrinhos que você acabou de ler. Marque a opção que melhor representa sua opinião acerca de cada uma:

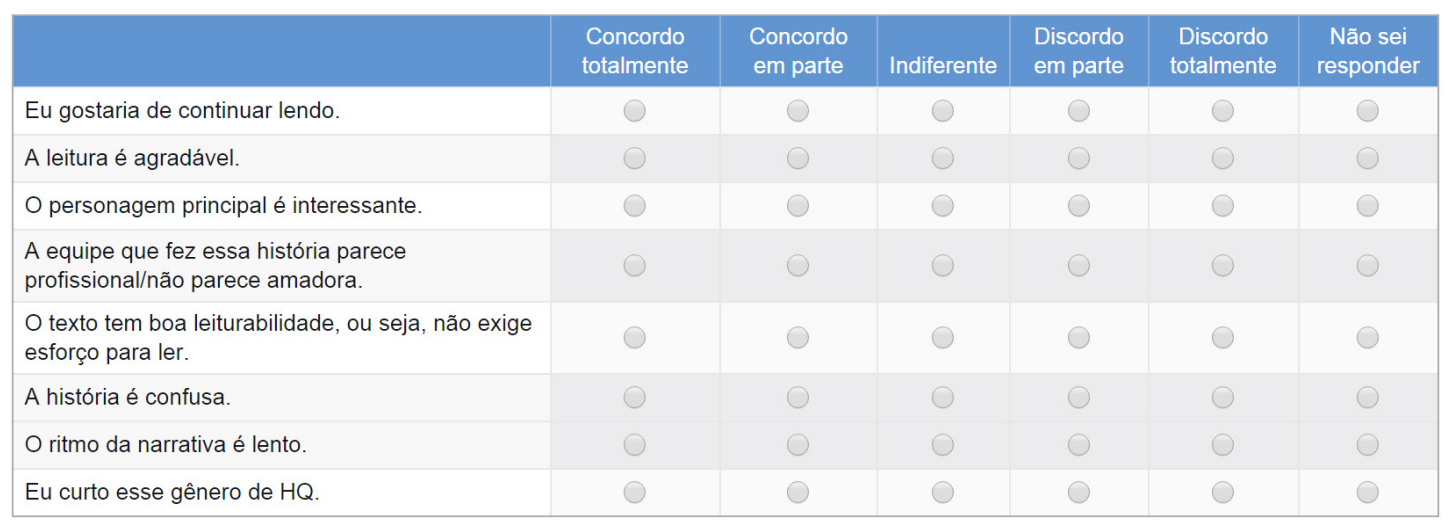

Fonte: da autora

O público-alvo foi definido como leitores de histórias em quadrinhos, para minimizar os efeitos da variável "gosto por HQs". Por consequência, os locais de divulgação do questionário foram selecionados segundo a probabilidade de encontrar pessoas desse nicho, como livrarias, bancas de revistas e pontos com a temática geek $^{53}$ (eventos, lojas e grupos de redes sociais).

Observando os grupos de quadrinhos do Distrito Federal, constatou-se um interesse por marcadores de páginas, que são brindes de algumas editoras. Então, decidiu-se criar marcadores com o convite para colaborar com o projeto, já que as peças impressas agilizariam a abordagem.

O design (Figura 129) foi concebido com base no estilo das histórias em quadrinhos, com direito a caixas narrativas e balões. Para torná-lo mais atrativo e reduzir as chances de descarte, foi adotado o modelo magnético, que é dobrável e possui manta magnética nos dois lados internos.

Uma breve explicação do trabalho foi inserida na área interna do marcador, e o endereço reduzido do questionário foi exposto no verso, seguido do endereço de e-mail para contato. A parte que fica visível após o encaixe do marcador no livro continha uma chamada para despertar a curiosidade de quem visse: "Gosta de quadrinhos?". Buscou-se deixar o lado frontal bem vistoso, com uma onomatopeia em pop art, de forma a distingui-lo de um cartão de visitas.

Foram impressas mil peças, das quais 700 foram distribuídas em dois eventos, que ocorreram em maio e em junho de 2014 na cidade de Brasília, e 300 foram disponibilizadas na seção de quadrinhos em livrarias e em bancas de revistas, com permissão dos proprietários das lojas.

O questionário, que ficou disponível por dois meses, foi divulgado também em grupos de discussão, compra e venda de quadrinhos, de redes sociais.

53 Geek ['gi:k] é uma gíria inglesa relacionada a pessoas interessadas em tecnologia, eletrônica, filmes de ficção científica, séries, animes e histórias em quadinhos. 
Figura 129. Frente e verso do marcador de páginas

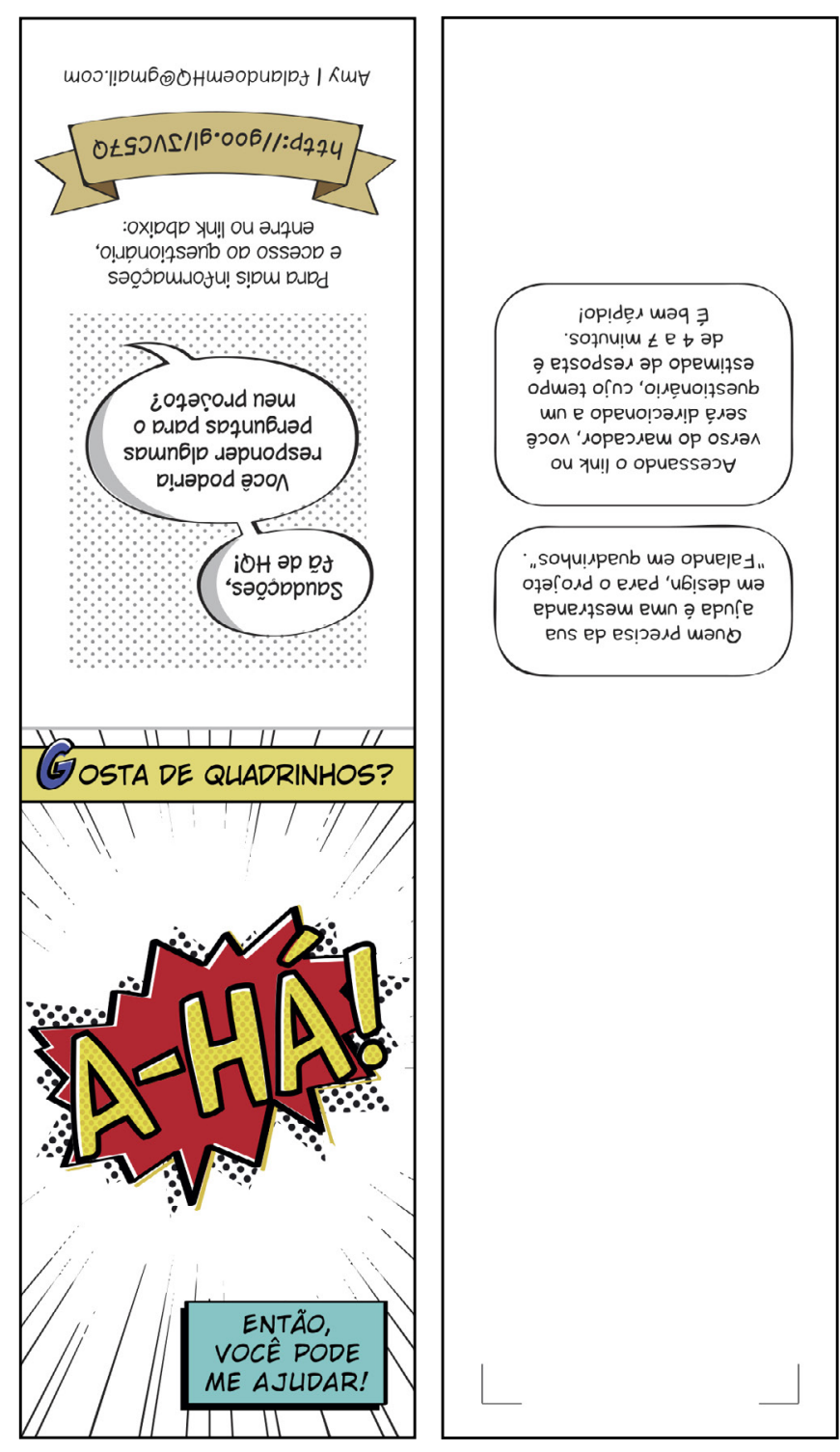

Fonte: da autora

Figura 130. Marcadores impressos

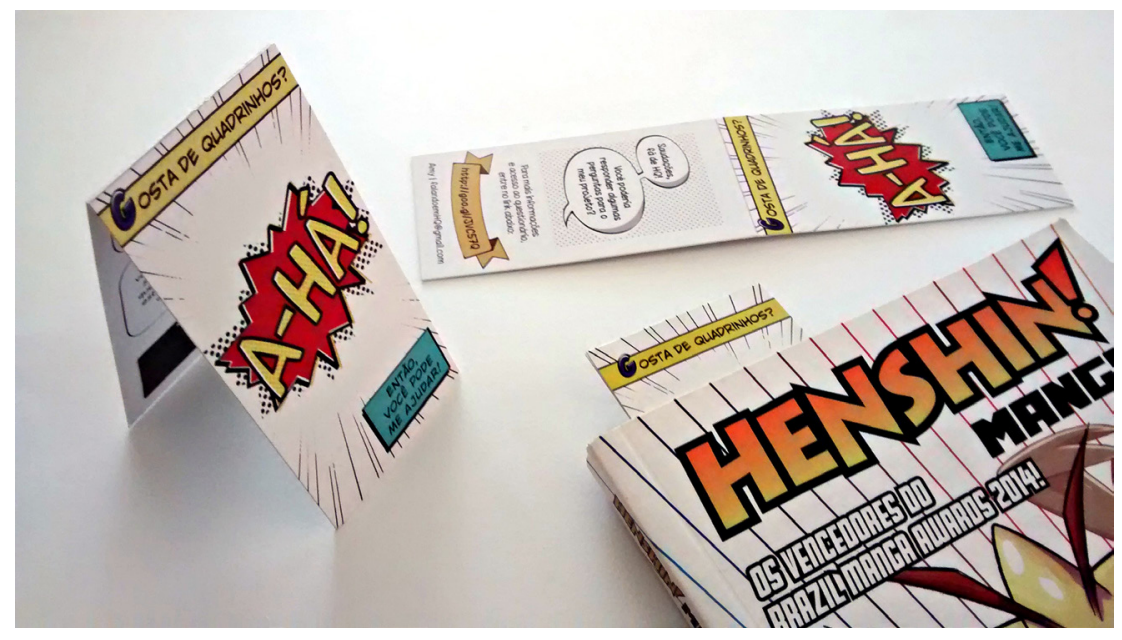

Fonte: da autora 
O questionário foi fechado no início de agosto de 2014, com o total de 271 respostas - 144 para o tipo experimental e 127 para o tipo controle. Considerando que mil marcadores tenham sido distribuídos, a eficácia da estratégia de abordagem foi inferior a 30\%. Após reavaliação do processo, alguns motivos foram levantados para o elevado número de não-respostas.

A quantidade de acessos ao endereço foi de 397, o que significa que 126 pessoas entraram no questionário, mas não o completaram. As possíveis razões são: a limitação de idade para maiores de 18 anos e o layout utilizado, que não era responsivo para dispositivos móveis (não permitia fácil associação entre o grau de concordância e as opções de marcação).

Outra justificativa é que as mil peças não foram entregues para mil pessoas diferentes. Ao distribuir pessoalmente nos eventos, foram feitos vários pedidos por mais marcadores e, como cada convenção ocorreu em dois dias e as duas foram em Brasília, é muito provável que os mesmos frequentadores tenham sido abordados mais de uma vez em dias diferentes. Os lojistas confirmaram também que os clientes normalmente levavam mais de um marcador.

O principal motivo encontrado foi a diferenciação do endereço virtual reduzido entre letras maiúsculas e minúsculas, sendo que a digitação inteiramente em caracteres minúsculos encaminhava para uma página inexistente. Imagina-se que boa parte dos prospectados não conseguiram acessar o questionário, e isso é ratificado pelos sete contatos recebidos questionando se a pesquisa já havia sido finalizada, pois parecia bloqueada.

Mesmo assim, a quantidade de respostas foi suficiente para realizar uma análise descritiva e testes de correlação. Devido à aplicação do amadorismo do tipo controle sobre detalhes de pouca relevância para a história, a diferença esperada entre os dois grupos era pequena, causando uma associação fraca a moderada.

Como foi dito anteriormente, a variável "preferência pelo gênero" não foi neutralizada, de forma que o gosto pessoal poderia interferir nas respostas. O ideal seria que as proporções de respostas fossem as mesmas nos dois tipos de questionário para a afirmação "Eu curto esse gênero de HQs". No entanto, os resultados revelaram que o grupo controle possuía $64,6 \%$ concordando em algum grau com a assertiva, contra $56,2 \%$ do grupo experimental. A aversão ao gênero teve uma diferença menor, representando $12,5 \%$ dos respondentes do tipo experimental e $9,4 \%$ do tipo controle. Ou seja, os participantes que leram as páginas com o letreiramento amador apresentaram uma porcentagem maior de fãs de suspense e menor de avessos, aumentando a probabilidade de ter respostas mais positivas. Esses dados foram analisados em conjunto com as outras afirmações, sendo que a maior interferência encontrada foi verificada em "Eu gostaria de continuar lendo". 


\subsubsection{Interesse pela continuidade da história}

Sem considerar a variável do gosto pessoal, a vontade de prosseguir com a leitura foi estudada conforme o tipo do grupo:

Tabela 1. Distribuição conjunta das proporções de participantes segundo o grupo e o grau de concordância para a afirmação "Eu gostaria de continuar lendo"

\begin{tabular}{l|r|c|c|c|c|c}
\hline Item & $\begin{array}{c}\text { Concordo } \\
\text { totalmente }\end{array}$ & $\begin{array}{c}\text { Concordo em } \\
\text { partes }\end{array}$ & Indiferente & $\begin{array}{c}\text { Discordo em } \\
\text { partes }\end{array}$ & $\begin{array}{c}\text { Discordo } \\
\text { totalmente }\end{array}$ & $\begin{array}{c}\text { Não sei res- } \\
\text { ponder }\end{array}$ \\
\hline Experimental & $47,92 \%$ & $34,72 \%$ & $9,72 \%$ & $6,25 \%$ & $1,39 \%$ & $0,00 \%$ \\
Controle & $48,03 \%$ & $21,26 \%$ & $10,24 \%$ & $10,24 \%$ & $10,24 \%$ & $0,00 \%$ \\
\hline Total & $47,97 \%$ & $28,41 \%$ & $9,96 \%$ & $8,12 \%$ & $5,54 \%$ & $0,00 \%$ \\
\hline
\end{tabular}

Fonte: da autora

Pela Tabela 1, é possível perceber que, em geral, os participantes concordaram mais do que discordaram sobre o interesse em ler mais páginas da história. Separando os grupos, verifica-se uma quase equivalência nas porcentagens para a concordância total e para a indiferença.

Gráfico 1. Gráfico comparativo para o grau de concordância referente à afirmação "Eu gostaria de continuar lendo" segundo o tipo do questionário

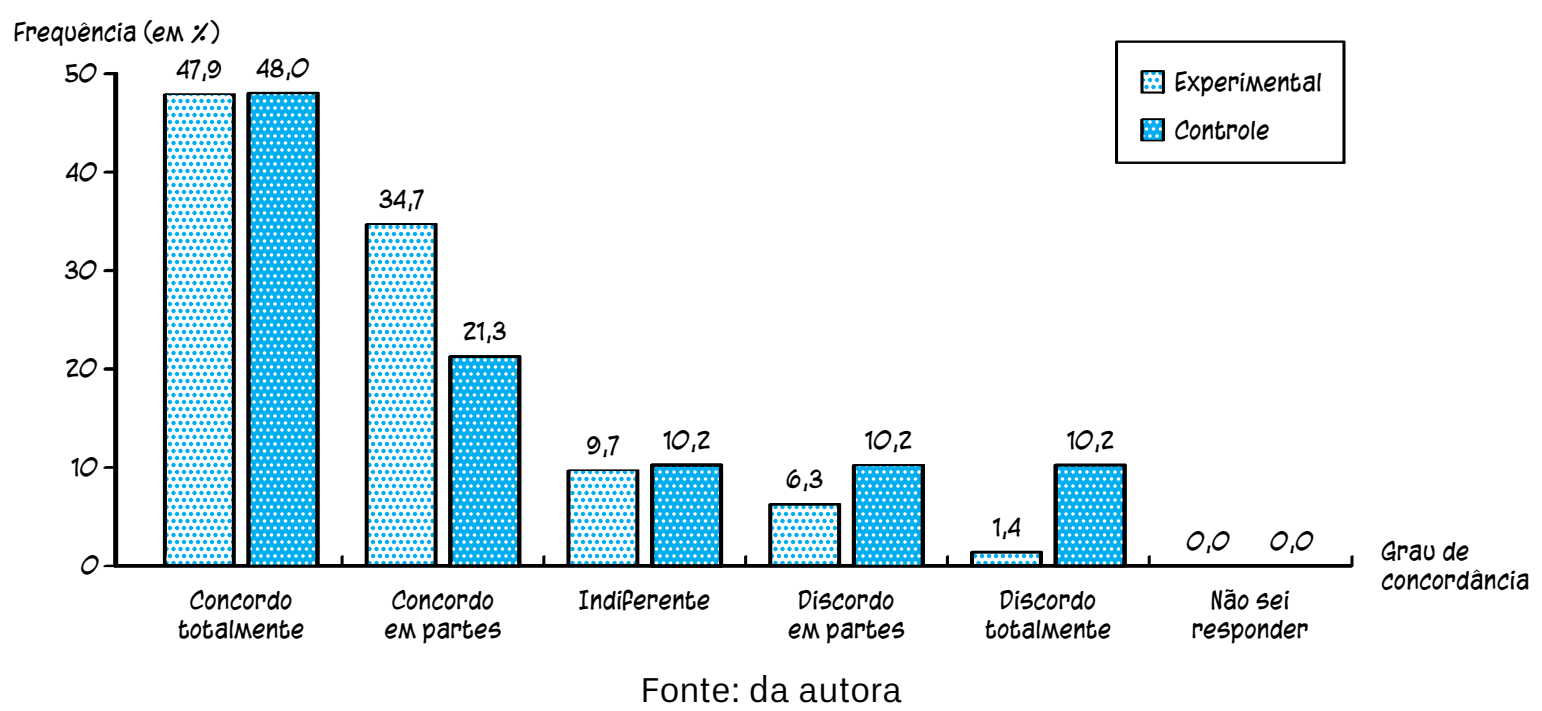

O gráfico correspondente mostra que a quantidade de votantes na concordância total é levemente maior para o tipo controle, no entanto, a discrepância se intensifica para a concordância parcial (desnível de 13,4 pontos) e se apresenta também nas discordâncias, de modo que a diferença chega a 8,8 pontos em "Discordo totalmente". Caso não houvesse qualquer associação entre o grau de concordância e qualidade do letreiramento, as colunas tenderiam a ter alturas mais próximas. 
Dada a diferença visível entre as barras de um mesmo grau, o grau de dependência entre as variáveis foi testado por medidas com base na distribuição $\chi^{2}$ (qui-quadrado), apropriadas para investigar variáveis qualitativas. Os dados foram simplificados em dois graus de concordância: "concorda" e "discorda ou é indiferente", ignorando a intensidade da concordância/discordância, os valores de "Não sei responder" e pressupondo a indiferença como negativa, já que significa que o item avaliado não se destacou de nenhuma maneira. Essa simplificação gera uma matriz $2 \times 2$, o que significa que as fórmulas para os coeficientes Phi $(\phi)$, T de Tschupov e $\mathrm{V}$ de Crámer se tornam equivalentes.

Tabela 2. Distribuição simplificada das proporções de participantes segundo o grupo e a concordância para a afirmação "Eu gostaria de continuar lendo"

\begin{tabular}{l|rr|c}
\hline \multirow{2}{*}{ Tipo de grupo } & \multicolumn{2}{|c|}{ Concordância } & \multirow{2}{*}{ Total } \\
\cline { 2 - 3 } & \multicolumn{1}{|c|}{ Concorda } & $\begin{array}{r}\text { Discorda ou } \\
\text { é indiferente }\end{array}$ & \\
\hline Experimental & $119(82,6 \%)$ & $25(17,4 \%)$ & $144(100,0 \%)$ \\
Controle & $88(69,3 \%)$ & $39(30,7 \%)$ & $127(100,0 \%)$ \\
\hline Total & $207(76,5 \%)$ & $61(22,5 \%)$ & $271(100,0 \%)$ \\
\hline
\end{tabular}

Fonte: da autora

As porcentagens totais da concordância, chamadas de totais marginais, representam os valores que os dois tipos de grupo deveriam assumir caso as variáveis fossem independentes. Por exemplo, se 110 pessoas do tipo experimental $(76,4 \%)$ e 96 pessoas do tipo controle $(76,4 \%)$ concordassem com a afirmação, as proporções estariam próximas do total marginal $(76,5 \%)$, indicando relação de independência. Não é a situação da tabela apresentada, então, havendo a chance de existir associação, foram calculadas algumas medidas.

O coeficiente de contingência de Pearson ( $\left.c^{\star}\right)$ é 0,21 , enquanto os coeficientes Phi $(\phi)$, T de Tschupov e V de Crámer são 0,16 . Os dois valores são abaixo de 0,3, portanto, indicam fraca associação entre a qualidade do letreiramento e a vontade de continuar lendo a história.

Realizando uma análise conjunta da afirmação "Eu gostaria de continuar lendo" com a variável "Eu curto esse gênero de HQ", obteve-se que $82 \%$ do grupo experimental que discordou do interesse na leitura discordou também do gosto pelo gênero, sendo que os outros $18 \%$ assinalaram indiferença. Já no grupo controle, $73 \%$ que discordaram querer continuar a leitura discordaram ou foram indiferentes quanto ao gosto pelo suspense. Ao executar o teste de correlação, obteve-se que a dependência entre as duas variáveis é forte, com o valor de 0,8.

Assim, pode-se notar que a variável gênero teve uma influência significativa nas respostas dos participantes nesse item, no sentido de que os avessos ao gênero tendem a não ter interesse em continuar lendo. Como havia uma proporção maior 
de discordantes no grupo experimental, é possível que a distribuição desigual tenha reduzido o valor dos coeficientes, já que a correlação do interesse pela história com o gosto pelo gênero é mais forte que com a qualidade do letreiramento.

Outro fator influente no interesse pela história foi a percepção do personagem principal. No tipo experimental, dos respondentes que concordaram com a afirmação "O personagem principal é interessante", apenas 1,2\% disseram não ter vontade de prosseguir na leitura. O número sobe para $24 \%$ entre os que discordaram com a assertiva, ou seja, vinte vezes maior. No tipo controle, $5 \%$ dos que acharam o protagonista interessante em algum grau não gostariam de ler a continuação. A porcentagem é quase quinze vezes maior para os não cativados, que alcança a proporção de 73\% desinteressados na história.

Desconsiderando as dúvidas de respostas e a indiferença, reduzindo as informações para os extremos "Concordo" e "Discordo", o coeficiente de contingência obtido é de 0,77 , o que, por ser acima de 0,7 , indica forte associação entre interesse pelo personagem principal e interesse em continuar lendo. Um ponto de destaque é que os participantes que leram as páginas com bom letreiramento e não consideraram o personagem como sendo de seu agrado tiveram, proporcionalmente, três vezes mais interessados na leitura do que aqueles que leram as páginas com erros amadores e também não gostaram do protagonista.

Fazendo a mesma análise com outras variáveis, os resultados mostraram associação moderada do interesse na história em relação à leiturabilidade, à clareza da história e ao profissionalismo da equipe, com coeficientes de 0,51, 0,55, e 0,5, respectivamente. Em outras palavras, a vontade de continuar a leitura foi diretamente proporcional às qualidades mencionadas, com intensidade mediana. A variável que apresentou forte correlação, como o interesse pelo protagonista, foi a agradabilidade da leitura, pontuando 0,76.

\subsubsection{Interesse pelo protagonista}

Para saber o grau de associação entre a qualidade do letreiramento e o interesse pelo personagem principal, os dados das duas variáveis foram isolados para serem analisados em conjunto:

Tabela 3. Distribuição conjunta das proporções de participantes segundo o grupo e o grau de concordância para a afirmação "O personagem principal é interessante"

\begin{tabular}{l|c|c|c|c|c|c}
\hline Item & $\begin{array}{c}\text { Concordo } \\
\text { totalmente }\end{array}$ & $\begin{array}{c}\text { concordo em } \\
\text { partes }\end{array}$ & Indiferente & $\begin{array}{c}\text { Discordo em } \\
\text { partes }\end{array}$ & $\begin{array}{c}\text { Discordo } \\
\text { totalmente }\end{array}$ & $\begin{array}{c}\text { Não sei res- } \\
\text { ponder }\end{array}$ \\
\hline Experimental & $32,64 \%$ & $25,69 \%$ & $25,69 \%$ & $9,72 \%$ & $4,86 \%$ & $1,39 \%$ \\
Controle & $15,75 \%$ & $31,50 \%$ & $29,92 \%$ & $11,81 \%$ & $8,66 \%$ & $2,36 \%$ \\
\hline Total & $24,72 \%$ & $28,41 \%$ & $27,68 \%$ & $10,70 \%$ & $6,64 \%$ & $1,85 \%$ \\
\hline
\end{tabular}


Gráfico 2. Gráfico comparativo para o grau de concordância referente à afirmação "O personagem principal é interessante" segundo o tipo do questionário

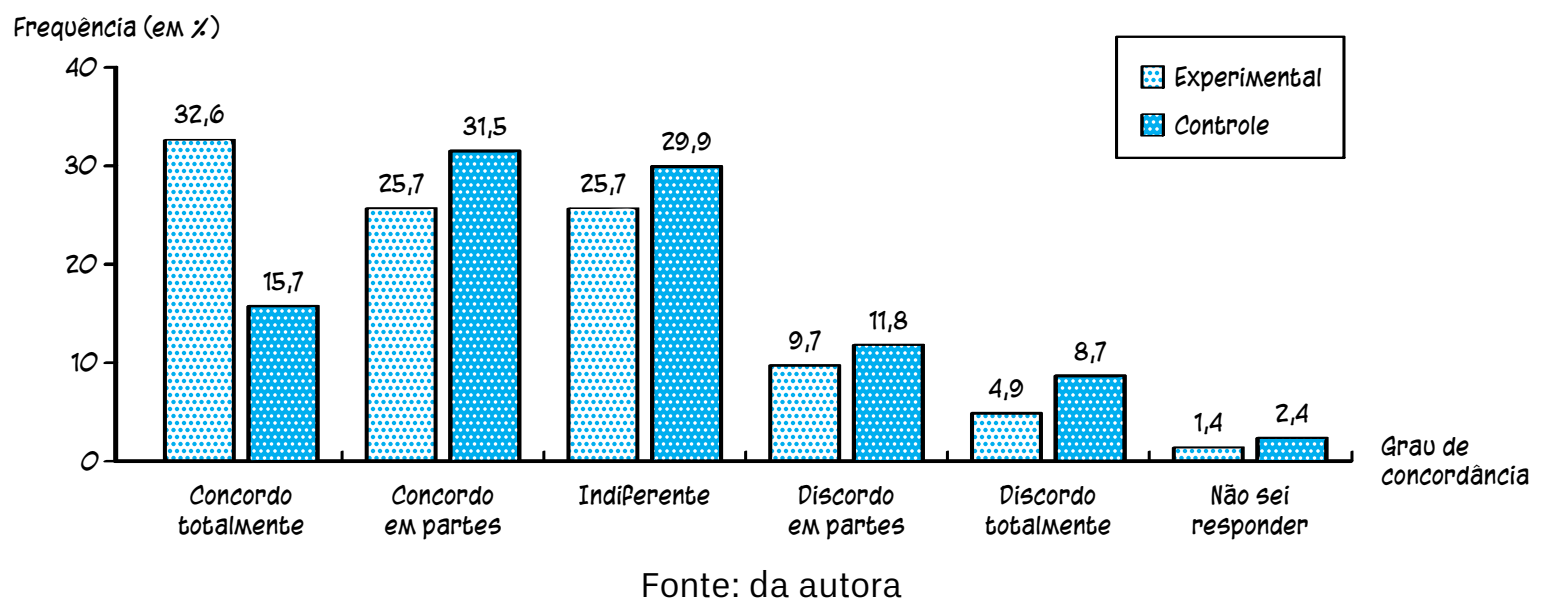

Independente do tipo do grupo, os participantes concordaram mais do que discordaram da afirmação apresentada. Houve uma porcentagem significativa que manteve uma posição neutra em relação à percepção do personagem, possivelmente porque não conseguiram formar uma opinião com base em apenas duas páginas, assim como foi informado por um participante após finalizar o questionário.

Comparando as respostas entre os dois grupos, temos que o tipo controle manteve porcentagens maiores para os dois níveis de discordância. No entanto, a maior diferença está na proporção de respondentes que concordaram totalmente com a afirmativa: no tipo experimental foi mais que o dobro do que no tipo controle, que apresentou maior concordância com ressalvas. Embora a maioria das pessoas tenha se interessado pelo protagonista em ambos os tipos, infere-se que os que leram as páginas com bom letreiramento tiveram um grau maior de afeição e/ou curiosidade pelo personagem.

A tabela de distribuição simplificada para realização dos testes de correlação ficou da seguinte forma:

Tabela 4. Distribuição simplificada das proporções de participantes segundo o grupo e a concordância para a afirmação "O personagem principal é interessante"

\begin{tabular}{l|rr|c}
\hline \multirow{2}{*}{ Tipo de grupo } & \multicolumn{2}{|c|}{ Concordância } & \multirow{2}{*}{ Total } \\
\cline { 2 - 3 } & \multicolumn{1}{|c|}{ concorda } & $\begin{array}{c}\text { Discorda ou } \\
\text { é indiferente }\end{array}$ & \\
\hline Experimental & $84(59,2 \%)$ & $58(40,8 \%)$ & $142(100,0 \%)$ \\
Controle & $60(48,4 \%)$ & $64(51,6 \%)$ & $124(100,0 \%)$ \\
\hline Total & $144(54,1 \%)$ & $122(45,9 \%)$ & $266(100,0 \%)$ \\
\hline
\end{tabular}

Fonte: da autora 
Em geral, o interesse pelo personagem ficou balanceado, com pouco mais da metade dos participantes (que não assinalaram "Não sei responder") em concordância com a afirmação. O grupo experimental apresentou maior porcentagem para os interessados, enquanto o grupo controle teve uma maioria de desinteressados.

O coeficiente de contingência ( $c^{\star}$ ) encontrado foi de 0,15 e os coeficientes Phi $(\phi)$, T de Tschupov e $V$ de Crámer foram calculados em 0,11 . Os dois valores ficaram entre 0 e 0,3, indicando fraca associação entre as variáveis.

Foi recebido contato de dois participantes a respeito da percepção do personagem, com sugestões caso houvesse intenção de publicar a história. Após o fechamento do questionário, soube-se que ambos realizaram o tipo experimental. $O$ primeiro fez referência direta à fonte escolhida para a narração, alegando que a letra dava a impressão de que o protagonista tivesse entre 30 e 40 anos, e, portanto, o público mais jovem poderia não se identificar com ele. O segundo propôs mais leveza à história, pois considerou que o personagem era demasiadamente sério. Como a fonte foi selecionada buscando refletir a ideia de maturidade e sobriedade, a escolha parece ter sido eficiente. No entanto, a maior contribuição levantada por essas mensagens foi a revelação de uma variável que foi ignorada durante a elaboração da pesquisa: o gosto pessoal por determinados traços de personalidade e atributos físicos. A situação ideal envolveria os participantes igualmente distribuídos entre os grupos segundo essa preferência, mas não foram tomadas medidas para certificar que isso tenha ocorrido no questionário aplicado.

Ao cruzar os dados com as demais variáveis e fazer o teste de contingência, observou-se que a opinião sobre o protagonista teve dependência moderada sobre a percepção da leiturabilidade, da clareza da história, do profissionalismo da equipe e do gosto pelo gênero, com coeficientes $0,42,0,43,0,6$ e 0,5, respectivamente.

Assim como ocorreu com o interesse pela história, a agradabilidade da leitura teve forte influência sobre a percepção do personagem, com um coeficiente de 0,8 indicando forte associação.

\subsubsection{Agradabilidade da leitura}

A percepção da leitura como algo agradável não resultou de nenhuma forte associação com outra variável, além do interesse pelo protagonista e do interesse pela leitura, segundo os cálculos do coeficiente $c^{\star}$. No entanto, houve correlação moderada com a facilidade de ler, a clareza da história, o gosto pelo gênero e a percepção do profissionalismo da equipe, com os valores respectivos em 0,57, 0,5, 0,5 e 0,57.

Diferente da leiturabilidade, a agradabilidade da leitura é um conceito mais subjetivo. O primeiro conceito está relacionado com a inteligibilidade, com a facilidade de interpretar os sinais recebidos visualmente, com o processo de compreensão do que foi lido. Já a agradabilidade está mais ligada ao estado afetivo, de forma que, pelo senso comum, a expressão "leitura agradável" se torna sinônimo de "leitura prazerosa". 
Isolando os dados das respostas para "A leitura é agradável" e realizando a análise de acordo com o tipo do questionário, as distribuições resultantes estão representadas a seguir:

Tabela 5. Distribuição conjunta das proporções de participantes segundo o grupo e o grau de concordância para a afirmação "A leitura é agradável"

\begin{tabular}{l|c|c|c|c|c|c}
\hline Item & $\begin{array}{c}\text { Concordo } \\
\text { totalmente }\end{array}$ & $\begin{array}{c}\text { Concordo em } \\
\text { partes }\end{array}$ & Indiferente & $\begin{array}{c}\text { Discordo em } \\
\text { partes }\end{array}$ & $\begin{array}{c}\text { Discordo } \\
\text { totalmente }\end{array}$ & $\begin{array}{c}\text { Não sei res- } \\
\text { ponder }\end{array}$ \\
\hline $\begin{array}{l}\text { Experimental } \\
\text { Controle }\end{array}$ & $39,58 \%$ & $38,89 \%$ & $11,11 \%$ & $7,64 \%$ & $2,08 \%$ & $0,69 \%$ \\
\hline Total & $29,92 \%$ & $38,58 \%$ & $11,81 \%$ & $13,39 \%$ & $5,51 \%$ & $0,79 \%$ \\
\hline
\end{tabular}

Fonte: da autora

Gráfico 3. Gráfico comparativo para o grau de concordância referente à afirmação "A leitura é agradável" segundo o tipo do questionário

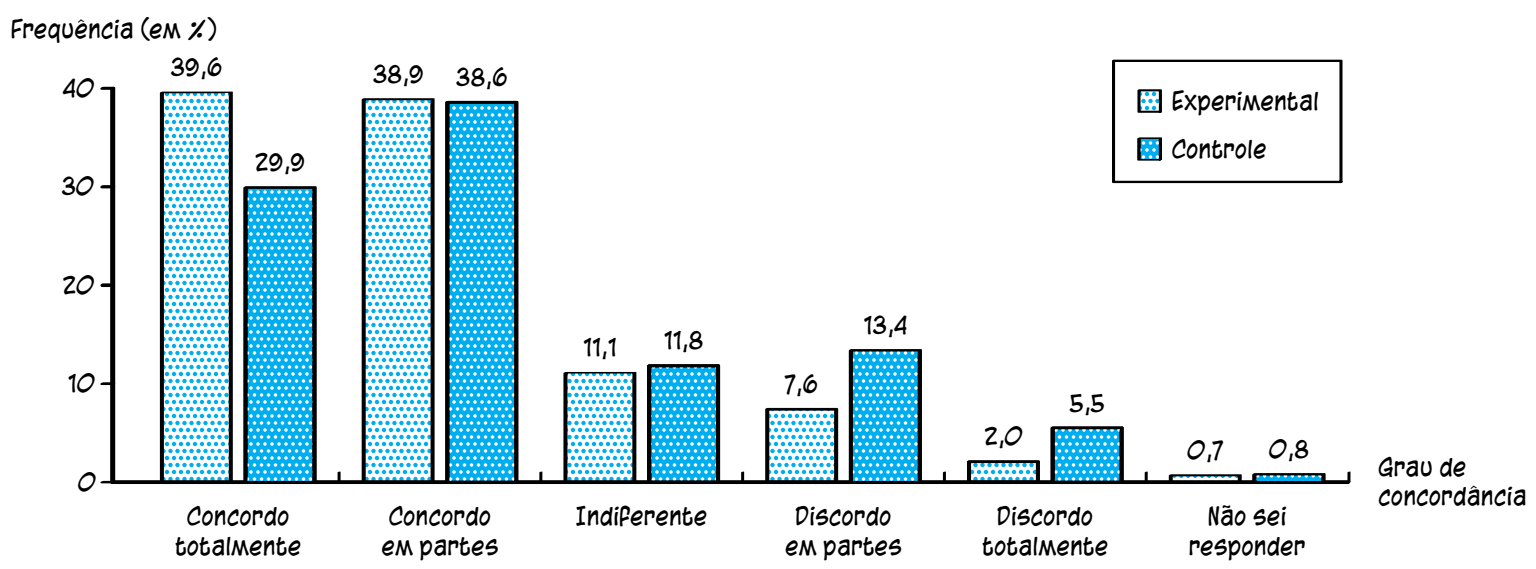

Fonte: da autora

Independentemente do tipo, os participantes concordaram com a afirmação mais do que discordaram. As diferenças mais significativas se encontram nas opções "Concordo totalmente", "Discordo em partes" e "Discordo totalmente", em que o grupo controle apresentou mais discordâncias que o grupo experimental.

Tabela 6. Distribuição simplificada das proporções de participantes segundo o grupo e a concordância para a afirmação "A leitura é agradável"

\begin{tabular}{l|rr|c}
\hline \multirow{2}{*}{ Tipo de grupo } & \multicolumn{2}{|c|}{ Concordância } & \multirow{2}{*}{ Total } \\
\cline { 2 - 3 } & Concorda & $\begin{array}{c}\text { Discorda ou } \\
\text { é indiferente }\end{array}$ & \\
\hline Experimental & $113(79,0 \%)$ & $30(21,0 \%)$ & $143(100,0 \%)$ \\
Controle & $87(69,0 \%)$ & $39(31,0 \%)$ & $126(100,0 \%)$ \\
\hline Total & $200(74,3 \%)$ & $69(25,7 \%)$ & $269(100,0 \%)$ \\
\hline
\end{tabular}

Fonte: da autora 
Os testes de associação aplicados à tabela de contingência simplificada revelaram que existe fraca dependência entre as variáveis, com c* igual a 0,16 e os coeficientes $\phi$, T e V iguais a 0,11. Isso significa que a qualidade da diagramação textual tem pouca influência sobre a percepção da agradabilidade da leitura.

\subsubsection{Leiturabilidade}

Como dito anteriormente, a leiturabilidade está relacionada ao esforço realizado para ler, no sentido de que, quanto maior o esforço necessário, pior é a leiturabilidade. Os testes de correlação revelaram dependência moderada direta do gosto pelo gênero, e influência moderada sobre a clareza da história, a vontade de prosseguir com a leitura, o interesse pelo protagonista, a percepção do profissionalismo da equipe e a agradabilidade da leitura.

A distribuição conjunta dos participantes de acordo com o tipo do questionário e a percepção da leiturabilidade é apresentada a seguir:

Tabela 7. Distribuição conjunta das proporções de participantes segundo o grupo e o grau de concordância para a afirmação "O texto tem boa leiturabilidade, ou seja, não exige esforço para ler"

\begin{tabular}{l|r|r|r|r|r|c}
\hline Item & $\begin{array}{c}\text { Concordo } \\
\text { totalmente }\end{array}$ & $\begin{array}{c}\text { Concordo em } \\
\text { partes }\end{array}$ & Indiferente & $\begin{array}{c}\text { Discordo em } \\
\text { partes }\end{array}$ & $\begin{array}{c}\text { Discordo } \\
\text { totalmente }\end{array}$ & $\begin{array}{c}\text { Não sei res- } \\
\text { ponder }\end{array}$ \\
\hline Experimental & $52,78 \%$ & $33,33 \%$ & $4,86 \%$ & $7,64 \%$ & $1,39 \%$ & $0,00 \%$ \\
Controle & $39,37 \%$ & $26,77 \%$ & $3,94 \%$ & $20,47 \%$ & $7,09 \%$ & $2,36 \%$ \\
\hline Total & $46,49 \%$ & $30,26 \%$ & $4,43 \%$ & $13,65 \%$ & $4,06 \%$ & $1,10 \%$ \\
\hline
\end{tabular}

Fonte: da autora

Gráfico 4. Gráfico comparativo para o grau de concordância referente à afirmação"O texto tem boa leiturabilidade, ou seja, não exige esforço para ler" segundo o tipo do questionário Frequência (eм \%)

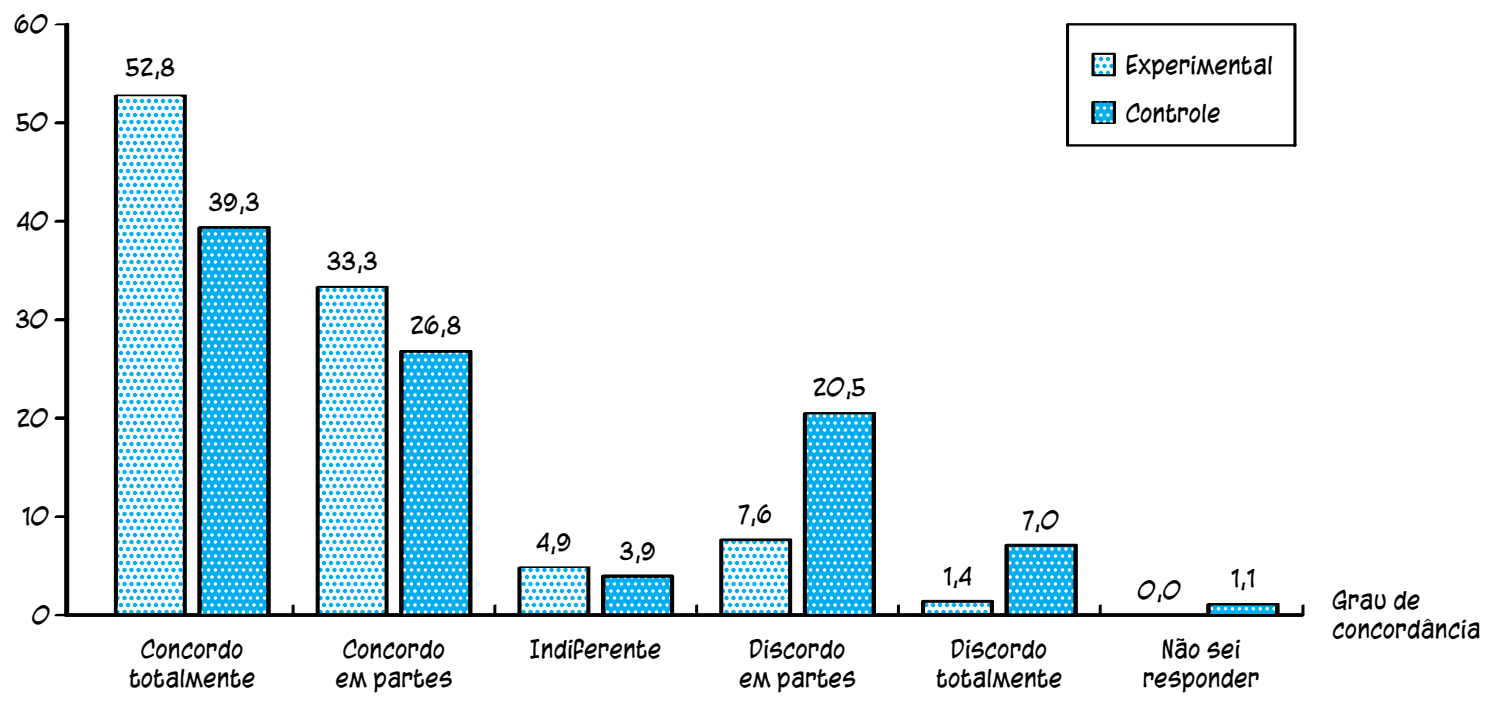

Fonte: da autora 
Analisando os dados, temos que, independentemente do tipo do questionário, mais de $75 \%$ dos participantes concordaram com a assertiva. Vale lembrar que a intenção era de que os erros propositalmente cometidos no tipo controle não comprometessem a legibilidade dos caracteres nem tornassem o texto ininteligível, portanto, já se esperava que a maioria dos respondentes, em ambos os tipos, tivessem uma opinião positiva sobre a leiturabilidade.

Ao observar o gráfico de barras, é possível perceber semelhanças nos graus "Indiferente" e "Não sei responder". No entanto, as outras colunas apresentam diferenças significativas entre os dois tipos, sendo que as colunas foram maiores para o tipo experimental para as concordâncias e maiores para o tipo controle para as discordâncias. Proporcionalmente, os respondentes expostos aos erros propositais tiveram mais marcações negativas sobre a leiturabilidade. Supõe-se que isso seja decorrente da placa "Beco do Príncipe" na segunda página, a qual é menos distinguível no tipo controle.

A versão simplificada da tabela pode ser verificada na Tabela 8.

Tabela 8. Distribuição simplificada das proporções de participantes segundo o grupo e a concordância para a afirmação "O texto tem boa leiturabilidade, ou seja, não exige esforço para ler"

\begin{tabular}{l|rr|c}
\hline \multirow{2}{*}{ Tipo de grupo } & \multicolumn{2}{|c|}{ Concordância } & \multirow{2}{*}{ Total } \\
\cline { 2 - 3 } & Concorda & $\begin{array}{c}\text { Discorda ou } \\
\text { é indiferente }\end{array}$ & \\
\hline Experimental & $124(86,1 \%)$ & $20(13,9 \%)$ & $144(100,0 \%)$ \\
Controle & $84(67,7 \%)$ & $40(32,3 \%)$ & $124(100,0 \%)$ \\
\hline Total & $208(77,6 \%)$ & $60(22,4 \%)$ & $268(100,0 \%)$ \\
\hline
\end{tabular}

Fonte: da autora

Os coeficientes obtidos foram $\phi, T$ e $\vee$ iguais a 0,22 , indicando fraca associação, e c* igual a 0,3, indicando associação moderada. Em outras palavras, a leiturabilidade do texto depende fraca a moderadamente do letreiramento.

\subsubsection{Clareza da história}

Enquanto a leiturabilidade se refere à facilidade de leitura, a clareza tem relação com a transmissão eficaz do conteúdo. Um texto é claro quando sua ideia é facilmente compreendida pelo leitor. Para evitar a ambiguidade com o significado oposto de "escuro", utilizou-se o antônimo "confuso" na afirmação do questionário.

Realizados os testes de correlação, evidenciou-se dependência moderada no sentido direto em relação à leiturabilidade e ao gosto pelo gênero, e influência moderada diretamente proporcional sobre o interesse pela história, o interesse pelo protagonista e a agradabilidade da leitura. Não foram constatadas associações de forte intensidade. 
Analisando conjuntamente os dados do tipo do questionário e do grau de concordância com a falta de clareza da história (Tabela 9), pode-se verificar que, embora mais da metade dos participantes em geral tenham discordado com a a afirmação em algum grau, os discordantes não chegam a 50\% no tipo controle. Enquanto a opção mais votada no tipo controle foi "Discordo totalmente", os respondentes do tipo controle elegeram mais "Concordo em partes".

Tabela 9. Distribuição conjunta das proporções de participantes segundo o grupo e o grau de concordância para a afirmação "A história é confusa"

\begin{tabular}{l|r|c|c|c|c|c}
\hline Grupo & $\begin{array}{c}\text { Concordo } \\
\text { totalmente }\end{array}$ & $\begin{array}{c}\text { Concordo em } \\
\text { partes }\end{array}$ & Indiferente & $\begin{array}{c}\text { Discordo em } \\
\text { partes }\end{array}$ & $\begin{array}{c}\text { Discordo } \\
\text { totalmente }\end{array}$ & $\begin{array}{c}\text { Não sei res- } \\
\text { ponder }\end{array}$ \\
\hline Experimental & $4,17 \%$ & $21,53 \%$ & $15,97 \%$ & $25,69 \%$ & $28,47 \%$ & $4,17 \%$ \\
Controle & $8,66 \%$ & $30,71 \%$ & $14,17 \%$ & $20,47 \%$ & $25,2 \%$ & $0,79 \%$ \\
\hline Total & $6,27 \%$ & $25,83 \%$ & $15,13 \%$ & $23,25 \%$ & $26,94 \%$ & $2,58 \%$ \\
\hline
\end{tabular}

Fonte: da autora

Gráfico 5. Gráfico comparativo para o grau de concordância referente à afirmação "A história é confusa" segundo o tipo do questionário

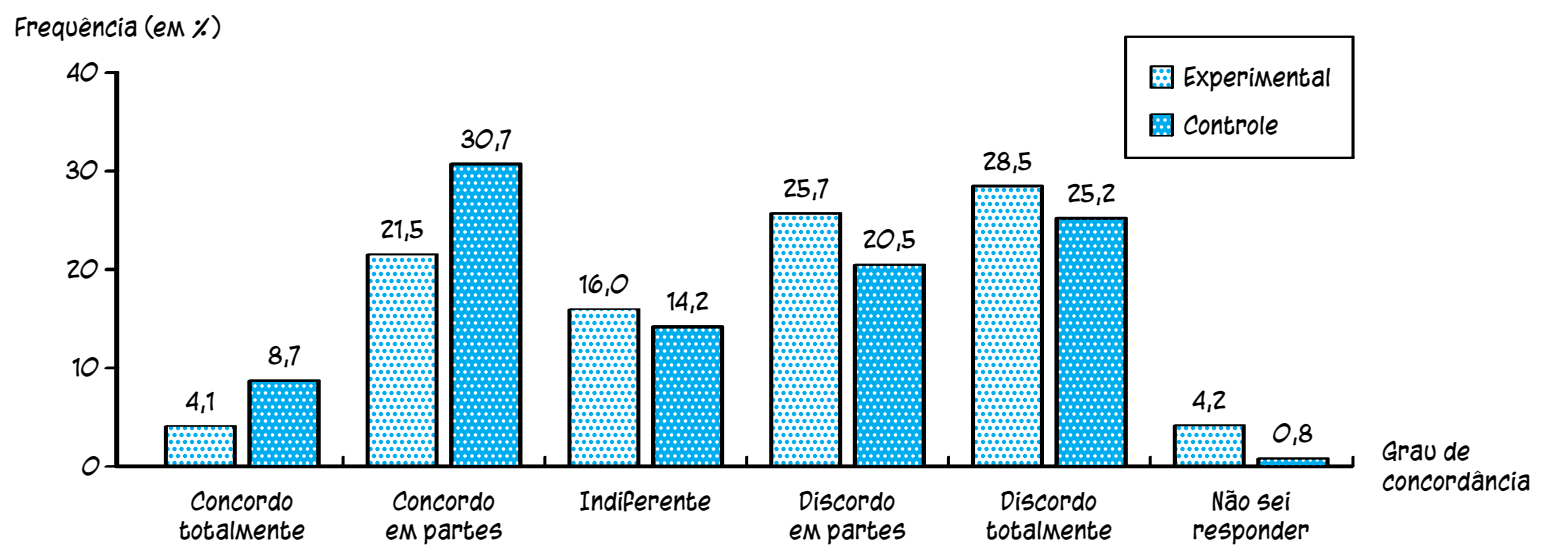

Fonte: da autora

O gráfico correspondente mostra divergências entre as alturas de todas as possíveis respostas. Para determinar a intensidade da associação entre as duas variáveis, foi feita a distribuição simplicada (Tabela 10) e calculados os coeficientes de correlação. O resultado foi que $c^{*}$ é igual a 0,19 e os demais coeficientes citados ficaram iguais a 0,14 . Como os dois valores estão entre 0 e 0,3, infere-se que há associação fraca, no sentido de que a história se torna mais confusa conforme são cometidos mais gafes no letreiramento. 
Tabela 10. Distribuição simplificada das proporções de participantes segundo o grupo e a concordância para a afirmação "A história é confusa"

\begin{tabular}{l|cr|c}
\hline \multirow{2}{*}{ Tipo de grupo } & \multicolumn{2}{|c|}{ Concordância } & \multirow{2}{*}{ Total } \\
\cline { 2 - 3 } & Concorda & $\begin{array}{c}\text { Discorda ou } \\
\text { é indiferente }\end{array}$ & \\
\hline Experimental & $37(26,8 \%)$ & $101(73,2 \%)$ & $138(100,0 \%)$ \\
Controle & $50(39,7 \%)$ & $76(60,3 \%)$ & $126(100,0 \%)$ \\
\hline Total & $87(33,0 \%)$ & $177(67,0 \%)$ & $264(100,0 \%)$ \\
\hline
\end{tabular}

Fonte: da autora

\subsubsection{Ritmo da narrativa}

De maneira oposta às variáveis dos subcapítulos anteriores, o ritmo da narrativa, que pode ser de lento a rápido, não possui um extremo que seja considerado como uma qualidade absolutamente positiva. A demanda pela aceleração ou desaceleração da velocidade como se conduz a história depende de fatores como a tensão que o autor planeja provocar, a relevância do momento para a trama, o estilo da narrativa do escritor, dentre outros.

$\mathrm{Na}$ história criada para o projeto, o ritmo foi predefinido como moderado, em que a narração flui lentamente conforme o feitio sombrio do protagonista, enquanto a transição de eventos à sua volta ocorre de forma mais rápida entre os quadros, a qual foi agilizada em decorrência da restrição do número de páginas. Como a fonte do tipo experimental foi selecionada para ser condizente com a sobriedade e o equilíbrio do personagem, esperava-se que a leitura das páginas experimentais fosse mais devagar devido à entonação proposta.

Entretanto, os dados revelaram um resultado divergente. Como se pode ver na Tabela 11, embora a maioria em geral tenha discordado da assertiva "O ritmo da narrativa é lento" com $41,3 \%$ das marcações, a maioria do grupo controle concordou com a lentidão afirmada, com $49,6 \%$. A maioria do tipo experimental, por outro lado, teve $48,6 \%$ discordando em algum grau.

Tabela 11. Distribuição conjunta das proporções de participantes segundo o grupo e o grau de concordância para a afirmação "O ritmo da narrativa é lento"

\begin{tabular}{l|r|c|c|c|c|c}
\hline Item & $\begin{array}{c}\text { Concordo } \\
\text { totalmente }\end{array}$ & $\begin{array}{c}\text { concordo em } \\
\text { partes }\end{array}$ & Indiferente & $\begin{array}{c}\text { Discordo em } \\
\text { partes }\end{array}$ & $\begin{array}{c}\text { Discordo } \\
\text { totalmente }\end{array}$ & $\begin{array}{c}\text { Não sei res- } \\
\text { ponder }\end{array}$ \\
\hline Experimental & $4,86 \%$ & $25,69 \%$ & $17,36 \%$ & $25,69 \%$ & $22,92 \%$ & $3,47 \%$ \\
Controle & $11,02 \%$ & $38,58 \%$ & $17,32 \%$ & $22,05 \%$ & $11,02 \%$ & $0,00 \%$ \\
\hline Total & $7,75 \%$ & $31,73 \%$ & $17,34 \%$ & $23,99 \%$ & $17,34 \%$ & $1,85 \%$ \\
\hline
\end{tabular}

Fonte: da autora 
Gráfico 6. Gráfico comparativo para o grau de concordância referente à afirmação "O ritmo da narrativa é lento" segundo o tipo do questionário

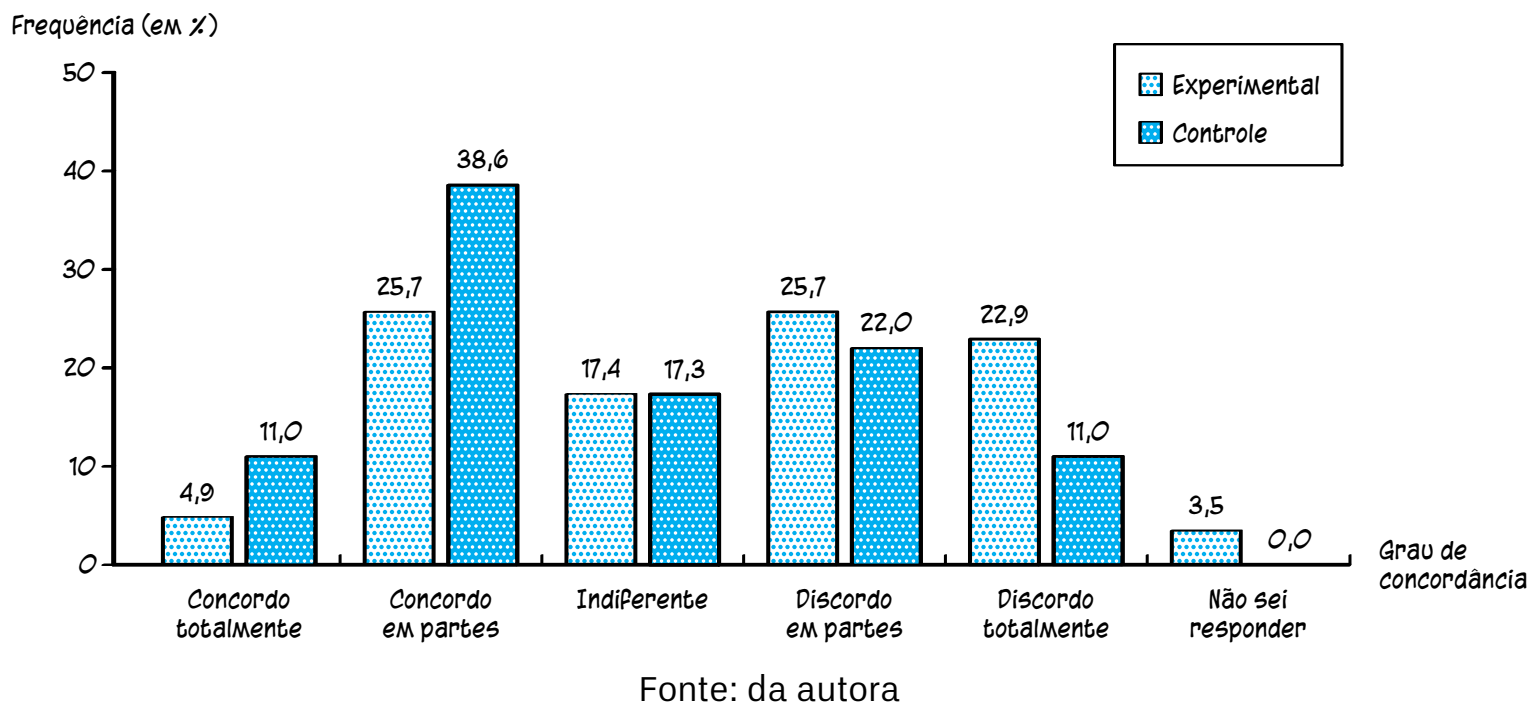

O gráfico representa visualmente a discrepância de marcações em "Concordo em partes" entre os dois grupos. Enquanto as colunas do grupo controle são maiores nas concordâncias, o grupo experimental teve proporções maiores de discordantes, deixando evidente que houve uma porcentagem maior no grupo controle de participantes que acharam a narrativa lenta. Isso pode ser porque, em relação às outras variáveis, o ritmo apresentou associação moderada com a leiturabilidade, no sentido de que, quanto melhor a leiturabilidade, menos os participantes concordaram com a lentidão da narrativa. Como o grupo experimental teve mais concordantes com a leiturabilidade do texto, é provável que tenha havido interferência no resultado obtido.

Desta vez, a distribuição simplificada ignorou também os dados de indiferença, pois não seriam aplicáveis em nenhum dos extremos.

Tabela 12. Distribuição simplificada das proporções de participantes segundo o grupo e a concordância para a afirmação "O ritmo da narrativa é lento"

\begin{tabular}{l|rr|c}
\hline \multirow{2}{*}{ Tipo de grupo } & \multicolumn{2}{|c|}{ Concordância } & \multirow{2}{*}{ Total } \\
\cline { 2 - 3 } & \multicolumn{1}{|c|}{ Concorda } & \multicolumn{1}{c}{ Discorda } & \\
\hline Experimental & $44(41,5 \%)$ & $70(58,5 \%)$ & $114(100,0 \%)$ \\
Controle & $63(55,8 \%)$ & $42(44,2 \%)$ & $105(100,0 \%)$ \\
\hline Total & $107(48,9 \%)$ & $112(51,1 \%)$ & $219(100,0 \%)$ \\
\hline
\end{tabular}

Fonte: da autora

Os coeficientes resultantes foram $\phi, T$ e $\vee$ iguais a 0,21 , indicando fraca associação, e c* igual a 0,3, indicando associação moderada. Em outras palavras, a a percepção ritmo da narrativa tem correlação fraca a moderada com o letreiramento. 


\subsubsection{Profissionalismo da equipe}

Segundo Ron Marz, um dos métodos mais fáceis de fazer uma obra parecer amadora é concebendo um letreiramento amador. Para verificar a validade dessa afirmação, foi acrescentado o item "A equipe que fez essa história parece profissional" no questionário. Em relação às outras variáveis, como foi apresentado nos subcapítulos anteriores, a percepção do profissionalismo apresentou associação moderada diretamente proporcional com a leiturabilidade, com o interesse em prosseguir com a história, com o interesse pelo protagonista e com a agradabilidade da leitura.

Ao isolar os dados segundo o tipo do grupo, obteve-se a seguinte distribuição:

Tabela 13. Distribuição conjunta das proporções de participantes segundo o grupo e o grau de concordância para a afirmação "A equipe que fez essa história parece profissional"

\begin{tabular}{l|r|c|c|c|c|c}
\hline Item & $\begin{array}{c}\text { Concordo } \\
\text { totalmente }\end{array}$ & $\begin{array}{c}\text { concordo em } \\
\text { partes }\end{array}$ & Indiferente & $\begin{array}{c}\text { Discordo em } \\
\text { partes }\end{array}$ & $\begin{array}{c}\text { Discordo } \\
\text { totalmente }\end{array}$ & $\begin{array}{c}\text { Não sei res- } \\
\text { ponder }\end{array}$ \\
\hline Experimental & $40,97 \%$ & $41,67 \%$ & $6,94 \%$ & $7,69 \%$ & $1,39 \%$ & $1,39 \%$ \\
Controle & $32,28 \%$ & $31,50 \%$ & $11,81 \%$ & $19,69 \%$ & $4,72 \%$ & $0,00 \%$ \\
\hline Total & $36,90 \%$ & $36,90 \%$ & $9,23 \%$ & $13,28 \%$ & $\mathbf{2 , 9 5 \%}$ & $0,74 \%$ \\
\hline
\end{tabular}

Fonte: da autora

Gráfico 7. Gráfico comparativo para o grau de concordância referente à afirmação "A equipe que fez essa história parece profissional" segundo o tipo do questionário

Frequência $(e M \%)$

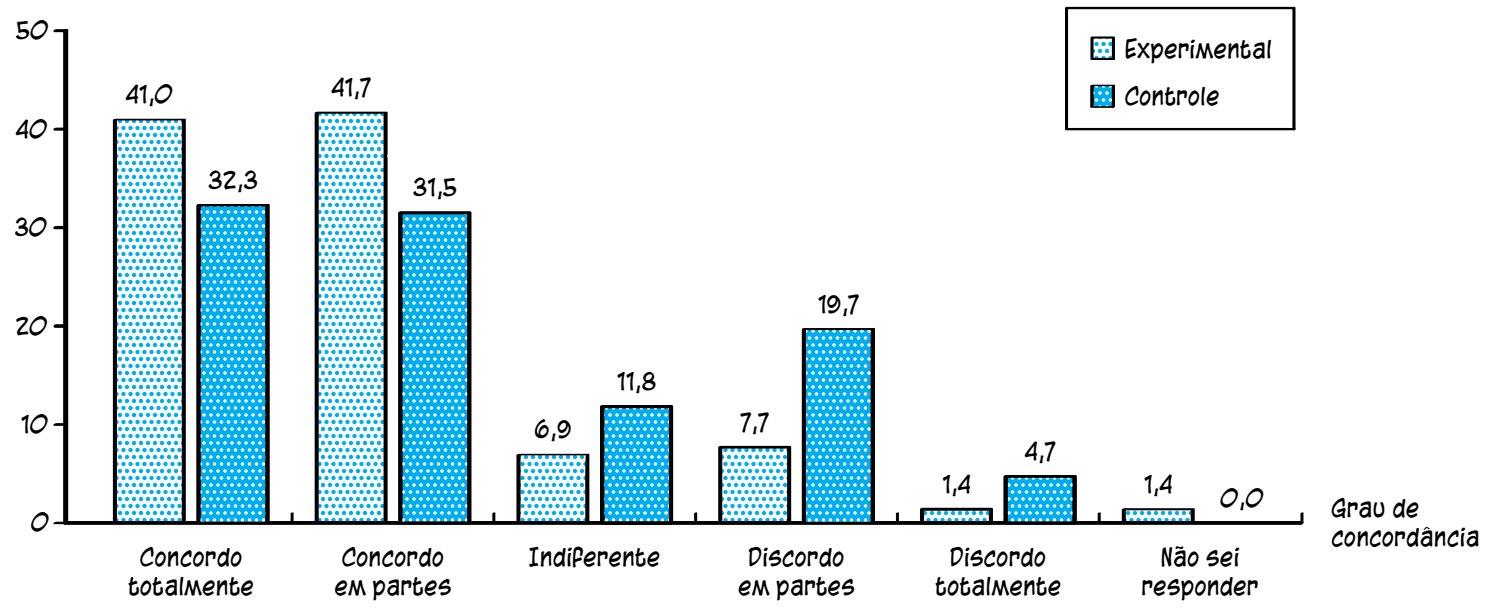

Fonte: da autora

Indepentendente do tipo do grupo, a maioria dos participantes concordou com a afirmação em algum grau, com $73,8 \%$ das marcações. De certa forma, já se esperava uma porcentagem alta maior que $50 \%$, pois a opinião referente ao profissionalismo de uma obra envolve critérios como a arte e o enredo, que foram elaborados por pessoas experientes e não sofreram alterações entre os dois tipos. 
Observando o tamanho das colunas no gráfico, nota-se que o grupo experimental teve maior porcentagem para os dois níveis de concordância, enquanto o grupo controle teve dominância nos de discordância. Com base nas diferenças visíveis das porcentagens para os totais marginais, decidiu-se testar a associação pela distribuição simplificada.

Tabela 14. Distribuição simplificada das proporções de participantes segundo o grupo e a concordância para a afirmação "A equipe que fez essa história parece profissional"

\begin{tabular}{l|r|r|c}
\hline \multirow{2}{*}{ Tipo de grupo } & \multicolumn{2}{|c|}{ Concordancia } & \multirow{2}{*}{ Total } \\
\cline { 2 - 3 } & concorda & $\begin{array}{r}\text { Discorda ou } \\
\text { é indiferente }\end{array}$ & $142(100,0 \%)$ \\
\hline Experimental & $119(83,8 \%)$ & $23(16,2 \%)$ & $127(100,0 \%)$ \\
Controle & $81(63,8 \%)$ & $46(36,2 \%)$ & $269(100,0 \%)$ \\
\hline Total & $200(74,3 \%)$ & $69(25,7 \%)$ & 26 \\
\hline
\end{tabular}

Fonte: da autora

Os coeficientes encontrados $\phi$, T e $\vee$ foram iguais a 0,23 , indicando fraca associação, e o coeficiente $c^{*}$ ficou igual a 0,32, indicando associação moderada. Portanto, foi detectada uma correlação fraca a moderada entre o letreiramento e a percepção do profissionalismo, no sentido de que, quanto melhor o letreiramento, mais o participante é favorável a achar a equipe profissional. 

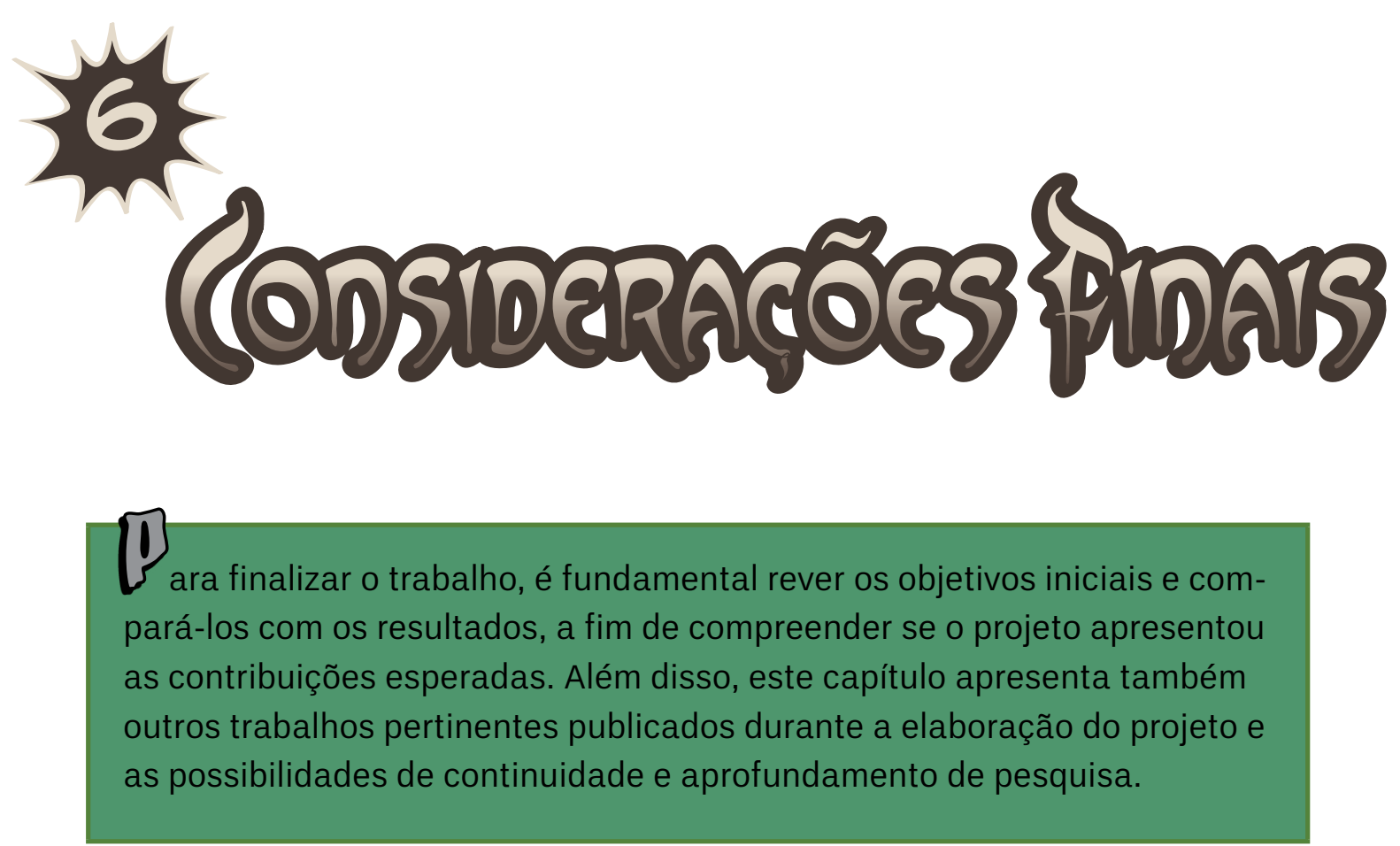

Apesar de existirem obras detalhadas referentes ao letreiramento, como os livros de Roshell e Starkings (2003), Klein (2004), Lainé e Delzant (2010), a quantidade é irrisória se comparada às publicações existentes sobre a arte e o enredo dos quadrinhos. Uma das finalidades deste projeto foi suprir a falta de estudos sobre essa etapa de produção, especialmente no âmbito nacional, onde o letreiramento ainda é pouco conhecido.

Para esclarecer como o letreiramento surgiu, foi realizada uma abordagem inédita da trajetória histórica das HQs, com ênfase em elementos da diagramação textual, incluindo os suportes onde eles são inseridos. Foi visto que a busca por soluções para a representação da comunicação oral em imagens remonta a séculos a.C., e que foi necessário um longo processo de experimentações para chegarmos ao conjunto visual que conhecemos hoje. Mesmo o balão de diálogo, símbolo mundialmente reconhecido atualmente, foi rejeitado inúmeras vezes e alguns países só passaram a adotá-lo na década de 50. Explicou-se também o impacto de eventos históricos, como as proibições fascistas, a influência do estilo hippie nos quadrinhos underground e a influência do estilo dos quadrinhos no movimento Pop Art.

O método adotado foi de apenas mencionar os acontecimentos mais importantes para o letreiramento, mas muitos destes permitem investigações mais detaIhadas, como é o caso dos padrões adotados para as diferentes temáticas predominantes em épocas variadas (ficção científica nos anos 30, crime nos anos 40 e 50, romance no fim dos anos 40 , etc.), a aceitação do balão como indicador de fala ou até mesmo estudos sobre a evolução do letreiramento em locais específicos. Ademais, nomes como Osamu Tezuka e Walt Kelly merecem ter seus trabalhos em letreiramento analisados com mais detalhes, como já foi feito com Rick Griffin (Heller, 
2012). Isso mostra que trata-se de uma área que ainda tem muito a ser explorado e a ampliação do número de pesquisas pode colaborar com a visibilidade do ofício, que poderá ser mais valorizado a partir do estudos feitos.

O letreiramento foi conceituado, principalmente, através do detalhamento de suas incumbências, visto que a definição "etapa responsável pela inserção de todos os tipos de texto nas páginas de quadrinhos" pareceu demasiadamente simplista. A explanação de como é planejado e executado esse procedimento tornou claras as complexidades envolvidas. O esclarecimento de que a tarefa do letreirista abrange escolha cuidadosa de fontes, posicionamento adequado do texto, complementação da arte, orientação do olhar do leitor, representação de voz, entre outros aspectos que enriquecem a narrativa, demonstra a importância de saber realizar o trabalho para o resultado final da obra. Com maior divulgação e entendimento das diretrizes mostradas nesta dissertação, espera-se que haja uma conscientização dos leitores e dos quadrinistas a respeito dos requisitos que tornam o letreiramento benfeito. Por consequência, a expectativa é de que, a longo prazo, haja um aumento na qualidade do letreiramento e que as editoras passem a definir requisitos mais rigorosos e específicos para selecionarem profissionais letreiristas.

Para entender o ponto de vista de quem trabalha na área, os questionários foram aplicados e tiveram respostas satisfatórias. Nate Piekos e Troy Peteri enxergam uma ligação estreita entre o letreiramento e o design gráfico, e, de forma semelhante ao design, constatou-se que não há um passo-a-passo exato de como letreirar e que o resultado depende fundamentalmente das noções de diagramação desenvolvidas pelo profissional. A maioria dos entrevistados afirmou também que o bom senso tem participação significativa para associar as palavras escritas ao som que se deseja transmitir, como, por exemplo, na escolha do visual das onomatopeias. Assim como o ofício do diagramador, a forma de trabalho em relação ao resto da equipe varia conforme a experiência com os demais integrantes, conforme a editora e conforme o projeto.

Como ainda existe a discussão sobre letreiramento à caneta e letreiramento digital, procurou-se saber sobre o posicionamento dos profissionais acerca desse assunto. A preferência unânime é de utilizar o computador, devido às facilidades que este apresenta. No entanto, os letreiristas apontaram várias desvantagens, como o aumento da oferta de serviços baratos e "medíocres", como descrito por Nate, porque agora qualquer um pode comprar uma fonte e letreirar uma HQ, mas nem sempre os iniciantes se preocupam com os aspectos de uma diagramação eficiente. Isso contribui para uma queda da qualidade em prol do baixo custo, causando desvalorização da profissão. Mesmo assim, os benefícios do método digital parecem superar os pontos negativos, visto que o letreiramento eletrônico é a prática predominante no mercado.

Na pesquisa com o público, como era esperado, não houve diferenças drásticas entre os dois grupos trabalhados. Contudo, a própria existência de discrepâncias é significativa, porque ela foi originada por erros sutis de letreiramento. $O$ fato 
de pequenas gafes terem causado pequenas alterações nos dados já indica haver influência da forma como é disposto o texto sobre a percepção dos leitores. E, assim como foi demonstrado pelos testes de correlação, a variável independente mostrou fraca associação proporcionalmente direta com a vontade de continuar a ler, com o interesse pelo protagonista, com a percepção da agradabilidade da leitura e com a clareza da história; e associação moderada com a leiturabilidade, com a percepção do ritmo da narrativa e com a percepção do profissionalismo da equipe. No entanto, como foi observado, outras variáveis afetaram as respostas, como a preferência pelo gênero e o gosto ou desgosto por determinadas características nos personagens, que não tiveram igual distribuição entre os grupos ou que não foram previstas. Embora as interferências não invalidem as análises de dependência, a precisão do resultado é reduzida.

Para que a influência do letreiramento fosse medida com mais exatidão, seriam necessárias mais repetições e variações da pesquisa, neutralizando quaisquer fontes de distorção e testando níveis diferentes de qualidade. Como o objetivo da pesquisa era captar se existe associação ou não, considera-se que o experimento foi satisfatório para obter as respostas desejadas.

\section{Objetivo geral}

Sobre o objetivo geral do trabalho, definido como "apresentar a importância do letreiramento para as histórias em quadrinhos", acredita-se que este tenha sido atingido. Foi apresentada a importância do letreiramento no percurso histórico das histórias em quadrinhos e para a própria consolidação da mídia mundialmente. Mostrou-se também a contribuição dessa etapa para enriquecer a narrativa, com ênfase na orientação do olhar do leitor, na distinção de personagens, na sugestão de ruídos e de entonação de voz. Além disso, foram expostos diferentes pontos de vista sobre a colaboração do letreirista na $\mathrm{HQ}$. Por fim, os resultados da pesquisa revelaram que erros amadores tendem a gerar mais opiniões negativas sobre os aspectos estudados.

\section{Objetivos específicos}

Os objetivos específicos também foram todos cumpridos. Assim como proposto, o processo histórico do letreiramento foi descrito com menções ao surgimento das tradições, como o balão e pontuações específicas, e foram cronologicamente referenciados os acontecimentos históricos que inspiraram os estilos da época ou que interviram na adoção de algum elemento visual.

As atividades intrínsecas do letreiramento (posicionamento do balão, seleção de fonte, desenho de suporte, etc.) foram explicadas com os respectivos efeitos causados sobre a percepção do texto. Junto a isso, já eram detalhadas as boas práticas para cada sub-etapa e os erros a serem evitados. 
Através dos questionários respondidos pelos profissionais, foram obtidas diversas informações para maior entendimento da profissão dos letreiristas, como a comunicação com a equipe e o processo de escolha de um estilo para a obra.

E, com a pesquisa final, o último objetivo específico foi alcançado, que consistia em encontrar elementos afetados nas histórias em quadrinhos pela qualidade do letreiramento.

\section{Contribuição ao design}

Em relação à contribuição ao design, é válido lembrar que alguns dos entrevistados consideram a execução do letreiramento como execução do design gráfico, pois são necessárias noções de diagramação para realizar um bom trabalho. É importante destacar que o mercado brasileiro possui poucos materiais que fazem aprofundamentos no tema tratado, e esta dissertação apresenta uma grande compilação de diversos estudos existentes pelo mundo.

Como dito anteriormente, espera-se que este trabalho abra portas para projetos maiores de estudo do letreiramento e de conscientização dos leitores para detectarem os erros e demandarem maior nível de qualidade das publicações nacionais. Por consequência, isso traria maior valorização ao profissional e indiretamente ao design de informação.

\section{Outros trabalhos realizados}

Para a produção acadêmica na área, foram publicados artigos durante o desenvolvimento desta pesquisa. O primeiro deles foi no VIII World Congress on Communication and Arts, WCCA (2015), com o nome de "Evolução do letreiramento nas histórias em quadrinhos", o qual sumariza os principais acontecimentos da história do letreiramento.

Foi aceito também um artigo para ser apresentado no VII Congresso Internacional de Design da Informação, CIDI (2015), escrito em parceria com o prof. dr. Luiz Fernando Luzzi Las-Casas, com o nome de "A distinção de personagens nas histórias em quadrinhos por meio do letreiramento", com o objetivo de apresentar o potencial gráfico para auferir diferentes vozes aos personagens.

Existem ainda possibilidades de realizar mais publicações explorando outras seções desta pesquisa, principalmente as referentes ao embate dos métodos de execução e ao experimento e seus resultados. 


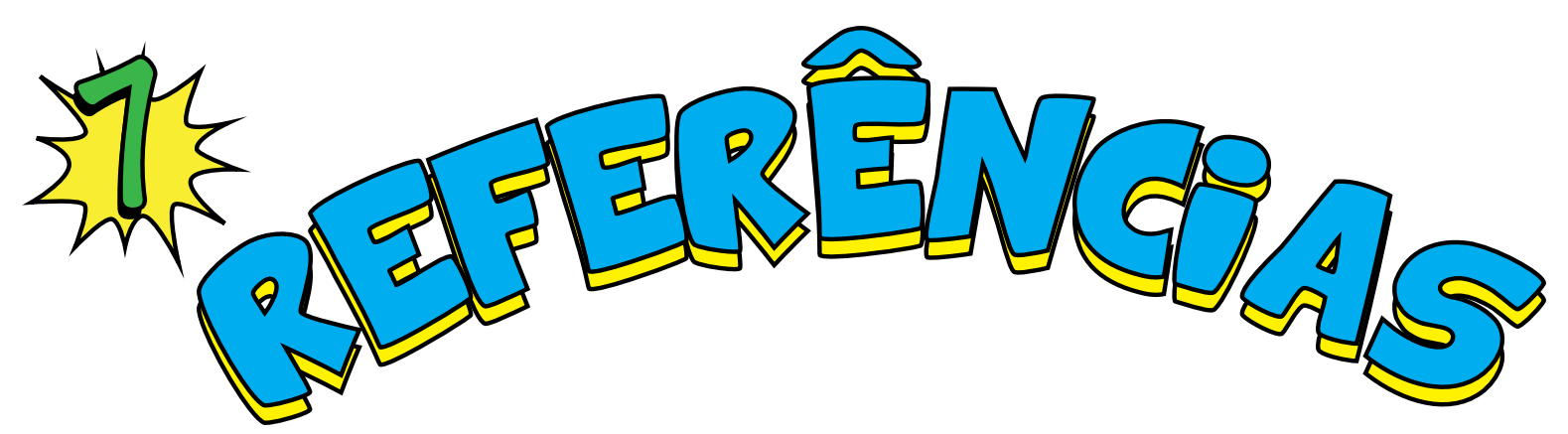

\section{Referências bibliográficas}

AMEND, K. K.; RUIZ, M. S. Hand writing analysis: the complete basic book. Nova Jérsei (EUA): New Page Books, 1980. 196 p.

BAN, T. Osamu Tezuka: uma biografia mangá. São Paulo: Conrad, 2004. 302 p.

BENAYOUN, R. Le ballon dans la bande dessinée: vroom, tchac, zowie. Paris (FR): André Balland, 1968. $111 \mathrm{p}$.

BRINGHURST, R. Elementos do estilo tipográfico. $3^{a}$ ed. São Paulo: Cosac Naify, 2005. $432 \mathrm{p}$.

BROOKE, W. Batman unmasked: analyzing a cultural icon. Nova lorque (EUA): Continuum International Publishing Group, 2005. 361 p.

CARLSON, G. L. Learn to draw comics. Nova Iorque (EUA): Dover, 2002. 64 p.

CIRNE, M. BUM! A explosão criativa dos quadrinhos. 5ª edição. Petrópolis: Vozes, 1977. $70 \mathrm{p}$.

COMPARATO, Doc. Da criação ao roteiro: teoria e prática. $2^{a}$ edição. São Paulo: Summus, 2009. 496 p.

DANZIGER-RUSSELL, J. Girls and their comics: finding a female voice in comic book narrative. Maryland (EUA): Scarecrow Press, 2013. 247 p.

DEFOREST, T. Wash Tubbs: an unlikely adventurer. In: (Org.). Storytelling in the pulps, comics, and radio: how technology changed popular fiction in America. Carolina do Norte (EUA): McFarland, 2004. P. 115-121. 
York (EUA): Continuum International Publishing Group, 2009. 360 p.

EISNER, W. Narrativas gráficas. 1a ed. São Paulo: Devir, 2005. 168 p.

—. Quadrinhos e arte sequencial. 3ª ed. São Paulo: Martins Fontes, 2010. 154 pp.

FERNANDES, C. A. Conhecendo os componentes da construção da obra. In: O mito em Chico Bento e Papa-Capim. Pontífica Univerdade Católica do Rio de Janeiro, 2006. P. 39-93.

GIROMINI, F.; MARTELLI, M. GULP! 100 anni a fumetti: un secolo di disegni, avventure, fantasia. Milano (IT): Electa, 1996. 311 p.

HELLER, S. The graphic design reader. Nova Iorque (EUA): Allworth Press, 2002. 279 p.

HULL, K. M. Verbal art and performance in Ch'orti' and Maya hieroglyphic writing. 2003. 696 f. Tese (Doutorado em Filosofia) - Universidade de Texas, Austin. 2003.

HUMEZ, A.; HUMEZ, N. On the dot: the speck that changed the world. Nova lorque (EUA): Oxford University Press, 2008. 272 p.

INGE, M. T. Will Eisner: Conversations. Mississipi (EUA): University Press of Mississippi, 2011. $224 \mathrm{p}$.

IRVING, C. A Piece of the Action: Charlton's Action Hero Line and the Folks Responsible. Comic Book Artist: the Charlton Comics Story, TwoMorrows Publishing, Carolina do Norte (EUA), n. 9, p. 25-29, ago. 2000.

JEAN, G. A escrita: memória dos homens. Rio de Janeiro: Objetiva, 2002. 224 p.

KERLINGER, Thomas C.; TAYLOR, James R. Marketing research: an applied approach. Tóquio: McGraw-Hill Kogakusha, 1979.

KINSELLA, S. Cuties in Japan. In: MOERAN, B.; SKOV, L. Women, media and consumption in Japan. Richmond (UK): Curzon Press, 1995. P. 220-254.

KLEIN, T. Lettering. In: _-; CHIARELLO, M. The DC Comics Guide to Coloring and Lettering Comics. Nova Iorque: Watson-Guptill Publications, 2004. P. 82-141.

- The ABCs of Design: beyond the letters and logos of Moore's comics with 
Todd Klein. Comic Book Artist: the ABC Comics of Alan Moore \& Friends, TwoMorrows Publishing, Carolina do Norte (EUA), n. 25, p. 56-57, jun. 2003.

KOKKO, V. Kpow, Chink, Splat: translations of sound effects in seven comics. 2013. 106 f. Dissertação (Mestrado em Tradução e Interpretação de Inglês) - Universidade de Turku, Finlândia. 2013.

LAINÉ, J. M.; DELZANT, S. Le lettrage des bulles. Paris (FR): Groupe Eyrolles, 2010. $96 \mathrm{p}$.

LEE, S. How do draw comics: from the legendary co-creator of Spider-Man, The Incredible Hulk, Fantastic Four, X-Men, and Iron-Man. Nova Iorque: Watson-Guptill, 2010. 224 p.

LIMA, F. F. Onomatopéia: som para ver. In: Viñetas Serias, 1, 2010. Buenos Aires (AR). Atas digitais. $5 \mathrm{p}$.

LUYTEN, S. M. B. Mangá: o poder dos quadrinhos japoneses. São Paulo: Hedra, 2012. $3^{a}$ ed. 220 p.

- Onomatopeias e mímesis no mangá. Revista USP, São Paulo, n.52, p. 176-188, dez/fev. 2001-2002.

MAZUR, D.; DANNER, A. Quadrinhos: história moderna de uma arte global. São Paulo: WMF Martins Fontes, 2014. 320 p.

MCCLOUD, S. Desvendado os quadrinhos. São Paulo: M. Books, 2005. 218 p.

MOYA, A. O mundo de Disney. São Paulo: Geração Editorial, 1996. 139 p.

NYBERG, A. K. Seal of approval: the history of the comics code. EUA: University Press of Mississipi, 1998. 211 p.

PATATI, C.; BRAGA, F. Almanaque dos quadrinhos: 100 anos de uma mídia popular. Rio de Janeiro: Ediouro, 2006. 224 p.

PETERSEN, R. Comics, manga and novels: a history of graphic narratives. California (EUA): Praeger, 2010. 274 p.

ROSHELL, J.; STARKINGS, R. Comic book lettering: the Comicraft way. Edição única. Los Angeles: Active Images, 2003. 64 p. 
SHROCK, J. The Gilded Age. Estados Unidos: Greenwood, 2004. 1a ed. 344 p.

SOUSA, G. K. K. Novas possibilidades em metalinguagem. Monografia - UniCeub, Brasília, 2006. 69 p.

SZYMANCZYK, I. O. Historia de las historietas en Argentina. Buenos Aires (AR): Duncan, 2014. $1^{\text {a }}$ ed. $168 \mathrm{p}$.

TORIYAMA, A.; SAKURA, A. Mangaka: lições de Akira Toriyama. Edição única. São Paulo: Conrad, 2002. 190 p.

TSCHICHOLD, J. A forma do livro: ensaios sobre tipografia e estética do livro. Cotia, SP: Ateliê Editorial, 2007. 224 p.

VAN LENTE, F.; DUNLAVEY,. R. The comic book history of comics. San Diego (EUA): IDW Publishing, 2012. 224 p.

VILLAS-BOAS, A. O que é [e o que nunca foi] design gráfico. $5^{\mathrm{a}}$ ed. Rio de Janeiro: 2AB Editora, 2003. 74 p.

WALKER, B. The comics: before 1945. Nova lorque (EUA): Harry N. Abrams, Inc., 2004. 336 p.

WALKER, M. The lexicon of comicana. Indiana (EUA): iUniverse, 2000. 108 p.

WORCESTER, K.; HEER, J. A comics studies reader. Mississipi (EUA): University Press of Mississipi, 2004. 385 p.

ZANETTIN, F. Comics in translation. Manchester (UK): St. Jerome Publishing, 2008. $322 \mathrm{p}$. 


\section{Referências eletrônicas}

BELL, J. L. Superman battles the challenge of thought!. Oz and Ends, Massachussets (EUA), abr. 2010. Disponível em: <http://ozandends.blogspot.com.br/2010/04/ superman-battles-challenge-of-thought.html>. Acesso em: 30 nov. 2014.

BRADLEY, D. The history of comics lettering. Multiversity Comics, abr. 2014. Disponível em: <http://multiversitycomics.com/columns/history-of-comic-lettering-early-years-to-1940/>. Acesso em: 29 jul. 2014.

CAMPBELL, J. Lettering in Illustrator: Three. Man of letters, out. 2010. Disponível em: $<$ http://clintflickerlettering.blogspot.com.br/2010/10/lettering-in-adobe-illustrator-three.html>. Acesso em: 30 jul. 2014.

EVANIER, M. Point of view: computer lettering. News from me, 17 jan. 1997. Disponível em: <http://www.newsfromme.com/pov/col117/>. Acesso em: abr. 2015.

GRAVETT, P. D. Comics: a brief history. The cartoonists club of Great Britain, São Paulo, set. 2005. Disponível em: <http://www.ccgb.org.uk/lobby/index.php?/archives/11-Comics-A-Brief-History-by-Paul-Gravett.html />. Acesso em: 29 jul. 2014.

KLEIN, T. The rise of digital lettering. Todd's blog, nov. 2014. Disponível em: <http:// kleinletters.com/Blog/the-rise-of-digital-lettering-part-1/>. Acesso em: abr. 2015.

KONKYCRU, A. Evolution of speechballoons. Londres, 2003. Disponível em: <http:// bugpowder.com/andy/e.speechballoons.evolution.html>. Acesso em: 31 jul. 2014.

Andy's early comics archive. Londres, 2011. Disponível em: <http://konkycru.com>. Acesso em: 31 jul. 2014.

LEFÈVRE, P. The battle over the balloon: the conflictual institutionalization of the speech balloon in various European cultures. Image [\&] Narrative, Lovaina, v. 7, n. 1, jul. 2006. Disponível em: <http://www.imageandnarrative.be/inarchive/painting/ pascal_levevre.htm>. Acesso em: 31 jul. 2014.

MARSDEN, R. Interesting object: the speech balloon. The Independent, Londres, 30 nov. 2013. Disponível em: <http://www.independent.co.uk/arts-entertainment/ books/features/interesting-object-the-speech-balloon-8967847.html>. Acesso em: 29 jul. 2014.

MARZ, R. Shelf Life: The Art of Lettering. Comic Book Resources, 26 jan. 2012. Dispo- 
nível em: <http://www.comicbookresources.com/?page=article\&id=36639>. Acesso em: abr. 2015.

MITSUNAGA, L. Entrevista: Lilian Mitsunaga - A melhor letrista do Brasil: depoimento. [9 abr. 2015]. Colecionadores de HQs. Disponível em: <http://colecionadoresdehqs.com.br/entrevista-lilian-mitsunaga-a-melhor-letrista-do-brasil/>. Acesso em: abr. 2015.

MORRIS, J. My plea for hand lettering. Against His Immense and Terrible Flesh, 13 abr. 2012. Disponível em: <http://calamityjon.tumblr.com/post/21029710863/ive-been-considering-revisiting-my-plea-for>. Acesso em: mai. 2015.

OATLEY, C. Comic layout tutorial: the comic lettering spell. ChrisOatley.com, jul. 2012. Disponível em: <http://chrisoatley.com/comic-lettering-comic-layout/>. Acesso em: 01 ago. 2014.

Comic layout tutorial: comic balloons and clarity. ChrisOatley.com, jun. 2012. Disponível em: <http://chrisoatley.com/comic-balloons-comic-layout/>. Acesso em: 01 ago. 2014.

PICCOLO, R. The Lost Art Of Not Using A Font. Tina's Groove, 2 ago. 2012. Disponível: <http://tinasgroove.com/2012/08/02/the-lost-art-of-not-using-a-font/>. Acesso: mai. 2015.

PIEKOS, N. Comic book grammar \& tradition by Nate Piekos. Blambot, 2013. Disponível em: <http://www.blambot.com/grammar.shtml>. Acesso em: 29 jul. 2014.

REED, R. Ira Schnapp: the visionary. Dial B for Blog, set. 2006. Disponível em: < http://www.dialbforblog.com/archives/372/>. Acesso em: 31 jul. 2014.

ROSNAY, J. P. Kapow! The language of comics. Oxford dictionaries: language matters, 23 mai. 2012. Disponível em: <http://blog.oxforddictionaries.com/2012/05/the-language-of-comics/>. Acesso em: 30 jul. 2014.

STEWART, B. Wroten on the wind. Potrzebie, 8 set. 2011. Disponivel em: <http://potrzebie.blogspot.com.br/2011/09/wroten-on-wind.html>. Acesso em: abr. 2015.

STEWART-ROBERTSON, T. World's first comic book from Glasgow in spotlight. The Scotsman: Scotland on Sunday, Edimburgo, 24 jun. 2013. Disponível em: <http:// www.scotsman.com/lifestyle/books/world-s-first-comic-book-from-glasgow-in-spotlight-1-2974087>. Acesso em: 31 jul. 2014. 
STRINGER, L. The myth of the speech balloon. Blimey!, 26 mar. 2012. Disponivel em: $<$ http://lewstringer.blogspot.com.br/2012/03/myth-of-speech-balloon.html>. Acesso em: 29 jul. 2014.

\section{Referências das figuras}

BLACKBEARD, B.; WILLIAMS, M. The Smithsonian Collection of Newspaper Comics. Washington (EUA): Smithsonian Books, 1978. 336 p.

BROWNE, C. Hagar the Horrible. Nova lorque (EUA): King Features, 1999.

- O melhor de Hagar, o Horrível. Porto Alegre: L\&PM, 2010. 86 p. (Coleção L\&PM Pocket, v. 80)

CHAN, M. The ravages of time. Taipei (ZH): Tong Li, 2001. 190 p.

CLAMP. Magic Knight Rayearth. Tóquio (JP): Kodansha, 1994. 210 p. (Coleção Magic Knight Rayearth, v. 2)

CRUMB, R. et al. Zap Comix. 2a ed. São Paulo: Conrad, 2005. 187 p.

—. et al. Zap Comix \#13. São Francisco (EUA): Last Gasp, 1994. 50 p.

DITKO, S. GLANZMAN, D. C. Blue Beetle: bugs the squids. Connecticut (EUA): Charlton Comics, 1967. 18 p. (Coleção Blue Beetle, v. 1, nº 1)

EISNER, W. A contract with God and other tenement stories. Nova lorque (EUA): DC Comics, 2000.

—. City people notebook. Nova Iorque (EUA): DC Comics, ago. 2000. 86 p.

- Nova York: a vida na cidade grande. São Paulo: Quadrinhos na Cia, 2009. $440 \mathrm{p}$.

—. The Spirit. Nova Iorque (EUA): Quality Comics, 1950. (Coleção The Spirit, v. 22)

ELLIS, W.; GRANOV, A. The Invincible Iron Man: Extremis. Nova Iorque (EUA): Marvel Comics, 2005. (Coleção Iron Man, nº 01) 
GAIMAN, N. Sandman: Season of Mists. Nova Iorque (EUA): DC Comics, 1990-1991. (Coleção Sandman, nos 21 a 28)

___. 1602. Nova Iorque (EUA): Marvel, 2003. (Coleção 1602, v. 1, nº 1)

GOSCINNY, R. UDERZO, A. Astérix et le devin. Paris (FR): Dargaud, 1972.

. 1961. Le tour de Gaule. Paris (FR): Dargaud, 1965.

GREEN, S.; STERBAKOV, H.; MITCHELL, S. Freshmen: Summer vacation special. Los Angeles (EUA): Top Cow, 2008. 38 p. (Coleção Freshmen, v. 01)

KATAGIRI, I.; NINOMIYA, A. Are you Alice?. Tóquio (JP): Ichijinsha, 2009. (Coleção Are you Alice?, v. 01)

KATSURA, Y. Air. Tóquio (JP): Kadokawa Shoten, 2005. 171 p.

MARZ, R. et al. Witchblade Borne Again: Part One. Califórnia (EUA): Image Comics, out. 2013. (Coleção Witchblade, $n^{\circ}$ 170)

MCLACHLAN, B. Meta Comics. Disponível em: <http://www.brianmcl.com/meta-comics/>. Acesso em: 10 out. 2014.

MILLER, F. Sin City: the Hard Goodbye. Oregon (EUA): Dark Horse Presents, 1991. 8 p. (Coleção Sin City, $n^{\circ}$ 6)

MILLER, F. JANSON, K. Elektra Magazine. Nova lorque (EUA): Marvel Comics, 1996. (Coleção Elektra Magazine, v. 1, n²)

MOULTON, C. Wonder Woman. Nova Iorque (EUA): Wonder Woman Publishing Co., 1944. (Coleção Wonder Woman, $\mathrm{n}^{\circ}$ 10)

O'MALLEY, B. L. Scott Pilgrim and the infinite sadness. Oregon (EUA): Oni Press, 2006. (Coleção Scott Pilgrim, v. 3)

- Scott Pilgrim gets it together. Oregon (EUA): Oni Press, 2007. (Coleção Scott Pilgrim, v. 4)

O'NEIL, D.; COWAN, D. The Question. Nova Iorque (EUA): DC Comics, 1990. (Coleção The Question Quarterly, v. 1)

__.; GOLDEN, M. Batman: o Vale do Morcego Branco. Batman, São Paulo, Edito- 
ra Abril, n², p. 62-81, ago. 1984.

QUINROSE; FUJIMARU, M. Heart no Kuni no Alice. Tóquio (JP): Ishijinsha, 2011. (Coleção Heart no Kuni no Alice, $n^{\circ} 1$ )

SEELEY, T. et al. Witchblade Absolute Corruption: Conclusion. Califórnia (EUA): Image Comics, set. 2013. (Coleção Witchblade, $n^{\circ}$ 169)

SIEGEL, J.; SCHUSTER, J. Superman. Action Comics, Nova Iorque, n. 6, p. 1-12, set. 1943.

SIM, D. Cerebus Jaka's Story \#23. Ontario (CA): Aardvark-Vanaheim, jul. 1990. (Coleção Cerebus, $n^{\circ} 136$ )

- Cerebus Latter Days \#27. Ontario (CA): Aardvark-Vanaheim, jul. 2003. (Coleção Cerebus, $n^{\circ}$ 292)

SOUSA, M. Almanaque do Cebolinha. São Paulo: Panini Comics, jan. 2014. 82 p. (nº 43)

Cebolinha. São Paulo: Panini Comics, jan. 2013. 66 p. (Coleção Histórica Turma da Mônica, n³3)

Mônica. São Paulo: Panini Comics, jan. 2013. 66 p. (Coleção Histórica Turma da Mônica, n 33)

STARKINGS, R.; LOEB, J.; CHURCHIL, I. Ivory Towers: jungle to the zoo. Elephantmen: the Pilot, Berkerley (EUA), Image Comics, v. 1, mai. 2007. (Coleção Hip Flask: Glade Runner, parte 4)

TEZUKA, O. Manga Kyoushitsu. Tóquio (JP): Shogakukan, 2010. 174 p.

THOMPSON, C. Habibi. Nova Iorque (EUA): Pantheon, 2011. 672 p.

Habibi. 672 p. São Paulo: Quadrinhos na Cia, 2012. 672 p.

TORIYAMA, A. Dragon Ball. Tóquio (JP): Shueisha, 2002. 229 p. (Coleção Dragon Ball, v. 01)

TRONDHEIM, L. A.L.I.E.E.E.N. Nova Iorque (EUA): First Second, 2006. 96 p.

VAN LENTE, F.; SILVA, R. B. Brain Boy: Psy vs. Psy. Nova lorque (EUA): Dark Horse 
Comics, 2013. 29 p. (Coleção Brain Boy, volume 1)

WATSUKI, N. Rurouni Kenshin. Tóquio (JP): Shueisha, 2006. 243 p. (Coleção Rurouni Kenshin, $n^{\circ}$ 1)

YERI, N. Peter Panda. Seul (KO): Daiwon, 2005. 187 p. (Coleção Peter Panda, v. 1) 


\section{APÊNDICE A - Questionário respondido por Troy Peteri}

1. What motivated you to be a letterer? Have you worked with text design before?

TP: I actually stumbled across the job accidentally! My degree is in Graphic Design, which is still what I consider lettering to be, and I met Richard Starkings at a convention shortly after I graduated. I showed him my portfolio and was willing to move to Los Angeles to be a production assistant at Comicraft. A position opened as soon as I got to Comicraft and I was taught how to do the job by guys like Wes Abbott and Dave Lanphear, along with Richard himself, obviously. I took to it right away and immediately enjoyed it. As far as working with text design, I had only done it in college classes, but always enjoyed it.

2. According to Richard Starkings, readers notice lettering more when it is poorly designed. From your point of view, what is bad lettering and what are the key features for good lettering?

TP: I agree completely with Rich regarding bad lettering. Although the difference between bad and good can be pretty subtle. Bad lettering usually just LOOKS amateur. Meaning: sloppy balloon placements that have no regard for the artwork itself or the flow of the words on the page, word balloons and balloon tails that look like they're the same one cut and pasted over and over, rather than any individuality, and poor font choices that often look generic. Good lettering should be very easy for the reader to understand and it should cause their eyes to quickly and easily move across the page with no confusion or re-reading necessary. Things like cool word balloons and interesting fonts that work well with the subject mater, as well as professional-looking sound effects and captions and such.

3. What would you consider as the basic assignments for a letterer?

TP: I would say the basic assignments for a letterer are to make the page as easily readable and attractive to the eye as possible while leaving the artwork and text itself to tell the story. Each page is basically a graphic design assignment mixed with traditional illustration.

4. Throughout a project, how is your communication with the others involved in the comics' creation, like the writer and the artist?

TP: I don't know how it is with other letterers, but I have a lot of contact with the writer and editor, and less contact with the artist. Not for any specific reason, but I would very rarely contact the artist regarding lettering-related things, unless there's something that's really not clear in the art.

5. Your job involves bringing sounds to the visual field, so you have to deal with 
two different senses. How do you associate a font with the sound you want to transmit?

TP: Although I do draw some sound effects "by hand," I'm usually using existing fonts for the individual effects. And l'll choose those fonts based on what sound is being conveyed. After dealing with them for so many years, it just becomes second nature. And some of it is very obvious. If it's a gross, squishy sound, you're gonna use a gross, squishy-looking font, if it's a solid, violent $\mathrm{CRUNCH}$, you're gonna use something blocky and strong-looking, etc.

6. In the latest issues of Witchblade, how did you come up with the new lettering style?

TP: The current Witchblade artist, Laura Braga, is a really talented artist whose style, to me, looks very organic and naturalistic. I'm already a huge fan of her stuff. And I like to change the lettering style to fit the book whenever there's a major regime change in the book, or a relaunch, or whatnot. Since her style is so organic, I wanted to use a font that looks like a person's handwriting and I wanted to individually "draw" each word balloon so it doesn't look like each balloon is merely a cut and pasted perfect circle/oval. And ideally the sound effects will reflect the same sensibility.

7. What is your opinion regarding the long lasting debate about hand versus computer lettering?

TP: I understand everyone's nostalgia for hand lettering, but long ago it simply became a matter of practicality. It takes virtually no time to do corrections/edits via computer lettering, whereas with hand lettering you would need to re-write, re-draw and re-paste a balloon whenever there was the slightest last second decision. Many artists and creators and readers love the IDEA of hand-lettering on the board, but it wold really need to be a special case for it to be done. Richard Starkings never uses the term "hand lettering," he calls it "pen lettering," because "we still use our hands" when we're on a computer! I also think there are enough methods and "cheats" that you can replicate hand lettering ON a computer. (Not to mention the fact you can letter exponentially faster via computer.)

8. How does lettering contribute to storytelling in comics?

TP: A comparison that is often made is to that o special FX in movies. We've become so accustomed to massive amounts of special FX in movies that it takes a lot to impress or wow someone, but if you have some shoddy CGI or clunky FX, a viewer notices right away and it takes them outta the movie. The same can be said with hastily done, often cheap, lettering. If you see a page of art with beautiful art that is covered up by generic, ugly lettering, it takes you outta the book. And affects your enjoyment of the art. Ultimately, the letterer's job is to 
serve the writer, artist and reader (not necessarily in that order!) and to do so, the letterer needs to tell the story using his/her placement of the text and decision-making process regarding fonts, sound effects, etc. There are MANY great examples, but l'd say Sandman, Batman: Year One and Arkham Asylum are all cool examples of how letetring helps the actual storytelling within a story that is already great. 


\section{APÊNDICE B - Questionário respondido por Todd Klein}

1. You've described comics lettering as putting the writer's words into the artist's pictures. It is a simple explanation, but it is actually an intrinsic task that involves other duties, such as using appropriate balloons and placing them on the page. What else would you consider as assignments for your job?

TK: The letterer's job consists of creating everything on the comics page that's made of words, except for anything the artist has drawn that works well. Lettering must be accurate, readable and placed correctly to read well and in the correct order. Beyond that a good letterer can add creative and stylistic touches that enhance the finished product.

2. According to Richard Starkings, readers notice lettering more when it is poorly designed. From your point of view, what is a bad lettering and what are the key features of a good lettering?

TK: Any time lettering interferes with the reader's ability to comprehend and enjoy the story it's bad. Aspects of good lettering are in the previous answer.

3. How does lettering contribute to storytelling in comics?

TK: In a variety of ways, but mainly by conveying the writer's words.

4. Throughout a project, how is your communication with the others involved in the comics' creation, like the writer and the artist?

TK: It varies greatly from close involvement to none, depending on the project.

5. Your job involves bringing sounds to the visual field, so you have to deal with two senses. How do you associate a font with the sound you want to transmit?

TK: This is something that comes with experience and knowledge of what's been done before, I can't really explain it.

6. In the Sandman series, some characters have their own design styles for their lines, which suit to their personalities. How was the process of defining these styles?

TK: Again, this is not something I can explain, except in a few cases where Neil had specific ideas. It's part of the creative process.

7. Concerning the methods, it's written in your book that you were resistant to computer lettering at first. What benefits did the computer introduce so that you changed your mind in 1994 ?

TK: I saw it was the way things would go in the future, it made things easier for the publishers. Once I began using it myself, I found it also saved me a lot of time. 


\section{APÉNDICE C - Questionário respondido por Lilian Mitsunaga}

1. Encontrar seu nome nos mais variados títulos de $\mathrm{HQ}$ publicados aqui no Brasil é tão fácil que alguns fãs já a consideram uma lenda viva. Como foi sua trajetória até se estabelecer no mercado e obter esse renome? O que a motivou a entrar para esse ramo?

LM: Muitos fatores contribuíram para que eu ingressasse nesse mundo. Tenho uma irmã três anos mais velha que me ensinou a ler quando eu tinha 4 anos. Ela ia à escola e, na volta, me ensinava tudo o que havia aprendido. Assim, eu tinha paixão por leitura e lia tudo o que caísse em minhas mãos. Livros de histórias e gibis eram meus favoritos. Lia Irmãos Grimm, Disney, Maurício e heróis.

Aliado a isso, sempre gostei de desenhar e acabei entrando na faculdade de arquitetura, período integral. Apesar de a faculdade ser gratuita, eu não queria sobrecarregar meus pais e queria trabalhar, mas era complicado porque eu morava longe de São Paulo e gastava, diariamente, de quatro a seis horas no transporte. Então soube que a Editora Abril tinha horário maleável para o pessoal que trabalhava com quadrinhos e fui tentar a sorte.

$\mathrm{Na}$ época, as letras eram feitas à mão, com nanquim. Eu sempre tive uma letra razoável, fiz algumas amostras e fui com a cara e a coragem. Eles gostaram do meu teste e investiram em mim durante três meses, me passando dicas para melhorar minha performance; e então fui contratada.

Mesmo com o diploma de arquiteta na mão, eu já havia sido fisgada pelo mundo dos quadrinhos definitivamente. Trabalhei com letras à mão por 18 anos até a chegada do computador nessa área, na década de 1990. Comecei fazendo quadrinhos Disney, tanto material traduzido de fora (EUA, Itália, França e Dinamarca) quanto artes produzidas por artistas brasileiros. Logo fui adquirindo prática e velocidade.

As redações Disney e heróis dividiam o mesmo andar e, com a inclusão de mais títulos na seção de heróis, fui convidada para fazer letras para os heróis. Como na redação de heróis era comum dar crédito para as pessoas que trabaIhavam na versão nacional, meu nome e dos coloristas começaram a aparecer ao lado dos nomes dos artistas estrangeiros. Esse detalhe foi importantíssimo para que muitas pessoas passassem a me "conhecer".

Cumprir prazos era uma coisa muito importante e tenho orgulho de dizer que nunca perdi um prazo sequer nesses anos todos em que trabalho na área. Acho que isso foi um dos fatores para que as pessoas me procurassem para trabalhar nas publicações. Claro que sempre procurei caprichar nos trabalhos. Rapidez, qualidade e pontualidade foram preponderantes para me firmar no mercado e me tornar conhecida. 
2. Embora esteja presente em quase toda publicação, o ofício de trabalhar com as letras ainda é pouco conhecido. Quais são as atribuições de um letreirista/ letrista? Elas variam de acordo com a editora?

LM: Sim, as atribuições de um letrista variam de acordo com a editora. No caso da Abril, éramos responsáveis pelas letras dos balões e onomatopeias, que eram todas traduzidas, no caso do material estrangeiro. As artes eram remontadas para se encaixar no formato das publicações nacionais e recolorizadas com a paleta de cores usada na época, que era bastante restrita. Com o tempo, passamos a cuidar dos títulos também. Outras editoras preferiam não mexer na arte e só modificavam o que tivesse fundo branco ou chapado, porque era mais fácil de se retocar.

Antes dos computadores, compravam-se fotolitos com quadricomia (preto, azul, amarelo e vermelho) e era muito complicado o retoque. O mais usual era adicionar uma camada extra de preto com as letras, para não onerar a publicação. No caso das artes nacionais, alguns artistas preferiam desenhar as onomatopeias, fazendo com que ela fizesse parte da cena. Outros deixavam que qualquer coisa que envolvesse tipologia a cargo dos letristas: balões, título, créditos, onomatopeias, placas, etc.

As atribuições continuam as mesmas: letras nos balões, onomatopeias e títulos. Mas, se tiver tendência às artes, muitos retoques acabam fazendo parte do pacote. Ou seja, quanto mais polivalente um letrista puder ser, melhor para otimizar o processo. Dependendo da editora, toda a publicação passa a ser responsabilidade do letrista, como a diagramação das páginas iniciais e finais. Algumas preferem fazer isso internamente, como expediente, página de créditos, etc.

Antes, aplicávamos as letras, balões e onomatopeias diretamente na página desenhada. Hoje isso praticamente não existe. Recebemos as páginas escaneadas e tudo é aplicado digitalmente em layers. Para agilizar o processo, é possível letreirar em cima das artes a lápis. Ganha-se tempo, porque, enquanto as páginas são arte-finalizadas e colorizadas, as letras podem ser feitas ao mesmo tempo, possibilitando o envio das páginas para a revisão.

3. Letreirar é uma das etapas da criação de HQs, havendo ainda a parte de criar a história, desenhá-la, entre outras. Como é sua relação de trabalho com os demais envolvidos no processo (escritor, desenhista, editor)?

LM: Algumas editoras fazem reuniões para determinar o que deve ser feito, outras pedem que seja o mais parecido possível com a obra original (no caso de obras traduzidas). Hoje minha relação se restringe à troca de e-mails. Ficou muito prático e é uma tendência neste mundo sem tempo em que vivemos. Geralmente o primeiro contato é feito por meio de reuniões, mas, depois, e-mails, skype ou telefone são os meios mais utilizados, mesmo porque algumas pessoas para quem presto serviços se encontram em outros estados do Brasil e a 
logística de se fazer reuniões se torna muito mais difícil.

4. Dependendo da equipe com que se trabalha, a tarefa de letreirar pode enfrentar alguns obstáculos, como a falta de espaço deixado pelo artista ou o volume de texto pedido pelo escritor. Na sua opinião, que fatores mais comprometem a feitura do letreiramento com qualidade? E quais valorizam-na?

LM: Um texto muito longo, quando não há espaço suficiente para diagramá-lo, é um fator que compromete a beleza da página. Outra dificuldade que o letrista encontra é a ordem de leitura dos balões. Muitas vezes, a pessoa que fala primeiro na cena está na extrema direita da página. Daí, temos que fazer uma seta muito comprida, que atravessa a página toda, porque a ordem de leitura é sempre da esquerda para a direita. Esse é o pior problema. Quando o artista tem essa sensibilidade na hora de criar, acho que valoriza muito a página final. É um trabalho de equipe. Um bom copidesque também salva as situações críticas.

5. Você não se limita às fontes comerciais e cria algumas específicas para determinadas obras, certo? Nesses casos, como é feita a escolha do desenho da letra?

LM: Muitas fontes que crio são baseadas nas próprias letras dos autores. Isso cria uma identidade com a obra. Como algumas editoras pedem que as fontes sejam parecidas com as obras originais e, por vezes, elas foram letreiradas à mão, fica muito mais fácil digitalizar a grafia do autor e usar como base.

6. Letreirar implica sonorizar uma história através de aspectos visuais. Como é possível estabelecer essa associação som-imagem?

LM: Como os quadrinhos são basicamente visuais, não temos o som propriamente dito, mas o letreiramento pode induzir essa sensação. O uso de onomatopeias para ilustrar as cenas com barulhos de explosões, tiros, batidas, socos... é o melhor exemplo disso.

7. De que maneira o letreiramento pode contribuir para o contar uma história?

LM: Complementando a pergunta anterior, além das onomatopeias, é possível utilizar fontes tremidas para dar a ideia de frio ou medo. O tamanho da fonte pode sugerir sussurro ou gritos. Ou ainda pode-se usar variados tipos de fontes para caracterizar um personagem. O desenho dos balões também contribui para o entendimento da histórias. Existem balões de fala normal, pensamento, telepatia, narração, eletrônicos... São recursos muito bons que usamos para passar ao leitor, de imediato, a ideia de um filme sem som; e a imaginação se incumbe de fazer o resto. 
8. Seu trabalho é visto tanto em obras nacionais quanto em obras estrangeiras traduzidas. Quais as diferenças entre reletreirar uma história e letreirá-la pela primeira vez?

LM: Letreirar uma $\mathrm{HQ}$ traduzida, em tese, requer menos tempo, uma vez que não é necessário desenhar os balões. Porém... muitas vezes, são necessários tantos retoques na arte para aplicar as onomatopeias traduzidas (ou placas) que é difícil afirmar que é mais fácil. Partir do zero sempre demanda um pouco mais de tempo, tem que se entrar em acordo com o artista, escolher o tipo de fonte que melhor se encaixe na obra, tipo de balão, formato, cores e tamanho.

Eu diria que a palavra que melhor expressa as diferenças é: "depende". Tudo depende de cada obra.

9. O uso do computador para agilizar o processo não é novidade, mas ainda persiste o embate do letreiramento digital contra o manual. Qual você prefere e por quê?

LM: Novamente a palavra "depende" se aplica aqui. Hoje em dia, pode-se fazer praticamente tudo digitalmente. Mas existem algumas coisas que são mais rápidas à mão. Textos em curvas aleatórias e diversos tipos de tamanhos de fontes na mesma frase (como os balões da personagem Delírio, do Sandman) são mais rápidos de se fazer à mão.

Hoje prefiro fazer tudo digitalmente. É mais prático, mais limpo e mais fácil de corrigir. Prático porque podemos usar como base as artes ainda nos esboços, não é necessário ter a arte pronta. Não é preciso se deslocar fisicamente para buscar ou entregar as artes, podemos usar e-mail, servidores FTP e outros sites de transferências de dados. Limpo porque, depois de 18 anos lidando com tinta nanquim, canetas entupidas, penas que quebravam e muitos calos nos dedos, usar um computador é muito bom. Claro que todo processo tem seus inconvenientes, mas gostei da tecnologia nessa área. E a facilidade de correção é um bênção... mas também uma maldição! [risos] Porque, por ser mais fácil de corrigir, algumas pessoas não ficam contentes nunca e sempre querem alterar alguma coisa... mesmo que a obra esteja na gráfica. 


\section{APÉNDICE D - Questionário respondido por Nate Piekos}

1. What motivated you to be a letterer? Did you have it in mind when you entered Design College?

NP: Not at all. My design degree focused on corporate identity (logo) design, and I took some typography classes while I was there, but a career in comics didn't seem likely.

2. What would you consider as the basic assignments for a letterer?

NP: Lettering, title and credits design, interpretation of a script as it relates to the special rules of comics lettering, and for the most design-experienced letterers, production, logo, and font design.

3. According to Richard Starkings, readers notice lettering more when it is poorly designed. From your point of view, what is bad lettering and what are the key features for good lettering?

NP: Bad lettering is usually full of amateur mistakes. Comics has a plethora of its own unique punctuation/grammar rules (http://www.blambot.com/grammar. shtml) and bad letterers disregard them, or are ignorant of them. A good letterer is a good graphic designer at heart. That's the real difference. Almost anyone can buy a font and do a mediocre lettering job. But when you've got an experienced eye and a real love for *design*, that's when lettering is at its best.

4. Your job involves bringing sounds to the visual field, so you have to deal with two different senses. How do you associate a font with the sound you want to transmit?

NP: Soft, wet sounds, tend to have soft, wet font choices. Scary monsters tend to have rough, crooked font choices. It's mostly common sense -- but when I start a new series, I decide on a particular stable of fonts to use throughout. It's part of what I call a lettering style guide. All the fonts must compliment the art, and create a visual style FOR that series. I don't pick fonts haphazardly page by page. I know ahead of time that if splashing water comes up, I'll use font $X$ for it in this series.

5. Throughout a project, how is your communication with the others involved in the comics' creation, like the writer and the artist?

NP: Almost always through email, unless we happen to meet up at a convention. I deal mostly with the editors, as they are the intermediary between all of us. But I've worked with so many different writers and artists now, that we do email back and forth with particular concerns or questions. 
6. In Atland, in addition to being the letterer, you're also the writer and the artist. What precautions do you take in writing the script and drawing so that the lettering's quality is enhanced?

NP: Mostly space constraints! It's very common for an artist to not leave enough room for the lettering. When I'm doing all the chores, I have control over that.

7. How did you come up with the idea of starting an online type foundry?

NP: A friend of mine mailed me a book on HTML, so I was reading that while I was doing corporate identity design.

8. Blambot is specialized in typefaces for comics. What makes comic fonts different from other fonts?

NP: Most of the time it's the organic-ness of the designs. Comics lettering has its own aesthetic. It's specialized a lot like architect and engineering lettering. It's also hard to describe! But there's a huge difference between what the average person thinks is comic lettering (Which is usually overly-cute, and child-like) and what actual comic book lettering looks like. Non-comic readers think comic lettering is like the old 60s BATMAN TV show.

9. What is your opinion regarding the long lasting debate about hand versus computer lettering?

NP: That's like the difference between acoustic and electric guitar playing. It's basically the same thing, with different equipment. The big difference is the learning curve. Hand letterers spent much more time developing a sense of graphic design early on, and an individual style, early on -- before they could ever even start lettering. The amateur digital letterer has a shorter "gestation" period before their work is seen, and less chance to develop the graphic design sensibilities that mean the difference between a mediocre letterer and a good one.

10. How does lettering contribute to storytelling in comics?

NP: You can tell a story without words, but lettering adds a system of more concise information delivered to the reader -- sometimes without them even realizing it. Sadly, I think bad lettering has more of an impact on storytelling than good lettering. When it's good, you barely notice it, like the soundtrack and sound effects in a movie -- it conveys mood without you really realizing its effect. When it's bad, it snaps you right out of the story. The worst crime a letterer can commit. 


\section{APÉNDICE E - Questionário respondido por Ron Marz}

1. How is the work relationship between the writer and the letterer? Throughout a project, how is your communication with him/her?

RM: I'm usually in pretty close contact with the letterer. On creator-owned work, as well as the Edgar Rice Burroughs strips and a number of other projects, I'm the first person who sees the lettering, so we can make any revisions/corrections. We swap pages back and forth before getting anything ready for print.

2. How does lettering contribute to storytelling in comics?

RM: Good lettering can make or break a comic. It's the final piece to the creative mix, and it has to be right in order for the comic to be successful. Bad lettering on an otherwise professional comic just ruins the whole thing. You don't notice good lettering, per se, it just flows with the story. But bad lettering can pull you right out of the story.

3. What are the criteria used to select an appropriate professional to insert the text in your work?

RM: I work mostly with Troy Peteri, who has been lettering my stuff since CrossGen more than 10 years ago. He knows what I'm looking for, I know what he does, so it's a really good partnership. I'm pretty fussy about lettering, so I tend to ask for Troy on everything I can. It streamlines the process.

4. In 2012, you wrote an article to Comic Book Resources with some lessons about writing scripts in a way it helps the letterer. However, there are problems that just cutting the dialogues won't solve. What was the most difficult situation to fix that you have faced?

RM: Nothing that couldn't be solved. It's incumbent on the writer to make things fit, to make sure characters are speaking in the right order. If the artwork is going to force crossed balloon tails or difficult placements, the writer needs to adjust the dialogue. It's part of the job. A comic should be a collaboration, not an assembly line, and that includes the lettering process. 
5. In the latest issues of Witchblade, lettering has gone through some abrupt changes. How did the readers react to this? Do you believe it has succeeded in reflecting the changes in the series?

RM: With the exception of a comment or two, I don't think anyone even noticed, which is a good thing. That means the lettering didn't pull anyone out of the story, it pulled them in. 


\section{APÊNDICE F - QUestionário respondido por sidney GUSMan}

1. Como é a relação de trabalho entre o editor e o letreirista?

SG: É uma etapa da produção de uma HQ. Portanto, precisa receber a mesma atenção das demais.

2. Vários títulos de história em quadrinhos já passaram por suas mãos. Enquanto alguns, como Sandman, contam com profissionais em letreiramento, outros não possuem ninguém especializado para a tarefa, como é o caso de alguns mangás. Isso provoca alguma diferença que afeta seu trabalho como editor?

SG: Na verdade, não. Alguns trabalhos requerem o letreiramento de um profissional especializado porque vários personagens têm "voz" própria ou por terem sido feitas à mão. Mas há HQs em que isso não se faz necessário, e o trabalho acaba sendo feito pelo próprio autor. Cabe ao editor sacar se a letra pode ou não dar um up nas páginas.

3. Em sua opinião, de que maneira um letreirista experiente contribui para a visualização da história?

SG: Como falei acima, as letras indicam como é a "voz" dos personagens. E um letrista pode, sim, indicar para o leitor que este ou aquele personagem falam assim ou assado. E também em casos que o autor estrangeiro fez toda a letra à mão, conferindo muito da sua personalidade ao trabalho. Aí, acho que vale emular o estilo. Uma prova disso foi no álbum Zap Comix, da Conrad, em que a Lilian Mitsunaga deu um show!

4. Quais os critérios usados para designar um letreirista a um determinado projeto?

SG: Cuidado, atenção e, especialmente, criatividade. Um letrista pró-ativo pode colaborar para a fluidez de uma HQ.

5. Foi dito em uma entrevista coletiva que seu trabalho envolve também adaptar textos já traduzidos. As alterações feitas se referem apenas à adequação de linguagem ou preveem também facilitar a colocação do texto na obra?

SG: Hoje não existe mais esse problema, mas durante muito tempo (até o começo dos anos 2000) o editor tinha que se virar pra fazer o texto caber no balão. Aí, em vez de usar um corpo muito menor, é melhor enxugar o texto.

6. $\quad \mathrm{Na}$ Universo $H Q$, em sua seleção dos melhores e piores quadrinhos publicados em cada mês, leva-se em consideração algum critério relativo ao tratamento gráfico dos textos? 
SG: Não. Mas quando é feito algum trabalho que chama a atenção, sempre faço questão de mencionar.

7. O letreiramento é categoria das maiores premiações internacionais de HQs, mas esse ramo foi avaliado apenas uma vez no Brasil, na HQMIX de 1999. Esse ofício vem sendo valorizado desde então, mas nunca voltou a ser premiado. Com seu conhecimento acerca dos quadrinhos nacionais, que motivo você pondera para esse fato? Como você considera a visibilidade do letreiramento atualmente no país?

SG: Isso se deve ao fato de o letreiramento eletrônico ter se expandido de maneira assombrosa. É comum, no meio editorial, acharem que qualquer um pode fazer letras, e não é bem assim. Existe todo um trabalho, desde a escolha das fontes, até a disposição do texto no balão e o uso de onomatopeias. Penso que o Brasil ainda tem muito a evoluir nesse campo, apesar de ter uma profissional do nível da Lilian Mitsunaga. 